Claudia dos Reis e Cunha

\title{
RESTAURAÇÃO:
}

diálogos entre teoria e prática no brasil nas experiências do iphan 
Claudia dos Reis e Cunha

\section{RESTAURAÇÃO: \\ diálogos entre teoria e prática no brasil \\ nas experiências do iphan}

Tese apresentada à Faculdade de Arquitetura e Urbanismo da Universidade de São Paulo, para obtenção do grau de Doutor em Arquitetura e Urbanismo

Área de concentração: História e Fundamentos da Arquitetura e do Urbanismo

Orientadora: Profa. Dra. Beatriz Mugayar Kühl 
AUTORIZO A REPRODUÇÃO E DIVULGAÇÃO TOTAL OU PARCIAL DESTE TRABALHO, POR QUALQUER MEIO CONVENCIONAL OU ELETRÔNICO, PARA FINS DE ESTUDO E PESQUISA, DESDE QUE CITADA A FONTE.

email: claudiareis@usp.br

Catalogação da Publicação

Cunha, Claudia dos Reis e

C972r Restauração: diálogos entre teoria e prática no Brasil nas experiências do IPHAN / Claudia dos Reis e Cunha. --São Paulo, 2010.

171 p. : il.

Tese (Doutorado - Área de Concentração: História e Fundamentos da Arquitetura e do Urbanismo) - FAUUSP.

Orientadora: Beatriz Mugayar Kühl

1.Patrimônio arquitetônico - Preservação - Brasil 2.Patrimônio Cultural - Conservação - Restauração 3.Arquitetura - Restauração Teoria - I.Título 
O presente trabalho foi realizado com apoio do CNPq - Conselho Nacional de Desenvolvimento Científico e Tecnológico I Brasil 
Para Ana Maria 
Ao CNPq pela concessão de bolsa de estudos para realização desta pesquisa com dedicação exclusiva, inclusive durante o estágio no exterior.

À minha orientadora, Profa. Dra. Beatriz Mugayar Kühl, pelo apoio que sempre encontrei em todas as questões acadêmicas e em outras nem tão acadêmicas assim.

Às professoras Dra. Mônica Junqueira de Camargo e Dra. Silvana Rubino, pela atenta leitura e pertinentes observações feitas durante 0 Exame de Qualificação.

Aos professores da FAU-USP: Ana Lucia Duarte Lanna, Fernanda Fernandes, José Eduardo de Assis Lefèvre, José Pedro de Oliveira Costa, José Tavares Correia de Lira, Maria Lucia Bressan Pinheiro e Paulo César Garcez Marins, que permitiram a troca de idéias e induziram reflexões, seja na sala de aula, seja durante o cafezinho.

À Marly Rodrigues, pelas conversas e pelo encorajamento.

Ao Prof. Dr. Giovanni Carbonara, pela supervisão dos estudos em Roma com tamanha generosidade. Também aos professores da Scuola di Specializzazione in Restauro dei Monumenti: Beatrice Vivio, Donatella Fiorani, Maurizio Caperna e Simona Salvo.

Aos funcionários das bibliotecas da FAU-USP, FAU-Maranhão, "Guglielmo De Angelis d'Ossat" do Dipartimento di Storia dell'Architettura, Restauro e Conservazione dei Beni Architettonici / Università "La Sapienza" e do International Centre for the Study of the Preservation and Restoration of Cultural Property (ICCROM).

À minha família, especialmente à minha mãe, com quem posso contar incondicionalmente. Mas também à Neusa, à Raquel, à Sueli, ao José Maria e ao Jorge.

Ao Eron, que agüentou firme todas as minhas ausências, sem jamais desistir do que construímos juntos nesses anos todos.

Ao meu mais assíduo leitor: Edgar, amigo fiel e dedicado de todos os momentos. 
Aos amigos queridos que, hora mais de perto, hora mais de longe, estiveram sempre acompanhando minha trajetória: Raíssa e Alexandre, Nelson, Fernanda, Marcelo, Vanda, Alessandra, Abilio e Silvana, Denise, Ivana, Marco Aurélio, Tânia e Lisandre.

Às companheiras de FAU: Sabrina, Manoela e Roseli, por compartilhar das alegrias e angústias da vida acadêmica.

À Dadá, que fez a Itália menos estrangeira para mim. À Karina e à Paulinha, que tornaram a estada em Roma menos solitária e bem mais divertida. E também à Ligia e à Ana, que me deram um "lar" romano, com direito a casa cheia e almoço em família. 
II misurare la bellezza rispetto alla vecchiaia, e la vecchiaia rispetto alla bellezza, è affare delicato; e ci vogliono buoni occhi, buon criterio, buona esperienza, buona bilancia e molta buona volontà di pesar tutto, anche gli scrupoli, con animo spassionato e disinteressato. La vanità e l'ambizione del restauratore diventano anche più funeste al monumento di quello che possono riuscire l'avidità e l'avarizia. Camillo Boito [Questioni pratiche di Belli Arti, 1893] 
Esta pesquisa tem por objetivo central aprofundar 0 debate a respeito das questões teóricas que deveriam guiar as ações práticas de intervenção que visam à preservação dos bens culturais no Brasil. Não se trata de discutir as formulações teóricas com finalidade em si mesmas, mas de refletir sobre a necessidade de um efetivo intercâmbio entre teoria e prática para que a preservação seja um fato concreto, tanto no que se refere a edificações isoladas quanto a conjuntos urbanos. Com esta finalidade, analisa a atuação do Instituto do Patrimônio Histórico e Artístico Nacional (IPHAN) ao longo de seus mais de setenta anos de trajetória, servindo-se de algumas intervenções em bens culturais que exemplificam as formas de aplicação (ou não) dos preceitos teóricos na prática preservacionista brasileira - a qual exige restaurações fundamentadas para preservar os bens como documentos fidedignos que sirvam como efetivos suportes materiais da memória coletiva. No Brasil, após uma releitura crítica das intervenções feitas durante a chamada "fase heróica" do SPHAN, novos parâmetros são propostos no âmbito das práticas de preservação, principalmente no tocante ao que se entende por patrimônio, aos critérios de seleção para os tombamentos e à descentralização da tutela dos bens culturais; a memória e suas diferentes formas de manifestação e seus múltiplos suportes também são incorporados ao discurso preservacionista local. A par dessas novas discussões, verificam-se referências recorrentes a textos teóricos da restauração - tais como a Carta de Veneza ou a Teoria da Restauração de Cesare Brandi -, as quais, entretanto, denotam um conhecimento superficial, quando não equivocado, dos princípios estabelecidos naqueles escritos, permanecendo como regra nas intervenções o empirismo ou a negligência. Diante de tal quadro, a hipótese proposta para construção desta Tese é a da aplicabilidade das formulações teóricas da restauração à realidade brasileira atual, demonstrando os severos prejuízos a uma verdadeira ação preservacionista acarretados pela cisão entre teoria e prática no âmbito da restauração.

Palavras-chave: Arquitetura (restauração; teoria); Patrimônio arquitetônico (Preservação) - Brasil; Patrimônio cultural (conservação; restauração) 
The main objective of this research is to deepen the debate on theoretical questions which should guide the practical interventions aiming at the preservation of cultural goods in Brazil. It is not the point of this work to discuss the theoretical formulations in itself, but to reflect on the necessity of an effective exchange between theory and practice in order that preservation be a concrete fact, both with respect to isolated buildings as well as urban complexes. With this purpose, the actions of the Instituto do Patrimônio Histórico e Artístico Nacional (IPHAN) are evaluated through its more than seventy years trajectory, taking some interventions in cultural properties as examples of the application (or not) of theoretical principles in Brazilian preservationist practice - which demands theoretically grounded restorations to preserve the goods as faithful documents serving as effective material support of the collective memory. In Brazil, after a period of critical analysis of interventions performed during the so-called "heroic phase" of SPHAN, new parameters are suggested in the realm of preservation practice, mainly with respect to what is understood as heritage, to the selection criteria to list a building, and to the decentralization of the guardianship of the cultural goods; the memory and its different forms of manifestation and varied supports are also incorporated in the local preservationist discourse. These new discussions involve recurrent references to theoretical texts in restoration - such as the Venice Charter or the Theory of Restoration of Cesare Brandi -, which, however, denote superficial knowledge, when not mistaken, of the principles established in those writings, being a rule in the interventions either empirism or negligence. In face of this, the hypothesis proposed for this Thesis is that of the applicability of the theoretical formulations in restoration to the present Brazilian reality, displaying the severe loss brought to a real preservationist action by the split between theory and practice in the realm of restoration.

Key-words: Architecture (restoration; theory); Architectonic heritage (preservation) - Brazil; Cultural heritage (conservation; restoration) 
LISTA DE SIGLAS

BID Banco Interamericano de Desenvolvimento

BNDES Banco Nacional de Desenvolvimento Econômico e Social

BNH Banco Nacional de Habitação

CEF Caixa Econômica Federal

CIAM Congrès Intemational d'Architecture Modeme

CNRC Centro Nacional de Referência Cultural

CONDEPHAAT Conselho de Defesa do Patrimônio Histórico, Arqueológico, Artístico e Turístico

DET/IPHAN Divisão de Estudos e Tombamentos do IPHAN

DPHAN Diretoria do Patrimônio Histórico e Artístico Nacional

FAU-USP Faculdade de Arquitetura e Urbanismo da Universidade de São Paulo

FCPSHO Fundação Centro de Presenvação dos Sítios Históricos de Olinda

FICART Fundos de Investimento Cultural e Artístico

FNC Fundo Nacional de Cultura

FNPM Fundação Nacional Pró-Memória

IBPC Instituto Brasileiro do Patrimônio Cultural

ICCROM International Centre for the Study of the Preservation and Restoration of Cultural Property

ICOMOS International Council on Monuments and Sites

ICR Istituto Centrale per il Restauro

IPEA Instituto de Planejamento Econômico e Social

IPHAN Instituto do Patrimônio Histórico e Artístico Nacional

MARS Group Modern Architectural Research Group

MEC Ministério de Educação e Cultura

MES Ministério da Educação e Saúde Pública

MIC Ministério da Indústria e Comércio

MinC Ministério da Cultura

MRE Ministérios das Relações Exteriores

PCH Programa Integrado de Reconstrução das Cidades Históricas

PRONAC Programa Nacional de Apoio à Cultura

SEMOR Secretaria de Modemização e Reforma Administrativa 
SPAB Society for the Protection of Ancient Buildings

SPAN Senviço do Patrimônio Artístico Nacional

SPHAN Senviço do Patrimônio Histórico e Artístico Nacional

SPHAN Secretaria do Patrimônio Histórico e Artístico Nacional

UNESCO United Nations Educational, Scientific and Cultural Organization 
INTRODUÇÃO 14

PARTE I: RESTAURO E RESTAUROS

1-DEFINIÇÕES NECESSÁRIAS 21

1.1 - restauração: busca de uma conceituação possivel 21

1.2 - restauração arquitetônica e urbanística: categorias a parte? 37

1.3 - restauração $X$ conservação 43

1.4 - restauração: diversidade de meios e convergência de fins 51

1.5 - restauração: projeto e uso 58

PARTE II: O IPHANE O RESTAURO:

PRÁTICAS DE INTERVENÇÃO X FORMULAÇÕES TEÓRICAS

2-RESTAURAÇÃO NA FASE HERÓICA DO IPHAN (1937-1968) 62

3-RESTAURAÇÃO NA FASE MODERNA DO IPHAN (1968-1990) 87

4-RESTAURAÇÃO NO IPHAN DE HOJE (1990-ATUAL) 122

CONSIDERAÇÕES FINAIS 155

REFERÊNCIAS BIBLIOGRÁFICAS 161 


\title{
-INTRODUÇÃO
}

\author{
O que se delineia no presente e no futuro imediato não é de \\ maneira alguma uma oposição entre uma vontade de \\ conservação e uma vontade de renovação. É inevitável que \\ tudo se renove [...]. Todavia, o novo deve-se produzir-se \\ segundo metodologias científicas e o velho deve ser \\ conservado segundo metodologias científicas. Portanto, 0 \\ debate não é entre velho e novo, nem tampouco entre \\ pessoas que gostam do velho e pessoas que gostam do \\ novo, mas entre duas disciplinas cujas diferenças \\ metodológicas sempre poderão resolver-se no plano dialético. \\ Giulio Carlo Argan [A arte no contexto da cultura moderna, 1979]
}

Recentemente foram comemorados os 70 anos de criação do primeiro órgão brasileiro responsável pela preservação de nosso patrimônio cultural: 0 então Serviço do Patrimônio Histórico e Artístico Nacional - SPHAN, hoje Instituto do Patrimônio Histórico e Artístico Nacional - IPHAN. Ao longo dessas mais de sete décadas de construção de um corpus patrimonial no Brasil percebe-se 0 crescente interesse que a área vem ocupando na sociedade: a preservação do patrimônio em suas diversas acepções e com diferentes adjetivos - arquitetônico, urbano, ambiental, cultural, imaterial ou intangível, biológico ou genético -, vem ganhando espaço entre um público cada vez mais amplo e em diferentes meios.

Fenômeno de escala mundial, a preservação do patrimônio cultural ganha contornos cada dia menos precisos, tendo em vista a ampliação dos objetos patrimoniais e, na mesma medida, dos campos disciplinares envolvidos em seu estudo e divulgação. David Lowenthal sustenta que se trate de uma verdadeira "cruzada" patrimonial no seio da sociedade ocidental. ${ }^{1}$ E não é sem razão. Numa rápida retrospectiva, nota-se que desde a década de 1960 há um movimento no sentido de ampliar aquilo que se entende por patrimônio, que passa a incorporar bens de tipologias mais diversas e de períodos mais recentes, paralelamente à sua expansão geográfica, alcançando hoje em dia rincões os mais distantes. "Fala-se de um patrimônio não só histórico, artístico ou arqueológico, mas ainda etnológico, biológico ou natural; não só material,

1 LOWENTHAL, David. The heritage crusade and the spoils of History. Cambridge: Cambridge University Press, 1998. 
mas imaterial; não só local, regional ou nacional, mas mundial". "É a patrimonialização da vida, que se vê assaltada pela rápida transformação e pela ameaça de massificação, imposta pelo mundo globalizado, impelindo as sociedades contemporâneas na árdua tarefa de (re)descobrir, resgatar e preservar memórias, quaisquer que sejam. ${ }^{3}$

A familiaridade com o tema da preservação patrimonial nos dias atuais, em virtude de sua superexposição midiática, tem tornado natural ou espontâneo algo que, em realidade, é uma prática social e historicamente estabelecida, o que implica no reconhecimento de sua mutabilidade e reelaboração permanente, sendo, portanto, absolutamente incompatível com a idéia de alguma coisa natural ou dada, acabada. ${ }^{4}$ Logo, nenhuma assertiva com relação ao tema pode pretender possuir caráter definitivo ou ser portadora de verdades absolutas. Ainda assim, ou justamente por ser assim, a problematização dos discursos e das práticas relacionados com a área da preservação é tarefa sempre necessária.

No Brasil diversos trabalhos trazem uma abordagem que já se consagrou na discussão sobre as ações pioneiras de preservação do patrimônio brasileiro, as quais privilegiam os aspectos relacionados à seleção e tombamento dos bens histórico-culturais empreendida geralmente por agentes e instituições públicas, seja na esfera federal, seja nos estados e municípios. ${ }^{5}$ Outros trabalhos levantam a temática do patrimônio ambiental urbano envolvida pelo viés mais amplo da atual articulação entre políticas urbanas e políticas culturais. ${ }^{6}$ Também as questões normativas e de legislação na salvaguarda do

\footnotetext{
2 POULOT, Dominique. Uma história do patrimônio no Ocidente, séculos XVIII-XXI. Do monumento aos valores. São Paulo: Estação Liberdade, 2009, pp. 10.

3 O historiador Jacques Le Goff, em seu verbete "Passado-presente", afirma que: " $A$ aceleração da história [...] levou as massas dos países industrializados a ligarem-se nostalgicamente às suas raízes: daí a moda 'retro', o gosto pela história e pela arqueologia, o interesse pelo folclore, o entusiasmo pela fotografia, criadora de memórias e recordações, o prestígio da noção de patrimônio" (LE GOFF, Jacques. "PassadoPresente", In: História e Memória. Campinas/SP: Ed. Unicamp, 1996, pp. 220).

4 POULOT, Dominique. Op. cit., pp. 15.

5 Apenas para citar alguns: FONSECA, Maria Cecília Londres. O Patrimônio em Processo. Rio de Janeiro: UFRJ / IPHAN, 1997; RODRIGUES, Marly. Imagens do Passado. A instituição do patrimônio em São Paulo, 1969-1987. São Paulo: Ed. Unesp / Imprensa Oficial / Condephaat / Fapesp, 2000; RUBINO, Silvana. As fachadas da história: os antecedentes, a criação e os trabalhos do Serviço do Patrimônio Histórico e Artístico Nacional, 1937-1968. Campinas/SP, IFCH/UNICAMP, Dissertação de Mestrado, 1991; SANTOS, Mariza Veloso Motta. O tecido do tempo: a idéia de patrimônio cultural no Brasil, 1920-1970. Brasília, UnB, Tese de Doutorado, 1992.

${ }^{6}$ Como por exemplo: ANDRADE, Manuella Marianna. A sociedade civil na gestão urbana do bairro do Recife. São Paulo, Faculdade de Arquitetura e Urbanismo, Universidade
} 
patrimônio estão contempladas em alguns estudos, bem como suas limitações e desdobramentos. $^{7}$

O conjunto desses estudos revela que a problemática da proteção do acervo cultural brasileiro está na ordem do dia em muitos campos disciplinares e se consolidou efetivamente como questão. Todavia, a despeito da efetiva preocupação com a preservação do patrimônio brasileiro, quer seja entre um público amplo, quer se refira aos meios especializados, pouca atenção tem sido dispensada aos métodos de intervenção aplicados sobre esses bens escolhidos como memória a ser preservada. Percebe-se um grande descompasso entre as recorrentes discussões a respeito da necessidade de se preservar a memória em suas diferentes formas e manifestações frente à quase inexistência de debates sobre os meios operacionais que deveriam ser utilizados para o cumprimento de tal tarefa. $E$ quando se fala aqui em debater os meios operacionais para a preservação, não se está pensando exclusivamente nas questões técnicas, na escolha de materiais ou de procedimentos, mas, sobretudo, nos princípios teóricos que embasam (ou deveriam embasar) a escolha deste ou daquele procedimento, desta ou daquela técnica aplicada sobre um determinado bem cultural.

Poucos são os trabalhos cujo enfoque seja a restauração do patrimônio, ${ }^{8}$ aqui entendida como ação cultural que reafirma valores e

Presbiteriana Mackenzie, Dissertação de Mestrado, 2003; CASTRIOTA, Leonardo Barci. Patrimônio cultural: conceitos, políticas, instrumentos. São Paulo: Annablume, Belo Horizonte: IEDS, 2009; FERNANDES, Ana; JACQUES, Paola Berenstein (orgs.). Cadernos PPG-AU/FAUFBA - Territórios urbanos e políticas culturais. Salvador: PPGAU/FAUFBA, número especial, ano 2, 2004; KARA-JOSÉ, Beatriz. Políticas culturais e negócios urbanos. A instrumentalização da cultura na revitalização do centro de São Paulo (1975-2000). São Paulo: Annablume / Fapesp, 2007; SANT'ANNA, Márcia. A cidade-atração. A Norma de preservação de centros urbanos no Brasil dos anos 90. Salvador, FAU-UFBa, Tese de Doutorado, 2004.

${ }^{7}$ Cabe aqui destaque ao estudo sobre 0 instituto jurídico do tombamento: CASTRO, Sonia Rabello de. $O$ Estado na preservação de bens culturais: o tombamento. Rio de Janeiro: Renovar, 1991. Mas alguns trabalhos sobre o tombamento de bairros ou de áreas urbanas igualmente tratam das questões da norma e dos instrumentos de preservação, apresentando suas possibilidades e limites. Por exemplo: CUNHA FILHO, Francisco Humberto. "Impactos da Constituição Federal de 1988 sobre o tombamento de bens do patrimônio cultural brasileiro", In: Anais do IV ENECULT - Encontro de Estudos Multidisciplinares em Cultura. Salvador, UFBa, 2008. Disponível em: http://www.cult.ufba.br/enecult2008/14209-02.pdf. Acesso em: 02 fev. 2010, 10:51. FENERICH, Antônia Regina Luz. Preservação em São Paulo: análise de procedimentos metodológicos. São Paulo, FAUUSP, Dissertação de Mestrado, 2000; PIRES, Maria Coeli Simões. Da proteção ao patrimônio cultural: o tombamento como principal instituto. Belo Horizonte: Del Rey, 1994; PRATA, Juliana Mendes. Patrimônio cultural e cidade: práticas de preservação em São Paulo. São Paulo, FAUUSP, Tese de Doutorado, 2009. 
estabelece formas de ver o bem cultural, na medida em que o produto final da intervenção será quase sempre a imagem cristalizada nas memórias da comunidade que deve se (re)apropriar do bem restaurado.

A preocupação central desta Tese, assim sendo, é justamente a de desnaturalizar as práticas de restauro, na medida em que estas são, sempre, resultante de escolhas e decisões, das quais uma parcela certamente é de cunho técnico, mas não exclusivamente. São também fruto de posicionamentos frente ao que se deseja preservar e sobre qual memória se deseja perpetuar. Desse modo, o recorte adotado para o desenvolvimento do trabalho, no âmbito mais amplo da questão da preservação do patrimônio cultural, refere-se às teorias da restauração e seu desdobramento prático na ação preservacionista. Tem como objetivo discutir as questões teóricas que deveriam guiar as ações práticas de intervenção que visam à preservação de edifícios e sítios urbanos aos quais foi atribuído valor cultural, restabelecendo nexos obliterados pela naturalização das práticas de preservação acima descrita. Não se trata de discutir as formulações teóricas com finalidade em si mesmas, mas de refletir sobre a necessidade de um efetivo intercâmbio entre teoria e prática para que a preservação seja um fato concreto, tanto no que se refere a edificações isoladas quanto a conjuntos urbanos. Acredita-se que as formulações teóricas da restauração oferecem princípios de ação válidos, cuja aplicação é condição sine qua non para que as intervenções em bens culturais sejam fundamentadas e de fato preservem os aspectos formais, históricos, memoriais e simbólicos de que esses bens são portadores.

No Brasil, após uma releitura crítica das intervenções feitas durante a chamada fase heróica do SPHAN, novos parâmetros são propostos no âmbito das práticas de preservação, principalmente no tocante ao que se entende por patrimônio, aos critérios de seleção para os tombamentos e à descentralização da tutela dos bens culturais; a memória e suas diferentes formas de manifestação e seus múltiplos suportes também são incorporados ao discurso preservacionista local. A par dessas novas discussões, verificam-se referências

\footnotetext{
${ }^{8}$ Ao trabalho pioneiro de Antonio Luiz Dias de Andrade (ANDRADE, Antonio Luiz Dias de. Um Estado completo que pode jamais ter existido. São Paulo, FAU-USP, Tese de Doutorado, 1993) vem agora somar-se outros: GONÇALVES, Cristiane Souza. Restauração Arquitetônica. A experiência do SPHAN em São Paulo, 1937-1975. São Paulo: Annablume / Fapesp, 2007; MAYUMI, Lia. Taipa, canela preta e concreto. Um estudo sobre a restauração de casas bandeiristas em São Paulo. São Paulo, FAU-USP, Tese de Doutorado, 2005.
} 
recorrentes a textos teóricos da restauração - tais como a Carta de Veneza ou a Teoria da Restauração de Cesare Brandi -, as quais, entretanto, denotam um conhecimento superficial, quando não equivocado, dos princípios estabelecidos naqueles escritos, permanecendo como regra nas intervenções o empirismo ou a negligência. A noção equivocada ou a total ignorância do que venha a ser restauro, quase sempre entendido como ação que visa o retorno ao estado originário da obra ou como simples consolidação acrítica de uma determinada condição desta, certamente está na raiz da baixa qualidade das intervenções que são empreendidas sobre bens patrimoniais na atualidade $e$, conseqüentemente, na sistemática perda de valores que lhes eram inerentes e em razão dos quais esses monumentos foram conservados. Diante de tal quadro, a hipótese proposta para construção desta Tese é a da aplicabilidade das formulações teóricas da restauração à realidade brasileira atual, demonstrando os severos prejuízos a uma verdadeira ação preservacionista acarretados pela cisão entre teoria e prática no âmbito da restauração.

A presente pesquisa estrutura-se em quatro capítulos, divididos em duas partes, sendo a primeira de caráter mais conceitual e a seguinte a que aborda as questões específicas da Tese, isto é, os diálogos entre teoria e prática no campo da restauração no Brasil através da atuação do IPHAN.

A escolha do IPHAN como fonte dos exemplos adotados para análise das relações teoria-prática no campo do restauro se justifica pela representatividade do órgão federal de preservação no que tange aos parâmetros de ação para as restaurações em território nacional, seja porque desde sua fundação até a década de 1970 o IPHAN foi praticamente a única instância a empreender a tarefa da preservação no país, seja porque, mesmo após a proliferação de órgãos estaduais e municipais de proteção ao patrimônio, ainda sim a instância federal permaneceu como paradigma, chegando aos anos 1990, através do Programa Monumenta, como grande empreendedor de restaurações, em parceria com estados, municípios e a iniciativa privada. Os exemplos apresentados ao longo do trabalho foram colhidos de publicações e produções acadêmicas nacionais, julgando-se desnecessária, frente ao escopo adotado para o trabalho, uma pesquisa de fontes primárias mais aprofundada. Os exemplos encontrados nas referidas produções eram suficientemente ilustrativos das formas de aplicação (ou não) dos preceitos teóricos na prática 
preservacionista brasileira e se demonstraram eficazes para a problematização das intervenções frente aos postulados teóricos.

Tributário da noção de patrimônio, o conceito de restauração é igualmente complexo e seus contornos também estão longe de serem definitivos. Porém, desde que se constituiu como campo de conhecimento, há pelo menos dois séculos, ${ }^{9}$ o restauro pode ser delimitado como campo cultural e é dentro desses limites que o tema será aqui abordado. Especialmente ao longo da primeira parte da Tese procurar-se-á demonstrar que, ainda que se possa falar em tantos e diversos meios para se empreender uma restauração, somente se pode afirmar que as intervenções sobre bens culturais sejam verdadeiramente restauro quando sua finalidade última seja a conservação e transmissão ao futuro de tais bens, pois "per ogni monumento danneggiato o perduto, a causa d'interventi impropri, non c'è rimedio; [...] l'originalità di ciò che s'è perso rimarrà per sempre irrecuperabile" ${ }^{10}$ dado que sejam únicos e irrepetíveis. 0 primeiro capítulo apresenta, pois, uma definição capaz de enquadrar ou circunscrever 0 universo empírico de trabalho, esclarecendo o que se entende por restauração no âmbito específico desta Tese e, por conseguinte, quais intervenções em bens de interesse histórico-cultural estão excluídas de tal nomeação por extrapolarem aquele campo que se pretende isolar.

A segunda parte da Tese tem como finalidade examinar as práticas de intervenção do órgão federal de preservação do Brasil, confrontando-as com os princípios teóricos estabelecidos para a restauração em cada momento histórico. O recorte temporal adotado facilita o estabelecimento de uma análise comparada entre as teorias que regiam o campo da restauração em cada momento histórico, frente àquelas adotadas no Brasil, percebidas tanto através dos discursos como das ações implementadas. Assim, o segundo capítulo analisa as ações de preservação e, especialmente de restauração implementadas durante a chamada fase heróica do SPHAN (1937-1968), o terceiro capítulo refere-se à chamada fase moderna, que vai de 1969 até 1990, e o quarto e último capítulo trata das ações do Patrimônio Nacional dos anos 1990 até os dias atuais. Essas análises são pontuadas pelos princípios teóricos do restauro vigentes em cada

\footnotetext{
${ }^{9}$ A respeito da consolidação da restauração como campo disciplinar autônomo, ver: SETTE, Maria Piera. "Profilo storico", In: CARBONARA, Giovanni (diretto da). Trattato di Restauro Architettonico. Torino: UTET, 1996, vol. 1, pp. 111-112.

10 CARBONARA, Giovanni. "Teoria e metodi del restauro", In: Trattato di restauro architettonico (diretto da G. Carbonara), Torino: UTET, vol. 1, 1996, pp. 10-11.
} 
período, desse modo, espera-se evitar incorrer em anacronismos, imputando entendimentos atuais do campo disciplinar do restauro aos primeiros momentos de ação institucional.

Desse esforço, espera-se reafirmar a possibilidade de uma atuação prática teoricamente embasada quando se trate de intervir sobre bens de indiscutível valor histórico-cultural, de modo a contribuir para uma verdadeira preservação.

Um último esclarecimento: a apresentação das diversas abordagens da contemporânea teoria da restauração, quase sempre oriundas do ambiente europeu, como parâmetro para a ação no Brasil não representa uma atitude colonizada e nem uma apologia à adoção sem critérios ou questionamentos de conceitos e práticas estrangeiras, por serem melhores do que os nacionais. Em realidade, o que se pretende deixar claro ao longo deste trabalho é que, assim como nossas idéias de preservação são fruto de uma relação dialética entre ideais centro-europeus e os nossos próprios valores, a noção de restauro deve também ser fruto de uma reflexão construída a partir de conhecimentos e práticas sistematizados em estudos, inventários e intervenções amplamente discutidos e reelaborados ao longo dos séculos e de nossa realidade local, com suas peculiaridades e exigências. De qualquer modo, trata-se de matéria delicada (no duplo sentido: por ser a restauração atividade complexa e por recair sobre objetos "delicados", posto que com grande lastro histórico) e, diante disso, toda prudência e cautela são sempre salutares 


\title{
-CAPÍTULO 1-DEFINIÇÕES NECESSÁRIAS
}

\begin{abstract}
La nozione di restauro, che a prima vista può sembrare del tutto ovvia, è invece estremamente sfumata, equivoca, ambigua, polisensa, suscettibile di essere specificata nei modi più diversi e mai, forse, in modo definitivamente omogeneo e coerente (a meno naturalmente di una definizione del tutto arbitraria, sempre possibile e legitima, ma incapace per ciò stesso di rendere conto dell'effettiva latitudine semantica di questo singolare pseudo-termine).

Emilo Guarroni ["Premessa", In: II problema del restauro, 1971]
\end{abstract}

\section{1 - restauração: busca de uma conceituação possível}

Estabelecer de modo cabal o conceito de restauração não é tarefa fácil e talvez não seja nem mesmo possível, sobretudo porque se trata de um campo disciplinar relativamente recente e em constante reavaliação e mudança. Dada a complexidade desta disciplina em suas diversas e multiformes possibilidades de abordagem, será apresentada na primeira parte deste trabalho uma tentativa de definição do conceito de restauro, ainda que aproximada e não-definitiva, posto ser considerada absolutamente necessária para 0 seu bom desenvolvimento. Procurar-se-á, portanto, estabelecer nas linhas que se seguem uma definição capaz de enquadrar ou circunscrever o universo empírico de trabalho, esclarecendo 0 que se entende por restauração no âmbito específico desta tese e, por conseguinte, quais intervenções em bens de interesse histórico-cultural estão excluídas de tal nomeação por extrapolarem aquele campo que se pretende delimitar.

O caminho mais "natural" para dar início à conceituação de restauração seria estabelecer uma aproximação com o processo de formação histórica da disciplina, lócus a partir do qual podem constituir-se alguns primeiros critérios de análise e entendimento do fenômeno. No entanto, não se pretende apresentar aqui uma releitura extensiva da história da restauração, ${ }^{1}$ mas propor, através de

1 Para uma história do restauro, ver principalmente: CARBONARA, Giovanni. Avvicinamento al restauro. Teoria, storia, monumenti. Napoli: Liguori Editore, 1997. A partir dessa leitura, desdobra-se extensa bibliografia sobre o tema. Também se remete à leitura de: CASIELLO, Stella (a cura di). Verso una storia del restauro. Dall'età classica al primo Ottocento. Firenze: Alinea, 2008; SETTE, Maria Piera. Op. cit., pp. 111-291; JOKILEHTO, Jukka. A History of Architectural Conservation. The contribution of English, French, German and Italian thought towards an international approach to the 
alguns momentos históricos determinantes, certos aspectos teóricos que consensualmente são considerados atuais e válidos até nosso dias.

Ainda que possam existir iniciativas de apreço, preservação ou mesmo de conservação de antiguidades e monumentos herdados de culturas e tempos passados anteriores ao século XVIII, tais manifestações não eram ainda fruto de um distanciamento histórico ou da consciência de que tais bens seriam portadores de valores artísticos ou históricos. Portanto, as intervenções realizadas até esse momento, mesmo aqueles exemplos pouco numerosos que se voltam para questões de cunho estético-histórico-memorial, não podem ser chamadas de restauração na acepção atual que o termo possui, pois eram atos excepcionais, esporádicos, que não faziam parte do tratamento dessas questões dentro de um âmbito de políticas públicas culturais mais abrangentes que 0 problema passa a assumir a partir da segunda metade do século XVIII.

De fato, até a Idade Média, a preservação de edificações da Antiguidade voltava-se àquelas que se encontravam ainda em uso e todas as medidas em favor de sua manutenção e perenidade, longe de se poder chamar de restauro, se dava em atendimento a questões de caráter eminentemente pragmático. Reinava grande liberdade na apropriação dessas criações, inexistindo a perspectiva histórica no contato com tal produção. ${ }^{2}$ Com a Renascença, percebe-se uma modificação no olhar em relação às construções do passado, que gradativamente passam a ser mais apreciadas por suas qualidades artísticas e históricas. ${ }^{3}$ Começa a formar-se, então, a noção de monumento histórico tal como será delineada no início do século XX por Alois Riegl ${ }^{4}$ isto é, diferentemente daqueles monumentos intencionalmente constituídos para evocar uma lembrança, a produção de um dado momento histórico passa a adquirir significação cultural, seja por seus valores históricos, simbólicos ou artísticos, tenha ela sido produzida ou não com intenção memorial. Esta nova forma de apreciação das edificações do passado é fruto da tomada de consciência de que a ruptura entre passado e presente é inexorável. Deste

conservation of cultural property. D. Phil Thesis, Institute of Advanced Architectural Studies, The University of York, 1986.

2 CHOAY, Françoise. A Alegoria do Patrimônio. São Paulo: Ed. Unesp / Estação Liberdade, 2001, pp. 35-41.

3 KÜHL, Beatriz Mugayar. "Notas sobre a evolução do conceito de restauração", In: Arquitetura do Ferro e Arquitetura Ferroviária em São Paulo. Reflexões sobre a sua preservação. São Paulo: Ateliê Editorial, 1998, pp. 180.

${ }^{4}$ RIEGL, Aloïs. Le culte moderne des monuments. Son essence et sa genèse. Paris: Seuil, 1984. 
momento em diante, paralelamente às formas anteriores de livre apropriação das edificações antigas, empreendem-se diversas ações voltadas a salvaguardar os monumentos históricos, ainda que, na prática, a efetiva preservação dessas edificações não chegasse a bom termo. Nesse sentido, por mais discutidas que sejam as origens da restauração, parece haver consenso entre os vários estudiosos do tema no fato de que esta se estrutura mais consistentemente a partir de finais do século XVIII e se consolida como campo disciplinar autônomo no final do século XIX e início do século XX. ${ }^{5}$

Dentro desse horizonte histórico, portanto, a primeira definição do moderno conceito de restauração que se pode encontrar é aquela dada por Viollet-le-Duc no verbete Restauration do seu Dictionnaire Raisonné de I'Architecture Française du Xle au XVle Siécle, no qual afirma que "Restaurar um edifício não é mantê-lo, repará-lo ou refazê-lo, é restabelecê-lo em um estado completo que pode não ter existido nunca em um dado momento". 6

Excetuando-se a definição-negação emitida por John Ruskin ainda no século $\mathrm{XIX},{ }^{7}$ a disciplina somente verá uma outra definição acabada do conceito de restauração em meados do século XX com Cesare Brandi, o qual afirma que a restauração consiste no "momento metodológico do reconhecimento da obra

\footnotetext{
${ }^{5}$ Maria Piera Sette afirma que: "In generale, fino agli inizi del XIX secolo è improprio parlare di restauro, quale s'intende oggi [...] Fino a tutto il settecento l'operatività sulle preesistenze è sopratutto guidata dalla certeza dei protagonisti - pubblico, committenti, artefici - di operare in una condizione di sostanziale continuità con i tempi trascorsi; vale a dire senza distinguere il presente del passato". Ver: SETTE, Maria Piera. Op. cit., pp. 111-112. B. Paolo Torsello afirma que: "C'è un punto almeno sul quale i padri storici del "restauro" sembrano concordi. Malgrado la differenza, e spesso l'opposizione, dei rispettivi punti di vista, essi sono unanimi nel fissare le origine del moderno restauro archittetonico nel secolo XIX". Ver: TORSELLO, B. Paolo. Restauro architettonico. Padri, teorie, immagini. Milano: Franco Angeli, $7^{a}$ edizione, 2001, pp. 17. A esse respeito ver também: LA REGINA, Francesco. "Architettura e 'coscienza del passato'. Appunti per uma ricerca sulle origini e sul significato del restauro moderno: l'antichità classica", In: CASIELLO, Stella (a cura di). Restauro dalla teoria alla prassi. Napoli: Electa Napoli, 2000, pp. 28-30.

6 VIOLLET-LE-DUC, Eugène Emmanuel. Dictionnaire Raisonné de l'Architecture Française du XI au XVI Siècle. Paris: A. Morel, 1866-1868, 10 vol. Aqui será adotada a tradução do verbete "Restauração" feita por Beatriz Mugayar Kühl: VIOLLET-LE-DUC, Eugène Emmanuel. Restauração. Cotia-SP: Ateliê Editorial, 2000, pp. 29.

7 No aforisma 31 de "A lâmpada da memória" Ruskin afirma que a restauração "significa a mais total destruição que um edifício pode sofrer: uma destruição da qual não se salva nenhum vestígio: uma destruição acompanhada pela falsa descrição da coisa destruída". Ver: RUSKIN, John. A lâmpada da memória. Tradução e apresentação de Maria Lucia Bressan Pinheiro. Cotia-SP: Ateliê Editorial, 2008, pp. 79.
} 
de arte, na sua consistência física e na sua dúplice polaridade estética e histórica, com vistas à sua transmissão para o futuro".8

Praticamente cem anos separam a primeira da segunda definição do conceito de restauro e nesse ínterim profundas modificações se verificam no campo prático e igualmente na metodologia de intervenção em arquiteturas do passado. Tais modificações continuam a se processar, porém, não se assistiu a nenhuma nova definição, antes, o que se percebe é uma tendência à reelaboração, que se dá a partir das definições pré-existentes. ${ }^{9}$

Diferentes estudiosos definem a restauração em modos igualmente diversos, em função de seus respectivos endereçamentos teóricos, dando enfoque maior aos critérios conservativos ou naqueles inovativos ou ainda enfatizando a necessidade de balancear a conservação e a inovação; alguns restauradores têm uma aproximação mais voltada para a manutenção/conservação dos aspectos materiais da obra, outros, ao contrário, mais focada em projetar na e para a pré-existência. Equacionar os aspectos históricos (monumento como documento de história) com aqueles de natureza estética (monumento enquanto imagem figurada e expressão formal) é para muitos o grande desafio em um trabalho de restauração. Outros restauradores, ao contrário, defendem a prevalência dos aspectos documentais, contrapostos àqueles que vêem no restauro apenas uma questão de restituição da forma. Há ainda os que advogam ser o restauro uma atividade exclusivamente técnicocientífica, a ser resolvida dentro de um quadro de especialistas da arquitetura, da engenharia, da arqueologia, da química, da biologia, etc.

Apenas para ilustrar as colocações acima feitas, apresentam-se a seguir algumas conceituações de restauro elaboradas ao longo do século XX e até os dias de hoje por diferentes pensadores de várias matrizes de pensamento.

\footnotetext{
${ }^{8}$ BRANDI, Cesare. Teoria da Restauração. Cotia-SP: Ateliê Editorial, 2004, pp. 30.

9 Diversas definições, dadas por representantes de diferentes endereçamentos teóricos do restauro, podem ser apreciadas no livro: TORSELLO, B. Paolo et alli. Che cos'è il restauro? Venezia: Marsilio, 2005. Também se remete aos seguintes textos: BONSANTI, Giorgio. "Per una definizione di restauro", In: Kermes: la rivista del restauro, vol. 19, n. 62, aprile/giugno 2006, pp. 67-71; DEZZI BARDESCHI, Marco. "II restauro: una nuova definizione per un'antica (ambigua) disciplina", In: Ananke: cultura, storia e tecniche della conservazione, nuova serie, n. 41, 2004, pp. 2-5; LA REGINA, Francesco. "L'opera, I'attività, le istruzioni: appunti su una definizione del restauro architettonico", In: Palladio: rivista di storia dell'architettura e restauro, n. 24, 1999, pp. 81-88; SANTORO, Lucio. "II contributo italiano alla definizione concettuale e metodologia del restauro", In: Restauro. Quaderni di restauro dei monumenti e di urbanistica dei centri antichi, n. 43, 1979, pp. 576.
} 
Para o historiador da arte Giulio Carlo Argan, o restauro:

[...] è oggi concordemente considerato come attività rigorosamente scientifica e precisamente come indagine filologica diretta a ritrovare $e$ rimettere in evidenza il testo originale dell'opera, eliminando alterazioni e sovrapposizioni di ogni genere fino a consentire di quel testo una lettura chiara e storicamente esatta. 10

O austríaco Max Dvořák afirma que:

[...] a restauração não deve jamais ser um fim em si mesma, mas deve significar um meio de assegurar aos monumentos sua integridade e seu efeito, conservando-os piedosamente para as futuras gerações. ${ }^{11}$

Para o belga Paul Philippot, o qual esteve por muitos anos à frente do International Centre for the Study of the Preservation and Restoration of Cultural Property (ICCROM) - UNESCO, o restauro:

reste essentiellement une hypothèse critique, une proposition toujours modifiable, sans altération de l'original, lorsqu'une critique mieux éclairée le jugera nécessaire. [...] l'interprétation critique ne peut évidemment se limiter à un jugement verbal; il faut qu'elle se concrétise en acte [...] qu'elle se réalise sur le plan imaginaire où est revécue intuitivement la forme. C'est par que la restauration est essentiellement un travail d'art et requiert une culture pratique de l'imagination visuelle. ${ }^{12}$

A arquiteta Liliana Grassi, em seu verbete Restauração, assim define restauro arquitetônico:

[...] una complessa operazione critica che, proprio in quanto tale, trae il suo dato fondante dalla concezione della cultura, cioè della storia dell'arte, e, nel caso specifico, dell'architettura. Le motivazioni dei diversi interventi sono pertanto in continua discussione, si che non è possibile racchiudere in una definizione risolutiva ed univoca il principio primo del restauro, giacchè esso postula una scelta preliminare sulla legittimità di conservare la materia dell'opera, in quanto veicolo della forma, cioè in quanto immagine, oppure in quanto documento. [...] Scopo indiscusso resta, in ogni caso, quello di assicurare la sussistenza di un'opera nel presente e la sua trasmissione nel futuro [...].13

Giovanni Carbonara, por sua vez, coloca:

S'intende per restauro qualsiasi intervento volto a tutelare ed a trasmettere integralmente al futuro, facilitandone la lettura e senza cancellarne le tracce del passaggio nel tempo, le opere d'interesse storico-artistico ed ambientale; esso si fonda sul rispetto della sostanza antica e delle documentazioni autentiche costituite da tali opere,

${ }^{10}$ Apud CARBONARA, Giovanni. Avvicinamento..., op. cit., pp. 28.

11 DVOŘÁK, Max. Catecismo da preservação de monumentos. Cotia-SP: Aletilê, 2008, pp. 99.

12 PHILIPPOT, Paul. "Le problème de l'intégration des lacunes dans la restauration des peintures", In: Bulletin de l'Institut Royal du Patrimoine Artistique, n. II, 1959, pp. 5-6.

${ }^{13}$ GRASSI, Liliana. "Restauro", In: II restauro e il recupero creativo della memoria storica. A cura di Maria Antonieta Crippa e Emanuela Sorbo. Roma: Bonsignori, 2007, pp. 119. 
proponendosi, inoltre, come atto d'interpretazione critica non verbale ma espressa nel concreto operare. Più precisamente come ipotese critica e proposizione sempre modificabile, senza che per essa si alteri irreversibilmente l'originale. ${ }^{14}$

Para B. Paolo Torsello,

Riconoscere l'opera in quanto testo, difendendone l'intrinseca valenza ermeneutica, delinea il compito della conservazione, il cui fine più ambizioso è di tutelare una possibilità del comprendere [...]. ${ }^{15}$

$\mathrm{Na}$ Carta della conservazione e del restauro degli oggetti d'arte e di cultura, de 1987, cuja elaboração foi coordenada por Paolo Marconi assim se define o termo restauração:

Restauro: qualsiasi intervento che, nel rispetto dei principi della conservazione e sulla base di previe indagini conoscitive di ogni tipo, sia rivolto a restituire all'oggetto, nei limiti del possibile, la relativa leggibilità e, ove occorra, l'uso. ${ }^{16}$

O arquiteto Marco Dezzi Bardeschi por seu turno, afirma que:

Restaurare una fabbrica significa innanzitutto contenerne il decadimento strutturale, la fatiscenza e il degrado biologico, saperla conservare, non semplicemente in effige ma nelle sue reali strutture fisiche, nei componenti materici che ne costituiscono l'irrepetibile contesto specifico, unico, individuo in cui solo consiste l'autenticità stessa dell'opera. ${ }^{17}$

Ignacio Paricio adverte que:

El trabajo sobre edificos históricos es un proyecto con más datos previos. Plantea todas las dificultades de la proyectación arquitectónica con un grado mayor de complejidad. ${ }^{18}$

De fato, como afirma Francesco Doglione e como se pode apreender a partir da diversidade de conceituações e definições acima apresentadas, a restauração "non ha una definizione, ma ne ha molte anche profondamente diverse tra loro, come in un caleidoscopio in cui ogni immagine, fissa per un istante, varia al più piccolo spostamento".19 Ainda que tais conceituações guardem grandes diferenças entre si, são todas válidas e pertinentes dentro do

${ }^{14}$ CARBONARA, Giovanni. Avvicinamento..., op. cit., pp. 33.

15 TORSELLO, B. Paolo. "La dialettica restauro/progetto", In: Ananke. Cultura, storia e tecniche della conservazione. Firenze: Alinea, n. 19, settembre 1997, pp. 31.

16 "Carta 1987 della conservazione e del restauro degli oggetti d'arte e di cultura", In: MARCONI, Paolo. II restauro e l'architetto. Teoria e pratica in due secoli di dibattito. Venezia: Marsilio, $3^{\mathrm{a}}$ ed., 2002, pp. 208.

17 DEZZI BARDESCHI, Marco. Restauro: punto e da capo. Frammenti per una (impossibile) teoria. Milano: Franco Angeli, $7^{\text {a }}$ ed., 2005, pp. 53. Grifo do autor.

18 PARICIO, Ignacio. "No lo conocerás bastante. La exigente intervención en el legado construido", In: Arquitectura Viva, n. 110, 2006, pp. 32.

${ }^{19}$ DOGLIONE, Francesco. Nel restauro. Progetti per le architetture del passato. Venezia: Marsilio / IUAV, 2008, pp. 15. 
horizonte disciplinar da restauração, comprovando o caráter caleidoscópico de que o restauro está imbuído.

Porém, apesar deste modo multiforme, em grande parte descendente do endereçamento teórico de quem a define, a restauração não pode ser discutida fora do campo cultural - seu único foro legítimo -, sob risco de tornarse manipulação ou destruição injustificável daqueles objetos que se deseja preservar. Se até o século XV era aceitável que a apropriação de edificações do passado tivesse um escopo eminentemente ou quase exclusivamente utilitário, a partir do amadurecimento da noção de monumento histórico tal situação lentamente se transforma. A consciência de que as arquiteturas recebidas como herança das gerações e civilizações do passado pertencem a um momento histórico outro, diferente do atual presente histórico, tornou a apropriação de tais bens um ato de cultura, e é somente dentro da esfera cultural que se pode pensar e discutir as proposições de restauro.

Diante da variedade de possiveis definições para a restauração, podese começar a circunscrever seus limites a partir do que ela não seja, isto é, excluindo diversas formas de intervenção em bens de reconhecido valor histórico-cultural que, a despeito de incluírem ações conservativas, se pautam por objetivos e métodos estranhos ao campo disciplinar e, portanto, não podem ser enquadradas como restauro.

De antemão deve-se estabelecer que só é possível falar em restauro nos casos em que previamente houver o reconhecimento do valor cultural de um determinado bem. De fato, somente a partir do momento em que se atribui a uma arquitetura, a uma área urbana, uma paisagem ou a outro qualquer produto da ação humana um determinado valor (que pode ser de diversas naturezas: histórico, estético ou artístico, memorial, simbólico, antropológico, etc) é que se passa da noção de reparação ou restabelecimento da funcionalidade para 0 verdadeiro conceito de restauro, tal como exposto por Cesare Brandi:

O produto humano a que se volta esse reconhecimento se encontra ali, diante de nossos olhos, mas pode ser classificado de modo genérico entre os produtos da atividade humana, até que o reconhecimento que a consciência faz dele como obra de arte, excetue-o, definitivamente, do comum dos outros produtos. [...] qualquer comportamento em relação à obra de arte, nisso compreendendo a intervenção de restauro, depende 
de que ocorra o reconhecimento ou não da obra de arte como obra de arte. $^{20}$

E o mesmo Brandi conclui:

Dessa estrutura fundamental da obra de arte, na recepção que dela faz a consciência individual, deverão naturalmente derivar também os princípios em que será necessário que a restauração se inspire na sua atuação prática. ${ }^{21}$

Umberto Baldini, em sua obra Teoria del restauro e unità di metodologia, estabelece como ponto de partida para a conservação ou restauração de um bem cultural primeiramente uma acurada análise filológica, na qual se procede à identificação do objeto em sua realidade tal como chegou aos nossos dias. Esta etapa analítica, segundo o autor, é fundamental por se tratar de uma operação que garante o conhecimento e a consciência do objeto em sua realidade material e formal e, portanto, " $E$ da qui che si deve partire l'intervento conservativo", ${ }^{22}$ dado que:

Non si può essere conservatori se non si conoscono, e fino in fondo per quel che sono e che valgono, gli oggetti da conservare; non si può operare su di essi affidandosi solo al gusto da esteti sia pure raffinati o alla solo materiale abilità tecnica sia pure ad alto livello. ${ }^{23}$

Obviamente a noção de monumento alargou-se paulatinamente nos últimos anos, não se tratando mais de uma idéia erudita na qual apenas alguns exemplares de excepcional fatura são contemplados. Desde a década de 1960, percebe-se um extenso movimento no sentido de ampliar aquilo que se entende por patrimônio, que passa a incorporar bens de tipologias mais diversas e de períodos mais recentes. Entretanto, tal ampliação conceitual não anula a validade das afirmações brandianas acima colocadas, sendo suficiente e ainda assim consistente a substituição do termo "obra de arte" pelo de "bem cultural", pois independentemente do conceito filosófico a embasar a noção de arte em cada tempo ou cultura, Brandi

Unicamente afferma la possibile individuazione, nell'ambito dei prodotti dell'atività umana, di particolari manufatti, che si eccettuino dalla soddisfazione immediata di bisogni pratici o che si riducano nei termini dell'utensilità. II riconoscimento da parte della coscienza umana della determinata qualità che è inerente all'oggetto-opera d'arte, indipendentemente dal modo come si è pervenuti a tale riconoscimento, dalle implicazioni più prettamente idealistiche alle induzioni di stampo più

20 BRANDI, Cesare. Op. cit., pp. 27-28.

${ }^{21}$ Idem, pp. 30.

22 BALDINI, Umberto. Teoria del restauro e unità di metodologia, vol. I. Firenze: Nardini, 10ª ed., 2003, pp. 11.

${ }^{23}$ Idem, pp. 5. 
coerentemente pragmatista, è il presupposto e il fondamento della teoria del restauro. ${ }^{24}$

Qualquer que seja o valor atribuído a uma manufatura, a partir deste ato de reconhecimento de valor esta passa a se excetuar do restante dos comuns produtos do fazer humano e, por conseqüência, passa a exigir uma ação restaurativa e não outro tipo qualquer de intervenção. ${ }^{25}$

No entanto, mesmo nos casos em que há consenso sobre o valor de um determinado bem cultural, diversas formas de intervenção de variadas naturezas são levadas a cabo quase sempre a despeito de tal reconhecimento. Nota-se que paralelamente à verificada expansão das práticas patrimoniais nesses últimos decênios, novas formas de atuação e gestão dos bens culturais ascendem, sendo praticadas de forma totalmente isolada das reflexões teóricas desenvolvidas dentro do campo disciplinar da restauração, correndo à margem ou mesmo na total ignorância deste. De um caminhar em paralelo, passa-se a uma relação estanque entre aqueles que se dedicam ao estudo e às reflexões teóricas sobre a restauração e aqueles que estão no campo da atuação prática sobre os monumentos. Progressivamente se assiste à invasão do território dos bens de interesse histórico-cultural pela cultura de massas e a restauração antes especialidade de poucos - passa a ser alvo de múltiplos agentes, que se arrogam o direito de agir em favor da preservação da memória coletiva, ainda que sejam por vezes totalmente despreparados para tal tarefa.

Tais intervenções, na quase totalidade dos casos, procuram esquivar-se do termo restauração, ainda que se coloquem como ações de preservação da memória e de seus suportes materiais. Uma vasta nomenclatura se desenvolveu nos últimos anos com o objetivo de classificar as práticas levadas a termo em arquiteturas e áreas de interesse histórico-cultural, tais como revitalização, renovação, reciclagem, retrofit, dentre outras. Nesses casos, geralmente

24 CORDARO, Michele. "Restauro e tutela: scritti scelti (1969-1999)", In: Annali dell'Associazione Ranuccio Bianchi Bandinelli, n. 8, 2000, pp. 63.

25 Brandi coloca que "apesar de 0 reconhecimento dar-se sempre na consciência singular, naquele momento pertence à consciência universal, e 0 indivíduo que frui daquela revelação imediata, impõe a si próprio o imperativo categórico como 0 imperativo moral, da conservação". Ver: BRANDI, Cesare. Op. cit., pp. 31 (grifo nosso). Segundo Beatriz M. Kühl, "O 'reconhecimento' da teoria de Brandi é uma operação, com raízes na fenomenologia, profunda e complexa de deixar-se penetrar na obra de arte e no processo que a produziu, examinando-a em sua plenitude formal, buscando, por assim dizer, sua realidade ontológica". Ver: KÜHL, Beatriz Mugayar. "História e Ética na Conservação e na Restauração de Monumentos Históricos", In: Revista CPC, São Paulo, vol. 1, n. 1, nov. 2005/ abr. 2006, pp. 22-23. 
prevalece uma abordagem pragmática e uma visão imediatista, com pouca ou nenhuma pesquisa histórica e apressados estudos das características técnicoconstrutivas e das patologias do monumento em causa. Por um lado, busca-se uma adequação a qualquer custo do bem cultural às exigências de conforto e padrão de ocupação contemporâneos; de outro, visa-se apresentar 0 monumento com uma aparência rejuvenescida, que satisfaça ao que 0 senso comum entende por restauração: uma ação que teria por objetivo recuperar o "antigo esplendor" do bem cultural, isto é, trazê-lo de volta àquele presumido estado originário, esquecendo que “... restaurar, é bom lembrar, não significa recuperar, nem modernizar". 26

Mesmo algumas intervenções que se autodenominam restauração, pouco ou nada guardam de semelhança com os objetivos e os métodos pertinentes à disciplina, dado que prescindem de um verdadeiro compromisso com a preservação da matéria original que conforma o monumento, seja através de recriações e reconstruções de aspectos perdidos, seja através da adoção de materiais inadequados que danificam a estrutura original.

Diante desta heterogeneidade atualmente presente no campo do restauro, 0 arquiteto B. Paolo Torsello apresenta com muita clareza um balanço do "estranho destino" da disciplina:

La massima intensità di dibattito attorno alla disciplina coincide con una fase di generale indifferenza verso la tutela, almeno da parte del pensiero comune e di chi guida la cosa pubblica. Poi, dopo gli anni sessanta del secolo appena trascorso, la situazione si capovolge: aumentano gli investimenti e le attenzione per il patrimonio storico ma cala l'interesse per l'elaborazione teorica. ${ }^{27}$

E o mesmo autor prossegue na constatação dos resultados desta inversão que se processa:

Quegli oggetti, che una volta soffrivano per carenza di cure, oggi rischiano d'essere travolti da un eccesso di attenzione, soprattutto se l'eterogeneità degli approcci e la confusione dei linguaggi si esercita sulla loro fragile materia, rischiando di compromettere una risorsa autenticamente produttiva proprio sul piano sociale, economico, culturale. 28

De outra parte, nota-se que os debates corriqueiramente feitos em torno ao restauro se concentram nas questões de natureza técnica e operativa,

${ }^{26}$ ARGAN, Giulio Carlo. História da arte como história da cidade. São Paulo: Martins Fontes, 1993, pp. 80.

${ }^{27}$ TORSELLO, B. Paolo. "Che cos'è il restauro?", In: Che cos'è..., op. cit., pp. 10.

28 Idem, pp. 13-14. 
abdicando completamente da necessidade de primeiramente discutir quais fundamentos dão sustentação a este operar, como já acenava Torsello. Tal postura implica graves perdas em ambos os lados: perde a reflexão teórica, que não pode contar com a força da verificação operacional do canteiro como lócus privilegiado de aprendizado e confirmação das teses sustentadas na academia; perde também a esfera prática, empobrecida e esvaziada de seu real sentido cultural, transformada num acúmulo de procedimentos-padrão "cientificamente isentos" e objetivamente determinados, como defende a corrente conhecida como "restauração objetiva". ${ }^{29}$

Deve-se, no entanto, questionar a possibilidade de agir com esta propalada isenção em uma intervenção sobre um bem cultural, pois como poderiam os restauradores abstrair por completo sua formação, com todos os compromissos que tal formação implica em afinidades teóricas, doutrinárias e até mesmo ideológicas? E como imaginar que um ato de restauro é desvinculado do momento - e de todas as suas injunções em todos os campos - em que é feito? Não é factível que um profissional abstenha-se de pensar, eximindo-se de manifestar suas preferências e posicionamentos, que, por mais bem fundamentados que sejam (e devem ser), são fruto de um presente histórico, para responder somente à "razões técnicas" decorrentes de "levantamento de dados" e "análises científicas" como sugere a "restauração objetiva", posto que

No hay restauración exclusivamente técnica, neutra desde una aproximación arquitectónica. Hasta il planteamiento aparentemente más simple, el que sólo exige recomponer unas piezas, reparar unas cornisas, reponer unas tejas y repintar unos paramentos, exige la sensibilidad de un buen arquitecto. 30

O fato de negar a restauração como procedimento de natureza exclusivamente técnica e isenta não representa de forma nenhuma a defesa de

\footnotetext{
29 Propagada em ambiente catalão, a chamada "restauração objetiva", nas palavras de A. Moreno-Navarro: "tiene que ser entendida, por lo tanto, como aquella en que, a diferencia de lo que ha sido más habitual hasta ahora, cuenta más el objeto (el monumento) - las necesidades objetivas (ahora sí en el sentido de ciertas) del monumento y de su entorno humano - que la manera de pensar o de sentir del sujeto restaurador, es decir, que las teorias, doctrinas, ideologías o esculeas genéricas con las que éste se pueda identificar". Ver: MORENO-NAVARRO, Antoni González. Conservació preventiva: última etapa. Memòria SPAL 1999-2001. Barcelona: Diputació de Barcelona, Xarxa de Municipis, Àrea d'Infraestructures, Urbanisme i Habitatge, Servei de Patrimoni Arquitectònic Local, 2006, pp. 17, nota 2. E também: MORENO-NAVARRO, Antoni González. "Il restauro oggettivo", In: CRISTINELLI, Giuseppe \& FORAMITTI, Vittorio (a cura di). II restauro fra identità e autenticità. Atti della tavola rotonda "I principi fondativi del restauro architettonico". Venezia: Marsilio, 2000, pp. 97-103.

30 PARICIO, Ignacio. Op. cit., pp. 33.
} 
uma ação personalista ou voluntarista, ao contrário, defende-se aqui a adoção de uma postura consciente e ponderada, balanceada pelos diversos componentes de diferentes formações e áreas do conhecimento (necessárias a qualquer trabalho de restauro sério), dado que nenhum restaurador deva restringir-se ao papel de "idiota útil", como bem coloca Sandro Scarrocchia. ${ }^{31}$

Frente às variadas "intromissões" que hoje se presenciam no campo da restauração, faz-se necessário distinguir posturas que, embora distintas, estão circunscritas dentro deste campo e aquelas que o extrapolam de todo. As ações sobre bens de interesse cultural calcada na noção de exploração econômica do patrimônio, aquelas de cunho prático e que têm no uso sua única finalidade, ou ainda manipulações políticas de diversas naturezas, são todas ações pseudoconservativas e que resultam muitas vezes em grandes e injustificáveis alterações, desnaturando os monumentos e, por isso, exorbitando completamente os pressupostos de um verdadeiro restauro.

Excluindo esses diversos modos de intervenção sobre bens de interesse histórico-cultural do campo da restauração, restringe-se em muito 0 universo empírico de análise e avança-se no intento de circunscrever o conceito de restauração que se considera válido no âmbito deste trabalho.

O primeiro ponto a ser destacado diz respeito à finalidade da intervenção de restauro: esta é sempre uma ação do presente que tem por objetivo a conservação daquilo que nos foi legado pelo passado de modo idôneo, visando sua transmissão às gerações futuras, na medida em que se reconhece que tal legado seja portador de um valor de cultura.

Em nenhuma hipótese se trata de levar a obra ao seu estado originário ou ao seu "antigo esplendor", como habitualmente se diz. Tal visão, que identifica a restauração com a reconstituição do monumento à sua feição original (ou pretensamente originária) é uma noção que teve seu apogeu no século XIX, descartada posteriormente em face de novas proposições do campo disciplinar. A idéia de restauro como refazimento começa a ser questionada já nos últimos decênios do século XIX32 e sua efetiva reprovação se confirma nos anos 1930

31 SCARROCCHIA, Sandro. Alois Riegl: Teoria e prassi della conservazione dei monumenti. Bologna: Accademia Clementina di Bologna, 1995, pp. 61.

32 Principalmente a partir das propostas de Camillo Boito, divulgadas durante 0 Congresso Nazionale degli Ingegneri ed Architetti, ocorrido em 1883 em Roma. Vide: LA REGINA, Francesco. II restauro dell'architettura, l'architettura del restauro. Napoli: Liguori, 2005, pp. 26. 
com a Carta de Atenas, na qual afirma-se "uma tendência geral a abandonar as reconstituições integrais, evitando assim seus riscos, pela adoção de uma manutenção regular e permanente, apropriada para assegurar a conservação dos edifícios". E conclui com a seguinte recomendação: "Nos casos em que uma restauração pareça indispensável, [...] a conferência recomenda que se respeite a obra histórica e artística do passado" ${ }^{33}$ Já a partir das primeiras décadas do século XX, portanto, quando se fala em restauração trata-se de buscar consolidar e conservar o que chegou até o presente, eliminando, quanto possível, fontes de degradação de modo a garantir sua permanência pelo mais longo tempo fatível, levando em conta que "a restauração deve eliminar o desgaste, mas não a idade da obra de arte, permitir-Ihe viver durante um longo tempo, mas não rejuvenescê-la". ${ }^{34}$

Noção aprofundada e aperfeiçoada durante o II Congresso dos Arquitetos e Técnicos dos Monumentos Históricos, sintetizada na Carta de Veneza de 1964, documento do qual o Brasil é signatário e que estabelece que a restauração baseia-se no respeito pela autenticidade material da obra, visando "conservar e revelar os valores estéticos e históricos do monumento e fundamenta-se no respeito pelo material original e aos documentos autênticos". ${ }^{35}$

Muitos afirmam que a Carta de Veneza estaria ultrapassada, superada por documentos posteriores do ICOMOS, no entanto, as Cartas subseqüentes à de Veneza, tais como a de Florença (1981) ou de Washington (1987), são complementares ou abordam temas específicos, dado o caráter geral e indicativo que a de Veneza possui. Nenhuma delas, porém, tem caráter substitutivo e em diversos documentos produzidos pelo ICOMOS desde então sua validade é sempre reiterada.

Portanto, à luz do que preconizam os mais atuais conceitos no campo, entende-se que o restauro pode, no máximo, revelar a condição atual da matéria original, diminuindo 0 ritmo de degradação, visando sua manutenção e permanência para fruição das gerações futuras.

A partir desse objetivo central da restauração podem-se extrair alguns princípios elementares de ação que devem ser adotados de modo concomitante

${ }^{33}$ Carta de Atenas - Escritório Internacional dos Museus / Sociedade das Nações, In: Cartas Patrimoniais. Rio de Janeiro: IPHAN, $2^{\text {a }}$ ed., 2000, pp. 13.

${ }^{34}$ ARGAN, Giulio Carlo. Op. cit., pp. 65-66.

35 Carta de Veneza - Carta internacional sobre conservação e restauração de monumentos e sítios (1964), In: Cartas Patrimoniais, op. cit, pp. 93. 
e não excludente a serem mais detidamente apresentados a seguir: o primeiro deles é a mínima intervenção; o segundo é a distingüibilidade; e o terceiro, a reversibilidade (ou, segundo definição mais precisa que tem sido reiterada nos últimos anos, "re-trabalhabilidade").36

Ao contrário do que se pode supor, a restauração não significa um embalsamamento do bem cultural, congelando-o em uma dada situação. Ainda que conservativa, a restauração é sempre uma intervenção que comporta transformações, requerendo em alguns casos inclusive ações não-conservativas. Porém, nos casos em que tais modificações sejam necessárias, devem ser sempre controladas e, em nenhuma hipótese, podem ser gratuitas. Se é certo que qualquer restauração implica inevitáveis modificações no tecido da obra (mesmo uma simples limpeza resulta numa "nova" imagem do bem cultural), é igualmente certo que não são admissíveis transformações apenas porque assim deseja o responsável pelo projeto de restauro ou ainda para adequações a qualquer custo, visando um novo uso que se pretenda dar ao monumento.

Toda e qualquer transformação deve estar sujeita ao objetivo primeiro da restauração que é a conservação e transmissão ao futuro do bem cultural em sua realidade formal e histórica e extrair daí sua justificativa e método de ação. Nesse sentido, toda intervenção restauradora deve concentrar-se a fazer 0 mínimo necessário, evitando desnaturar o monumento seja do ponto de vista artístico, seja como documento histórico. No caso de bens arquitetônicos e em paisagens urbanas, estabelecer de modo preciso qual é esse mínimo necessário não é tarefa simples e requer, por isso mesmo, muita cautela e zelo.

Qualquer intervenção não-conservativa deve ser rigorosamente justificada e documentada e os acréscimos que se fizerem necessários devem conter a marca do presente, isto é, devem utilizar linguagem e material da contemporaneidade, evitando que se possa incorrer no erro de confundir a matéria antiga com aquela nova adição. Como já acenava Camillo Boito, é melhor um "restauro mal feito", em que se distingam os elementos originais daqueles acrescidos posteriormente, do que um "restauro bem feito", aquele que

\footnotetext{
${ }^{36}$ Princípios já estabelecidos desde 0 início do século XIX, principalmente em relação ao restauro arqueológico. A esse respeito ver: KÜHL, Beatriz Mugayar. "Notas sobre...", op. cit., pp. 183-185.
} 
demonstra tal capacidade de mimetizar os elementos originais que tornam tal distinção uma fadigosa atividade..$^{37}$

Deve-se destacar, todavia, que a distinção entre os elementos originais e aqueles acrescidos posteriormente não precisa necessariamente ser feita de maneira gritante ou contrastante, sendo suficiente que um olhar mais atento ou mais detido, aproximando-se, possa reconhecer tal diferença, de outro modo se o contraste é muito ostensivo -, corre-se o risco de transformá-lo no "centro das atenções", condenando a estrutura original a ser mera figurante, invertendo, dessa forma, a lógica da restauração.

Ainda assim, deve-se dizer aqui que o contraste ostensivo é uma das possibilidades de operar a distinguibilidade, ainda que não a única. Giovanni Carbonara, em um artigo para a Revista Palladio, ${ }^{38}$ enumera aproximadamente uma dezena de modos de aproximação entre contemporâneo e pré-existência. Dentre aquelas ações que têm na pré-existência seu foco e não o inverso (o antigo apenas como acessório na criação do novo), grosso modo, pode-se elencar as seguintes formas de inserções contemporâneas em áreas ou em bens históricos: elas podem seguir as sugestões da própria obra a ser restaurada, agindo em consonância com esta; ao contrário podem ser repristinatórias, agindo em assonância; ou ainda estabelecer um claro contraste, de modo dissonante. ${ }^{39}$ A opção a ser adotada em cada caso particular se resolve através de um projeto arquitetônico e se vale da competência e sensibilidade da equipe de projetistas.

Além de claramente distinguíveis, tais adições devem também ser feitas de modo reversível, ou seja, sem destruir a matéria original e, quando isso não seja possível, estudando-se atentamente a forma de menor impacto e menor dano ao bem. Em qualquer caso, a ação restauradora não deve alterar a obra em sua substância, colocando-se respeitosamente ante a pré-existência. Também a compatibilidade entre o novo material e a estrutura antiga deve ser

\footnotetext{
${ }^{37}$ Diz assim Boito: "[...] io preferisco i restauri mal fatti ai restauri fatti bene. Mentre quelli, in grazia della benefica ignoranza, mi lasciano chiaramente distinguere la parte antica dalla parte moderna, questi, con ammirabile scienza ed astuzia facendo parere antico il nuovo, mi mettono in una si fiera perplessità di giudizio, che il diletto di contemplare il monumento sparisce, e lo studiarlo diventa una fatica fastidiosissima". BOITO, Camillo. Questioni pratiche di Belle Arti. Milano: Hoepli, 1893, pp. 4.

38 CARBONARA, Giovanni. "Architettura e restauro oggi a confronto", In: Palladio, n. 35, 2005, pp. 99-128, especialmente pp. 118-123.

${ }^{39}$ Sobre este tema, além da referência ao artigo de Carbonara supracitado, remete-se também ao seguinte texto: KÜHL, Beatriz Mugayar. "Restauração hoje: método, projeto e criatividade", In: Desígnio - Revista de História da Arquitetura e do Urbanismo. São Paulo: FAUUSP / Annablume, n. 6, nov/2007, pp. 27-29.
} 
cuidadosamente analisada, de modo a evitar que a intervenção acarrete ulteriores danos ao monumento, posto que a restauração não deve impedir, mas facilitar qualquer intervenção futura, quando uma crítica mais esclarecida assim 0 exigir, como afirmava Paul Philippot. ${ }^{40}$ Toda e qualquer intervenção de restauro, por ser um ato alicerçado nos conhecimentos e na crítica contemporânea, tem pertinência relativa e, por isso, não pode agir de maneira leviana ou descuidada, desnaturando 0 objeto que deveria justamente preservar. Porém, 0 fato de 0 restauro ter pertinência relativa não pode jamais levar a crer que ele seja um ato desnecessário ou dispensável, dado que a negligência pode ser a causa da efetiva e perene perda do bem cultural.

Como se pode perceber não se trata de uma atuação simples, na qual a reprodução automática de fórmulas prontas possa trazer bons resultados, mas de uma atividade complexa que implica em grande responsabilidade social e que exige a conjugação de diversos saberes e competências, sendo, portanto, necessariamente trabalho para uma equipe multidisciplinar. Como afirma Salvatore Boscarino, o restauro é contemporaneamente juízo histórico-crítico e saber científico, o qual por sua vez envolve sejam conhecimentos de âmbito histórico-humanístico, sejam de natureza técnico-operativa. ${ }^{41}$

Os princípios acima relatados fazem (ou deveriam fazer) parte de qualquer intervenção em bens de valor histórico-cultural, de qualquer natureza: pinturas, esculturas, arquiteturas ou paisagens. Ainda que possa haver especificidades pertinentes a cada uma dessas áreas do fazer humano, os princípios gerais são elásticos o bastante para abarcarem-nas, não se tratando, portanto de campos específicos da restauração. Portanto, ainda que se fale comumente em restauro pictórico, restauro escultórico, restauro arquitetônico ou restauro urbano, todos são sempre restauro e, como tal, devem responder àqueles princípios gerais enunciados. A diferença consiste na linguagem e nos meios técnico-operacionais adotados na operação de restauração, que devem ser coerentes com a linguagem própria da obra a ser restaurada; assim, a pintura é usada no restauro pictórico, a escultura no restauro escultórico, a arquitetura para o restauro arquitetônico e assim por diante. No entanto, não se trata de uma livre manifestação da linguagem artística sobre a obra pré-

\footnotetext{
40 PHILIPPOT, Paul. "Le problème...", op. cit., pp. 5.

${ }^{41}$ BOSCARINO, Salvatore. Sul restauro architettonico. Saggi e note a cura di Antonella

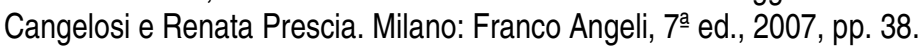


existente, mas de uma criatividade sempre subordinada ao objetivo da conservação e por este condicionada.

\section{2 - restauração arquitetônica e urbana: categorias à parte?}

O pertencimento do restauro arquitetônico e do restauro urbano ao âmbito geral da restauração deve ser frisado, dado que não são poucos aqueles que os consideram como categorias à parte. Se com o restauro arquitetônico já se delineava uma tendência de autonomia em relação ao campo da restauração em geral, alegando a especificidade da arquitetura no âmbito das artes figurativas, especialmente no que tange ao dado utilitário que é particular das edificações, ${ }^{42}$ com 0 restauro urbanístico tal tendência torna-se ainda mais incisiva. O tratamento de áreas urbanas portadoras de valor histórico ou estético é pensado por muitos profissionais apenas como problema de planejamento urbano e não como uma questão pertinente ao campo do restauro. Portanto, neste trabalho será dada especial atenção ao conceito de restauração arquitetônica e restauração urbana não por se tratarem de categorias separadas do conceito geral de restauro que se pretendeu estabelecer, mas visando justamente reafirmar tais vínculos, algo que se estende também ao atual debate das "paisagens culturais". Mas antes de passar ao desenvolvimento dessa idéia, convém apresentar um rápido resumo da gênese da noção de preservação de áreas urbanas.

Já com Gustavo Giovannoni o campo do restauro de monumentos dá passos em direção à ampliação de seu raio de alcance, preocupando-se com 0 tecido urbano e a chamada "arquitetura menor". Em sua teoria Giovannoni demonstrava a preocupação não apenas com o monumento isolado, mas com seu entorno, que deveria também ser alvo de intervenções no sentido de valorizá-lo. Semelhante preocupação se vê na Carta de Restauração de Atenas, fruto do primeiro encontro internacional de arquitetos para preservação de monumentos, no qual Giovannoni teve destacado papel.

Recomenda-se, nas resoluções da Carta de Atenas, a adoção de cuidados especiais com as proximidades dos monumentos, para que se garanta

\footnotetext{
42 No entanto, pode-se objetar que também as outras artes têm seu valor utilitário, ainda que não tão imediatamente reconhecível como no caso da arquitetura. Michele Cordaro lembra que "la valenza simbolica, devozionale, decorativa è pur essa una funzione d'uso". Ver: CORDARO, Michele. "Metodologia del restauro e progetto architettonico", In: Bollettino d'Arte, 1986, pp. 66.
} 
a preservação de "algumas perspectivas particularmente pitorescas", e no trato das massas vegetais "convenientes a determinados conjuntos de monumentos para Ihes conservar o caráter antigo".43 Também nesse documento se faz menção à poluição visual no entorno dos monumentos, que deveriam ser libertos de "toda publicidade, de toda presença abusiva de postes ou fios telegráficos, de toda indústria ruidosa, mesmo de altas chaminés, na vizinhança ou na proximidade dos monumentos de arte ou de história".44 Ademais, a apreensão com os agentes degradantes da poluição atmosférica, decorrente das "condições da vida moderna", 45 fica registrada, ainda que naquele momento não se dispusesse de estudos e meios técnicos para formulações sobre como enfrentar o problema.

Porém, a despeito do dado inovador representado pela teoria de Giovannoni e pela Carta de Atenas, o tecido urbano e a "arquitetura menor" são ainda considerados mais como "moldura" para os grandes monumentos do que como monumentos em si, com valor histórico ou estético próprios, seja individualmente, seja em conjunto. ${ }^{46}$ Sua real valorização e 0 entendimento de que poderiam ser portadores de valores memorial, documental e mesmo artístico, demoraria ainda algumas décadas para se firmar, como esclarece Renato Bonelli:

Dall'ultimo decennio dell'Ottocento questo processo si svolge in modo lento e discontinuo, e l'atenzione degli studi architettonici passa gradulmente dai monumenti principali al loro ambiente (inteso come fondale visibile), ai monumenti meno importanti, agli edifici piccoli e modesti, poi ai complessi edilizi più singolari ed ai nuclei storici meglio caratterizzati, fino a comprendere l'intera città antica. [...] Di conseguenza il restauro, in quanto operazione critica diretta all'intendimento ed alla

${ }^{43}$ Carta de Atenas (1931), In: Cartas Patrimoniais. op. cit., pp. 14.

44 Idem, Ibidem.

45 Idem, pp. 15.

46 Em seu Vecchie città ed edilizia nuova (Torino: Utet, 1931), Giovannoni trata a cidade como organismo único, que deve ser pensada de maneira unitária, evitando a oposição bairros novos $X$ bairros antigos e trabalhando as próprias áreas historicizadas de maneira orgânica, como, por exemplo, no plano que elaborou para o bairro renascentista em Roma (Proposte di sistemazione edilizia del quartiere del Rinascimento in Roma, 1916). Raíssa de Oliveira afirma que: "Giovannoni acredita na mudança de escala no urbanismo como técnica eficiente para tratar as diversas partes da cidade. É dessa forma que o componente antigo, com suas características específicas, é tratado como as outras partes da cidade, as quais também apresentam determinantes particulares". (OLIVEIRA, Raíssa Pereira Cintra de. Permanência e inovação: o antigo e o novo nos projetos urbanos de Lina Bo Bardi. São Paulo, FAU-USP, Dissertação de Mestrado, 2008, pp. 29). Porém, exemplos dessa natureza foram muito raros, e não é, de fato, a postura que transparece na Carta de Atenas, na qual fica mais evidente a idéia de "moldura" para os grandes monumentos e não um pensamento mais orgânico do fato urbano. 
conservazione, investe e comprende nel proprio campo l'intero ambiente urbano e tutta la città antica, trasformandosi in «restauro urbanistico».47

De fato, se na Carta de Atenas ainda não se tinha muita clareza no tocante ao papel que o tecido urbano exercia como bem cultural, com a Carta de Veneza tal afirmação passa a ser categórica:

A noção de monumento histórico compreende a criação arquitetônica isolada, bem como o sítio urbano ou rural que dá testemunho de uma civilização particular, de uma evolução significativa ou de um acontecimento histórico. Estende-se não só às grandes criações, mas também às obras modestas, que tenham adquirido, com o tempo, uma significação cultural. ${ }^{48}$

Ao considerar-se que um determinado conjunto arquitetônico ou parte do tecido urbano ou mesmo cidades inteiras pudessem ser alvo da atribuição de um determinado valor - seja histórico, como simples testemunho da operosidade humana, seja artístico, como exemplo daqueles especiais produtos do fazer humano a que Brandi se refere - a área da restauração adquire uma complexidade sempre crescente, o que reclama instrumentos de tutela e salvaguarda igualmente mais amplos.

Questa complessità ha determinato un dibattito particolarmente vivo e stimolante $i$ cui termini però sono tanto delicati e controversi che la nozione stessa di Restauro [...]. Infatti ora risulta molto problematico specificare la natura e l'ambito del Restauro ed è altresi difficile definirlo in maniera univoca $[\ldots]^{49}$

Tal dificuldade se nota na diversidade de abordagens possíveis no âmbito da restauração hoje. Uma dessas vertentes tende a considerar a arquitetura como produção artística de natureza diversa das artes figurativas em geral e que por isso mesmo reclamaria um tratamento de restauro distinto, com metodologia própria. Paolo Marconi é um dos autores que defende abertamente a diferenciação entre a restauração arquitetônica e 0 âmbito geral da restauração de objetos móveis. Para ele,

Si tratta di uma vera e propria differenza di statuto tra restauro architettonico e restauro di oggetti d'arte, che discende da alcuni fattore oggettivi [...]. Prima di tutto, la differenza che corre tra manufatto architettonico e manufatto "mobile" è appunto quella che il primo è immobile, e sta dove la Storia ha voluto esposto alle intemperie aggravate dalla polluzione, ai sismi ed agli insulti degli utenti [...]. Ciò impone ben

47 BONELLI, Renato. "Verbete: II Restauro Architettonico", In: Enciclopedia Universale dell'Arte. Novara, Istituto Geografico de Agostini, $4^{a}$ ed., 1983, pp. 349.

${ }^{48}$ Carta de Veneza - 1964, In: Cartas Patrimoniais, op. cit., pp. 92.

49 MIARELLI MARIANI, Gaetano. "Restauro e territorio. Appunti su un rapporto difficile e controverso", In: Centri storici. Note sul tema. Roma: Bonsignori Editore, 1993, pp. 9. 
diversi comportamenti al manufatto, in ordine alla fenomenologia del degrado e dei correlati processo conservativi. [...] In secondo luogo, la differenza che corre tra le due classi di manufatti si evidenzia anche riguardo al problema della reversibilità dei tratamenti conservativi [...].50

A vertente teórica à qual se afina Marconi, conhecida como a "hipermanutenção" ou "manutenção-repristinação", tende a considerar o restauro arquitetônico como uma categoria distinta do restauro de objetos de arte, na qual a questão da autenticidade se coloca de modo diferente. No caso de pinturas ou esculturas, o refazimento de qualquer parte danificada, ainda que pequena, implica numa falsificação da obra, já no caso da arquitetura, muito mais exposta às intempéries, a substituição de uma telha quebrada ou de uma parte do reboco não tem o mesmo caráter, e tende a ser tratada como obra de manutenção, ou seja, substituição por peças iguais, ou refazimento com as mesmas técnicas, procedimentos que se estendem também a intervenções de maior envergadura. ${ }^{51}$ Nesse caso tende-se a tratar as intervenções nos monumentos arquitetônicos como manutenções ordinárias e extraordinárias, utilizando técnicas, materiais e formas do passado, de modo a garantir uma leitura coesa $\mathrm{e}$ coerente do bem cultural, trabalhando através do que se convencionou chamar de "analogia formal", isto é,

[...] come aggiunta critica che si fonda sull'avvicinamento e sull'ascolto dell'opera lacunosa e del suo intorno. $\dot{E}$ moderna ma non indiscriminatamente creativa, sa esprimere a vista la distinzione di antico e nuovo ma, insieme, mira a dare o conservare unità architettonica al manufatto. ${ }^{52}$

Para Paolo Marconi,

Il fatto è che ragionare e operare considerando inseparabile il binomio conservazione-autenticità è certo importante per i mercanti d'arte e i loro consulenti. Non lo è altrettanto, se non è addirittura contraproducente, nel caso dei monumenti architettonici, nei quali addirittura una certa dosi di inautenticità può talvolta rafforzare e dar senso all'insieme altrimenti troppo lacunoso. ${ }^{53}$

Marconi defende que nem os monumentos arquitetônicos, nem os contextos urbanos se conservam iguais ao longo do tempo, mas sofrem inúmeras transformações, seja de uso, seja morfológica. Assim, devem ser

50 MARCONI, Paolo. "Conoscenza storica e progetto", In: Bollettino d'Arte, 1986, pp. 60.

${ }^{51} \mathrm{KÜHL}$, Beatriz Mugayar. Preservação da Arquitetura Industrial em São Paulo: questões teóricas. São Paulo, FAUUSP, Relatório Científico (auxílio à pesquisa FAPESP), não publicado, jun. 2005, pp. 65.

52 CARBONARA, Giovanni. "Architettura e restauro...", op. cit., pp. 105.

53 MARCONI, Paolo. Materia e significato. La questione del restauro architettonico. Roma-Bari: Laterza, 2003, pp. 3. Grifos do autor. 
induzidas outras transformações em sentido contrário, a fim de restabelecer a unidade semântica do contexto, visando transmitir ao futuro seus significados, separando, portanto, os procedimentos relativos à conservação da arquitetura, paisagens e áreas urbanas daqueles a serem adotados para os objetos de arte móveis. $^{54}$

Contrariando essa idéia, Michele Cordaro afirma que:

Le uniche differenze dunque che possono istituirsi tra l'architettura e altri tipi di manufatti di interesse storico e artistico, dal punto di vista della manutenzione, della conservazione e del restauro, non riguardando contrapposizioni di teoria o di impostazione metodologica generale, bensì unicamente gli aspetti concreti della tecnologia degli interventi. [...] II manufatto architettonico, per la sua stessa natura, è sicuramente più esposto a rischi simili di quanto non lo sia un dipinto o qualsiasi altro manufatto conservato in un museo o comunque in uno spazio interno. Da qui deriverebbe la necessità di distinguere ciò che può essere funzionale per la conservazione di una pittura da quello che invece è necessario realizzare per la conservazione di un'architettura, soprattuto per la sua struttura e decorazione d'esterno. II problema esiste. Ma occorre approfondirlo per trovare l'ambito di ricerca in grado di ricomporlo ad unità di metodo. 55

Trata-se, portanto, de uma diferenciação na tecnologia adotada, procurando aquela que é a mais adequada e pertinente em cada situação específica de restauro seja de arquitetura, de pintura ou de escultura, sem, contudo, separá-las em categorias diversas, dado que 0 fundamento metodológico é sempre aquele do restauro em geral. No caso da restauração de arquitetura, portanto, o restaurador deve ser um arquiteto capaz de expressar-se através de um projeto de arquitetura, mas consciente de que não se trata de um projeto personalista que se faz a despeito da pré-existência, mas com parâmetros oferecidos pelo próprio campo disciplinar da restauração, como afirma La Regina:

[...] se il restauro appartiene alla cultura architettonica, allora l'architetto che svolge tale attività deve acquisire tutte le competenze indispensabili per condurre a buon esito il suo lavoro, ma deve anche coraggiosamente assumersi le proprie responsabilità di progettista ed operare nella consapevolezza che ogni nuovo innesto sulla preesistenza è un segno culturalmente significativo che lascia la sua traccia su un terreno già tracciatto dalla storia. 56

Igualmente o restauro urbanístico não significa um novo método operacional, mas é conseqüência de uma ampliação de escala que advém do

54 TORSELLO, B. Paolo et alli, op. cit., pp. 45.

${ }^{55}$ CORDARO, Michele. "Metodologia...", op. cit., pp. 66-67.

${ }^{56}$ LA REGINA, Francesco. "Introduzione", In: PALMIERI, Antonella (a cura di). Restauro e progetto. Napoli: Electa, 1991, pp. 9. 
próprio juízo crítico, que habilita o restaurador a delimitar os valores presentes, seja no monumento individual (isto é, obra de arte como expressão de uma linguagem), seja nos conjuntos urbanos (testemunho do fazer humano em um determinado espaço e tempo). A partir desta primeira operação de reconhecimento dos valores em causa, passa-se às ações subseqüentes, por ela condicionadas. Portanto, "le attività propie del Restauro territoriale consistono nel determinare $i$ modi idonei a garantire la conservazione dei valori identificati nell'ambiente, in vista della loro trasmissione al futuro". ${ }^{57}$

A restauração do território não pode seguir critérios distintos daqueles já postos pela restauração de monumentos, dado que a ação de restauro (independentemente de qual tipo de bem cultural se trate) tem sua razão e sua legitimidade a partir do reconhecimento de que a obra é portadora de um valor. Dessa forma, não se pode pensar a intervenção senão baseada num juízo crítico,

cioè sopra uma definizione oggetiva che colga il valore precipuo della preesistenza, vale a dire ne operi il riconoscimento, attraverso criteri e metri interni all'opera stessa. [...] Un metodo quindi che è, con tutta evidenza, caratteristico del Restauro dei Monumenti.58

Gaetano Miarelli Mariani propõe um olhar sobre a cidade como um todo, como grande organismo histórico carregado de diferentes temporalidades, para uma melhor compreensão do centro histórico. ${ }^{59}$ Reconhece, entretanto, que nem tudo que existe, ainda que localizado em áreas históricas, deva ser conservado, o que coloca duas possibilidades de intervenção sobre uma preexistência: uma conservativa e outra não-conservativa. Novamente o que guiará a escolha sobre a forma mais adequada de intervir é o juízo crítico: se o objeto é portador de valor histórico ou ambiental, deve-se excluir de antemão qualquer intervenção que não siga os pressupostos dados pelo restauro, visando transmitir esses valores ao futuro. ${ }^{60}$ Ainda que se deva pensar na necessidade de adequar as edificações antigas aos usos contemporâneos, fundamentais para sua manutenção como parte integrante da dinâmica urbana, esta adequação não pode ser feita de maneira descuidada e irresponsável, impondo-se valores de natureza utilitária, econômica ou política sobre os valores memoriais e referenciais da arquitetura e ambientes do passado. Sobre a questão da

${ }^{57}$ MIARELLI MARIANI, Gaetano. Op. cit., pp. 16.

58 Idem, ibidem.

59 Idem, pp. 42.

60 Idem, pp. 55-56. 
(re)utilização das arquiteturas do passado, tendo em vista a importância do tema nas discussões sobre a preservação de monumentos, se falará adiante de modo mais detido. 0 que se deseja por hora é apenas ressaltar que, quando se fala em restauração urbana, se trata de uma ampliação conceitual e não de uma completa transformação no conceito de patrimônio. Desse modo, deve-se frisar que todos os postulados e indicações metodológicas de intervenção para os monumentos arquitetônicos e para o tecido urbano derivam daquilo que se disse em relação aos monumentos em geral, isto é, seguindo um mesmo desenvolvimento teórico-metodológico e não como campo de pesquisas à parte.

\section{3 - restauração $X$ conservação}

Alguns autores defendem que restauro e conservação, longe de serem sinônimos ou formas de intervenção complementares, sejam atividades de natureza distinta e com desenvolvimento histórico igualmente diferenciado. Principalmente para aqueles teóricos ligados à corrente conhecida como "conservação integral" ou "pura conservação" a história da restauração coincide com a história da deturpação dos monumentos, que são irremediavelmente alterados com as intervenções executadas, na qual os valores formais se colocam acima daqueles de natureza matérica. Para Dezzi Bardeschi, um dos baluartes da "conservação integral", as atenções concentradas mais sobre a imagem do que sobre a cultura material que a produziu, valorizando mais a aparência visível do que a consistência da obra, ocasionam a alteração e, portanto, a destruição dos valores materiais, identificado pelo autor como "quell'unicum non riproducibile che è l'essenza stessa dell'opera architettonica". ${ }^{61}$

No início deste capítulo fez-se um breve aceno ao (anti)conceito de restauro elaborado por John Ruskin em meados do século XIX, o qual identificava a restauração como a mais completa destruição que pudesse se abater sobre um dado monumento histórico. ${ }^{62}$

Lançando um rápido olhar sobre o cenário inglês daquele momento torna-se mais clara a compreensão da radical assertiva ruskiniana. De fato, a restauração tal como praticada até aquele momento na Inglaterra acarretava mais danos do que efetivamente preservação nas obras sobre as quais incidia.

61 DEZZI BARDESCHI, Marco. Restauro: punto e da capo..., op. cit., pp. 42.

62 Tal como explicitado pelo aforisma 31 de seu "A lâmpada da memória", apresentado na nota 7 deste capítulo. 
Inúmeras vozes naquele período, juntamente com Ruskin, se levantavam contra a onda de radicais transformações impostas pelas intervenções de restauro em curso nas cidades e, especialmente, nas igrejas inglesas, dando origem ao que se convencionou chamar de Anti-Scrape Moviment ou Movimento AntiRestauração.

Em finais do século XVIII importantes igrejas da Grã-Bretanha, que haviam sofrido saques e depauperação durante a Reforma Protestante, passam por intervenções empreendidas pelo arquiteto James Wyatt, o qual, em nome do rigor da proporção e da ordem clássicas, eliminava partes dos monumentos, acrescentando outras novas, adulterando aspectos originais das obras em favor de elementos pseudo-históricos. Em razão das profundas alterações que Wyatt impunha aos monumentos, ele "era considerado por alguns o Palladio da Inglaterra, sendo chamado por outros de Wyatt 0 destruidor".63 Apesar das críticas, Wyatt teve numerosos seguidores, dentre os quais sir George Gilbert Scott, "responsável por várias transformações e readaptações de edifícios, [0 qual] tendo exercido grande influência em sua época [...] participou de numerosas restaurações de catedrais, por vezes consideradas abusivas". ${ }^{64}$

No livro Principles of Church Restoration, publicado em 1846, Edward Augustus Freeman apresentava basicamente três modalidades de intervenção para a restauração de igrejas: 1) restauro destrutivo, que coincidia com a reconstrução integral da obra, preferencialmente adotando o "melhor" de seu estilo como paradigma; 2) restauro eclético, que continua a ser reconstrução da obra, mas aceitando a diversidade de estilos que a conformam, sem buscar uma unidade estilística; 3) restauro conservativo, identificado como a substituição de partes deterioradas por novas peças, executadas com novos materiais porém idênticas às peças originais, visando a manutenção da forma do monumento. ${ }^{65}$

Em qualquer uma das três modalidades acima apresentadas, bem como a partir dos resultados das intervenções de Wyatt e de seus seguidores, fica patente que a forma de tratamento dispensada aos monumentos naquele momento identifica-se com a idéia de melhoramento da obra original e não com a preservação dos elementos que a constituíram historicamente. Mais importante do que a matéria historicizada era a preservação de uma dada imagem, muitas

63 PINHEIRO, Maria Lucia Bressan. "William Morris e a SPAB", In: Rotunda, Campinas, n. 3, outubro 2004, pp. 24.

${ }^{64}$ KÜHL, Beatriz Mugayar. "Notas sobre...", op. cit., pp. 192.

65 JOKILEHTO, Jukka. Op. cit., pp. 301 e ss. 
vezes idealizada e distinta de qualquer aspecto que o bem arquitetônico possa realmente ter havido em seu devir histórico. Portanto,

Denunciare il carattere distruttivo del restauro è un modo, l'unico possibile in quel momento, di opporsi alla manipolazione e stravolgimento del patrimonio costruito e di porre le basi per una nuova metodologia d'intervento, fondata su alcuni, basilari e inderogabili principi: 1) sostituire al restauro l'attività di manutenzione costante e sistematica [...]; 2) limitare gli interventi a provvedimenti tecnici "esterni" all'opera, anchorché deturpanti, purché distinguibili e possibilmente provvisionali [...]; 3) diffondere nella società una nuova sensibilità in materia, una cultura dell'interesse e del rispetto per le testemonianze del passato [...]. ${ }^{66}$

Esse incômodo em relação à forma extremamente intervencionista dos restauros praticados até então em ambiente inglês não se limita a John Ruskin. Outros arquitetos e pensadores ingleses, tal como William Morris, dão continuidade à militância de Ruskin em suas denúncias e na condenação da restauração como atividade falsificadora e destruidora da memória.

No ano de 1877, o arquiteto e designer William Morris é o responsável pela criação da Society for the Preservation of Ancient Buildings - SPAB cujo Manifesto escrito pelo próprio Morris trazia como principais pontos: 0 reconhecimento de que nos últimos 50 anos assistiu-se ao alvorecer de um crescente interesse em relação aos antigos monumentos, mas que, paradoxalmente, tal interesse trouxe mais destruição do que séculos de revoluções; uma "estranha idéia de restauração" existente nesse momento impunha às arquiteturas antigas modificações inaceitáveis, baseada na moda $\mathrm{e}$ nos gostos contemporâneos, cancelando sua historicidade; chama a atenção para a necessidade de valorização de qualquer manifestação histórica e não apenas de um determinado período ou estilo arquitetônico; advoga pela substituição da restauração (tal como explicitada até o momento) em favor da tutela e da conservação, como ação cotidiana de manutenção. ${ }^{67}$

O Movimento Anti-Restauração contará com campanhas de denúncia de intervenções consideradas abusivas em várias partes do mundo, através da ação do Foreign Committee da SPAB.$^{68}$ Um exemplo é a campanha do ano de

${ }^{6}$ LA REGINA, Francesco. "John Ruskin (1819-1900)", In: TORSELLO, B. Paolo et alli, op. cit., pp. 106.

67 MORRIS, William. "The Manifesto of the SPAB", disponivel em: http://www.spab.org.uk/what-is-spab-/the-manifestol. Acesso em: 26 nov. 2009, 17:29.

68 DE MARTINO, Riccardo. "William Morris e la 'protezione dei monumenti", In: CASIELLO, Stella (a cura di). La cultura del restauro. Teorie e fondatori. Venezia: Marsilio, $3^{\underline{a}}$ edizione, 2005, pp. 156. 
1879, referente às obras na Basílica de São Marcos em Veneza, ${ }^{69}$ na qual se destaca a noção de que os edifícios de uma determinada Nação não the pertencem, antes pertencem à humanidade como um todo, sendo bem comum $\mathrm{e}$ universal, antecipando uma idéia que se estabelecerá definitivamente praticamente cem anos depois, em 1972, com a criação da Convenção do Patrimônio Mundial, organismo pertencente à UNESCO.

Porém, não apenas da Inglaterra partiam críticas às intervenções descaracterizadoras. Na própria França, terra-natal de Viollet-le-Duc e do chamado restauro estilístico, já se faziam sentir algumas vozes dissonantes, tais como a de Adolphe Didron, que afirmava no ano de 1845: "No que tange aos monumentos antigos, é melhor consolidar do que reparar, reparar do que restaurar, restaurar do que refazer, refazer do que embelezar; em nenhum caso se deve acrescentar e, sobretudo, nada suprimir" ${ }^{70}$

Essa máxima de Didron foi retomada pelo italiano Camillo Boito, ainda que não de modo explícito, dado seu papel como protagonista do Congresso de Engenheiros e Arquitetos Italianos, realizado em Roma no ano de 1883, no qual se estabeleceu como critérios a serem seguidos nas intervenções em monumentos do passado as seguintes recomendações:

1. I monumenti architettonici, quando sia dimostrata incontrastabilmente la necessità di porvi mano, devono piuttosto venire consolidati che riparati, piuttosto riparati che restaurati, evitando in essi con ogni studio le aggiunte e le rinnovazioni.

2. Nel caso che le dette aggiunte o rinnovazioni tornino assolutamente indispensabili per la solidità o per altre cause invincibili, e nel caso che riguardino parti non mai esistite o non più esistenti e per le quali manchi la conoscenza sicura della forma primitiva, le aggiunte o rinnovazioni si devono compiere con carattere diverso da quello del monumento, avvertendo che, possibilmente, nell'apparenza prospettica le nuove forme non urtino troppo con il suo aspetto artistico.

69 DI BIASE, Carolina. "Camillo Boito", In: CASIELLO, Stella (a cura di). La cultura..., op. cit., pp. 165.

70 Adolphe Didron, apud KÜHL, Beatriz Mugayar. "A restauração de monumentos históricos na França após a Revolução Francesa e durante o século XIX: um período crucial para o amadurecimento teórico", In: Revista CPC, São Paulo, n. 3, nov. 2006/abr. 2007, pp. 125. Sobre as críticas ao restauro estilístico, Antón Capitel escreve: "Pero la posición radical de Ruskin frente a cualquiera que fuere la restauración de la arquitectura pasada y, concretamente, frente a la restauración en estilo, no fue excepción, sino un cierto estado de opinión entre algunos literatos e intelectuales. Ya en vida de Viollet su obra y sus ideas fueron ampliamente contestadas, aumentando las críticas a su muerte" (CAPITEL, Antón. Metamorfosis de monumentos y teorías de la restauración. Madrid: Alianza Forma, 1992, pp. 26). 
3. Quando si tratti invece di compiere cose distrutte o non ultimate in origine per fortuite cagioni, oppure di rifare parti tanto deperite da non poter più durare in opera, e quando non di meno rimanga il tipo vecchio da riprodurre con precisione, allora converrà in ogni modo che i pezzi aggiunti o rinnovati, pure assumendo la forma primitiva, siano di materia evidentemente diversa, o portino un segno inciso o meglio la data del restauro, sicché neanche su ciò possa l'attento osservatore venire tratto in inganno. Nei monumenti dell'antichità 0 in altri, ove sia notevole la importanza propriamente archeologica, le parti di compimento indispensabili alla solidità e alla conservazione dovrebbero essere lasciate coi soli piani semplici e coi soli solidi geometrici dell'abbozzo, anche quando non appariscano altro che la continuazione od il sicuro riscontro di altre parti anche sagomate ed ornate.

4. Nei monumenti, che traggono la bellezza, la singolarità, la poesia del loro aspetto dalla varietà dei marmi, dei mosaici, dei dipinti oppure dal colore della loro vecchiezza o delle circostanze pittoresche in cui si trovano, o perfino dallo stato rovinoso in cui giacciono, le opere di consolidamento, ridotte allo strettissimo indispensabile, non dovranno scemare possibilmente in nulla coteste ragioni intrinseche ed estrinseche di allettamento artistico.

5. Saranno considerate per monumenti, e trattate come tali, quelle aggiunte o modificazioni che in diverse tempi fossero state introdotte nell'edificio primitivo, salvo il caso in cui, avendo un'importanza artistica e storica manifestamente minore dell'edificio stesso e nel medesimo tempo svisando e smascherando alcune parti notevoli di esso, si ha da consigliare la rimozione o la distruzione. In tutti i casi nei quali riesca possibile, o ne valga la spesa, le opere di cui si parla verranno serbate, o nel loro insieme 0 in alcune parti essenziali, possibilmente accanto al monumento da cui furono rimosse.

6. Dovranno eseguirsi, innanzi di por mano ad opere anche piccole di riparazione o di restauro, le fotografie del monumento, poi di mano in mano le fotografie dei principali periodi del lavoro, e finalmente le fotografie del lavoro compiuto. Questa serie di fotografie sarà trasmessa al Ministero della Pubblica Istruzione insieme con i disegni delle piante degli alzati e dei dettagli e, occorrendo, cogli acquarelli colorati, ove figurino con evidente chiarezza tutte le opere conservate, consolidate, rifatte, rinnovate, modificate, rimosse o distrutte. Un resoconto preciso e metodico delle ragioni e del procedimento delle opere e delle variazioni di ogni specie accompagnerà i disegni e le fotografie. Una copia di tutti $i$ documenti ora indicati dovrà rimanere depositata presso le fabbricerie delle chiese restaurate, o presso l'ufficio cui spetta la custodia del monumento.

7. Una lapide da infiggere nel monumento restaurato ricorderà la data e le opere principali del restauro. ${ }^{71}$

Ainda que o percurso de Boito como restaurador não tenha sido linear ou coerente, muitos autores apontam para a importância de sua reflexão no campo disciplinar do restauro, que se traduz numa metodologia inegavelmente

71 Voto Conclusivo del III Congresso degli Ingegneri e Architetti Italiani, Roma, 1883. Apud: CARBONARA, Giovanni. Avvicinamento..., op. cit., pp. 209-210. Grifo nosso, destacando a semelhança com a assertiva de Didron. 
mais respeitosa e ponderada frente aos excessos do restauro estilístico e das maciças recomposições usuais naquele período e mesmo em épocas mais recentes. Como se pode notar a partir das recomendações apresentadas acima, a restauração é considerada como atividade a ser evitada ou postergada através da consolidação e de reparos constantes. Quando for necessário providenciar reforços estruturais ou adições de qualquer natureza (com uma função ou justificativa e não pela simples vontade do restaurador, deve-se enfatizar), estas devem ter um caráter visivelmente distinto do original. Ademais, preconiza-se a documentação detalhada de todos os trabalhos executados.

A postura boitiana é encarada, principalmente pelos teóricos ligados à "conservação integral", como um desenvolvimento dos ideais anti-restauração dos ingleses, num movimento crescente rumo à conservação, em detrimento do restauro, definido como obra de destruição da autenticidade material dos monumentos históricos. ${ }^{72}$ Giovanni Carbonara, por sua vez, alerta para o fato de que, mais do que renovar a teoria do restauro nas últimas décadas do século XIX, Camillo Boito foi responsável pela reorganização e sistematização de postulados e preceitos já existentes na cultura do restauro desde finais dos setecentos até àquele momento, retomando e reforçando a necessidade de se operar através da mínima intervenção, da distinguibilidade e da reversibilidade. ${ }^{73}$ Se se deseja pensar em Boito como antecipador de tendências teóricas no campo da restauração, muito mais do que "pai" da "conservação integral", podese identificar em suas proposições alguns aspectos embrionários do que viria a ser o restauro crítico e a teoria brandiana no aspecto relacionado com a necessidade de contrabalançar a dialética estética-história inerente a toda intervenção restauradora, tal como colocado no quinto tópico do Voto Conclusivo do Congresso de Engenheiros e Arquitetos. ${ }^{74}$

72 Essa visão pode ser notada especialmente em Amedeo Bellini e Marco Dezzi Bardeschi, do qual se destaca: DEZZI BARDESCHI, Marco. "Quarant'anni di restauri a Milano tra teorie e pratica", In: Ananke, n. 50-51, Firenze: Alinea Editrice, 2007, pp. 150 e ss. Porém, em seu texto Os Restauradores, Camillo Boito lança uma sólida base para um restauro fundamentado, procurando "domesticar" a fúria intervencionista do período, mas de modo algum negando a necessidade e legitimidade do restauro, desde que devidamente embasado. 0 autor, inclusive denomina de "lógica impiedosa" a postura anti-intervencionista que alimenta o movimento Anti-Restauração inglês. Vide: BOITO, Camillo. Os Restauradores. São Paulo: Ateliê Editorial, 2002, pp. 57.

${ }^{73}$ CARBONARA, Giovanni. Avvicinamento..., op. cit., pp. 207-208, nota 12.

74 Idem, ibidem. E também: TORSELLO, B. Paolo. Restauro architettonico..., op. cit., pp. 57 , nota 12. 
De certo modo, escamoteando as contradições presentes no pensamento boitiano, enfatizando sua postura conservacionista, considerada como descendente dos pressupostos estabelecidos pelo Movimento AntiRestauração, os defensores da "conservação integral" se colocam numa posição de continuadores desse legado. Para eles uma atenta manutenção deveria substituir a restauração, posto que

[...] ogni operazione di restauro, quando sia condotta tardivamente su un organismo edilizio notevolmente degradato, scarica una inammissibile violenza sul contesto fisico che si vorrebbe salvaguardare, si traduce cioè in un intervento traumatico il cui risultato perverso è proprio quello paradossalmente - di sottrarre materia all'opera che invece si vorrebbe preservare dall'autodistruzione. ${ }^{75}$

A manutenção constante seria, portanto, um antídoto contra a restauração - operação de caráter traumático a ser evitada ou postergada 0 quanto possível. Essa mesma visão já estava presente na Carta de Veneza, de 1964, na qual a conservação preventiva se apresenta como forma de evitar a restauração, entendida como ato de caráter excepcional. ${ }^{76}$

Ainda que defenda a conservação e manutenção constante dos bens culturais, para Cesare Brandi isto já se constitui num ato de restauração a pleno título e, dessa maneira, comporta os mesmos princípios apresentados para 0 restauro "de fato", tanto que Brandi nomeia esta ação de restauração preventiva e não de conservação ou manutenção. ${ }^{77}$ Por restauro preventivo, no âmbito da teoria brandiana, considera-se "qualquer providência voltada a assegurar no futuro a conservação da obra de arte como imagem e como matéria, a que está vinculada a imagem" ${ }^{78}$ Disto, conclui Brandi, resulta que

[...] é só a título prático que se distingue uma restauração preventiva de uma restauração efetiva [...] porque tanto uma como outra valem pelo único e indivisivel imperativo que a consciência impõe a si no ato do reconhecimento da obra de arte na sua dúplice polaridade estética e histórica e que leva à sua salvaguarda como imagem e como matéria. ${ }^{79}$

Portanto, a restauração preventiva se refere à noção de tutela em sua complexidade, incluindo ações de prevenção ou minimização de danos, controle de situação ambiental de modo a evitar conjunturas que possam acelerar o processo de degradação da obra, limpezas e consolidações periódicas e

75 DEZZI BARDESCHI, Marco. Restauro: punto e da capo..., op. cit., pp. 71.

${ }^{76}$ Carta de Veneza, In: Cartas Patrimoniais, op. cit., pp. 93.

77 BRANDI, Cesare. Op. cit., pp. 101.

78 Idem, ibidem.

79 Idem, ibidem. 
também as questões relativas à fruição do monumento, tudo isto sem cair no erro de "fare manutenzione e prevenzione rimuovendo le implicazioni critiche che il restauro, in quanto tale, comporta e rifugiandosi nell'alveo, in fin dei conti più rassicurante, delle esclusive competenze 'tecniche"”. ${ }^{80}$ Ao colocar a restauração preventiva como ato de restauro a pleno título, Brandi submete-a aos compromissos daí resultantes, isto é, equilibrar através das escolhas efetuadas a dúplice polaridade estética e histórica da obra sobre a qual se intervém. Destacase, portanto, a extensão dos cuidados para o ambiente ou entorno da obra como forma de garantir sua adequada conservação física e também sua leitura como obra de arte, conceito presente não apenas em Brandi, como também na Carta de Veneza. Especialmente no tocante à arquitetura, deve-se ter cuidado redobrado em intervenções nas proximidades de monumentos, posto que, ainda que materialmente não se altere diretamente a obra, figurativamente pode-se modificá-la substancialmente, como afirma Brandi evocando o exemplo da abertura do Corso del Rinascimento em Roma, que, embora não tenha tocado a igreja Sant'Andrea della Valle, acarretou modificações profundas na forma de aproximação e, portanto, de percepção desta obra. ${ }^{81}$ Dessa forma, para Brandi a restauração preventiva na arquitetura diz respeito ao estabelecimento da "intangibilidade das zonas adjacentes" aos monumentos. ${ }^{82}$

Com 0 agravamento da poluição atmosférica e outras transformações nas condições ambientais que se verificam no ambiente contemporâneo, seja ele urbano ou mesmo rural, a supervisão constante do estado de conservação dos monumentos é uma tarefa ainda mais necessária e cuidados com sua limpeza e manutenção periódica são igualmente vitais para a efetiva salvaguarda das obras herdadas do passado e que se deseja transmitir ao futuro. Porém, deve-se ter em mente que nenhuma ação sobre bens culturais é incólume e pode passar despercebida, até mesmo uma simples limpeza potencialmente acarreta substanciais modificações na imagem da obra e, conseqüentemente, em sua percepção. Diante disto, reafirma-se aqui a importância de, ao se estabelecerem programas de manutenção e conservação preventiva, ter em mente que se trata sempre de um ato de restauração, o qual implica na adoção de uma metodologia

80 CARBONARA, Giovanni. Avvicinamento..., op. cit., pp. 315.

81 BRANDI, Cesare. Op. cit., pp. 105-106. Para este caso, remete-se ainda aos comentários de Michele Cordaro: CORDARO, Michele. "Restauro e tutela...", op. cit., pp. 70-71. E igualmente, de Giovanni Carbonara: CARBONARA, Giovanni. La reintegrazione dellimagine. Roma: Bulzoni, 1976, pp. 94.

82 BRANDI, Cesare. Op. cit., pp. 106. 
filológica e científica a indagar a autenticidade da obra de arte e a sua consistência material, para daí definir a mais conveniente estratégia de intervenção, caso a caso.

A oposição do binômio conservação/restauração no âmbito deste trabalho e dos conceitos até o momento expostos parece não apenas infrutífera, como também insustentável, na medida em que se crê, em conformidade com a afirmação de Giovanni Carbonara que:

II restauro corretamente inteso, in base all'attuale livello della nostra cultura storico-critica, ha proprio funzione conservativa, perciò non ha senso la dizione tanto diffusa quanto ingiustificata di "restauro conservativo" (non potendosi ipotizzare alcun restauro che sia veramente tale $e$ che non punti, con tutte le sue forze, alla perpetuazione dell'oggetto, né alcun restauro, degno di questo nome, che sia volutamente "distruttivo" e non si ponga invece fini di conservazione). ${ }^{83}$

\section{4 - restauração: diversidade de meios e convergência de fins}

Até o momento procurou-se evidenciar que a restauração, como campo disciplinar, está em constante amadurecimento e reflexão. Não se tratando, portanto, de um percurso de desenvolvimento ou evolução, com sentido linear ou teleológico, mas de um processo histórico complexo no qual diversas idéias convivem, algumas confluentes, outras contrastantes. ${ }^{84}$

Apesar dessa diversidade de abordagens possíveis, não se pode desconsiderar todo conhecimento acumulado ao longo de pelo menos dois séculos de história do restauro, ignorando transformações e revisões da matéria, seja do ponto de vista prático, seja teórico. Não se pretende defender aqui a adoção cega a uma ou outra corrente teórica da restauração, mas ressaltar a importância capital que o conhecimento e a reflexão sobre tais teorias têm para aqueles que se dispõem a intervir sobre os monumentos do passado, tendo em vista a responsabilidade social que uma tal atividade comporta.

Oggi il compito è di sommare le nostre esperienze a quelle della generazione precedente, senza disperderne gli utili apporti e senza creare artificiose contrapposizioni. Si tratta d'impegnarsi a fondo per attuare una seria volontà conservativa, e di struttura e d'immagine; 85

${ }^{83}$ CARBONARA, Giovanni (diretto da). Trattato di Restauro..., op. cit., pp. 91.

84 PHILIPPOT, Paul. Saggi sul restauro e dintorni. Antologia. Roma: Bonsignori Editore, 1998, pp. 101.

${ }^{85}$ CARBONARA, Giovanni. "Restauro fra conservazione e ripristino: note sui più attuali orientamenti di metodo", In: Palladio. Nuova Serie, n. 3, 1990, pp. 72. 
Aceitando como inerente à noção ocidental de monumento 0 fato de que cada obra é única e insubstituível em sua conformação e devir no tempo, não se pode agir nesse campo de modo descuidado ou irresponsável. Qualquer perda nessa área significa uma perda irrecuperável, e qualquer substituição não pode ser feita se não por meio de uma falsificação, dado que é impossível retroceder no tempo. De onde descende a exigência de agir sempre com prudência e respeito à realidade material da obra a ser restaurada, garantindo meios técnicos idôneos e compatíveis com essa materialidade, em modo claramente distinguível e, quanto possível, reversível. Não sendo admitidas, senão à custa de severos danos à obra que se pretende conservar, aplicações automáticas de fórmulas prontas, como se o restauro fosse ação de natureza unicamente técnica e não primeiramente um problema de natureza históricocrítica a ser resolvido.

A propósito da relação entre conhecimento técnico e princípios teóricos, Giovanni Carbonara acena como seja

[...] molto curioso che due scuole di pensiero radicalmente diverse come quella, d'impronta milanese, della "pura conservazione" o della "conservazione integrale", e l'altra della "manutenzione-ripristino", muovano entrambe da una comune esigenza di studio diretto e autoptico della fabbrica, per poi divergere nei loro esiti: in un caso verso la conservazione, corroborata proprio dalla conoscenza, di ogni traccia, trasformazione o stratificazione, nell'altro per piegare quella stessa conoscenza verso la riproduzione e la simulazione architettonica. È interessante tale inopinata biforcazione, perchè dimostra che il nodo concettuale non sta nella conoscenza o nelle sue modalità ma nell'uso che di essa si fa, quindi nella mediazione teoretica, che apre una strada o l'altra, o forse un'altra ancora, quella che noi chiamiamo "criticoconservativa". 86

Se o ponto central não é o conhecimento, mas a mediação teórica, isto é, a forma como cada profissional ou equipe se apropria deste conhecimento para então passar à atividade prática, chama-se, portanto, à responsabilidade 0 arquiteto-restaurador, o qual deve agir dando respostas práticas às demandas postas pela variada casuística de maneira responsável e coerente, dado que não se trata simplesmente de decisões de natureza técnica, suscitadas por estudos e análises científicas, mas sempre de uma complexa questão, primeiramente crítica e cultural, a ser sabia e sensivelmente enfrentada.

${ }^{86}$ LUMIA, Chiara. A proposito del restauro e della conservazione. Roma: Gangemi Editore, 2003, pp. 43. 
A partir de agora serão sucintamente apresentados os variados meios que podem ser utilizados para a conservação de uma arquitetura ou paisagem histórica, sempre enquadrados dentro do campo disciplinar da restauração, ao qual "il restauro architettonico appartiene [...] e quindi, come quello pittorico, scultorico, archeologico fa parte di quella scienza autonoma, che ha una propria base teorica unitaria, una propria metodologia e una propria tecnica". ${ }^{87}$

No início deste capítulo já se acenava para a importância do conhecimento detalhado como ponto de partida para a restauração, assim como advertia Umberto Baldini. Portanto, o primeiro ponto a ser destacado é, sem dúvida, a necessidade de um conhecimento profundo do objeto sobre o qual se deve intervir. Tal conhecimento deve ser anterior à própria intervenção, ainda que se tenha consciência de que ele nunca será completo e definitivo e que, certamente, durante a intervenção propriamente dita, novas descobertas se darão. Sem esse primeiro contato com a obra, anterior ao restauro, corre-se 0 risco de empreender um caminho baseado em noções pré-concebidas, as quais podem se mostrar equivocadas num segundo momento. De fato uma análise superficial ou parcial do monumento pode levar a erros de leitura e interpretação das técnicas construtivas, das reais condições de degradação da obra, dos diversos momentos históricos que marcaram seu devir no tempo, bem como de seus valores e significados.

Sul piano pratico [del restauro], si assiste troppo spesso ad un'elusione della diagnosi critica a cui si sostituisce l'ingannevole illusione d'una evidenza che non é altro che la proiezione, sull'oggetto mal conosciuto, del gusto o delle concezioni del restauratore disinformato, a meno che non si tratti, più semplicemente ancora, dell'applicazione automatica di tecniche correnti senz'alcuna preventiva definizione del problema critico. $^{88}$

Diversos são os meios para um amplo conhecimento do bem cultural sobre 0 qual se intervém: alguns se referem à pesquisa direta sobre 0 monumento e o que ele próprio "diz" de sua condição, tal como a estratigrafia, prospecções, levantamento métrico-arquitetônico, análise dos materiais e de suas patologias, etc; outras ações, ao contrário, referem-se aos levantamentos e estudos indiretos, a exemplo da pesquisa de fontes históricas, da pesquisa iconográfica, do levantamento de projetos de reforma sucessivas à conclusão da obra e de eventuais restaurações anteriormente executadas. Essas duas etapas,

${ }^{87}$ BOSCARINO, Salvatore. Op. cit., pp. 87.

88 PHILIPPOT, Paul. "Storia e attualità del restauro", In: Saggi sul restauro e dintorni. Antologia. A cura di Paolo Fancelli. Roma; Bonsignori, 1998, pp. 103. 
a de estudos diretos e a de estudos indiretos do bem cultural, devem ser cumpridas e têm caráter complementar e solidário.

Com relação ao estudo diretamente sobre o monumento, deve-se frisar que uma visão muito genérica não se coaduna com a escala de intervenção quando se fala em restauro, posto que cada patologia, cada problema estrutural, etc, demandam soluções particulares e específicas. Numa mesma fachada, feita com os mesmos materiais, as patologias podem ser de diferentes naturezas e, portanto, demandar uma profilaxia igualmente diversa de uma parte para outra. Portanto, quando se refere à restauração, a escala de trabalho para os levantamentos não é a mesma de um projeto arquitetônico comum, mas deve ser muito mais detalhada, como define Giorgio Torraca: centimétrica. ${ }^{89}$

O conjunto de dados levantados, através de um cuidadoso trabalho multidisciplinar, dará ao restaurador maior segurança nas decisões projetuais, tornando a operação de restauro mais eficaz e menos deturpadora através dos parâmetros oferecidos pela atenta análise da obra e suas reais necessidades. Porém, deve-se advertir para alguns riscos: o primeiro deles diz respeito a uma visão pragmática e utilitarista no tratamento desses dados, mais ou menos como fazia Viollet-le-Duc, ${ }^{90} 0$ qual acreditava que o conhecimento aprofundado daria autoridade e inquestionabilidade ao ato de intervenção. A fortuna crítica da obra de Viollet-le-Duc como restaurador, as inúmeras críticas levantadas já desde 0 século XIX à sua forma de intervir, podem dar uma idéia do equívoco que tal postura traz e dos riscos dela decorrentes. Um segundo risco diz respeito à multidisciplinaridade. $\mathrm{O}$ fato de ter dados oriundos de diversas disciplinas, tais como a química, a física e a história, pode gerar a ilusão de estar garantida a desejável multidisciplinaridade no processo de restauração. Se tais estudos forem tratados como um acúmulo de procedimentos-padrão necessários para 0 cumprimento de etapas burocráticas, sem que sejam devidamente levados em conta no momento do projeto, o restaurador certamente se encontrará longe de um efetivo trabalho multidisciplinar.

89 TORRACA, Giorgio. "Tecnologia del restauro delle superfici architettoniche", In: La cura dei materiali nel restauro dei monumenti. A cura di Maria Piera Sette. Roma: Bonsignori, 2001, pp. 173.

90 Segundo explica Beatriz Kühl, "O seu procedimento se caracterizava por, inicialmente, procurar entender profundamente um sistema, concebendo então um modelo ideal $e$ impondo, a seguir, sobre a obra, o esquema idealizado". Ver: KÜHL, Beatriz Mugayar. "Viollet-le-Duc e o verbete Restauração", In: VIOLLET-LE-DUC, Eugène Emmanuel. Op. cit., pp. 18. 
Ao contrário do que se pode supor, não é a obra a dizer qual o melhor caminho a seguir para sua própria conservação. $O$ conhecimento aprofundado da complexidade presente em cada edificação ou paisagem cultural em sua trajetória histórica não garante uma receita operativa única, dedutível das análises feitas. As soluções adotadas em uma restauração são sempre uma resposta de presente, culturalmente comprometida, e que depende das escolhas e caminhos estabelecidos em cada situação objetiva por cada restaurador. Essas escolhas serão tanto mais adequadas quanto maior for 0 real conhecimento da obra em sua materialidade e historicidade, porém, serão inevitavelmente uma dentre as muitas escolhas possíveis e, por isso mesmo, inteiramente de responsabilidade do autor do projeto. ${ }^{91}$ Portanto, outro ponto a ser destacado aqui é que, ainda que em posse do mesmo conjunto de levantamentos de dados sobre uma determinada edificação, as respostas aos problemas por ela apresentados serão necessariamente diferentes. Isto porque, como já se afirmou acima, não existem no campo da restauração soluções unívocas ou únicas, ao contrário, há uma multiplicidade de soluções para um determinado problema e a forma de resolvê-lo dependerá das decisões da equipe de restauradores.

Essa diversidade pode ser exemplificada de modo mais claro nas diferentes propostas apresentadas no concurso internacional de projeto de restauração do complexo monumental templo-catedral de Pozzuoli, organizado pela Região da Campanha / Itália em 2003. ${ }^{92}$

O templo-catedral de Pozzuoli é uma edificação de vicissitudes históricas complexas, que tem início com a construção de um templo por volta de 194 a.C. na acrópole da cidade, região conhecida como Rione Terra. O templo passou a ser utilizado como igreja cristã no período medieval, ainda que sem grandes modificações em sua estrutura, quando em 1632 a construção foi então encampada pela obra de ampliação da catedral, que escondeu os remanescentes do templo romano sob a decoração e estuques barrocos. Estes remanescentes vieram à luz em 1964 em consequência de um incêndio de

91 LA REGINA, Francesco. II restauro dell'architettura..., op. cit., pp. 279.

92 Os projetos apresentados pelos diversos participantes selecionados para a segunda etapa da competição, bem como a proposta vencedora - da equipe chefiada pelo arq. Marco Dezzi Bardeschi - estão disponíveis em: http://www.acmaweb.com/CONCORSOPOZZUOLl/index.htm. Acesso em: 15 dez. 2009, 16:08. Também podem ser vistos na edição especial da Rivista $A R$ - Bimestrale dell'Ordine degli Architetti di Roma e provincia, n. 60, luglio-agosto 2005. 
grandes proporções que resultou no desmoronamento de algumas paredes, no desabamento do teto e na destruição de boa parte dos revestimentos da igreja barroca. Sucedeu-se então uma obra de restauração que tinha como foco a recuperação dos restos arqueológicos, em detrimento da construção barroca, demolida em muitos pontos para dar visibilidade à construção romana. Obras de reforço estrutural utilizando ferro e concreto armado foram empreendidas paralelamente aos trabalhos de escavação arqueológica, que resultaram na descoberta de numerosos elementos decorativos de idade romana. Porém os trabalhos foram suspensos no ano de 1972, deixando a estrutura abandonada nas décadas subsequentes, sendo retomadas somente quando da organização do concurso. $\mathrm{O}$ objetivo do concurso era 0 de restituir 0 monumento à sua história e à história da cidade, tornando-o compreensível e fruível, incrementando o conhecimento a seu respeito e agindo sobre sua conformação e apresentação, tanto interna quanto externa. Isto por meio de uma atenta obra de restauração e de um acurado repensamento dos espaços, dos níveis e dos acessos. Deveria recuperar e preservar tanto o templo romano quanto sua função como catedral da cidade. Como suporte ao desenvolvimento do projeto, a comissão organizadora forneceu às equipes participantes um dossiê com todas as informações disponíveis sobre a edificação (incluindo levantamento métricoarquitetônico detalhado, estado de conservação dos materiais e análise de problemas estruturais). $O$ contato com todo esse material resultou em propostas de intervenção bastante diferentes entre si, ainda que todas estivessem, sem dúvida, compreendidas pelo campo da restauração, com respeito por todas as fases da obra e requerendo o uso de recursos criativos para a solução do complexo projeto, como exigia o edital do concurso.

Este exemplo de Pozzuoli é bastante elucidativo e ilustra com precisão a variedade de possibilidades que cada obra de restauro traz em si. Porém, apesar da diversidade de meios e mesmo da pluralidade de formulações apresentadas por cada uma das vertentes da contemporânea teoria da restauração, em qualquer um desses endereços teóricos preconiza-se um respeito absoluto pela matéria antiga, reconhecida como documento de incontestável valor histórico. Valor histórico-artístico e autenticidade material a serem tutelados de forma idônea para as gerações futuras, através de conhecimentos detalhados e de meios técnicos adequados são o fundamento do restauro e diante disto, o estudo aprofundado de seus referenciais teóricos não 
podem não figurar como um dos pilares de sustentação da prática profissional, senão à custa de perdas culturais incomensuráveis.

Independentemente da variedade cultural do patrimônio mundial, e da natureza específica presente na cultura material de cada Nação, incluindo-se aí o Brasil, o conhecimento e a aplicação de princípios sólidos de ação no campo do restauro, reconhecidos e ratificados nas convenções internacionais, a exemplo da Convenção do Patrimônio Mundial (Convention Concerning the Protection of the World Cultural and Natural Heritage - UNESCO 1972), são fundamentais para o êxito nas ações de salvaguarda e conservação dos bens culturais em qualquer contexto.

\begin{abstract}
Since the 1994 Nara Conference on Authenticity, there has been on-going debate about the applicability of restoration principles in different cultures. It is obvious that no principles should be applied without a critical recognition and assessment of the character and significance of a particular heritage. [...] each heritage needs to be based on the knowledge and understanding of its qualities and attributed values. The differences and similarities of our cultures can be discussed at length. In this discussion, we can also refer to the on-going international debate and research on new types of heritage. Each culture has its own spirituality, relationship with nature and environment, and aesthetic appreciation. ${ }^{93}$
\end{abstract}

A diversidade presente no patrimônio mundial não pode representar incoerências teórico-metodológicas nas intervenções. Julgar os valores em causa em cada caso particular baseado na cultura específica que o produziu é necessário, de outro modo, haveria um nivelamento ou homogeneização e não a desejada representatividade da riqueza cultural dos povos. Entretanto, 0 reconhecimento do valor presente nesta diversidade de bens culturais não implica em ignorar as discussões teóricas sobre a restauração, ainda que estas estejam mais concentradas em território europeu. Como afirmou Jokilehto, qualquer princípio de ação deve ser analisado criticamente e reinterpretado para a realidade local, desse modo, a metodologia de intervenção seria independente da "nacionalidade" ou da idade do monumento, ${ }^{94}$ garantindo rigor e correção na ação preservacionista.

O reconhecimento da pertinência sempre relativa de uma proposta de restauração, assim como a relativização das teorias visando sua adaptação a cada cultura específica, não podem significar um laissez faire, onde tudo é válido

${ }^{93}$ JOKILEHTO, Jukka. "Preservation Theory Unfolding", In: Future Anterior. Volume III, Number 1, Summer 2006, pp. 4.

${ }^{94}$ Idem, ibidem. 
e aceitável. ${ }^{95} \mathrm{O}$ aparato teórico oferecido pelas teorias do restauro, principalmente aquelas desenvolvidas nas últimas décadas, se reinterpretado criticamente à realidade de cada país ou cultura, traz o referencial conceitual e metodológico fundamental para as ações que visem à tutela e transmissão dos bens culturais às gerações futuras e de fato preservem os aspectos formais, históricos, memoriais e simbólicos de que esses bens são portadores.

\section{5 - restauração: projeto e uso}

Seguramente o uso de um monumento de arquitetura ou de uma área urbana é um dos meios mais eficazes para sua efetiva conservação. Edificações sem uso são freqüentemente abandonadas à própria sorte e padecem, conseqüentemente, de acelerado processo de degradação. Ao contrário, aquelas ainda em uso (seja o uso original, para o qual foi concebida, seja um novo uso compatível com suas características) recebem manutenção mais assídua e, por conseguinte, conservam-se em boas condições.

L'utilizzo infatti è un fine condizionante del restauro, perchè mette l'edificio in grado di autoproteggersi dal divenire un relitto, oggetto abbandonato e ingombrante, condizione gravida di rischi. Rappresenta anche il modo naturale per consentire, con il vivere dentro, il reciproco contatto tra persona e oggetto di architettura. Nei suoi risvolti economici, è anche un mezzo per raggiungere gli altri fini precipui del restauro, in quanto consente di mobilitare le risorse necessarie alla complessiva opera conservativa; ma pone le proprie condizioni, che il restauro deve assumere come propri fini secondari. ${ }^{96}$

Semelhante processo de degradação ocorre naquelas áreas urbanas subutilizadas, cujas funções produtivas tornaram-se obsoletas ou que foram preteridas por novas áreas de expansão. Seja em virtude da reestruturação produtiva, a qual afeta áreas industriais e portuárias, seja 0 esvaziamento populacional e desocupação dos imóveis de certas zonas nas cidades contemporâneas, assiste-se a uma deterioração do espaço público e dos imóveis que 0 constituem, acarretando ulterior queda nas condições de habitabilidade e da qualidade de vida.

Garantir um uso adequado a um monumento é certamente um dos desafios da preservação, que por isso mesmo deve ser estudado com cura, atento às características tipológicas da edificação. Este uso deve ser compatível

95 LUXEN, Jean-Louis. "Dal monumento al patrimonio: quale il significato?", In: CRISTINELLI, Giuseppe \& FORAMITTI, Vittorio (a cura di). Op. cit., pp. 31.

${ }_{96}$ DOGLIONE, Francesco. Op. cit., pp. 83. 
com as peculiaridades de cada monumento e pensado no espectro amplo de um projeto de restauro e não como pré-requisito ou fundamentação para a intervenção. Afinal, um uso incompatível pode arruinar o monumento, expondo-o a um processo de desgaste e degradação ainda mais intenso do que seu nãouso. Conforme estabelece a Carta de Veneza em seu art. 5:

A conservação dos monumentos é sempre favorecida por sua destinação a uma função útil à sociedade; tal destinação é, portanto, desejável, mas não pode nem deve alterar a disposição ou a decoração dos edifícios. $\dot{E}$ somente dentro desses limites que se devem conceber e se podem autorizar as modificações exigidas pela evolução dos usos e costumes. ${ }^{97}$

O uso, portanto, não pode ser o objetivo ou a premissa da intervenção, impondo-se sobre o objetivo primeiro do restauro que é a conservação. Diante disso, parece forçoso estabelecer aqui alguns pontos concernentes ao projeto de restauro e às suas especificidades na esfera geral da cultura arquitetônica e urbanística.

O projeto de restauração, entendido por alguns como elemento acessório no processo de conservação de edificações e sítios históricos, na realidade é etapa fundamental desta, posto ser a síntese dos conhecimentos estabelecidos com as pesquisas previamente feitas, visando prever as intervenções necessárias e controlar seus limites. Uma vez que já se estabeleceu a transformação como inerente a qualquer intervenção restauradora, bem como que tais transformações não podem ser gratuitas e injustificadas, o projeto tem como fundamento justamente circunscrevê-las dentro de um amplo quadro de maturadas reflexões, de modo a estabelecer de antemão o que deverá ser feito e de que forma será feito no curso da intervenção que se dará. ${ }^{98}$

O projeto de restauro é um tipo particular de projeto de arquitetura ou de projeto urbano, na medida em que apresenta condicionantes diversas daquelas postas para a construção do novo. Ainda assim, não representa uma coerção da liberdade criativa, sendo antes um desafio a esta. Do mesmo modo que as especificidades do terreno, o orçamento disponibilizado pelo cliente ou a

${ }^{97}$ Carta de Veneza, In: Cartas Patrimoniais, op. cit., p. 92-93.

98 Como afirma Francesco Doglione, "Al progetto di restauro affidiamo il compito di congiungere, focalizzandole in una stessa previsione di esito, la sfera delle idee e dei principi, quella delle tecniche e delle capacità operative e quella delle cognizioni sul manufatto. [...] è il risultato di una riflessione sulle diverse possibilità, la scelta di una di esse e la precisa descrizione dei modi con cui dovrà essere esseguita, degli strumenti e delle tecniche". Ver: DOGLIONE, Francesco. Op. cit., pp. 99. 
legislação são todos condicionantes do projeto de arquitetura e ainda assim não tolhem a liberdade expressiva do arquiteto, no caso da restauração, equacionar a conservação do monumento (como imagem e como documento) com um novo programa de uso ou revisar as instalações elétricas e hidráulicas, por exemplo, podem oferecer oportunidade de desenvolver a criatividade e a capacidade de projetar do restaurador. ${ }^{99}$ Todavia, ainda que seja atividade arquitetônica (ou urbanística, no caso de intervenções em sítios urbanos de valor históricocultural), que exige talento e competência no campo compositivo e criativo, o restauro de arquitetura não representa um exercício livre de criação, pois seu primeiro compromisso é com a conservação e transmissão ao futuro do bem sobre o qual deve intervir. 0 projeto de restauro, portanto,

[...] non è evidentemente una progettazione tout court, cioè una invenzione totale, libera, autonoma volta a soddisfare le esigenze inderogabili della vita moderna e dalla società dei consumi e di soddisfare le intenzionalità creative e di mutamento del progettista, ma deve essere una progettazione particolare, un processo, che discende da una indagine e verifica continua sul manufatto o artefatto da conservare. ${ }^{100}$

Dizer que o projeto de restauro não representa um projeto autônomo ou completamente livre não significa resumi-lo a uma intervenção "neutra" ou desprovida de expressão artística. ${ }^{101}$ De fato, como já apontava Renato Bonelli, a restauração é sempre ato crítico e criativo, dado que seja uma leitura crítica da realidade material e histórica da obra que se desdobra em uma proposta criativa de resolução dos problemas apresentados pela própria obra. ${ }^{102} \mathrm{O}$ que não quer dizer, deve-se reafirmar, uma operação personalista que procura impor-se à préexistência, deixando uma "marca forte" sobre esta. Trata-se, antes, de estabelecer um relacionamento de respeito frente à matéria marcada pelo tempo, procurando um verdadeiro equilíbrio de ação - nem subserviência ao passado, nem sua total subjugação pelo presente.

Outro ponto comumente levantado em relação à restauração é a impossibilidade de um verdadeiro conhecimento do objeto anterior ao início do canteiro de obras, fato que impediria a elaboração de um projeto de restauro

99 KÜHL, Beatriz Mugayar. "Restauração hoje...", op. cit., pp. 29.

100 BOSCARINO, Salvatore. Op. cit., pp. 97.

101 Sobre a negação do restauro como ato neutro, remete-se a: CARBONARA, Giovanni. Avvicinamento..., op. cit., pp. 416 e ss.

102 A definição de Bonelli é a seguinte: "Restauro come processo critico e restauro quale atto creativo sono dunque legati da un rapporto dialettico, in cui il primo definisce le condizioni che l'altro deve adottare come proprie intime premesse, e dove l'azione critica realizza la comprensione dell'opera architettonica, che l'azione creatrice è chiamata a proseguire ed integrare". Ver: BONELLI, Renato. Op. cit., pp. 347. 
detalhado. Ainda que não se possa garantir o completo conhecimento do monumento, o que impõe certo grau de "surpresa" na intervenção de restauro, isto não diminui a necessidade do projeto e não estabelece sua inoperosidade. Ao contrário, acredita-se que um projeto que nasça de um acurado ouvir 0 monumento, em suas características físicas e em sua história (que pode ser longa ou recente, mas que sempre deixa marcas sobre sua realidade material), poderá construir o fundamental elo de ligação entre o conhecimento teorizado e sua prática aplicação. Será certamente um projeto aberto, passível de sofrer modificações ao longo da obra (como de resto ocorre em qualquer obra, seja de restauro seja numa nova construção), porém sempre definido como horizonte e baliza para as ações que se desenvolverão, no absoluto respeito do monumento e com o objetivo focado na sua conservação e transmissão ao futurom 


\title{
-CAPÍTULO 2 - RESTAURAÇÃO NA FASE HERÓICA DO IPHAN
}

\begin{abstract}
Filhos de um país novo, cujo descobrimento se deu na era moderna e cuja formação política data de pouco mais de um século, os brasileiros, em geral, não se distinguem pelo culto às relíquias do passado. $O$ sentimento de respeito retrospectivo torna-se mais arraigado entre os povos de longo passado histórico. Já é tempo, entretanto, de considerarmos a beleza moral da história do Brasil, instituindo a defesa dos seus documentos. Jornal Correio da Manhã [Rio de Janeiro, 24 de janeiro de 1940]
\end{abstract}

Ações mais consistentes de restauração no Brasil têm início juntamente com o desenvolvimento da idéia de salvaguarda do acervo nacional de bens móveis e imóveis considerados portadores de valor artístico e histórico. Ainda que se tenham notícias de algumas incipientes tentativas de agir em favor da preservação de obras arquitetônicas ou de artes plásticas brasileiras desde meados do século XVIII, na realidade tais iniciativas não podem ser consideradas efetivamente restaurações ou mesmo ações sistemáticas de preservação. ${ }^{1} \mathrm{O}$ tratamento dispensado aos monumentos históricos no Brasil até o início do século XX concentrava-se em adequar as arquiteturas e estruturas urbanas herdadas de épocas passadas aos cânones estéticos vigentes e às novas noções de higiene e salubridade, seguindo o modelo das grandes reformas urbanas empreendidas em várias cidades da Europa. ${ }^{2} \mathrm{~A}$ construção e preservação da história do país era incumbência dos Institutos Históricos e dos Museus, instituições criadas ao longo do século XIX nas quais se coligiam e arquivavam documentos e objetos que narravam uma determinada história nacional. $^{3}$

O ideário preservacionista brasileiro vai ganhando corpo por volta dos anos 1920 e passa por um processo de amadurecimento e efervescentes

\footnotetext{
${ }_{1}$ Conforme se pode ver no episódio no qual o Conde das Galveias manifesta sua preocupação com a destinação de monumentos edificados pelos holandeses em Pernambuco (séc. XVIII) ou ainda quando o Ministro do Império Cons. Luiz Pedreira do Couto Ferraz reclama cuidado na reparação dos monumentos para que não se destruíssem as inscrições neles gravados (séc. XIX). Ver: Proteção e revitalização do patrimônio cultural no Brasil: uma trajetória. Brasília: SPHAN/Pró-Memória, 1980, pp. 9. Versão eletrônica disponível em: http://portal.iphan.gov.br.

2 ANDRADE, Antonio Luiz Dias de. Op. cit., pp. 106.

${ }^{3}$ RUBINO, Silvana. Op. cit., pp. 28-30.
} 
discussões ao longo de quase duas décadas, ${ }^{4}$ até se estruturar oficialmente com a criação de um serviço público visando à salvaguarda do patrimônio artístico e histórico brasileiro e ganhar um corpo jurídico para dar suporte a este órgão. Segundo Antonio Luiz Dias de Andrade:

Tais iniciativas coincidem com a emergência do ideário nacionalista, propagado por uma elite de intelectuais que, sob influência das teorias eurocêntricas do desenvolvimento das civilizações, pretenderam encontrar o caráter nacional, a essência da nação brasileira, como condição indispensável para o processo de desenvolvimento. ${ }^{5}$

Em 1936, paralelamente aos projetos de lei que eram discutidos e tramitavam na Câmara dos Deputados e no Senado brasileiros, foi instituído em caráter provisório o Serviço do Patrimônio Histórico e Artístico Nacional SPHAN, cujas atividades foram ratificadas no ano seguinte com a reorganização do Ministério da Educação e Saúde Pública e finalmente através do Decreto-lei n. 25, assinado por Getulio Vargas em 30 de novembro de $1937 .{ }^{6}$ Segundo Gustavo Capanema, chefe da pasta de Educação e Saúde, para elaboração deste projeto de lei "aproveitou-se tudo quanto de útil, entre nós, se projetara anteriormente. Foi consultada e atendida, no que pareceu conveniente, a legislação estrangeira", constituindo-se, portanto, "resultado de longo trabalho, em que foram aproveitadas as lições e os alvitres dos estudiosos da matéria".7

Mesmo trabalhando com uma estrutura provisória, o SPHAN procurou dar início a uma sistemática de inventários e estudos em vários estados do país, além de executar algumas restaurações emergenciais em bens ameaçados de

\footnotetext{
${ }^{4}$ Sobre as discussões a respeito da preservação do patrimônio ao longo dos anos 1920, ver: PINHEIRO, Maria Lucia Bressan. Neocolonial, modernismo e preservação do patrimônio no debate cultural dos anos 1920 no Brasil. São Paulo, FAU-USP, Textos para realização do Concurso de Livre-Docência, 2005, pp. 1-42.

${ }^{5}$ ANDRADE, Antonio Luiz Dias de. Op. cit., pp. 106.

${ }^{6}$ Decreto-lei n. 25, de 30 de novembro de 1937, In: Coletânea de leis sobre Preservação do Patrimônio. Rio de Janeiro: IPHAN, 2006, pp. 99-107. Ao longo de seus pouco mais de 70 anos de existência, o SPHAN sofreu diversas alterações dentro da estrutura burocrática federal, o que acarretou mudanças na figura jurídica e no nome do órgão. Em 1946 o antigo Serviço do Patrimônio Histórico e Artístico Nacional - SPHAN foi transformado em Diretoria, sob a sigla DPHAN. Em 1970 transformou-se em Instituto do Patrimônio Histórico e Artístico Nacional - IPHAN, passando a Secretaria em 1979, novamente com a sigla SPHAN. A partir de 1981, mesmo mantendo a sigla, a instituição tornou-se Subsecretaria, e, em 1990, transformou-se em Instituto Brasileiro de Patrimônio Cultural - IBPC, voltando em 1994 a denominar-se Instituto do Patrimônio Histórico e Artístico Nacional - IPHAN, sua designação atual.

7 "Exposição de motivos submetida pelo Ministro Gustavo Capanema ao Presidente Getúlio Vargas em novembro de 1937", In: Proteção e revitalização..., op. cit., pp. 72-73.
} 
ruína, principalmente na cidade de Ouro Preto, que desde 1933 havia sido elevada à categoria de Monumento Nacional. ${ }^{8}$

Os meios de que o SPHAN se valia para dar início à construção desse corpus patrimonial no Brasil, na ausência de referências locais anteriores, era certamente a experiência estrangeira sobre 0 tema, porém não simplesmente reproduzindo-a, mas adequando-a e absorvendo aquilo que nela "pareceu conveniente", tal como esclarecia o Ministro Capanema. Silvana Rubino lembra que: "Esse debate entre a busca de um caminho genuinamente brasileiro e a penetração de idéias externas é constitutivo da política oficial de proteção ao patrimônio no Brasil".9 Permeados de sentimento modernista, os preservacionistas brasileiros procuravam agir em consonância com o espírito do Manifesto Antropófago de Oswald de Andrade, devorando referenciais exógenos para em seguida degluti-los e transformá-los em autêntica cultura nacional. ${ }^{10}$ Diante desta constatação, cabe aqui um movimento retroativo, num esforço visando esclarecer melhor quais seriam então as ações erigidas como paradigmas a serem (re)interpretados e servirem de alimento a uma ação local no campo preservacionista.

O ex-chefe do então $4^{\circ}$ Distrito do SPHAN em São Paulo, Luís Saia, em artigo escrito por ocasião dos 35 anos do órgão, procura desqualificar as tentativas anteriores de sistematização da preservação de monumentos no Brasil, reputando-as "no mínimo, de válidade discutível", dado que havia "muito amor por romantismo, pouco respeito por desconhecimento". ${ }^{11}$ Ainda segundo 0 arquiteto, a organização do SPHAN, com os técnicos e estudiosos que desde 0 primeiro momento a ele se vincularam, "representou, entretanto, uma recolocação mais realista e mais culta do problema, conduzido pelo que havia de mais apto e atual em matéria de arquitetura e artes plásticas." ${ }^{12}$

No entanto, ainda que se tenha erigido uma história oficial do SPHAN na qual lhe é outorgado um caráter inaugural - quase mítico,$-^{13}$ na verdade as

\footnotetext{
${ }^{8}$ Decreto n. 22.928, de 12 de julho de 1933.

${ }^{9}$ RUBINO, Silvana. Op. cit., pp. 46.

10 A esse respeito ver artigo: CAVALCANTI, Lauro. "O Quarteto Antropofágico: da redescoberta ao moderno e ao contemporâneo", In: CHAGAS, Mário (org.). Revista do Patrimônio Histórico e Artístico Nacional - Museus: antropofagia da memória e do patrimônio. Instituto do Patrimônio Histórico e Artístico Nacional, n. 31, 2005, pp. 62.

${ }_{11}$ SAIA, Luís. "Até os 35 anos, a Fase Heróica", In: CJ Arquitetura, n. 14, 1977, pp. 17.

12 Idem, ibidem.

${ }^{13}$ Silvana Rubino lembra que: "O PHAN, desde sua fundação e em suas diversas fases sempre contou e recontou seu mito de origem" (RUBINO, Silvana. Op. cit., pp. 46).
} 
ações do Patrimônio Nacional não se deram em "terra virgem", visto que, como esclarece 0 próprio Ministro Capanema, foram aproveitadas as lições dos estudiosos da matéria. ${ }^{14}$ Voltando-se, então, aos projetos de lei que, embora descartados, serviram de base à redação do Decreto-lei n. 25 que instituiu 0 SPHAN em 1937, ${ }^{15}$ pode-se inferir algumas das referências adotadas para a construção de uma idéia de patrimônio e, conseqüentemente, de preservação em solo nacional.

No projeto redigido por Jair Lins em 1925 são feitas menções às bulas papais e às leis de preservação de diversos países, tais como a Áustria, Suécia e Noruega, Itália, Egito, Turquia, Portugal, França, México, etc, demonstrando conhecimento do que se praticava à época na Europa e fora dela e alertando para o fato de que "A proteção especial do patrimônio artístico dos Estados, por parte dos Poderes Públicos, não é uma novidade que se vai ensaiar, constituindo, pelo contrário, um passo muito tardo que vai ser dado pela legislação federal brasileira". ${ }^{16}$ Corroborando, dessa forma, a idéia de que a preservação em solo brasileiro não seria uma invenção ou inovação, e sim uma resposta local ao desejo humano (e portanto universal) de preservação da arte e da cultura com vistas à sua transmissão para as gerações futuras.

Nesse mesmo espírito, o projeto do deputado Wanderley Pinho, de 1930, além de aprimorar alguns tópicos do projeto de Jair Lins, "continha disposições mais eficazes para resguardar a visibilidade e o destaque dos monumentos; tornava administrativo o processo de catalogação compulsória e instituía o Conselho Deliberativo e Consultivo do órgão."17 Ao afirmar no artigo 14 de seu projeto de lei que

A construção, reconstrução, modificação e destruição de imóveis e a alteração de jardins e terrenos na vizinhança de algum imóvel catalogado

\footnotetext{
14 "Exposição de motivos...", op. cit., pp. 72.

15 Segundo Antonio Luiz Dias de Andrade: "O projeto de lei elaborado por Jair Lins a partir da legislação de outros países, tidas especialmente as leis francesa e italiana, embora desconsiderado pela Câmara, adquire uma importância capital. De seus preceitos originar-se-á a proposta apresentada em 1930 pelo deputado Wanderley Pinho, bem como constituirá a base do Decreto-lei $n^{\circ} 25$ de 30 de novembro de 1937, até hoje em vigor" (ANDRADE, Antonio Luiz Dias de. Op. cit., pp. 108).

16 "Esboço de anteprojeto de lei federal elaborado pelo jurista Jair Lins na qualidade de relator da Comissão designada em julho de 1925 pelo Presidente Mello Vianna, do Estado de Minas Gerais, para organizar a proteção do patrimônio histórico e artístico", In: Proteção e revitalização..., op. cit., pp. 35. Grifo nosso.

${ }_{17}$ ANDRADE, Antonio Luiz Dias de. Op. cit., pp. 108.
} 
depende do assentimento da Inspetoria de Defesa do Patrimônio Histórico-Artístico Nacional, ou das repartições congêneres estaduais. ${ }^{18}$

Isto é, manifestando uma preocupação com a ambiência dos bens imóveis, o deputado Wanderley Pinho mostrava-se afinado com as mais atualizadas discussões feitas no campo da restauração naquele momento, as quais seriam, no ano seguinte, compiladas e confirmadas na Carta de Restauração de Atenas, primeiro documento internacional sobre preservação de monumentos históricos. Nela encontra-se a recomendação para adoção de cuidados especiais com as proximidades dos monumentos, para que se garanta a preservação de "algumas perspectivas particularmente pitorescas", e no trato das massas vegetais "convenientes a determinados conjuntos de monumentos para Ihes conservar o caráter antigo". ${ }^{19}$ Ainda que o foco permaneça no monumento isolado, que o entorno deve privilegiar e destacar, certamente é possível perceber aqui um movimento de transformação do conceito de monumento, que vai tendendo à inclusão de novos programas.

Quando o Brasil dá início à sua corrida preservacionista, a despeito de ser considerado por Jair Lins um "passo muito tardo", levando-se em conta que as leis das diversas Nações por ele elencadas haviam sido sem exceção promulgadas durante o século XIX, nas décadas de 1920-30 a restauração era ainda um campo de conhecimento bastante recente e em processo de paulatina consolidação teórico-metodológica.

Como já se acenou no capítulo anterior, se a apropriação de edificações de épocas passadas é prática comum em diferentes culturas desde remotos tempos, pelo menos até o século XV mesmo nas ações de caráter mais propriamente conservativo não se pode falar de restauração tal como se compreende nos dias atuais, dada a ausência de um distanciamento histórico na apreciação e apropriação desta herança.

Il restauro in senso moderno nasce con la rivalutazione ottocentesca della storia, con l'acquisizione della coscienza dell'idea del passato come altro dal presente, del carattere singolare ed irripetibile di ogni evento e di ogni esperienza, unita alla fiducia nella ricostruibilità della storia, nella possibilità di reperire negli avvenimenti una logica intrinseca, una

18 "Projeto do Deputado José Wanderley de Araújo Pinho", In: Proteção e revitalização..., op. cit., pp. 48.

${ }_{19}$ Carta de Atenas (1931), In: Cartas Patrimoniais, op. cit., pp. 14. 
razionalità che ne spieghi la successione, quasi sempre in una visione progressiva. $^{20}$

De fato, é a partir de finais do século XVIII, notadamente em ambiente europeu, que a preservação deixará de responder a razões de uso, adquirindo lentamente um cunho cultural, culminando então com a formação de uma disciplina específica encarregada de tal tarefa - a restauração. Esta, que passa a integrar-se às ciências, desenvolve diferentes meios de intervir sobre os monumentos do passado, num processo de amadurecimento, no qual o respeito ao patrimônio - entendido como documento de história e de arte - vai tomando corpo passo-a-passo. Com o reconhecimento do caráter insubstituível e único dos monumentos históricos, passa-se de uma profunda liberdade em sua utilização e tratamento, para formas mais "disciplinadas" de conservação e restauração. $^{21}$

Sembra, in ogni modo, che sia possibile riconoscere, a partir da una serie di confusi e difformi atteggiamento verso le preesistenze, un lento processo d'avvicinamento al moderno e più rigoroso concetto di restauro, anche se la parola è antica e risale alla lingua latina, ove ricopriva un campo semantico diverso e per certi aspetti più generico, valendo inoltre come sinonimo di ricostruzione, da un lato, e di rigenerazione, anche morale e politica dall'altro. ${ }^{22}$

Ao longo do século XIX, se já havia um aparente consenso na obrigação moral de salvaguardar os monumentos de arte e de história com intuito de transmiti-los em herança às gerações futuras, todavia, as formas de garantir essa preservação estavam longe de qualquer concordância. Ao contrário, diferentes e até mesmo antitéticas posturas em relação à preservação são acaloradamente debatidas e também postas em prática em diferentes países europeus; Viollet-le-Duc (1814-1879) e John Ruskin (1819-1900) polarizam os debates a partir da segunda metade dos oitocentos..$^{23}$ Suas idéias encontram adeptos e críticos fervorosos em diversas partes da Europa, tais como na Itália e Alemanha, além da própria França e Inglaterra, onde foram concebidas. ${ }^{24}$

Apesar das controvérsias que até hoje cercam o nome de Viollet-leDuc, ${ }^{25}$ não se pode dirimir a importância que este arquiteto autodidata tem no

20 BELLINI, Amadeo. "Teorie del restauro e conservazione architettonica", In: Tecniche della conservazione. Milano: Franco Angeli, 1986, pp. 14.

${ }^{21} \mathrm{CHOAY}$, Françoise. Op. cit., pp. 40.

22 CARBONARA, Giovanni. Avvicinamento..., op. cit., pp. 50.

${ }^{23}$ Para estudo das idéias de Viollet-le-Duc e John Ruskin, ver principalmente: VIOLLETLE-DUC, Eugène Emmanuel. Op. cit.; RUSKIN, John. Op. cit.

${ }^{24}$ CARBONARA, Giovanni. Avvicinamento..., op. cit., pp. 133 e ss.

25 KÜHL, Beatriz Mugayar. "Viollet-le-Duc...”, op. cit., pp. 22-23. 
campo da restauração de monumentos. Identificado por muitos, exclusivamente, como "pai do restauro estilístico", a análise de sua obra - seja a teórica, seja a prática - está longe de poder ser resumida a tal colocação. Os estudos recentes de sua obra alertam para as contradições e incoerências presentes em seus escritos e na relação dialética que se estabelece entre os princípios teóricometodológicos por ele instituídos e sua experiência operativa nos canteiros de restauração. ${ }^{26}$ Ainda assim, não se pode ignorar o fato de que as intervenções de Viollet-le-Duc, ao longo de sua extensa carreira como restaurador, caminham a passos largos na direção das maciças reintegrações (Fig. 1/2 e 3), tendendo

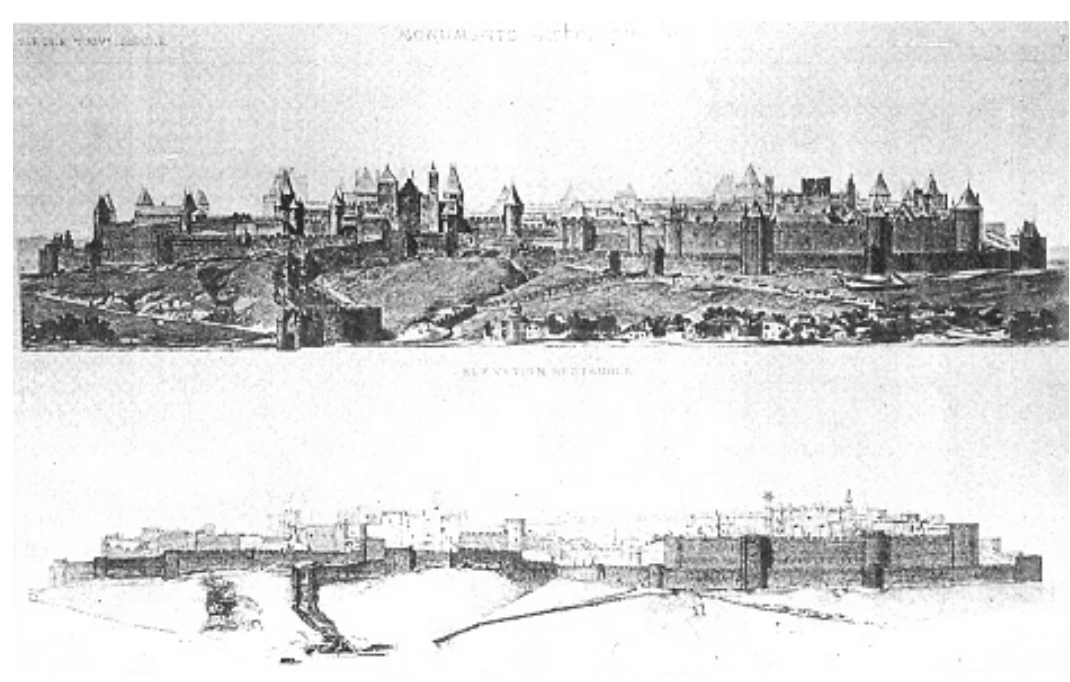

Fig. 1/2 - Carcassonne, levantamento e proposta de reconstituição de Viollet-le-Duc. Fonte: CARBONARA, 1997, pp. 109. ao abandono das posturas mais comedidas do início de sua trajetória. ${ }^{27}$

Para Viollet-leDuc, cada monumento, ainda que considerado como testemunho de uma época, não era pensado em sua individualidade, e sim como representante de um determinado estilo (em grande medida idealizado), ao qual deveria se adaptar.

Toda obra a ser restaurada, deveria ser analisada e estudada de modo pormenorizado antes de qualquer intervenção. Esse conhecimento aprofundado sobre o monumento daria então ao arquiteto-restaurador instrumentos para compreender a concepção original do projeto, e daí, a autoridade para intervir. A análise precisa e rigorosa, como nos estudos científicos, daria ao restaurador respostas unívocas e inquestionáveis, não apenas sobre qual o estado real da obra, mas a respeito da intenção do construtor primitivo, dessa maneira acreditava ele - ao restaurador caberia apenas revelar o "estado completo que pode não ter existido nunca em um dado momento". ${ }^{28}$

${ }^{26}$ VASSALLO, Eugenio. "Eugène Emmanuel Viollet-le-Duc", In: CASIELLO, Stella (a cura di). La cultura..., op. cit., pp. 70-75.

${ }^{27}$ Giovanni Carbonara, citado em VASSALLO, Eugenio. Op. cit., pp. 75.

28 VIOLLET-LE-DUC, Eugène Emmanuel. Op. cit., pp. 29. 
Esta postura racionalista e, num certo sentido, bastante pragmática de Viollet-le-Duc é radicalmente oposta àquela adotada pelo pensador inglês John Ruskin.

Para Ruskin a arquitetura é por excelência um instrumento de recordação, que atesta às múltiplas gerações 0 trabalho daqueles que a precederam:

Fazendo-nos ver e tocar o que viram e tocaram as gerações desaparecidas, a mais humilde habitação possui, da mesma forma que 0 mais glorioso edifício, o poder de nos pôr em comunicação, quase em contato, com elas. ${ }^{29}$

Desse modo, toda arquitetura deve ser transmitida ao futuro de maneira

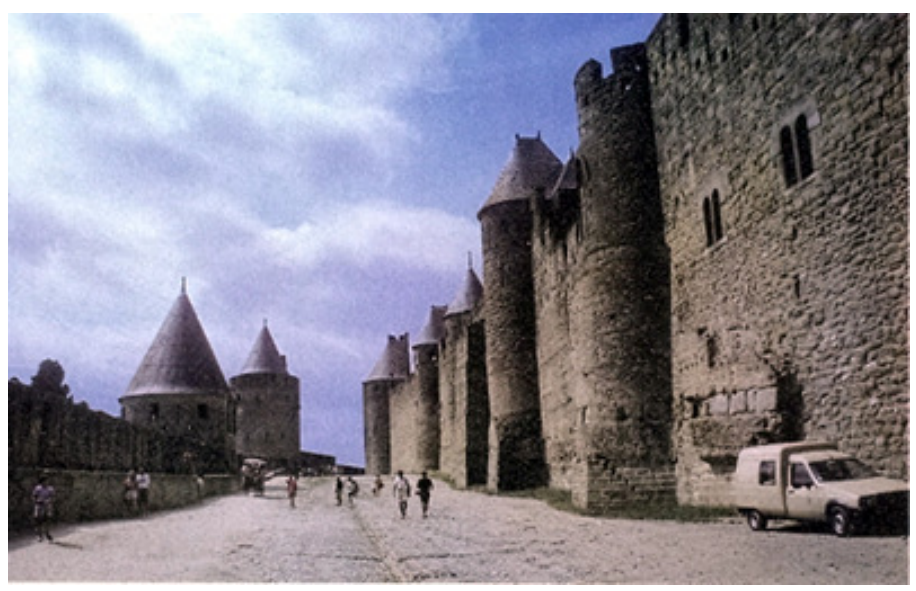

Fig. 3 - Carcassonne, estado atual após a reconstrução executada no século XIX. Fonte: CARBONARA, 1997, pp. 133. autêntica e verdadeira, para que a mensagem da qual é portadora seja comunicada corretamente; daí descende a definição negativa que Ruskin faz da restauração - ela representa a mais completa destruição que um edifício pode sofrer, ${ }^{30}$ pois retira do monumento as marcas deixadas pela passagem do tempo e acrescenta novas superfícies, sem 0 valor da obra original:

O primeiro passo para a restauração [...] é despedaçar a obra antiga; 0 segundo, usualmente, é erguer a imitação mais ordinária e vulgar que possa escapar à detecção, mas em todos os casos, por mais cuidadosa, e por mais elaborada que seja, é sempre uma imitação, um modelo frio daquelas partes que podem ser modeladas, com adições conjeturais. ${ }^{31}$

As antigas edificações são tanto daqueles que as construíram no passado quanto das gerações futuras, portanto, em que pese sua condenação às ações restauradoras, Ruskin defende a conservação da arquitetura do passado como obrigação moral e sua manutenção como meio de evitar a restauração. ${ }^{32}$ Para Ruskin e os adeptos do Anti-Restoration Moviment, o restauro como praticado até então era sinônimo de destruição e falsificação, entretanto, sua militância pela não-restauração não pode ser entendida como

${ }^{29}$ CHOAY, Françoise. Op. cit., pp. 140.

30 RUSKIN, John. Op. cit., pp. 79.

31 Idem, pp. 80.

32 Idem, pp. 82. 
sinônimo de abandono dos monumentos históricos à própria sorte. Ao contrário, como já foi visto anteriormente, é uma condenação do restauro tal como amplamente praticado naquele momento e a conseqüente defesa da conservação e manutenção constantes das obras do passado como uma
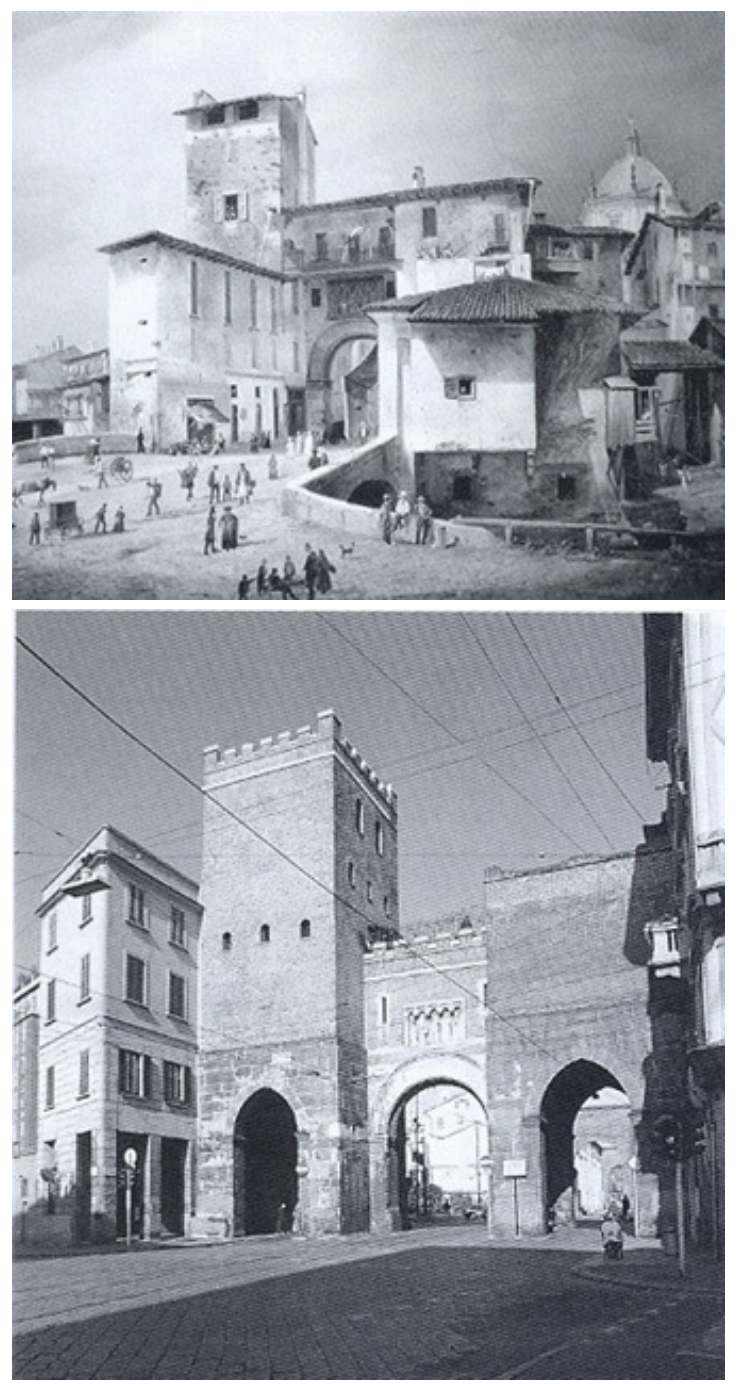

Fig. 4/5 - Porta Ticinese, Milão. Estado antes do restauro e após a intervenção de Boito (1861-65). Fonte: MARCONI, 2003, pp. 130-131. alternativa possível e mais correta, que evitaria a descaracterização e a falsificação de tal herança.

Na passagem do século XIX para o XX, os princípios teórico-metodológicos do restauro são reelaborados pelo italiano Camillo Boito (1836-1914) a partir das várias vertentes existentes. Boito está no centro de uma efervescência de novas idéias, onde a restauração, a despeito de já firmada como disciplina, é um saber novo e "apesar de o tempo ser breve, até mesmo os critérios sobre o restaurar se transformaram, principalmente nesses últimos anos", dessa maneira, afirma ainda, "Nem eu, [...] sinto-me livre de alguma contradição". ${ }^{3}$ A contradição aludida pelo autor se dá entre suas maturadas elaborações teóricas no campo da restauração, resumidas na Conferência apresentada na Exposição de Turim em junho de $1884,{ }^{34}$ e as intervenções restauradoras de que fora encarregado em sua juventude, nas quais procura a valorização do monumento a partir da recuperação dos elementos caracterizadores da "forma primeira" do edifício, numa clara aproximação com os princípios violletianos (Fig. 4/5). ${ }^{35}$

$\mathrm{Na}$ referida Conferência, Camillo Boito apresenta as propostas de Viollet-le-Duc e de John Ruskin como pares opostos, ambas vias perigosas para garantia da salvaguarda dos monumentos:

[...] le istanze "estremiste" delfanti-restoration movement hanno seminato dubbi e inquietudine nel suo pensiero, e spinto la teoria di Viollet come a un estremo opposto: il pericolo del falso e il rischio dell'abbandono alla

${ }^{33}$ BOITO, Camillo. Os Restauradores..., op. cit., pp. 57.

${ }^{34}$ Idem, pp. 60.

${ }^{35}$ DI BIASE, Carolina. Op. cit., pp. 175. 
rovina continueranno a fronteggiarsi nei suoi scritti, e a reclamare una alternativa ragionevole. ${ }^{36}$

Esta "alternativa razoável" se constituiria numa nova maneira de tratar os monumentos históricos que lentamente começaria a se configurar: mais ponderada e mais informada, dado os avanços da arqueologia e da história da arte. ${ }^{37}$ Com ela, 0 aspecto documental dos monumentos ganha preponderância sobre seus aspectos formais, assim, além da mínima intervenção, da distingüibilidade e reversibilidade das intervenções, ${ }^{38}$ deveria haver um acompanhamento do processo de restauro através de documentação precisa, com os levantamentos das reais condições da obra antes, durante e depois da intervenção, somados às justificativas das ações executadas. Toda restauração deveria ser respeitosa em relação aos vários estratos temporais que compunham o monumento, garantindo, desse modo, a fidedignidade do documento histórico.

Apesar de tender mais aos aspectos conservativos - dada sua consideração dos monumentos como documentos históricos que deveriam ser transmitidos ao futuro em sua integridade -, Boito conclui que a restauração é um mal necessário, nos casos em que a "doença" exija procedimentos "cirúrgicos" mais radicais. A figura do arquiteto, comparável à do cirurgião, ${ }^{39}$ era identificada como responsável por agir em favor da preservação dos monumentos a partir de metodologias operativas, não podendo omitir-se ou abster-se de intervir. Se por um lado, condena a "velha escola" de Viollet-le-Duc, que produzia a falsificação do antigo através do engenho, fazendo vencer a mentira insidiosa, por outro lado, alertava para a "lógica impiedosa" de deixar o monumento morrer ao invés de lançar mão de todos os meios disponíveis para salvá-lo. ${ }^{40}$

Le tappe della cultura italiana del restauro, nellintervallo storico fra Boito e Giovannoni, si presentano discontinue e contraddittorie, per la varietà compositiva con cui, nel pensiero e nella pratica dei suoi attori, compare, di volta in volta, l'interesse per le fonti storiche, per l'accuratezza dei controlli filologici, per la prodenza del metodo archeologico. Per un Luca Beltrami che "ricostruisce" la torre del Castello di Milano, affidando la riproduzione di un "documento" smarrito alla certezza di minuziose ricerche, c'è un Giacomo Boni che, dopo le sperienze di restauro del Palazzo ducale e del campanile di S. Marco, e soprattutto a causa di

\footnotetext{
36 Idem, pp. 166.

37 CHOAY, Françoise. Op. cit., pp. 164.

38 Princípios já estabelecidos desde 0 início do século XIX, principalmente em relação ao restauro arqueológico. A esse respeito ver: KÜHL, Beatriz Mugayar. "Notas sobre...", op. cit., pp. 183-185.

39 DI BIASE, Carolina. Op. cit., pp. 167-168.

40 BOITO, Camillo. Os Restauradores..., pp. 57.
} 
quelle sperienze, riscopre la chiarezza scientifica dell'archeologia e vi si dedica totalmente, abbandonando le incertezze disciplinare del restauro architettonico; per un Rubbiani che affida alla conoscenza del dato storico la legittimità di "integrazioni" e "abbellimenti", in una sorta di rilettura in chiave estetica delle "arditezze" di Viollet, c'è un D'Andrade che muove dalla conoscenza dei reperti per produrre, in forma simulata, il "documento" archeologico del Borgo. ${ }^{41}$

Já no período entre-guerras, ainda em ambiente italiano, a figura mais proeminente no campo da restauração é Gustavo Giovannoni (1873-1947), responsável pela retomada das propostas de Camillo Boito, que, segundo Beatriz Kühl, "[...] levaram muito tempo para se afirmar e difundir". ${ }^{42}$ Retomando a leitura dual proposta por Boito, Giovannoni constrói uma narrativa na qual reforça o enquadramento das teorias de Viollet-le-Duc e de John Ruskin em pólos opostos, da extrema intervenção ao deixar o monumento exposto à ação do tempo, colocando-se, então, numa posição "intermediária" em meio a essas linhas de força. ${ }^{43}$

Com grande ascendência em sua época, a corrente defendida por Giovannoni é conhecida como restauro científico ou filológico, e preconiza o máximo esforço no sentido da conservação e consolidação, evitando quanto possível a efetiva restauração da obra, entendida como um mal necessário, concordemente com os princípios boitianos. A restauração propriamente dita deveria limitar-se à mínima intervenção, sem que se retirasse qualquer adição que à obra tenha sido imposta. Em casos onde houvesse necessidade de completamentos para garantir a estabilidade da edificação, estes deveriam ter um caráter necessariamente diverso do antigo, com adoção de materiais diferenciados e formas simplificadas, para chegar, segundo Giovannoni, a um elemento quase neutro, que não estivesse nem em harmonia nem em contraste com a configuração original. ${ }^{44}$ Todo processo de intervenção deveria ser acompanhado de documentação precisa, com os levantamentos das reais condições da obra no momento da intervenção e as justificativas das ações executadas, além de desenhos e fotografias. A valorização do aspecto documental dos monumentos históricos é ressaltada em relação aos aspectos formais.

${ }^{41}$ TORSELLO, Paolo. Restauro architettonico..., op. cit., pp. 96.

${ }^{42}$ KÜHL, Beatriz Mugayar. "Notas sobre...", op. cit., pp. 198.

${ }^{43}$ GIOVANNONI, Gustavo. "Voce Restauro...", op. cit., pp. 128.

${ }^{44}$ Idem, pp. 128. 
Giovannoni participou ativamente nas discussões que redundaram na redação não apenas da Carta de Restauração de Atenas (1931), como também da Carta Italiana de Restauro, de 1932. As técnicas de conservação apresentadas na Carta de Restauração de Atenas ${ }^{45}$ reforçadas pelas diretrizes colocadas por Giovannoni, ${ }^{46}$ diferenciam os procedimentos segundo a tipologia e a idade do edifício, reiterando, entretanto, a idéia de que cada caso é um caso particular e, por isso, merece uma solução específica. Assim, para a restauração dos monumentos da Antiguidade, recomenda-se apenas a anastilose ou 0 restauro de recomposição, e para edificações de outros períodos, após minucioso estudo das condições da obra e dos problemas que tenha, definir qual encaminhamento seguir, sempre respeitando a matéria original, aplicando 0 princípio da distingüibilidade e da mínima intervenção. Ademais, como já se disse anteriormente, essa nova teoria demonstrava a preocupação não apenas com o monumento isolado, mas com seu entorno, que deveria também ser alvo de intervenções no sentido de valorizar o monumento, garantindo sua visibilidade e fruição.

Tal era o "estado da arte" na área de preservação de monumentos e, ao que parece, este universo era (ainda que parcialmente ou com alguma distorção) de conhecimento daqueles que tinham 0 intento de configurar uma política nacional de proteção. Sabe-se que as leis européias sobre o tema, principalmente a francesa e a italiana, foram utilizadas como modelo para nossa legislação. Além disso, segundo Cecília Rodrigues dos Santos, "A Carta de Atenas de restauro, sobre conservação dos monumentos de arte e de história, será a principal referência para o IPHAN que começava a se organizar e iniciava suas atividades" ${ }^{47}$ Confirmando esta informação, em entrevista concedida ao Diário da Noite, o primeiro diretor do SPHAN, Rodrigo Melo Franco de Andrade, afirmava:

Recentemente se reuniu em Atenas uma conferência internacional para assentar, na órbita mundial, as mesmas e oportunas medidas que 0 nosso Serviço objetiva e sob o alto e inspirado sentido de que os

${ }^{45}$ Carta de Atenas (1931), In: Cartas Patrimoniais. op. cit., pp. 15-16.

${ }^{46}$ GIOVANNONI, Gustavo. "Voce Restauro...", op. cit., pp. 128.

47 SANTOS, Cecília Helena Godoy Rodrigues dos. Mapeando os lugares do esquecimento: idéias e práticas na origem da preservação do patrimônio no Brasil. São Paulo, FAU-USP, Tese de Doutorado, 2007, pp. 64. 
patrimônios históricos e artísticos nacionais transcendem e são de interesse da comunidade universal. ${ }^{48}$

Resta saber como tais pressupostos foram (re)interpretados no Brasil e de que modo refletiram nas práticas de inventário, tombamento e restauração empreendidas a partir dos anos 1930 pelo Serviço do Patrimônio Histórico e Artístico Nacional.

Sobre os critérios de seleção para inclusão de bens num dos quatro Livros de $\mathrm{Tombo}^{49}$ da instituição já foram produzidos diversos trabalhos acadêmicos e alguns deles, inclusive, publicados. ${ }^{50} \mathrm{~A}$ listagem dos bens tombados é a face mais visível da atuação do Patrimônio Nacional, hoje em dia pode-se encontrá-la até mesmo na internet, oferecendo material rico e abundante para os pesquisadores. Outra faceta de bastante visibilidade do órgão de preservação federal, já desde os tempos de sua fundação, é a Revista do Patrimônio, publicação oficial do IPHAN cujo primeiro número saiu já em 1937, tendo se estendido até os anos 1969. Após alguns anos de interrupção nas edições, ela volta a ser publicada a partir de 1984, estando atualmente em seu

48 ANDRADE, Rodrigo M. F. de. "A defesa do patrimônio histórico e artístico dos brasileiros", In: Rodrigo e o SPHAN. Coletânea de textos sobre patrimônio cultural. Rio de Janeiro: Fundação Nacional Pró-memória, 1987, pp. 24.

49 O Decreto-lei n. 25 estabelece quatro Livros do Tombo: Arqueológico, Etnográfico e Paisagístico; Histórico; das Belas-Artes; das Artes Aplicadas. Neles seriam inscritos os bens considerados de excepcional valor para cada uma das categorias. A respeito do rito de consagração que representa a inclusão de um bem em um dos Livros de Tombo institucional, cabe remeter ao trabalho de Silvana Rubino, no qual se destaca a não homogeneidade existente entre o número de bens inscritos em cada uma das quatro categorias, sendo que, de 1937 a 1967, nenhum bem foi inscrito no Livro das Artes Aplicadas e apenas 3,7\% do total de bens o foram no Livro Arqueológico, Etnográfico e Paisagístico, sendo portanto, "A grande distinção inscrita pela prática do SPHAN foi entre história e arte, entendida como arte erudita. [...] As categorias preservadas remetem, seja em história ou arte a uma noção semelhante, de acabamento e conclusão. A obra bem acabada, resolvida formalmente, e o episódio que chegou a termo". (RUBINO, Silvana. Op. cit., pp. 123-124.). No início do século XX, porém, o historiador da arte vienense Alois Riegl já alertava para a inutilidade de se separar monumentos artísticos e monumentos históricos, posto não existir, na concepção do autor, um valor artístico absoluto, mas apenas um valor relativo, tendo em vista a crença na inexistência de um ideal artístico objetivo e absoluto que, a partir do início do século XX, paulatinamente se impôs à antiga tese de que havia um tal cânone. Em decorrência, para Riegl não existem monumentos artísticos, apenas históricos, pois seu valor não é um valor para a arte e sim para a história da arte. A esse respeito ver: CUNHA, Claudia dos Reis e. "Alois Riegl e o 'Culto Moderno dos Monumentos", In: Revista CPC, São Paulo, v. 1, n. 2, maio/out. 2006, pp. 6-16.

50 Dentre esses trabalhos deve-se destacar: ANDRADE, Antonio Luiz Dias de. Op. cit.; FONSECA, Maria Cecília Londres. Op. cit.; RUBINO, Silvana. Op. cit.; MILET, Vera. A teimosia das pedras. Um estudo sobre a preservação ambiental no Brasil. Olinda: Prefeitura de Olinda, 1988; SANT'ANNA, Márcia. Da cidade-monumento à cidadedocumento. A Trajetória da Norma de Preservação de Áreas Urbanas no Brasil (19371990). Salvador, FAU-UFBa, Dissertação de Mestrado, 1995; SANT'ANNA, Márcia. A cidade-atração..., op. cit.; SANTOS, Mariza Veloso Motta. Op. cit.. 
trigésimo terceiro número. Conforme se pode ver no site oficial do IPHAN, a Revista do Patrimônio:

Durante muitos anos dedicou-se à publicação de artigos e ensaios sobre o patrimônio nacional, arte e história, com a colaboração de muitos especialistas de dentro ou de fora do Instituto, como Rodrigo Melo Franco de Andrade, Lucio Costa, Mário de Andrade, Gilberto Freire, Joaquim Cardoso, Curt Nimuendaju e muitos outros. A orientação reinante nesses números era a da colaboração especializada sobre temas estéticos, históricos, antropológicos e sociológicos. Os números traziam um leque temático aberto, com o predomínio do ângulo teórico e técnico sobre as questões diversificadas. ${ }^{51}$

Um aspecto menos visivel dos trabalhos de preservação do IPHAN ao longo de suas sete décadas de atuação são as obras de restauração, seja porque tais obras não figuram entre os trabalhos divulgados pela própria instituição, ${ }^{52}$ seja porque 0 acesso a essa documentação, tais como cadernos de obras, inventários, pareceres, etc., é menos franqueado para os pesquisadores da ação institucional do IPHAN. Não obstante, aos poucos os pesquisadores vão entrando em contato com estas fontes e produzem novos trabalhos, focados nas restaurações empreendidas ou supervisionadas pelo órgão federal de preservação em diversos monumentos do país. ${ }^{53}$

A leitura de algumas publicações do próprio IPHAN, tais como os Documentos de Trabalho de Lucio Costa $^{54}$ ou a correspondência entre Mario de Andrade e Rodrigo M. F. de Andrade, ${ }^{55}$ fornecem elementos para compreensão de algumas das características do momento fundador do Patrimônio Nacional e dos encaminhamentos da instituição ao longo dos anos em que Rodrigo esteve à frente da direção do órgão (1937-1967), período conhecido como "fase

$51 \quad$ Disponível em: $<$ http://portal.iphan.gov.br/portal/montarPaginaSecao.do?id=13226\&sigla=Institucional\&re torno=paginalnstitucional>. Acesso em 14 maio 2008, 12:44.

$52 \mathrm{Na}$ verdade, não se trata de uma omissão na divulgação das obras de restauração. Desde 0 início estas ações eram anunciadas, entretanto, tal divulgação era (e permanece sendo) endereçada a um público leigo, omitindo-se, portanto, dados técnicos e escolhas teórico-metodológicas, que importariam aos pesquisadores.

53 Deve-se aqui fazer menção aos seguintes trabalhos: D’ASSUMPÇÃO, Livia Romanelli. Preservação urbana em Diamantina. Aspectos teóricos e a prática institucional (19381970). Salvador, FAU-UFBa, Dissertação de Mestrado, 1995; GONÇALVES, Cristiane Souza. Op. cit.; MAYUMI, Lia. Monumento e autenticidade..., op. cit.; MAYUMI, Lia. Taipa, canela..., op. cit.

54 COSTA, Lucio. Documentos de Trabalho. Organizado por José Pessôa. Rio de Janeiro: IPHAN, 1999.

55 ANDRADE, Mário. Mário de Andrade: cartas de trabalho. Correspondência com Rodrigo Melo Franco de Andrade, 1936-1945. Brasília: Fundação Nacional Pró-memória, 1981; ANDRADE, Rodrigo M. F. de. Op. cit. 
heróica" ${ }^{56}$ Cotejando essas leituras com as observações realizadas pelos diversos pesquisadores que se debruçaram sobre o tema a partir de diversos enfoques, revelam-se as contradições das ações implementadas, bem como 0 particular modo de interpretar e adequar conceitos "estrangeiros" à realidade local.

Em relação à seleção de bens a serem inscritos nos Livros de Tombo nos primeiros anos de ação institucional, a pesquisa de Silvana Rubino aponta para a construção de um "mapa do Brasil" consoante com os anseios daqueles estados que haviam tomado a dianteira na defesa de seus patrimônios:

Como veremos no conjunto do que se tombou, as iniciativas estaduais e as definições construídas nessa proto-história nortearam a política nacional: foi onde havia uma tradição de se guardar tradições que 0 SPHAN realizou seu trabalho mais acabado. [...] Cristalizou-se, através do tombamento, muito do que já estava prefigurado em toda a discussão anterior à criação do Serviço, desenhando assim um mapa do país já existente há muito para as tradições de lideranca local de estados como Bahia, Minas Gerais, Pernambuco e São Paulo.

No universo de bens culturais a serem tombados, os monumentos arquitetônicos prevaleceram e a arte popular, embora contemplada em artigos e estudos, ficou relegada à segundo plano, prevalecendo a arte erudita, especialmente a religiosa, posto que

$\mathrm{Na}$ prática dos tombamentos, porém, a prioridade foi dada aos remanescentes da arte colonial brasileira, justificada pelos agentes institucionais como decorrência do processo de urbanização, que já se acelerava, e do saque e comercialização indevidos de bens móveis, que eram vendidos por antiquários brasileiros a colecionadores, sobretudo estrangeiros. $^{58}$

A leitura da história e do passado era feita pelos "modernistas da Repartição"59 a partir da noção de civilização material, da qual os objetos e as arquiteturas remanescentes eram testemunhas. Portanto, foram privilegiados aqueles locais onde se deram os grandes ciclos econômicos, nos quais havia abundância de traços materiais, sendo a presença portuguesa no processo de ocupação do território (por ser a mais antiga) o principal foco sobre o qual

${ }^{56}$ Designação dada por Luís Saia. Ver: SAIA, Luís. Op. cit., pp. 17.

${ }^{57}$ RUBINO, Silvana. Op. cit., pp. 61.

${ }^{58}$ FONSECA, Maria Cecília Londres. Op. cit., pp. 107.

${ }^{59}$ Expressão de Lauro Cavalcanti. Ver: CAVALCANTI, Lauro (org). Modernistas na repartição. Rio de Janeiro: UFRJ / IPHAN, 1993. 
recaíram as atenções do SPHAN num primeiro momento. ${ }^{60}$ Segundo Mariza Veloso dos Santos:

A Academia SPHAN nasce ancorada numa idéia básica que é o registro da nação, cuja face era preciso tornar visível; não através da incorporação de traços da natureza, como no romantismo, mas através da identificação de uma tradição cultural que tivesse uma duração no tempo, cujo passado era preciso alcançar, e que tivesse uma visibilidade no espaço, cuja configuração e moldura era preciso estabelecer.61

Critério semelhante àquele que regia a seleção dos bens a serem tombados - 0 estabelecimento da "brasilidade" ou da "tradição brasileira" -
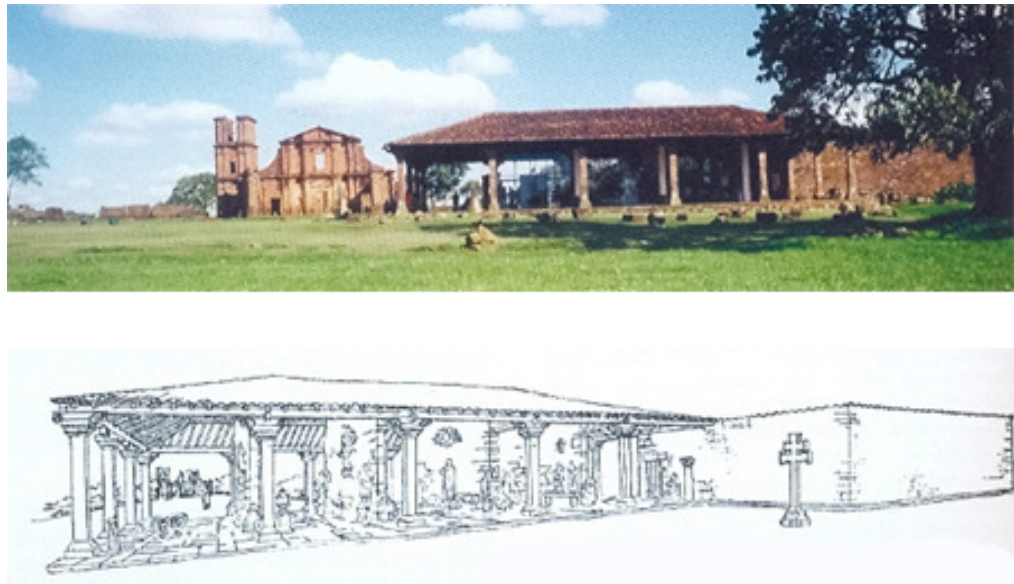

Fig. 6/7 - Ruínas de São Miguel das Missões, consolidação da Igreja e construção de museu, seguindo projeto de Lucio Costa.

Fonte: MORI et alli, 2006, pp. 126.

parece guiar as intervenções nos bens já tombados, seja nas obras sob encargo direto dos funcionários do SPHAN, seja naquelas por eles supervisionadas. Antonio Luiz Dias de Andrade aponta para a dificuldade de se estabelecer um método de atuação no tocante às intervenções nas edificações já tombadas nesta fase que pode ser chamada de empírica, dada a inexistência de experiências anteriores no país. ${ }^{62}$ Ainda assim, como já foi apontado acima, se faltavam experiências locais para referenciar os trabalhos de conservação e restauro, as práticas européias eram conhecidas no círculo de técnicos ligados à instituição e poderiam, tal como foi feito em relação à legislação, servir de base para o desenvolvimento de uma práxis brasileira.

No relato de sua primeira "missão" como diretor da Divisão de Estudos e Tombamentos do SPHAN, onde permaneceu de 1937 a 1972, o arquiteto Lucio Costa apresenta um dos grandes dilemas da restauração: reconstruir ou apenas consolidar ruínas? Na viagem de inspeção aos remanescentes das Reduções Jesuíticas no sul do país (Fig. 6/7), Lucio Costa se depara com vestígios da ocupação jesuíta esparramados por um vasto território, conhecido como Sete

${ }^{60}$ FONSECA, Maria Cecília Londres. Op. cit., pp. 107.

61 SANTOS, Mariza Veloso Motta. "Nasce a Academia SPHAN", In: Revista do Patrimônio - Cidadania. Rio de Janeiro: IPHAN, 1996, n. 24, pp. 78.

62 ANDRADE, Antonio Luiz Dias de. Op. cit., pp. 119 e ss. 
Povos das Missões. ${ }^{63}$ Ainda que as recomendações fornecidas pela Carta de Atenas indiquem para ruínas a possibilidade de anastilose, isto é, recomposição do monumento com os vestígios encontrados, ${ }^{64}$ Lucio Costa afirma: "Com efeito, não se pode pensar em reconstruir São Miguel ou mesmo recompor qualquer de suas partes; os trabalhos deverão limitar-se, tão somente, a consolidar e conservar". ${ }^{\prime 5}$ Mais adiante, o arquiteto recomenda prudência no trato com estrutura já tão fragilizada, advertindo: "Tratando-se de trabalho por sua própria natureza difícil e traiçoeiro, todas as precauções deverão ser tomadas, ainda quando aparentemente desnecessárias, a fim de prevenir qualquer eventualidade de acidente ou desmoronamento" ${ }^{\prime 66}$ Entretanto, quando 0 assunto é a construção da casa do zelador e do Museu para abrigar em São Miguel os remanescentes das outras Reduções (construções novas), a sugestão do arquiteto revela um enfoque diverso: deveriam ser utilizados os materiais antigos, "aproveitando-se o material das próprias ruínas" para a estrutura e, para a cobertura, "telha antiga ou fabricada de acordo, não se devendo empregar as modernas telhas de canal cujo tamanho e aspecto destoariam do resto". ${ }^{67}$ Parece contraditório que os restos de materiais encontrados não devessem ser utilizados para a anastilose das ruínas, mas pudesse servir de suprimento às novas edificações.

Um outro episódio demonstra conhecimento e concordância com as proposições da Carta de Atenas: é a preocupação de Lucio Costa com o intento da prefeitura do Rio de Janeiro de construir "uma cortina de prédios de apartamentos" na vizinhança da Igreja Nossa Senhora do Outeiro da Glória. ${ }^{68}$ Em seu parecer, o arquiteto já se colocava contra a prevalência dos interesses privados sobre os públicos, defendendo a qualidade do espaço urbano, "pois não se trata tanto, no caso, de beneficiar a igreja, como, principalmente, a 'paisagem urbana', num de seus trechos mais característicos e impregnados de tradição", 99 isto é, não apenas o monumento isolado, mas sua ambiência deveria ser resguardada.

63 O relatório da visita aos Setes Povos das Missões encontra em: COSTA, Lucio. Op. cit., pp. 21-42.

${ }^{64}$ Carta de Atenas (1931), In: Cartas Patrimoniais. op. cit., pp. 16.

${ }_{65}$ COSTA, Lucio. Op. cit., pp. 25-26.

66 Idem, pp. 38-39.

67 Idem, pp. 39.

68 Idem, pp. 47-52.

69 Idem, pp. 50. 
Em outros casos, Lucio Costa, assim como os chefes das regionais do IPHAN, não são tão cautelosos na proposta de intervenção, recomendando e executando a remoção de acréscimos posteriores à fatura da edificação, como exemplifica o Edifício da Alfândega em Salvador, no qual "será de toda conveniência, à vista da necessidade de obras [...] aproveitar a oportunidade $e$ recuar a referida caixilharia para a prumada das colunas internas, restabelecendo-se assim o aspecto original".70

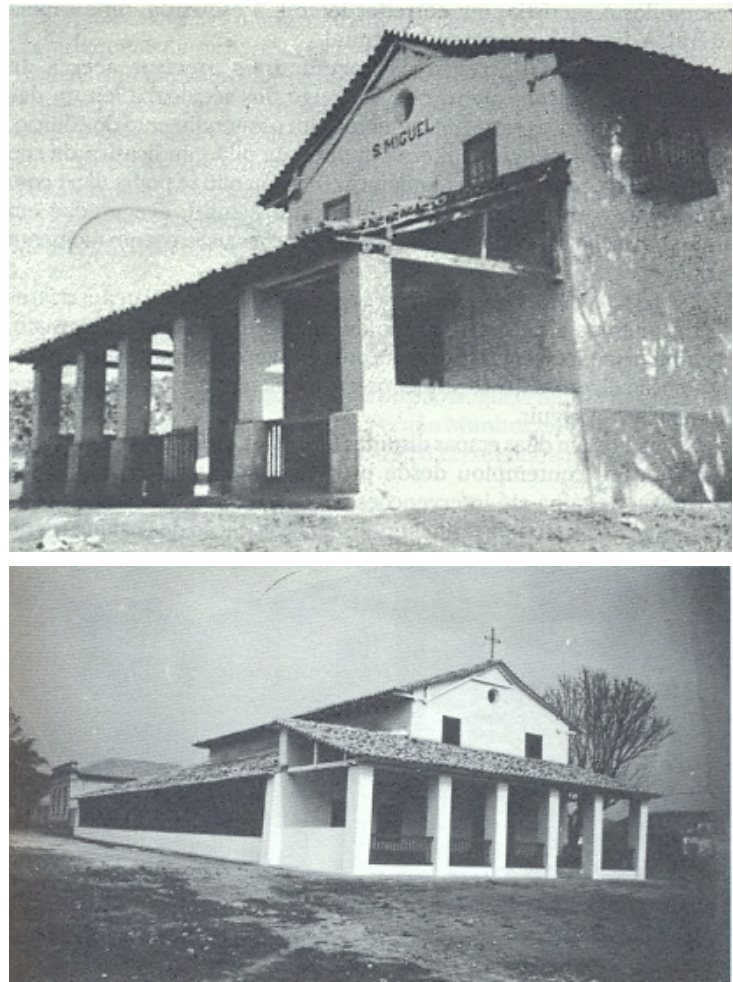

Fig. 8/9 - Igreja de São Miguel Paulista, antes e após a restauração. Fonte: GONÇALVES, 2007, pp. 70 e 101.
Esta recomposição de elementos "originais" à custa da supressão de adições posteriores, tendo em vista a unidade e coerência estilística do monumento, era uma prática bastante comum entre os técnicos do Patrimônio, ainda que esta postura contrariasse as disposições da teoria da restauração. A Carta de Atenas chamava a atenção para uma tendência ao abandono de reconstituições integrais em favor do respeito e conservação de todas as estratificações da obra, visando à autenticidade do documento histórico e a salvaguarda de sua historicidade. ${ }^{71}$

Em sua dissertação de mestrado, Cristiane Gonçalves analisa quatro intervenções de restauração realizadas pela regional paulista do SPHAN entre os anos 1937 e $1975 .{ }^{72}$ Este trabalho revela que a busca pela unidade de estilo foi praticamente constante neste período e, em alguns casos, foi levada a extremos que transfiguraram completamente o monumento que se desejava preservar.

O primeiro dos quatro casos estudados por Cristiane Gonçalves, restauração da Igreja de São Miguel Paulista (Fig. 8/9), juntamente com as obras na Igreja de Nossa Senhora do Rosário de Embu, ${ }^{73}$ configura-se como

\footnotetext{
70 Idem, pp. 78.

${ }^{71}$ Carta de Atenas (1931), In: Cartas Patrimoniais. op. cit., pp. 13.

72 GONÇALVES, Cristiane Souza. Metodologia para a Restauração Arquitetônica. A experiência do Serviço do Patrimônio Histórico e Artístico Nacional em São Paulo, 19371975. São Paulo, FAU/USP, Dissertação de Mestrado, 2004. Neste trabalho será feita referência à publicação originada da dissertação: GONÇALVES, Cristiane Souza. Op. Cit.

${ }^{73}$ Experiência relatada por Antonio Luiz Dias de Andrade: ANDRADE, Antonio Luiz Dias de. Op. cit., pp. 122-127.
} 
estabelecedor do modelo a ser seguido em todas as restaurações seguintes, ao inaugurar os "procedimentos de trabalho, as soluções técnicas e o perfil conceitual que nortearia as futuras intervenções" ${ }^{74} \mathrm{Em}$ ambas as situações, 0 avançado estado de arruinamento das edificações reclamava por intervenções emergenciais, o que, somado ao fato de estarem estas restaurações entre as primeiras promovidas pelo SPHAN, talvez justifique a ausência de um projeto de restauro mais detalhado e a aplicação de soluções contraditórias, que ora aceitam as adições posteriores, ora as destroem visando à recomposição de uma presumida situação original.

Em relação ao desejo de recomposição da estrutura "original", o exemplo da intervenção na antiga Casa de Câmara e Cadeia de Atibaia é talvez 0 mais ilustrativo. ${ }^{75} \mathrm{~A}$ ameaça de demolição mobiliza a população local, que reivindica a recuperação desta edificação cuja forte presença urbana suplanta seu aspecto em nada monumental. Desejosos de instalar ali um museu municipal, uma comissão local solicita a vistoria dos técnicos do Patrimônio, os quais até o momento nenhum tipo de interesse haviam demonstrado em relação a este edifício. No entanto, após a vistoria, o chefe da regional paulista do IPHAN, Luís Saia, declara a possibilidade de recuperação e o interesse no tombamento da antiga Casa de Câmara Cadeia. Inscrita no livro de tombo histórico do Patrimônio Nacional, em 1955, segundo parecer de Edgard Jacintho, além de seu valor de exemplar típico das casas de câmara e cadeia da primeira metade do século XIX, destacava-se a "integridade nas linhas principais do partido" e o "bom estado de conservação no exterior", ${ }^{76}$ o que justificaria seu tombamento como monumento nacional. Tal leitura da obra diverge da posição adotada por Luís Saia, para o qual a aparência assumida pela edificação era na realidade fruto de uma descaracterização após sucessivas reformas pelas quais teria passado. Em sua análise, Saia não a classifica dentro da tipologia casas de câmara e cadeia, como o faz Jacintho, mas em relação a um outro modelo: 0 da arquitetura tradicional (entenda-se colonial) paulista. Isto o leva a uma completa transfiguração do monumento através da restauração por ele conduzida, pois:

[...] ao invés das prospecções arquitetônicas guiarem as formulações de restauro, Luís Saia, ao contrário, direciona as investigações prospectivas a partir do fio condutor de suas proposições, previamente elaboradas,

74 GONÇALVES, Cristiane Souza. Op. cit., pp. 65. Esta mesma idéia aparece em: MAYUMI, Lia. Taipa, canela preta..., op. cit., pp. 66.

75 Idem, pp. 135-158.

76 Idem, pp. 137. 
RESTAURAÇÃO: diálogos entre teoria e prática no brasil nas experiências do iphan 2_restauração na fase heróica do iphan

alterando, assim, a seqüência lógica da metodologia própria ao restauro de edificações. ${ }^{77}$

Contraditoriamente, apesar de o tombamento ter se dado em nome do valor histórico da edificação, a restauração - em grande medida dada a "inversão metodológica" de Saia - anulou essa historicidade, inventando um
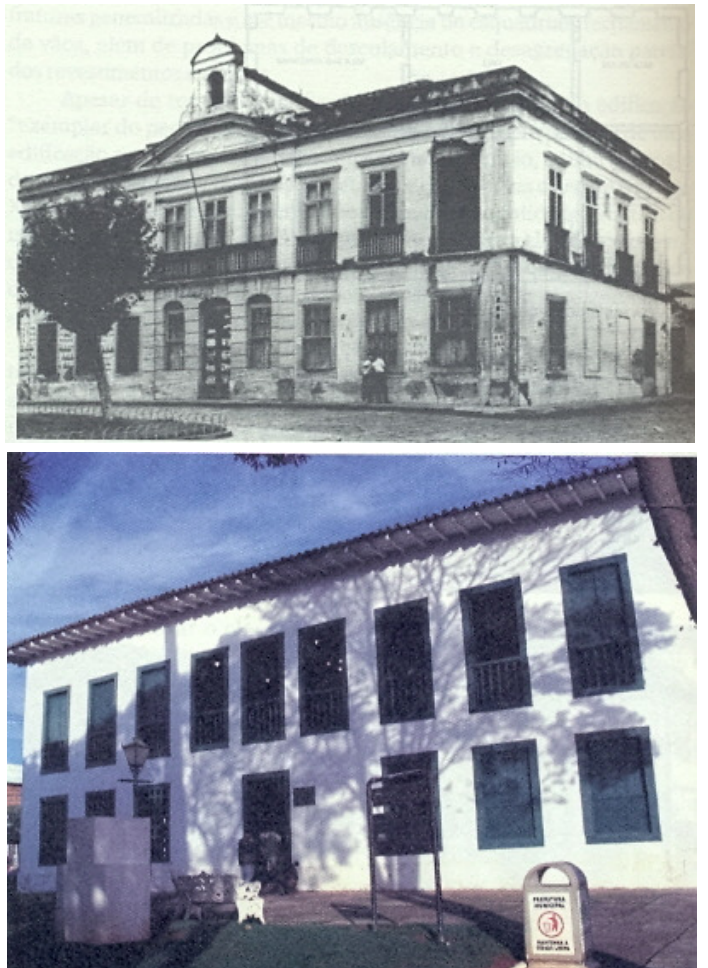

Fig. 10/11 - Antiga Casa de Câmara e Cadeia de Atibaia, antes e após as obras de restauro. Fonte: GONÇALVES, 2007, pp. 142 e 158.

monumento que nunca existiu. Ou, como conclui Antonio Luiz Dias de Andrade:

Confrontadas as informações obtidas na documentação aos argumentos utilizados na defesa das soluções oferecidas para a reconstituição da forma que se desejava original, verificamos o quanto se distanciou da realidade histórica em favor de uma interpretação decorrente de uma idéia. A idéia da arquitetura tradicional paulista, a qual cumpria fazer preponderar entre todos os edifícios escolhidos como testemunhos. ${ }^{78}$

Assim, percebe-se que:

A modalidade técnica escolhida para o trabalho de restauração enquadra-se nessa [...] lógica de embelezamento do estilo e conseqüente diluição das marcas sociais. Apesar das afirmações em contrário, a tradição preservacionista no Brasil nunca conseguiu superar a orientação doutrinária consagrada por Viollet-leDuc, defensor da chamada "reintegração estilística" que não é outra coisa senão o delírio de "purificar" o prédio em vias de restauração de quaisquer acréscimos posteriores à construção original. ${ }^{79}$

O exemplo da restauração na antiga Casa de Câmara e Cadeia de Atibaia (Fig. 10/11) é certamente um caso limite, no qual o desejo de expurgar da edificação todas as marcas de um passado recente e, por isso, indesejável, é conduzido pelo dirigente da regional paulista do SPHAN até às últimas conseqüências, ${ }^{80}$ acarretando um certo mal-estar entre a direção central,

\footnotetext{
77 Idem, pp. 145.

${ }^{78}$ ANDRADE, Antonio Luiz Dias de. Op. cit., pp. 153.

79 MICELI, Sergio. "SPAHN: refrigério da cultura oficial" In: Revista do Patrimônio Histórico e Artístico Nacional. Rio de Janeiro: SPHAN/Pró-Memória, n. 22, 1987, pp. 4445.

80 O procedimento de Luís Saia pode ser entendido através da construção historiográfica por ele operada sobre as casas bandeiristas. Em seu texto "Quadro Geral dos Monumentos Paulistas", Saia afirmava que "Dos dois caminhos disponíveis para intentar esta pesquisa [sobre os monumentos paulistas], preferimos estabelecer, como hipótese de trabalho, uma procura das teses que caracterizam a formação paulista, para o que procuramos determinar os sucessivos períodos da colonização na sua expressão regional" (SAIA, Luís. "Quadro geral dos monumentos paulistas", In: Morada Paulista. São Paulo: Ed. Perspectiva, 1978, pp. 25.). Procura, portanto, estabelecer um modelo de análise que fosse válido para o caso paulista e, ao construir esse modelo, não deixa
} 
no Rio de Janeiro, e a chefia de São Paulo. ${ }^{81}$ Ainda assim, em outros exemplos de "reintegração estilística" não parece haver muitas dissensões entre os auxiliares técnicos e a direção central, como atesta outro caso: a Igreja de São Cosme e Damião, no município de Igaraçu/PE. ${ }^{82}$

Em relação à preservação de sítios

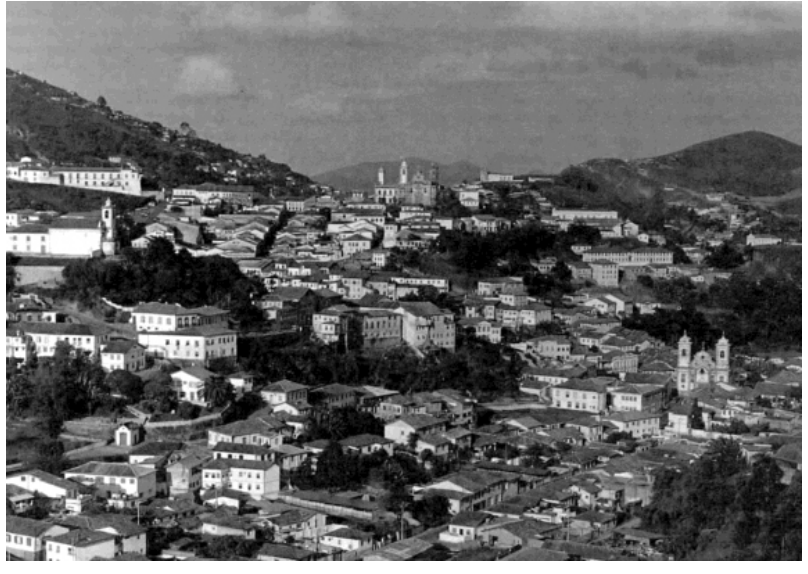

Fig. 12 - Ouro Preto, vista geral da expansão urbana, 1985. Fonte: Revista do Patrimônio, n. 22, pp. 121. urbanos, de que o SPHAN é pioneiro, os critérios de intervenção não são muito distintos daqueles adotados para os monumentos isolados ou pequenos conjuntos edificados: manutenção das características "originais", seja através de "limpezas" em edificações corrompidas por transformações recentes, seja através da construção de novas construções em harmonia com o entorno, conforme recomendavam os técnicos (Fig. 12). Esta peculiar forma de intervir ficou conhecida entre os moradores dos núcleos tombados como "estilo patrimônio". ${ }^{83}$

A adoção de critérios que à primeira vista parecem tão distintos não parece ser fruto de incoerência, mas da certeza a respeito de qual passado os técnicos do Patrimônio Nacional desejavam deixar em herança às gerações futuras. $^{84}$ No lastro das idéias elaboradas para legitimar uma determinada

espaço para as especificidades de cada sítio visitado, que deve se encaixar nesse quadro geral pré-estabelecido nas obras de restauro.

${ }^{81}$ ANDRADE, Antonio Luiz Dias de. Op. cit., pp. 144-147.

${ }^{82} \mathrm{~A}$ Igreja de São Cosme e Damião, localizada em Igaraçu/PE, passou por um extenso período de obras de restauro, que se estendeu de 1942 a 1958. Nesse longo processo, "progressivamente foi se afirmando a intenção de restituir as formas perdidas. [...] As singelas modificações realizadas a princípio foram sugerindo novas alterações e, como uma bola de neve, tornou-se irreversível a reconstituição do suposto frontispício do século XVI, sob inspiração do quadro de Franz Post, exigindo o sacrifício da obra do século XVIII", conforme narra Antonio Luiz Dias de Andrade (Idem, pp. 129).

83 Ver: MOTTA, Lia. "A Sphan em Ouro Preto: uma história de conceitos e critérios". In: Revista do Patrimônio Histórico e Artístico Nacional. Rio de Janeiro: SPHAN / PróMemória, n. 22, 1987, pp. 112-113. E também: D’ASSUMPÇÃO, Livia Romanelli. Op. cit., pp. 149-196.

${ }^{84}$ No prefácio aos Documentos de Trabalho de Lucio Costa, José Pessôa afirma que: "sua análise do acervo a ser protegido está intimamente ligada a sua idéia de qualidade artística, que faz com que a construção humana, popular ou erudita, possa ser denominada arquitetura, sendo portanto o que convém preservar para as gerações futuras. É a vontade da arte, a vontade da beleza, a vontade de forma, ou nas suas palavras, a intenção plástica, que caracteriza tanto os antigos monumentos como a construção da moderna arquitetura brasileira" (COSTA, Lucio. Op. cit., pp. 19. Grifo nosso). 
concepção de conceitos-chave, tais como história, passado e memória, funcionários e colaboradores do SPHAN desenvolveram uma forma de atuação que privilegiou lugares, datas e fatos, aos quais foi dada visibilidade por meio dos bens tombados e, por oposição, tornaram obscurecidos outros registros, através de bens excluídos da lista dos monumentos nacionais. Na escolha dos
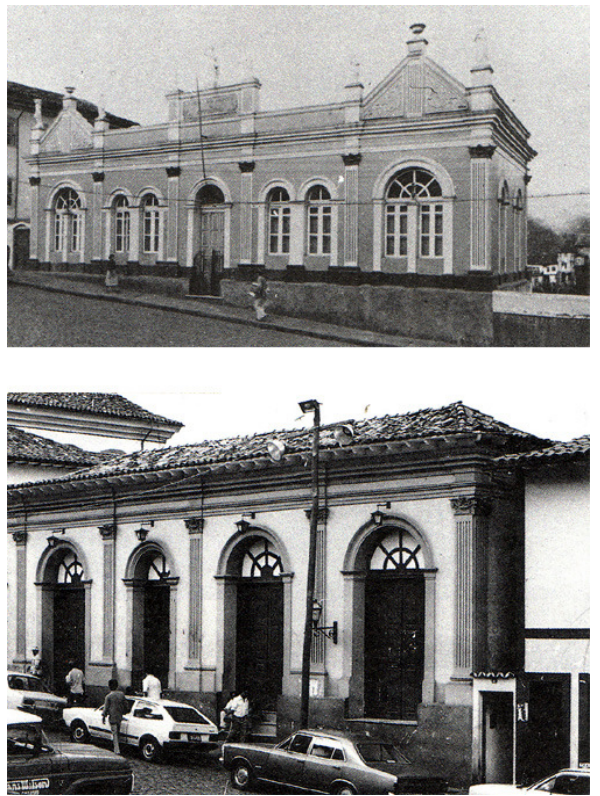

Fig. 13/14 - Ouro Preto, Liceu de Artes e Ofícios, transformado em Cine Vila Rica, projeto de Lucio Costa. Fonte: Revista do Patrimônio, n. 22, pp. 111.

bens a serem inscritos nos livros de tombo da instituição, bem como na maior parte das intervenções empreendidas pelo SPHAN durante a fase heróica, prevaleceu a busca pela pureza estilística (Fig. 13/14), requerendo dos monumentos a proximidade com os modelos previamente determinados a partir das teses que caracterizavam a formação e desenvolvimento da arquitetura brasileira, ${ }^{85}$ não deixando espaço para as especificidades de cada sítio visitado, os quais deveriam se encaixar nesse quadro geral préestabelecido. A valorização dos bens encontrados se dava, então, na exata medida em que se aproximassem ou se afastassem do "tipo" idealizado. ${ }^{86}$

$\mathrm{Na}$ ausência de critérios ou princípios de ação claramente estabelecidos ou de discussões a respeito da restauração e seus desenvolvimentos como campo disciplinar, a atuação do órgão era fortemente embasada da figura de Lucio Costa, cujos pareceres e indicações quase sempre prevaleciam (mesmo após sua aposentadoria). De resto, não se encontram maiores referências a um debate conceitual e das teorias da restauração nas práticas preservacionistas implementadas no Brasil neste momento. Conforme destaca Márcia Sant'Anna:

85 Deve-se destacar que tais teses foram sendo constituídas paralelamente ao corpus patrimonial brasileiro e pelos mesmos agentes. As viagens de levantamento e pesquisa informavam a nascente história da arquitetura brasileira, assim como essa história fornecia os dados para legitimar as escolhas feitas. A esse respeito, ver: RODRIGUES, Marly. Op. cit., pp. 26 e ss., especialmente pp. 29. Também sobre a relação entre a história da arquitetura brasileira e a preservação, remete-se ao seguinte artigo: PINHEIRO, Maria Lucia Bressan. "A História da Arquitetura Brasileira e a Preservação do Patrimônio Cultural", In: Revista CPC. São Paulo, v.1, n.1, nov. 2005/ abr. 2006, pp. 4174.

${ }^{86}$ A construção desse "tipo" idealizado se aproxima das propostas de Viollet-le-Duc, que acreditava na possibilidade de um conhecimento total sobre a história e que essa relação com a história permaneceria imutável ao longo do tempo - ou seja, o que é válido hoje, o será também para no futuro, não deixando margens para dúvidas ou inquietudes na aplicação desse conhecimento nas intervenções de restauro. 
Os modernistas do patrimônio não se filiavam abertamente a nenhuma corrente européia de restauro, e as discussões teóricas em torno do assunto não pareciam fazer parte do seu cotidiano nem despertar grandes questões. A firme convicção de que o seu pensamento estético conduzia à verdade artística, os colocava à salvo de hesitações e ambigüidades nas suas decisões. [...] A restauração, portanto, não se configurava como um momento de solução entre tensões históricas e artísticas mas somente como possibilidade científica de restituição a um determinado estado. 87

Dessa forma, e munidos de suas convicções a respeito de qual passado a instituição tinha como obrigação salvaguardar, os agentes do SPHAN constituíram ao longo das três primeiras décadas de atuação um corpus patrimonial bastante homogêneo, ainda que nem sempre tão congruente, tendo em vista certas "concessões" feitas àqueles imóveis de interesse apenas regional porém ameaçados de demolição, ${ }^{88}$ ou então às curiosidades artísticas ou históricas, ${ }^{89}$ que também foram tombadas.

Muito mais do que à Carta de Atenas de 1931, os preservacionistas que se agregaram ao redor do SPHAN eram tributários da outra Carta de Atenas, aquela de 1933, fruto do quarto Congresso Internacional de Arquitetura Moderna - CIAM, redigida por Le Corbusier. ${ }^{90}$ As intervenções nos monumentos históricos são vistas, desse modo, não como um problema de restauração, a ser resolvida dentro deste campo de conhecimento, mas como problema de arquitetura. Luís Saia afirma:

Uma das tarefas centrais da arquitetura moderna - e talvez do próprio homem moderno - é encontrar os termos de convivência positiva do passado com as pretensões e falsos valores impostos à dignidade humana pelas experiências negativas desse mesmo passado. [...] Os 35 anos de experiência do IPHAN contaram com a participação de arquitetos brasileiros que não possuíam nenhuma formação especializada em restauração, mas cujo conhecimento da arquitetura, permanentemente atualizados pelo estudo do tradicional e do

${ }^{87}$ SANT'ANNA, Márcia. Da cidade-monumento..., op. cit., pp. 144. Esta volta ao estado (hipoteticamente) originário coadunava-se com a máxima do restaurador francês Violletle-Duc, que em meados do século XIX definia que "restaurar um edifício não é mantê-lo, repará-lo ou refazê-lo, é restabelecê-lo em um estado completo que pode não ter existido nunca em um dado momento" (VIOLLET-LE-DUC, Eugène Emmanuel. Op. cit., pp. 29).

${ }^{88}$ Como no caso da Igreja Matriz de Nossa Senhora do Rosário, em Lavras/MG. Ver: COSTA, Lucio. Op. cit., pp. 64.

${ }^{89}$ Por exemplo, o Convento da Sagrada Família em Salvador/BA ou o Teatro Pedro II em Sabará/MG. Ver: Idem, pp. 83 e 136.

$90 \mathrm{~A}$ Assembléia do IV CIAM, que deu origem à Carta de Atenas, ocorreu num cruzeiro entre Marselha e Atenas em novembro de 1933. A Carta de Atenas foi divulgada somente em 1941 e inicialmente sem autoria, somente alguns anos depois sua autoria foi assumida por Le Corbusier. Ver: LE CORBUSIER. A Carta de Atenas. Tradução e introdução de Rebeca Scherer. São Paulo: Hucitec / Edusp, 1993. A referência neste trabalho será sempre à edição que consta na coletânea Cartas Patrimoniais: Carta de Atenas (1933), In: Cartas Patrimoniais. op. cit., pp. 21-90. 
contemporâneo, conduziu este trabalho a um nível de profundo respeito pelos documentos do passado e de inegável atualidade na sua formulação cultural. Não houve apenas coincidência de arquitetos de vanguarda estarem na condução dos problemas de proteção do nosso acervo tradicional. Ao contrário, este fato permitiu que o IPHAN encontrasse uma orientação correta $[\ldots . .]^{91}$

Orientação claramente dada pela Carta de Atenas do CIAM: "Nem tudo que é passado tem, por definição, direito è perenidade".92, somente aqueles bens que se apresentavam como herança positiva deveriam, para os modernistas do Patrimônio, ser perpetuados na memória da cidade e de seus cidadãos. 0 critério de separação entre as influências positivas e negativas do passado era dado pelo viés da arquitetura, com dívida irrefutável aos princípios do funcionalismo: "procurando atribuir explicações lógicas e racionais aos fenômenos arquitetônicos, compartilhando suas opções teóricas e ideológicas com o exercício profissional junto ao SPHAN, não dissociando o processo de restauro da prática do projeto". ${ }^{33}$

Uma última observação que parece necessária com relação à norma de intervenção em monumentos: no Brasil inexiste uma legislação específica sobre o tema. ${ }^{94}$ O Decreto-lei n. 25 , que permanece válido até hoje, explicita quais bens podem ser enquadrados como monumentos nacionais e como proceder para tombá-los, entretanto, cala em relação aos procedimentos que podem ou devem ser adotados para sua efetiva preservação. As leis que vieram depois têm caráter complementar, especificando sobre a preservação de ruínas arqueológicas e pré-históricas, do patrimônio subaquático ou, mais recentemente, do patrimônio imaterial, permanecendo a ausência de orientação sobre o venha a ser restauro e quais os métodos e técnicas aceitáveis neste campo.

$\mathrm{Na}$ verdade, criou-se uma espécie de "jurisprudência" através do acúmulo de experiências práticas no campo, que, num processo de retroalimentação, parece dar conta das orientações sobre qual o melhor caminho a se percorrer em cada caso específico, dispensando-se, assim, uma definição mais acabada. Porém, todo processo está calcado no empirismo e as decisões dependem dos técnicos envolvidos, não havendo efetivamente um padrão, o que resulta em ações às vezes incoerentes ou pouco claras com relação aos critérios

${ }^{91}$ SAIA, Luís. "Até os 35 anos...", op. cit., pp. 16.

${ }_{92}$ Carta de Atenas (1933), In: Cartas Patrimoniais. op. cit., pp. 52.

${ }^{93}$ ANDRADE, Antonio Luiz Dias de. Op. cit., pp. 154.

94 Ver: Coletânea de leis..., op. cit. 
adotados dentro de uma mesma Superintendência Regional ou entre essas e a direção central. Os questionamentos surgidos ao longo dos anos 1960 e 1970 em relação à forma de atuação do SPHAN na chamada "fase heróica" parecem indicar que a fé nessa "jurisprudência" não é de todo indiscutívelø 


\title{
- CAPÍTULO 3 - RESTAURAÇÃO NA FASE MODERNA DO IPHAN
}

\author{
A preservação de um conjunto histórico não se esgota, \\ simplesmente, no seu reconhecimento e no compromisso de \\ garantir sua permanência no decorrer da história, enquanto \\ espaço de viver coletivo. É, a um só tempo, a conservação e \\ a valorização dos elementos que o compõem como as ruas e \\ becos, as igrejas e praças, as casas e, acima de tudo, a \\ preservação do homem com seu viver e suas práticas. \\ Vera Bosi [Núcleos históricos: recuperação e revitalização, 1986]
}

No capítulo anterior viu-se que técnicos e dirigentes do Serviço do Patrimônio Histórico e Artístico Nacional tinham conhecimento das leis e das teorias relativas à preservação de monumentos vigentes à época, especialmente a Carta de Atenas de Restauração (1931). Igualmente viu-se que tais teorias eram aplicadas de forma não-ortodoxa, com inúmeras concessões, feitas principalmente em função de uma rejeição à arquitetura produzida em passado recente, que feria o senso estético dos preservacionistas brasileiros, comprometidos com os princípios da arquitetura funcionalista e, portanto, muito mais tributários da Carta de Atenas do CIAM (1933) e seus conteúdos do que da área do restauro. As soluções adotadas tanto em relação aos critérios para seleção de bens a serem tombados, quanto ao partido e método utilizados nas restaurações emanavam do campo da arquitetura e eram resolvidos como problema de arquitetura, desconsiderando-se a especificidade da restauração como campo disciplinar autônomo. ${ }^{1}$

Segundo Silvana Rubino:

Nesse processo seletivo, o SPHAN construiu um "mesmo" em oposição a um "outro" [...] O SPHAN elegeu um Brasil antepassado que exclui alguns atores contemporâneos ao delimitar claramente de quem "descendemos". Não é um discurso da superioridade branca, lusitana e cristã conferido pela detração do outro e sim pela sua exclusão, por meio da construção de um elo de ligação com o passado que remete a bisavós, antepassados e ancestrais dignificados. O melhor do passado do SPHAN não traz à luz contrastes. Ao contrário, estabelece uma continuidade...2

Continuidade passado-presente que se expressa de modo flagrante na proposta de tombamento da recém-construída Igreja da Pampulha, projetada no início dos anos 1940 por Oscar Niemeyer em Belo Horizonte e indicada para

\footnotetext{
${ }^{1}$ ANDRADE, Antonio Luiz Dias de. Op. cit., pp. 154.

2 RUBINO, Silvana. "O mapa do Brasil passado", In: Revista do Patrimônio - Cidadania, op. cit., pp. 103.
} 
RESTAURAÇÃO: diálogos entre teoria e prática no brasil nas experiências do iphan 3_restauração na fase moderna do iphan

tombamento no ano de 1947 pelo Diretor da Divisão de Estudos e Tombamentos do SPHAN, arquiteto Lucio Costa. Em sua indicação de tombamento Lucio Costa afirma:

Considerando o estado de ruína precoce em que se encontra a Igreja de São Francisco de Assis, da Pampulha, em Belo Horizonte, devido a certos defeitos de construção e ao abandono a que foi relegado esse edifício pelas autoridades municipais e eclesiásticas;

$[\ldots]$

Considerando, enfim, que o valor excepcional desse monumento 0 destina a ser inscrito, mais cedo ou mais tarde, nos Livros de Tombo, como monumento nacional, e que portanto seria criminoso vê-lo arruinarse por falta de medidas oportunas de preservação, para se haver de intervir mais tarde no sentido de uma restauração difícil e onerosa, tenho a honra de propor, de acordo com os itens I e III do art. 9o do Decreto-lei $n^{\circ} 25$, de 30 de novembro de 1937, o tombamento preventivo da Igreja de São Francisco de Assis, da Pampulha, [... $]^{3}$

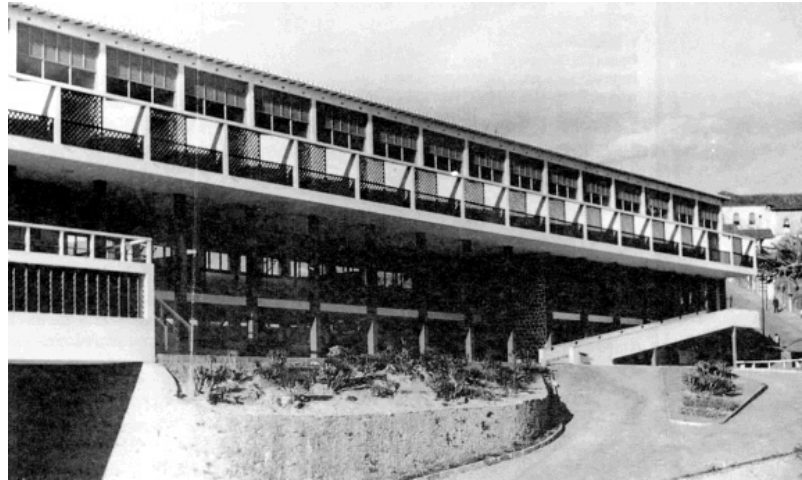

Fig. 15 - Grande Hotel, Ouro Preto. Projeto de Oscar Niemeyer. Fonte: Revista do Patrimônio, n. 22, pp. 112
Também no parecer recomendando a adoção do projeto de Niemeyer para o Grande Hotel, em Ouro Preto (Fig. 15), Lucio Costa estabelece uma linha de continuidade entre a "boa arquitetura do passado" e a "boa arquitetura contemporânea", afirmando:

$\mathrm{Na}$ qualidade de arquiteto incumbido pelos CIAM de organizar o grupo do Rio e na de técnico especialista encarregado pelo SPHAN de estudar a nossa arquitetura antiga, devo informar você, com referência à construção em Ouro Preto do hotel projetado pelo O.N.S. [Oscar Niemeyer Soares], o seguinte:

Sei, por experiência própria, que a reprodução do estilo das casas de Ouro Preto só é possível, hoje em dia, à custa de muito artifíicio. Admitindo-se que o caso especial dessa cidade justificasse, excepcionalmente, a adoção de tais processos, teríamos, depois de concluída a obra, ou uma imitação perfeita, e o turista desprevenido correria o risco de, à primeira vista, tomar por um dos principais monumentos da cidade uma contrafação, ou então, fracassada tentativa, teríamos um arremedo 'neocolonial' sem nada de comum com o verdadeiro espirito das velhas construções.

Ora, o projeto do O.N.S. tem pelo menos duas coisas em comum com elas: beleza e verdade. Composto de maneira clara, direta, sem compromisso, resolve com uma técnica atualíssima e da melhor forma possivel, um problema atual, como os construtores de Ouro Preto resolveram da melhor maneira então possível, os seus próprios problemas. De excepcional pureza de linhas, e de muito equilibrio

${ }^{3}$ COSTA, Lucio. Op. cit., pp. 67-68. Grifo nosso. Márcia Sant'Anna destaca que: "São tombamentos quase simultâneos à inauguração dessas obras [sede do Ministério da Educação e Saúde Pública - MES e Capela da Pampulha], como se elas já nascessem destinadas a se tornar monumentos históricos ou consagradas como obras de arte de valor excepcional. Naturalmente, esses tombamentos fazem parte da estratégia de consagração da arquitetura moderna como arquitetura brasileira por excelência, e consolidação da hegemonia modernista nesse campo" (SANT'ANNA, Márcia. Da cidademonumento..., op. cit., pp. 129). 
plástico, é, na verdade, uma obra de arte e, como tal, não deverá estranhar a vizinhança de outras obras de arte, embora diferentes, porque a boa arquitetura de um determinado período vai sempre bem com a de qualquer período anterior - o que não combina com coisa nenhuma é a falta de arquitetura. ${ }^{4}$

$\mathrm{Na}$ defesa da "boa arquitetura" contemporânea, Lucio Costa desqualifica a imitação ou a contrafação de monumentos, relegando-os à condição de não-arquitetura, ou seja, construção destituída de qualquer valor positivo, ante os quais o projeto de Niemeyer serviria como excelente contraexemplo. Porém, contraditoriamente, em seu parecer sobre o conjunto arquitetônico e urbanístico de Ouro Preto/MG, do ano de 1958, o mesmo arquiteto, a propósito de suas sugestões para "obras de maior vulto relacionadas com a restauração da cidade propriamente dita", sugere que "o tombamento obriga a providências de caráter radical quando se trata de preservar ou repor a coisa no seu estado original" ${ }^{5}$ implicando em demolições e recomposições de fachadas e até mesmo de prédios inteiros, de modo a garantir a ambiência harmônica, resultando em verdadeira falsificação do conjunto edificado da cidade, anulando sua autenticidade e historicidade.

Dessas experiências pode-se inferir o caráter incongruente das tomadas de decisão dos profissionais vinculados ao Patrimônio Nacional ao longo das primeiras décadas de atuação do órgão. Por meio de seus prepostos, a ação da instituição estava ora em consonância com os postulados das teorias da restauração que lhes eram contemporâneas, tais como os conteúdos do restauro filológico ou os princípios da Carta de Atenas (1931), ora retomavam princípios já revistos e descartados por esta, como as reintegrações estilísticas defendidas e praticadas, dentre outros, por Viollet-le-Duc no século XIX.

Tal quadro institucional manteve-se praticamente inalterado até a aposentadoria de Rodrigo M. F. de Andrade, em 1967, quando é substituído por um antigo colaborador do SPHAN, o arquiteto Renato Soeiro.

Ainda que alguns estudiosos ou profissionais especializados tenham questionado certos "abusos" na forma de atuação dos técnicos do Patrimônio nesse período, praticamente todas as ações do órgão revestiam-se da autoridade institucional do IPHAN, que se consolidou ao longo de décadas como única instância responsável pelas ações de constituição e preservação do

${ }^{4}$ Carta de Lucio Costa a Rodrigo Melo Franco de Andrade. Apud: MOTTA, Lia. "A Sphan em Ouro Preto...", op. cit., pp. 109.

${ }^{5}$ COSTA, Lucio. Op. cit., pp. 149. 
patrimônio brasileiro. Todavia, se o IPHAN passou relativamente incólume ao fim da era Vargas, não se pode dizer o mesmo em relação às décadas seguintes. Os anos 1950/1960 foram marcados pela forte alteração no modelo de desenvolvimento brasileiro, com a intensificação da industrialização e do processo de urbanização e crescimento das cidades, transformações de grande impacto na atuação preservacionista, que sofria pressões bastante incisivas de uma sociedade que passara a associar progresso nacional com modernização. Dessa forma, havia que se conciliar valor cultural e valor econômico, mostrando que esses conceitos não eram necessariamente excludentes em relação à preservação de bens do patrimônio. ${ }^{6}$

Além das transformações no modelo de desenvolvimento do país e dos impasses daí decorrentes na ação preservacionista do IPHAN, a crise de legitimidade se acentua ainda mais na passagem da década de 1960 para a de 1970, ocasião em que inúmeras críticas passam a ser feitas à atuação do órgão federal de preservação, considerada dogmática e elitista. Segundo seus críticos, na atuação do SPHAN, a noção antropológica de patrimônio presente no anteprojeto de Mário de Andrade $^{7}$ não fora incorporada ao andamento da

${ }^{6} \mathrm{~A}$ compatibilização entre preservação e desenvolvimento, bem como a utilização do patrimônio cultural como fonte de dividendos, foram ratificadas nas Normas de Quito, produto da Reunião sobre conservação e utilização de monumentos e sítios de interesse histórico e artístico, de 1967, promovida pela Organização dos Estados Americanos. Ver: Normas de Quito - 1967, In: Cartas Patrimoniais, op. cit., pp. 105-122.

7 Em 1936 o ministro Capanema encomendou a Mário de Andrade a elaboração de um anteprojeto para a criação do serviço federal de proteção ao patrimônio. Neste anteprojeto, Mário de Andrade estabelecia que o Serviço do Patrimônio Artístico Nacional - SPAN, teria como função "determinar, organizar, conservar, defender e propagar o patrimônio artístico nacional", entendido como "todas as obras de arte pura ou de arte aplicada, popular ou erudita, nacional ou estrangeira, pertencentes aos poderes públicos, a organismos sociais e a particulares nacionais, a particulares estrangeiras, residentes no Brasil". Estabelecia ainda oito categorias de obras de arte patrimonial: arte arqueológica, ameríndia, popular, histórica, erudita nacional, erudita estrangeira, artes aplicadas nacionais e aplicadas estrangeiras, a serem inscritas em um dos quatro Livros de Tombo: Arqueológico e Etnográfico, que corresponde às três primeiras categorias; Histórico, correspondente à quarta categoria; das Belas Artes, referente à quinta e sexta categorias; das Artes Aplicadas, que incluem a sétima e oitava categorias. Cf.: Proteção e revitalização..., op. cit., pp. 55-68. Por contemplar tanto a arte erudita quanto a popular e ainda incluir a preservação de objetos da cultura popular, manifestações do folclore e costumes, além de paisagens e monumentos, este anteprojeto é considerado por muitos como à frente de seu tempo, em franca oposição ao Decreto-lei n. 25, redigido por Rodrigo M. F. Andrade, considerado elitista e conservador. A esse respeito ver: FONSECA, Maria Cecília Londres. Op. cit., pp. 98-106. Para uma visão diversa, ver também: SANTOS, Cecília Helena Godoy Rodrigues dos. Op. cit., pp. 76-86. Esta autora considera que Mario e Rodrigo, com seus respectivos projetos, são "duas faces solidárias da mesma ação patrimonial, unidas por um ideal e, sobretudo, por um compromisso de trabalho" (SANTOS, Cecília Helena Godoy Rodrigues dos. Op. cit., pp. 85). 
instituição, que com o passar dos anos tecnificou-se cada vez mais, ${ }^{8}$ a ponto de se encontrar completamente isolada política e socialmente, não correspondendo às demandas da sociedade.

O segundo diretor do Patrimônio Nacional, Renato Soeiro, recebe, pois, de Rodrigo a direção de um órgão em crise, considerado por muitos intelectuais e por setores do governo da época como um "elefante branco, uma instituição pouco ágil, [...] reflexo desse patrimônio imóvel ao qual ela esteve voltada durante tanto tempo". ${ }^{9}$

Esta crise de legitimidade enfrentada pelo IPHAN fez com que Renato Soeiro apelasse à UNESCO para um melhor aparelhamento da instituição, através do estabelecimento de acordos de cooperação institucional. ${ }^{10} \mathrm{Fez}$ também com que o IPHAN se abrisse à participação de estados e municípios, descentralizando a política preservacionista brasileira, até então atribuição exclusiva do Governo Federal. Com os Encontros dos Governadores de Estado, ocorridos em 1970 em Brasília e no ano seguinte em Salvador, criam-se condições de cooperação e atuação complementar à do órgão federal de preservação com o compromisso de governadores e dirigentes municipais de atuarem conjuntamente com o IPHAN, procurando atender à crescente demanda pela preservação da memória e de seus suportes materiais. Ademais, procuravase a conciliação entre a "salvaguarda dos valores ambientais" e o "progresso urbano", como proposto nas Normas de Quito, ${ }^{11}$ indicando a aliança entre as políticas de planejamento urbano e de preservação.

É nesse contexto que se estabelece o Programa Integrado de Reconstrução das Cidades Históricas (1973), conhecido como PCH, que tinha como objetivo central dar suporte à exploração turística das cidades históricas e de seus monumentos. "A criação do $P C H$ veio suprir basicamente a falta de recursos financeiros e administrativos do IPHAN, continuando a cargo dessa instituição a referência conceitual e técnica". ${ }^{12}$

${ }^{8}$ Antonio Augusto Arantes, citado em: FONSECA, Maria Cecília Londres. Op. cit., pp. 157.

9 Afirmação de um jornalista em entrevista com Aloísio Magalhães. In: MAGALHÃES, Aloísio. E Triunfo? A questão dos bens culturais no Brasil. Rio de Janeiro: Nova Fronteira; Brasília: SPHAN/Pró-Memória, 1980, pp. 115.116.

${ }_{10}$ A esse respeito ver: MILET, Vera.Op. cit., pp. 163-167.

${ }^{11}$ Normas de Quito - 1967, In: Cartas Patrimoniais, op. cit., pp. 108.

${ }^{12}$ FONSECA, Maria Cecília Londres. Op. cit., pp. 162. 
Também fruto de propostas dos Encontros dos Governadores é a indicação para criação de escolas de formação para restauradores, de modo a capacitar aqueles que viriam a atuar nesta área em expansão. Neste contexto, é organizado um curso de especialização através de convênio firmado entre 0 Condephaat, o IPHAN e a Faculdade de Arquitetura e Urbanismo da Universidade de São Paulo (FAU-USP), visando à formação de especialistas "para atendimento das unidades dos serviços de proteção do Patrimônio Histórico e Artístico do País". ${ }^{13}$ Até este momento não havia sido notada a necessidade de um estudo mais acurado dos princípios da restauração, posto que, conforme já se disse anteriormente, os conhecimentos da arquitetura tradicional e contemporânea eram tidos como suficientes para amparar e estabelecer os parâmetros para a ação preservacionista brasileira. Entretanto, neste curso ficou evidente a defasagem entre as práticas implementadas pelo órgão federal de preservação e os conceitos oferecidos pela teoria da restauração, como se pode perceber na aula dada pelo arquiteto do IPHAN Augusto da Silva Telles, o qual

Depois de apresentar uma perspectiva histórica da noção de valorização do monumento [...] passa a analisar cada um dos artigos da Carta de Veneza, tentando empregar, como exemplos concretos da aplicação das recomendações contidas na Carta, as restaurações empreendidas pelo IPHAN. A tentativa é malograda diante da incompatibilidade evidente entre os princípios da Carta e aqueles adotados nas intervenções mostradas. Nas restaurações do IPHAN estava clara a diretriz original devolver ao edifício a sua feição primitiva -, à custa da supressão dos acréscimos posteriores e, evidentemente, ignorando qualquer orientação do documento de $1964 .{ }^{14}$

Este documento internacional de 1964 consolida as linhas gerais do conceito de monumento e de restauração, tal como se estratificara até aquele momento. Num processo de conformação e consolidação de um campo autônomo de conhecimento, a Carta de Veneza retoma e aprofunda os postulados da Carta de Atenas, de modo a "dotá-los de um alcance maior em um novo documento". ${ }^{15}$ Dessa forma, ressalta-se que, a despeito de haver mais de 30 anos decorridos entre a primeira e a segunda reunião de arquitetos e técnicos de monumentos históricos, a restauração - aqui entendida como campo disciplinar - não "saltou" de um momento para o outro, mas passou por anos de discussão e amadurecimento. Ao contrário do que podem alguns supor, não

${ }^{13}$ Artigo $2^{\circ}$ do Convênio, publicado no Diário Oficial do Estado de São Paulo em 20/12/1972. Ver: MAYUMI, Lia. Taipa, canela preta..., op. cit., pp. 149.

14 Idem, pp 153.

${ }^{15}$ Carta de Veneza - 1964, In: Cartas Patrimoniais, op. cit., pp. 92. 
houve um período de "silêncio" de três décadas, no qual a restauração se "cala", mas um processo contínuo de reflexão, que se debruça e se dirige "para problemas cada vez mais complexos e diversificados", ${ }^{16}$ fruto da ampliação do que se considera patrimônio, que passa a ter a seguinte definição:

A noção de monumento histórico compreende a criação arquitetônica isolada, bem como o sítio urbano ou rural que dá testemunho de uma civilização particular, de uma evolução significativa ou de um acontecimento histórico. Estende-se não só às grandes criações, mas também às obras modestas, que tenham adquirido, com o tempo, uma significação cultural. ${ }^{17}$
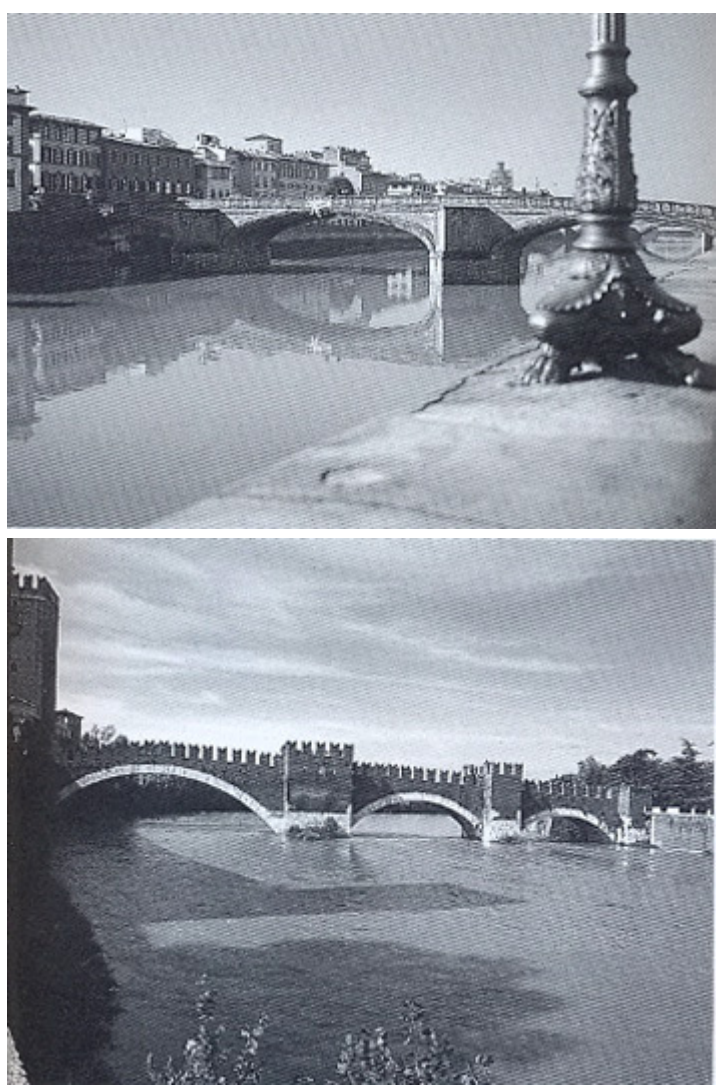

Fig. 16/17 - Dois exemplos de reconstrução "fiel ao original" executadas no segundo pós-guerra. Pontes

Santa Trinita, Florença e Scaligero, Verona. Fonte: MARCONI, 2003, pp. 56.
Dado que os conteúdos expressos na Carta de Veneza representam a consolidação de conhecimentos acumulados até aquele momento em relação à preservação de monumentos, cabe aqui a retomada de alguns dos pontos principais do debate que se desenrolou a partir dos anos 1930 e se consubstanciou no documento de 1964.

Conforme se disse anteriormente, no entreguerras europeu prevalecia a tendência conhecida como restauro filológico, tendo como seu principal expoente Gustavo Giovannoni, cuja postura em relação aos monumentos do passado é certamente uma forma mais respeitosa e ponderada de tratamento e intervenção. No entanto, a escala de devastação trazida pela Segunda Guerra Mundial demonstrou os limites do restauro filológico para se enfrentar novas questões impostas pelos bombardeios intensos em vasta extensão do território europeu. Tratava-se de dar conta de uma realidade de devastação que nada tinha de semelhante com as situações ordinárias de manutenção e restauro de edificações ou áreas urbanas isoladas. A necessidade de reconstrução em massa colocou problemas de ordem prática, mas também metodológica: como intervir em áreas de grande valor histórico e simbólico? Quais critérios adotar? Reconstruir fielmente monumentos e áreas urbanas inteiras como eram antes dos bombardeios (Fig. 16/17) ou utilizando a

\footnotetext{
16 Idem, ibidem.

17 Idem, ibidem.
} 
linguagem arquitetônica contemporânea? Procurar um "meio-termo", inserindo novos elementos com formas simplificadas sem, contudo, romper com a escala $\mathrm{e}$ a relação com o território previamente existente? Ou ainda, deixar as áreas devastadas como áreas livres, espaços públicos, sem optar pela reconstrução?

Todas essas formas de intervir foram de algum modo adotadas na Europa devastada pelas bombas e seus resultados suscitaram um amplo debate, especialmente durante as décadas de 1950 e 1960, sobre a pertinência de se inserir elementos de fatura contemporânea em áreas históricas consolidadas e as relações destes com a pré-existência. Esse debate se deveu tanto à extensão dos danos de guerra quanto à igualmente volumosa especulação imobiliária que se sucedeu. Renato De Fusco recupera algumas contribuições teóricas deste intenso debate no ambiente italiano dos anos 1950/60, como se verá a seguir. ${ }^{18}$

Cesare Brandi coloca a impossibilidade de convívio entre uma arquitetura que, por princípio, rompe com a realidade perspéctica das arquiteturas antigas. Para Brandi, a inserção de uma arquitetura moderna pensada como um prisma isolado e elevado sob pilotis - em centros históricos consolidados só pode dar-se à custa de sacrificar ou a própria arquitetura moderna, dado que esta deve negar suas propriedades intrínsecas para se adaptar ao ambiente onde será inserida, ou sacrificando este ambiente, que se veria invadido por um "alienígena", um elemento completamente estranho às suas características naturais. ${ }^{19}$

Já para Roberto Pane, a coexistência entre antigo e novo seria uma possibilidade real principalmente como garantia da conservação do antigo, o qual de outro modo se veria relegado ao abandono. Para este autor, "Ė necessario che l'ambiente sia sentito come un'opera collettiva da salvare in quanto tale", não com a conservação absoluta, musealizando os centros antigos, mas estabelecendo uma convivência a partir do "rapporto di masse e di spazi che

18 DE FUSCO, Renato. Dov'era ma non com'era. II patrimonio architettonico e l'occupazione. Firenze: Alinea, 1999, pp. 18 e ss.

${ }^{19}$ Além da referência a De Fusco, ver também: Cesare Brandi, que no seu Arcadio o della Scultura. Eliante o dell'Architettura, afirma: "Continuare l'assurdo di inserire edifici modernistici, più o meno castrati per potere rientrare nei limiti catastali dell'area e dell'alzato, significa produre dei cancri architettonici la cui distruttività, sui vecchi tessuti urbani, s'avvera catastrofica [...] O si fanno dei quartieri integralmente moderni e si rispettano quegli antichi, oppure la nostra civiltà continuerà a distruggere se stessa, anche dove crede di salvare qualche residuo". Apud: CARBONARA, Giovanni. Avvicinamento..., op. cit., pp. 314, nota 7. 
consenta la sostituzione di un elemento antico con un nuovo purchè esso sia subordinato al rapporto suddetto". ${ }^{20}$

Igualmente defensor da coexistência antigo-novo, E. N. Rogers alerta que não se pode negar à contemporaneidade 0 direito de se expressar e de deixar suas marcas no território, defendendo, portanto, a convivência entre obras do passado e novas.

Leonardo Benévolo defende a manutenção das estruturas antigas a partir da atribuição de novos usos, os quais devem ser pensados em função (e não em detrimento) desses monumentos. Esta idéia da manutenção das estruturas antigas, adaptadas a um novo uso proposta por Benévolo é compartilhada por Giulio Carlo Argan, o qual reclama a utilização como habitação popular a mais adequada. Aldo Rossi defende a construção de uma cidade moderna na qual se mantenham elementos marcantes do passado, que permaneçam como referências singulares do espaço urbano.

Interessante nesse debate é a postura do arquiteto Bruno Zevi, que num primeiro momento contradiz radicalmente as colocações de Cesare Brandi, pois para ele "A visão perspéctica não significa a segurança de que haja a unidade formal e a harmonia de convivência entre as arquiteturas das várias épocas", ${ }^{21}$ sendo, portanto, possível e até desejável a convivência antigo-novo. Porém, passados alguns anos, diante da constatação de que o resultado para as cidades foi de "recíproco deterioro das duas partes: a arquitetura antiga torna-se totalmente deturpada pela inserção do novo, assim como a arquitetura moderna tentar sustentar um diálogo inexistente",22 passando portanto a negar completamente a possibilidade de coexistência.

Também nos anos 1950, um outro debate se debruça sobre questões semelhantes, mas a partir de pontos de vista bastante diversos. Arquitetos e urbanistas do CIAM, durante o primeiro encontro após o fim da II Guerra Mundial, reunidos em Hoddesdon em 1951, adotam como tema "O coração da cidade". ${ }^{23}$ Já nos congressos anteriores, a questão das relações de vizinhança e de escala, assim como a relação com o passado e os centros cívicos e de convivência vinham aparecendo sub-repticiamente. Os problemas das

20 DE FUSCO, Renato. Op. cit., pp. 20.

21 OLIVEIRA, Raíssa Pereira Cintra de. Op. cit., pp. 55.

22 Idem, pp. 56.

${ }^{23}$ ROGERS, Ernesto Nathan.; SERT, Josep Lluís; TYRWHITT, Jaqueline. (a cura di). II cuore della città. Per una vita più umana delle comunità. Milano: Hoelpi, 1954. 
metrópoles, que cresciam vertiginosamente para periferias cada vez mais afastadas, com a conseqüente deterioração dos centros tradicionais, e a reconstrução pós-bélica eram igualmente pontos a serem enfrentados pelo CIAM. Portanto, no VIII CIAM, emerge como tema principal os centros cívicos, os lugares ou elementos na cidade que identificam uma comunidade como comunidade. ${ }^{24}$ Conforme relata Giedion,

Può darsi che noi siamo stati indotti a discutere questo tema $[0$ coração da cidade] da avvenimenti esterni, ma io credo piuttosto che sia una nostra urgenza interiore quella che ci spinge verso un processo di umanizazione del nostro ambiente e che sia proprio questa urgenza a condurci sul sentiero che stiamo ora seguendo. ${ }^{25}$

Para os organizadores do VIII CIAM, o grupo britânico MARS (Modern Architectural Research Group),

$[$ [...] the theme was relevant both to the design of pedestrian civic centers in new towns like Stevenage, [...] and to the issue of modern urban celebrations like the Festival of Britain, which opened two months before CIAM and ran concurrently with it. The theme was also relevant to the rebuilding of bombed city centers, such as the one being reconstructed at Convetry. ${ }^{26}$

O "coração" é assumido como lugar que caracteriza e distingue uma cidade das outras e que fixa esta personalidade nas memórias de seus habitantes e dos visitantes que por ela venham a passar. Como adverte Richards, ${ }^{27}$ esta personalidade não se formou de uma vez por todas, definitivamente, mas através de um processo histórico longo de transformação, portanto, a dificuldade para os urbanistas é estabelecer a justa medida para que esta transformação possa continuar na dinâmica da cidade moderna, "per poter avere la sicurezza che la personalità della città sarà conservata oppure sarà trasformata in un'altra, diversa ma altrettanto vitale". ${ }^{28}$ Ainda esse mesmo autor coloca, em harmonia com aquele debate apresentado em antecedência, que 0 respeito às antigas edificações e sua conservação é "un modo di mantenere la continuità dell'esperienza umana" e, por isso, a inserção de novos elementos nessas áreas, quando necessários (como nos casos de áreas bombardeadas, mas não completamente destruídas), devem manter a harmonia do lugar, mas

${ }^{24}$ MUMFORD, Eric. The CIAM discourse on urbanism, 1928-1960. Cambridge: MIT Press, 2002, pp. 203.

${ }^{25}$ GIEDION, S. "I precedenti storici", In: ROGERS, Ernesto Nathan.; SERT, Josep Lluís; TYRWHITT, Jaqueline. (a cura di). Op. cit., pp. 17.

${ }^{26}$ Idem, ibidem.

${ }^{27}$ RICHARDS, J. M. "Elementi vecchi e nuovi nel Cuore della città", In: ROGERS, Ernesto Nathan.; SERT, Josep Lluís; TYRWHITT, Jaqueline. (a cura di). Op. cit., pp. 60.

28 Idem, ibidem. 
sem "costruire edifici nuovi in stile antico o adattarsi ai vari altri compromessi di questo genere". 29

Se o tom do discurso parece unificar as posturas dos arquitetos ligados ao CIAM com aqueles ligados à preservação dos monumentos, tradicionalmente colocados em campos opostos, como já se fez aceno no capítulo anterior, ainda persiste uma clara e determinante divergência entre eles: o ponto de partida e foco central da preservação está no monumento, que, ao contrário, é entendido

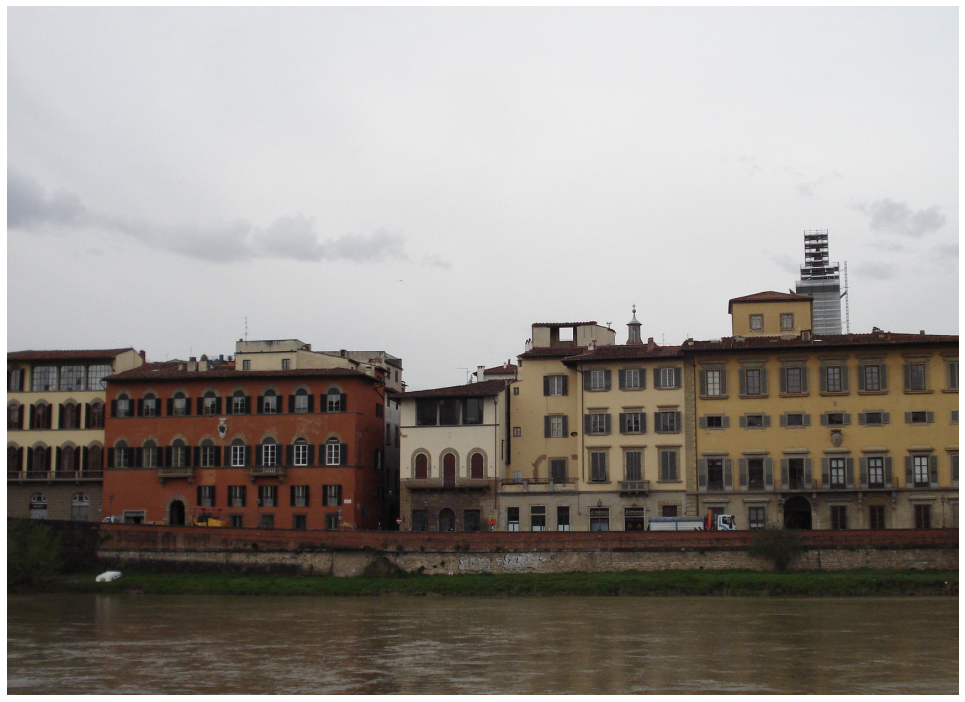

Fig. 18 - Florença, Lungarno Guicciardini. Exemplo de reconstrução mantendo a volumetria pré-existente. Foto: Claudia Reis, 2009.

pelos arquitetos modernistas como um cenário de fundo para inserção do novo elemento. ${ }^{30} \mathrm{~A}$ diferença parece ser, portanto, a de projetar na pré-existência e para a préexistência, cujo desdobramento prático é totalmente distinto em um caso e noutro. Assim, parece importante retomar o discurso a partir do ponto de vista da preservação.

No segundo pós-guerra inúmeras críticas se voltavam para os princípios do restauro filológico, fundamentalmente contra a consideração dos monumentos exclusiva ou preponderantemente como documentos históricos, ignorando sua realidade figurativa; uma outra crítica recaía sobre o chamado "moderno-ambientado", uma forma de construir largamente adotada durante a reconstrução pós-bélica que consistia na adoção de formas arquitetônicas que repetiam a escala e implantação antigas, porém simplificando detalhes construtivos (Fig. 18). Estas construções se pretendiam "neutras", mas capazes de reintegrar o tecido urbano fragmentado. ${ }^{31}$

\footnotetext{
29 Idem, ibidem.

30 Idem, pp. 63.

${ }_{31}$ CARBONARA, Giovanni. Avvicinamento..., op. cit, pp. 285. É especialmente contra o moderno ambientado que Brandi e, mais tarde, Zevi se voltam. Para eles, essas construções não são nem uma coisa, nem outra, nem antigas e nem modernas, e ao contrário de reintegrar as lacunas do espaço urbano, recuperando-o, apenas denigrem sua imagem.
} 
Baseada na noção de que a obra arquitetônica é uma obra de arte, portadora de uma imagem figurativa, ${ }^{32}$ as críticas rechaçavam a validade de "neutros" como substitutos a obras de arte de grande qualidade destruídas pela guerra. Nenhuma arquitetura verdadeira poderia ser neutra; nenhuma intervenção no contexto urbano poderia passar despercebida, pois necessariamente se constituiria num elemento do conjunto, o mais das vezes inclusive com ressonâncias negativas sobre este ambiente, dado que desprovido de valor artístico. Dessa reflexão desponta um novo repensar sobre os princípios do restauro de monumentos, que tomará corpo com o pensamento de arquitetos e historiadores da arquitetura, tais como Renato Bonelli (1911-2004) e Roberto Pane (1897-1987), consolidando os postulados do chamado restauro crítico. ${ }^{33}$

O restauro crítico nega que os monumentos históricos possam ser enquadrados em categorias previamente determinadas ou esquemas e regras pré-concebidos, como cria o restauro filológico, afirmando que cada obra é única em sua conformação e devir no tempo e exige, por isso, soluções únicas. Tais soluções devem advir de uma atenta análise do monumento, uma indagação baseada na crítica e na história com vistas a determinar sua qualidade estética. Portanto, o restauro não pode ser admitido como atividade empírica, oriundo de exigências práticas, mas somente como ato cultural fundamentado na história $\mathrm{e}$ na estética. Conforme apresenta Bonelli, o restauro crítico parte do reconhecimento de que:

un'opera architettonica non è solo un documento, ma è soprattutto un atto che nella sua forma esprime totalmente un mondo spirituale e che essenzialmente per questo assume importanza e significato. Essa rappresenta per la nostra cultura il grado più alto proprio per il suo valore artistico e appunto da questa fondamentale considerazione sorge il nuovo principio informatore del restauro: assegnare al valore artistico la prevalenza assoluta rispetto agli altri aspetti e caratteri dell'opera, i quali devono essere considerati solo in dipendenza ed in funzione di quell'unico valore. ${ }^{34}$

Admitindo que a arquitetura seja, portanto, obra de arte, o restauro só pode partir da indagação diretamente sobre a obra em questão de suas qualidades artísticas, definida a partir de um "atto critico, giudizio fondato sul criterio che identifica nel valore artistico, e perciò negli aspetti figurali, il grado

32 BONELLI, Renato. Scritti sul restauro e sulla critica architettonica. Roma: Bonsignori Editore, 1995, pp. 17.

${ }^{33}$ CARBONARA, Giovanni. Avvicinamento..., op. cit, pp. 285 e ss.

${ }^{34}$ BONELLI, Renato. "Verbete: II Restauro...", op. cit., pp. 347. 
d'importanza ed il valore stesso dell'opera". ${ }^{35}$ A partir deste reconhecimento, o papel do restaurador é o de "recuperare, restituendo e liberando, l'opera d'arte, vale a dire l'intero complesso di elementi figurativi che costituiscono l'immagine ed atraverso $i$ quali essa realizza ed esprime la propria individualità e spiritualità". 36

O valor histórico, praticamente a única instância contemplada no restauro filológico, não pode ser a razão exclusiva e nem guiar a intervenção restauradora, na medida em que escamoteia o valor artístico constitutivo dos

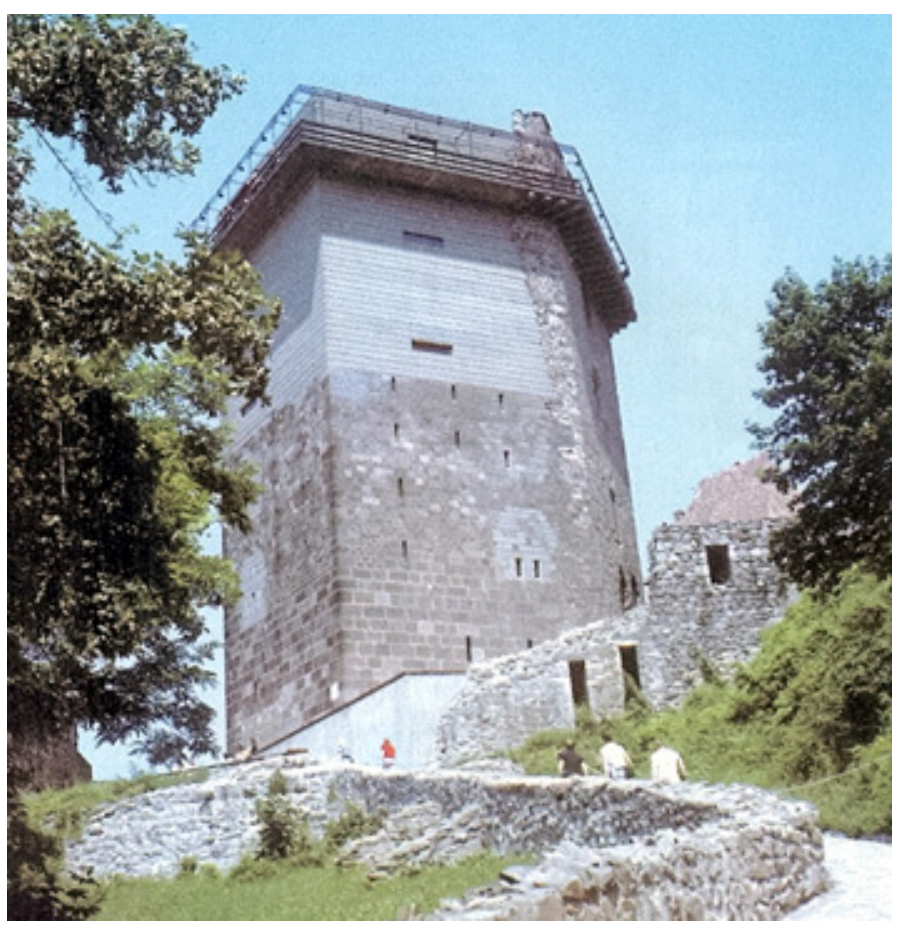

Fig. 19 - Torre Salomão, Visegrád. Reintegração da imagem sem mimetismo. Restauro de J. Sedlmayr (1963-66). Fonte: CARBONARA, 1997, pp. 247. monumentos e a função social que este valor tem.

\section{Para os defensores do} restauro crítico, além de um processo crítico (que percorre toda a duração da operação de restauro e não apenas 0 primeiro momento), o restauro se caracteriza também como processo criativo, na medida em que:

quando il ripercorrimento dell'immagine condotto sulla forma figurata risulta interrotto da distruzioni o ingombri visivi, il processo critico è costretto a valersi della fantasia per ricomporre le parti mancanti o riprodurre quelle nascoste e ritrovare infine la compiuta unità dell'opera, anticipando la visione del monumento restaurato. ${ }^{37}$

A recomposição da unidade figurativa da obra, tal como proposta pelo restauro crítico, não se confunde com a unidade estilística, à moda de Viollet-le-Duc, ao contrário, é sempre subordinada à análise crítica e limitada às possibilidades oferecidas pelo próprio monumento (Fig. 19). Igualmente a criatividade do restaurador não significa uma total liberdade de criação, mas um processo sempre condicionado pela realidade material da obra e no respeito absoluto desta. Não se trata, portanto, de um gesto personalista, mas de uma criatividade sempre subordinada ao objetivo da conservação e transmissão ao futuro do bem cultural. A extensão dos danos sofrida pela obra arquitetônica

\footnotetext{
35 Idem, ibidem.

36 Idem, ibidem.

37 Idem, ibidem.
} 
deve dar a justa medida ao restaurador, o qual avaliará a possibilidade e a pertinência da empreitada, consciente de que:

All'argomento principale che il valore assoluto dell'opera distrutta, quello dell'arte, è perduto e non è più recuperabile, si aggiungono l'inutilità e si potrebbe dire l'immoralità di eseguire un restauro che è un vero e proprio falso estetico-storico, culturale e documentario, e che come tale non può arricchire la nostra anima e la nostra coscienza, non potento ricreare il passato; è un atto, quindi, sotto ogni aspetto, antistorico e vano. ${ }^{38}$

Contrapondo-se às reconstruções repristinatórias ou no estilo "modernoambientado" executadas no pós-guerra, Bonelli coloca que se a destruição alcança uma tal monta, de maneira a romper definitivamente com a qualidade estético-figurativa da arquitetura, esta não pode ser recomposta, daí a proposição de deixá-la "in uno stato non molto dissimile da quello in cui lo hanno lasciato le bombe o le mine", dado que seja impossível ressuscitar 0 monumento. ${ }^{39}$

Ampliando o interesse daqueles monumentos de reconhecido valor artístico para aquelas obras de "arquitetura menor", isto é, construções que isoladamente não possuem grande valor estético, mas que são, em conjunto, coformadoras do ambiente urbano, Bonelli caracteriza o restauro urbanístico. Segundo 0 autor, o interesse pelo conjunto urbano, incluindo-se aí a chamada arquitetura menor, surge a partir de um processo que se desenvolve nos últimos decênios do século XIX, partindo da análise dos grandes monumentos isolados, estendendo-se ao ambiente onde estes se inserem, depois aos monumentos menos importantes, aos conjuntos arquitetônicos e, enfim, contemplando todo 0 núcleo antigo das cidades e a própria cidade em sua inteireza e complexidade. ${ }^{40}$ Esse processo de ampliação da noção de monumento, que parte do objeto isolado e passa a enquadrar a arquitetura menor e os chamados centros históricos, é o foco das atividades do II Congresso Internacional de Arquitetos e Técnicos de Monumentos Históricos, ocorrido em 1964 e que deu origem ao conhecido documento que é a Carta de Veneza.

Paralelamente ao restauro crítico, outro aporte teórico-metodológico de importância capital para o campo da restauração foi trazido por Cesare Brandi (1906-1988). Autor multifacetado, que transita em diversas disciplinas, Brandi foi provavelmente 0 mais bem-sucedido no intento de tirar a restauração

\footnotetext{
${ }^{38}$ BONELLI, Renato. Scritti sul restauro..., op. cit., pp. 24.

39 Idem, ibidem.

40 BONELLI, Renato. "Verbete: II Restauro...", op. cit., pp. 349.
} 
definitivamente do empirismo, integrando-a às ciências. Toda sua produção teórica tem como base um núcleo comum de conhecimento que integra a estética, a filosofia, a historiografia, a crítica de arte e a restauração.

À frente do Instituto Central de Restauração de Roma (ICR), órgão estatal fundado ainda nos anos da guerra, Brandi coordena a restauração de inúmeras obras de arte destruídas nos bombardeios e, paralelamente, desenvolve sua Teoria da Restauração, ${ }^{41}$ na qual delimita preceitos teóricos que servirão de embasamento à prática do restaurador. Sua análise do restauro não parte da obra em si ou de sua realidade material, mas, através de um percurso dedutivo, passa da esfera do pensamento filosófico à prática, isto é, busca a "conformação de um enunciado teórico sistemático do problema do restauro, traduzível numa metodologia concreta e em princípios operacionais válidos". ${ }^{42}$

A publicação da Teoria em 1963, rapidamente transformada em referência no campo do restauro e que viria a tornar-se o livro mais difundido de Brandi, não significa que esta seja a primeira ocasião em que o autor sistematize seus pensamentos teóricos sobre a restauração. ${ }^{43} \mathrm{~A}$ unidade conceitual de seu pensamento sobre a arte e, conseqüentemente, nos meios para sua preservação de modo responsável, perpassa todos os seus escritos. De fato, sua extensa produção teórica tem como base um núcleo comum de conhecimento, um sistema de pensamento que se desenvolve no tempo, e integra a estética, a filosofia, a historiografia, a crítica de arte e a restauração.

Brandi reconhece na obra de arte, como produto especial da ação humana, duas instâncias: a estética e a histórica; ${ }^{44}$ diante delas, assim como defendido pelos partidários do restauro crítico, sustenta a prevalência da instância estética sobre a histórica nas intervenções de restauro, pois condiciona 0 ato de restauração à compreensão / experimentação da obra de arte enquanto tal, na medida em que é exatamente a condição de artística o que diferencia a obra de arte de outros produtos comuns da ação humana. A Teoria da Restauração de Brandi foi escrita para obras de arte, de onde descende a

\footnotetext{
${ }^{41}$ BRANDI, Cesare. Op. cit.

${ }^{42}$ CARBONARA, Giovanni. "Brandi e a Restauração Arquitetônica Hoje", In: Desígnio Revista de História da Arquitetura e do Urbanismo. São Paulo: FAUUSP / Annablume, n. 6 , nov/2007, pp. 35.

${ }^{43}$ CORDARO, Michele. "Restauro e tutela...", op. cit., pp. 55-61.

${ }^{44}$ Brandi coloca que a instância estética "corresponde ao fato basilar da artisticidade pela qual a obra de arte é obra de arte"; já a instância histórica advém do fato de a obra ser "produto humano realizado em um certo tempo e lugar e que em um certo tempo e lugar se encontra". BRANDI, Cesare. Op. cit., pp. 29.
} 
definição do conceito de restauro apresentada como: "o momento metodológico do reconhecimento da obra de arte, na sua consistência física e na sua dúplice polaridade estética e histórica, com vistas à sua transmissão para o futuro". 45 Como já se afirmou em capítulos anteriores, ao contrário do que muitos supõem, embasar o conceito de restauro no reconhecimento da obra de arte como tal não significa restringir a possibilidade de atuar na manutenção e transmissão ao futuro apenas de obras de arte. Significa afirmar que só se passa do pré-conceito ao verdadeiro conceito de restauro quando um valor de arte (ou mais recentemente se diria de cultura) é atribuído a um dado objeto e que, nesse caso, a funcionalidade não está em questão e sim sua manutenção como bem cultural. ${ }^{46}$

De seu conceito de restauro Brandi extrai dois axiomas:

$1^{\circ}$ axioma: "restaura-se somente a matéria da obra de arte",47

$2^{\circ}$ axioma: "A restauração deve visar ao restabelecimento da unidade potencial da obra de arte, desde que isso seja possível sem cometer um falso artístico ou um falso histórico, e sem cancelar nenhum traço da passagem da obra de arte no tempo",48

Estes dois axiomas corroboram com princípios já postos pelo restauro crítico, numa clara convergência de pensamento. 0 primeiro diz respeito à consistência física da obra, onde tem lugar a manifestação da imagem: "Para que essa consistência material possa durar o maior tempo possível, deverão ser feitos todos os esforços e pesquisas", garantindo, assim, transmitir para o futuro a "possibilidade dessa revelação". $49 \mathrm{~A}$ atenção à matéria da obra de arte não implica em desconsiderar 0 ambiente em que a obra está inserida, pois como esclarece Brandi em relação ao Partenon, "seria inexato sustentar que para o Partenon foi usado como meio físico apenas o pentélico, porque não menos do que o pentélico, é matéria também a atmosfera e a luz em que está", portanto, a remoção de uma obra de seu local de origem só pode ser feita "pela única e superior causa da sua conservação". ${ }^{0}$

O segundo axioma estabelece a principal função da restauração: recuperar a imagem figurada da obra de arte, impondo igualmente seus limites - tal

\footnotetext{
45 Idem, pp. 30.

${ }^{46}$ Como esclarece o próprio Brandi na abertura de sua Teoria. Ver: BRANDI, Cesare. Op. cit., pp. 25-28.

47 Idem, pp. 31.

${ }^{48}$ Idem, pp. 33.

49 Idem, pp. 30-31.

50 Idem, pp. 40.
} 
recuperação não poderá ser feita às expensas da instância histórica, que deverá ser sempre respeitada. Do ponto de vista histórico, "a intervenção voltada a retraçar a unidade originária, [...] deve limitar-se a desenvolver as sugestões implícitas nos próprios fragmentos ou encontráveis em testemunhos autênticos do estado originário". ${ }^{51}$ Assim como em relação à instância estética, os limites da ação do restaurador estão postos em função da matéria original da obra de arte e das sugestões apresentadas pelos fragmentos desta, pois a realidade da obra de arte é distinta da realidade do mundo existencial, em consequêencia, não se pode atuar sobre a obra mutilada por analogia. ${ }^{52}$ Desse modo, relega-se a falsos estéticos e a falsos históricos quaisquer reconstruções que visem recuperar 0 monumento em seu "esplendor original", que

[...] cessa di essere tale nel momento stesso in cui l'opera, appena compiuta dal suo artífice, viene introdotta nel flusso temporale e incomincia, da un lato, ad alterarsi fisicamente in maniera irreversibile e dall'altro a "parlare" diversamente per "le condizione psicologiche che si sono mutate atraverso la storia".

A Carta de Veneza também apresenta a preocupação de retirar a prática da restauração do empirismo, tratando-a nos moldes do restauro crítico, ${ }^{54}$ em que 0 respeito tanto ao documento histórico quanto à matéria original deveriam ser garantidos através da "colaboração de todas as ciências e técnicas que possam contribuir para o estudo e salvaguarda do patrimônio monumental". ${ }^{55}$ Afirma também, corroborando as idéias brandianas, que a restauração "termina onde começa a hipótese". 56

Brandi define como princípios para intervenção três aspectos fundamentais:

1. "a integração deverá ser sempre e facilmente reconhecível; mas sem que por isto se venha a infringir a própria unidade que se visa a reconstruir"; 57

2. "a matéria de que resulta a imagem [...] é insubstituível só quando colaborar diretamente para a figuratividade da imagem como aspecto e não para aquilo que é estrutura";58

\footnotetext{
51 Idem, pp. 47.

52 Idem, pp. 46-47.

53 CARBONARA, Giovanni. La reintegrazione..., op. cit., pp. 144.

54 Deve-se destacar a participação ativa de um dos principais defensores do restauro crítico, Roberto Pane, nos trabalhos do Congresso de Veneza, o qual inclusive proferiu a Conferência Introdutória. Vide: PANE, Roberto. "Conférence introductive", In: Le monument pour l'homme. Actes du II Congrès International de la Restauration. Venezia: ICOMOS, 1964.

55 Carta de Veneza - 1964, In: Cartas Patrimoniais, op. cit., pp. 92.

56 Idem, pp. 93.

57 BRANDI, Cesare. Op. cit., pp. 47.
} 
3. "que qualquer intervenção de restauro não torne impossivel mas, antes, facilite as eventuais intervenções futuras". 59

Tais aspectos permanecem de extrema atualidade e definem a pertinência sempre relativa de qualquer intervenção restauradora e a responsabilidade daí derivada. Os três princípios exigem conhecimento aprofundado da obra em sua realidade material e histórica, além de sensibilidade estética, posto que mesmo distinguível, a integração não deve competir ou estar em conflito com a obra restaurada; a intervenção deve ser reversível, facilitando intervenções futuras e soluções que novas pesquisas demonstrarem mais adequadas. Portanto, a restauração é sempre uma ação do presente e que tem como horizonte, não um retorno ao passado, e sim as gerações futuras, a possibilidade de fruição de um bem cultural de modo íntegro e autêntico, ainda que marcado pela passagem do tempo.

No tocante às ruínas, definidas por Brandi como "tudo aquilo que é testemunho da história humana, mas com um aspecto bastante diverso e quase irreconhecível em relação àquele de que se revestia antes",60 "a restauração [...] só pode ser a consolidação e conservação do status quo, ou a ruína não era uma ruína, mas uma obra que ainda continha uma vitalidade implícita para promover uma reintegração da unidade potencial originária". As ruínas configuram-se, portanto, como caso limite para a ação do restaurador, na qual a ação deve concentrar-se principalmente "[em] uma intervenção indireta que concerne ao espaço-ambiente da ruína".61 Princípio reafirmado pela Carta de Veneza em seu artigo 15, que diz: "Devem ser assegurados o ordenamento das ruínas e as medidas necessárias à conservação e proteção permanentes dos elementos arquitetônicos e dos objetos descobertos".62

Segundo Brandi, ${ }^{63}$ em relação à manutenção ou supressão das adições e reconstruções sofridas pela obra de arte ao longo do tempo surgem conflitos. A instância histórica determina a manutenção de todas as adições e reconstruções da obra de arte, considerando-as como fatos históricos (exatamente como propunha o restauro filológico). Já a instância estética considera toda adição e reconstrução uma interferência na leitura da obra de arte e, daí, em tese,

\footnotetext{
58 Idem, pp. 48.

59 Idem, Ibidem.

60 Idem, pp. 65.

61 Idem, pp. 66.

62 Carta de Veneza - 1964, In: Cartas Patrimoniais, op. cit., pp. 94.

63 BRANDI, Cesare. Op. cit., pp. 63-89.
} 
determinaria sua eliminação. Em seguida, o autor apresenta, porém, uma série de considerações do porquê preservar as adições também do ponto de vista estético, avaliando que só deveriam ser removidas se, ao terem sido concebidas, não tivessem levado em consideração o texto formal da obra de arte. Isto é, separam-se aqueles elementos que fazem parte da história do monumento, ou seja, elementos adicionados ao longo de sua vida e que lhe deram uma nova configuração, enriquecendo-o, daqueles que são sua crônica, quer dizer, elementos que não se fundiram à imagem original do bem cultural formando com ele uma nova realidade artística, ao contrário, denegrindo-0. ${ }^{64}$

Em relação à pátina, esta deve ser mantida por conter em si a historicidade da obra, o que, em princípio, contraria a instância estética, pois a pátina é entendida como uma adição. Entretanto, sua manutenção é requerida também pela instância estética de modo a evitar uma preponderância da matéria sobre a imagem da obra de arte.

Diante da complexidade e da necessidade de conciliar a "dúplice polaridade estética e histórica" inerente a cada monumento, o que deve guiar a intervenção é, portanto, um juízo crítico de valor, idéia presente já no pensamento de Riegl e que aparece também no restauro crítico e na Carta de Veneza, ainda que com a seguinte ressalva: "O julgamento do valor dos elementos em causa e a decisão quanto ao que pode ser eliminado não podem depender somente do autor do projeto".65 Daí a afirmação da restauração como processo coletivo, que não pode depender do gosto ou do arbítrio de um único indivíduo.

O II Congresso Internacional de Restauração, que daria origem à Carta de Veneza, contou com a participação de um representante brasileiro, Vladimir Alves de Souza, que apresentou a conferência "A restauração dos monumentos no Brasil", na qual cita algumas das ações do Patrimônio Nacional na recuperação de "obras-primas da arquitetura religiosa barroca, de importantes monumentos civis e militares'66 nos estados de Minas Gerais, Bahia, Pernambuco e São Paulo, além da consolidação das ruínas de São Miguel das Missões.

${ }^{64} \mathrm{Cf}$. CORDARO, Michele. "Restauro e tutela...", op. cit., pp. 68.

${ }^{65}$ Carta de Veneza - 1964, In: Cartas Patrimoniais, op. cit., pp. 94.

${ }^{66}$ SOUZA, Vladimir Alves. "La restauration des monuments au Brésil", In: Le monument pour l'homme..., op. cit. 
Entretanto, ao que parece, apenas na década de 1980, portanto vinte anos após a aprovação da Carta de Veneza, é que a noção de valor histórico e de sítio urbano passa a ser realmente priorizada nos critérios de seleção dos bens a serem tombados no Brasil, como atesta o crescimento da proteção de áreas urbanas. ${ }^{67}$ Essa ampliação do objeto patrimonial pode ser entendida não apenas como reflexos da Carta de Veneza ou de outras normativas internacionais, como também fruto de mudanças nos conceitos de história operados pelos agentes do patrimônio, a par com a renovação desta disciplina, trazida principalmente com a Nova História. 68

Mas o crescimento no número de tombamentos de conjuntos urbanos em relação aos monumentos isolados - por décadas alvo quase exclusivo na política de tombamentos do IPHAN -, não alterou grandemente a forma "clássica" de intervenção nos bens tombados. A prática de reconstruções no "estilo patrimônio" conservou-se inalterada durante muito tempo ainda em Ouro Preto e Diamantina, por exemplo. ${ }^{69}$ Nesses casos, como em outras cidades históricas tombadas pelo IPHAN, privilegiou-se uma leitura fachadista da arquitetura em detrimento de uma compreensão do fato urbano em sua complexidade, conservando-se a leitura da "cidade-monumento", na qual deviam ser coibidas as mudanças "descaracterizadoras", por oposição à idéia de cidade como uma ambiência na qual se desenrolam as ações de múltiplos agentes sociais ao longo do tempo. Portanto, ainda que a Carta de Veneza seja constantemente invocada para justificar a preservação dos conjuntos urbanos, quando se trata de restaurá-los, as ações estão em claro conflito com seus pressupostos, tal como se pode notar no caso de Ouro Preto. Lia Mayumi,

${ }^{67}$ Mesmo sendo o Brasil pioneiro no tombamento de cidades históricas, como atesta 0 caso de Ouro Preto, já mencionado, essa prática não representa até os anos 1980 o grosso dos tombamentos do IPHAN. A esse respeito ver: SANT'ANNA, Márcia. Da cidade-monumento..., op. cit., pp. 224. Uma outra observação que cabe aqui é o fato de que mesmo nos casos de tombamentos de cidades ou áreas urbanas, geralmente 0 valor destacado era o artístico, isto é, a cidade era tomada como um grande objeto de valor excepcional e não um acúmulo de tempos históricos, por isso, apenas aqueles conjuntos considerados íntegros e homogêneos eram tombados.

68 Sobre a Nova História, ver principalmente: LE GOFF, Jacques. "História", In: História e Memória..., op. cit., pp. 129-132.

69 Lia Motta afirma que: "Os mesmos critérios do início da atuação da instituição continuaram a ser empregados, a mesma forma de trabalho sobreviveu. Os técnicos arquitetos continuaram o exame caso a caso, verificando se estaria garantido o aspecto colonial. No afã de controlar a possível criatividade dos novos arquitetos que chegavam à instituição [...] foram retomadas as normas mais rígidas, já sob forma de cartilha, listando os detalhes que deveriam ser empregados na construção". Ver: MOTTA, Lia. "A Sphan em Ouro Preto...", op. cit., pp.120. Sobre Diamantina, ver: D'ASSUMPÇÃO, Livia Romanelli. Op. cit., pp. 149-196. 
analisando diversos casos de reformas e propostas de novas construções em Ouro Preto, afirma:

Nos anos '70 há uma explosão urbana [em Ouro Preto] que tem como conseqüência a ocupação intensa das encostas de morro ao redor da cidade. E se a cidade tinha cerca de 1.000 edificações à época do tombamento [em 1938], 3.000 novos projetos tinham sido aprovados até 1985, número que sobre para 4.000 até 1995. Apesar das mudanças visíveis, o órgão continuou a aplicar o mesmo critério de análise nos projetos novos que iam surgindo, e além disso aprimorando os detalhes de tratamento de fachadas... ${ }^{70}$

\section{E a autora continua:}

Note-se que o mesmo critério era adotado tanto na área consolidada, [...] como nas áreas de expansão [...], que tiveram que se sujeitar aos padrões estilísticos das edificações da cidade barroca, constituindo bairros inteiros de falsa aparência barroca. Aspectos de projeto como a ocupação dos fundos de lote e destruição dos quintais verdes, quebra das linhas de cumeeira, empenas desencontradas e recuos das divisas do lote não mereceram análise, em nenhum dos casos. ${ }^{71}$

Ao longo de muitas décadas de ação institucional ignorou-se, pois, a máxima de que em restauro cada caso é um caso particular, a demandar soluções únicas e específicas, impossibilitando a simples aplicação de regras estabelecidas por meio de cartilhas ou manuais, sob risco de anular aspectos históricos autênticos e traços estéticos de grande relevância. Contradição flagrante entre as posturas adotadas e 0 que propõe a Carta de Veneza, que postula que a restauração "Tem por objetivo conservar e revelar os valores estéticos e históricos do monumento e fundamenta-se no respeito ao material original e aos documentos autênticos".72

Em meados da década de 1970 é criado o Centro Nacional de Referência Cultural - CNRC, formado por alguns professores da Universidade de Brasília de diferentes áreas e disciplinas acadêmicas, dentre os quais Aloísio Magalhães, diretor do grupo. Este centro formou-se dentro da Universidade e não nos quadros da burocracia estatal, ainda que tenha contado desde 0 princípio com 0 apoio de entidades governamentais, tais como a Caixa Econômica Federal (CEF) e Instituto de Planejamento Econômico e Social (IPEA), e de diferentes Ministérios, a exemplo do Ministério da Indústria e Comércio (MIC), das Relações Exteriores (MRE) e mesmo de Educação e Cultura (MEC). O CNRC tinha como objetivo central "a realização de estudos,

\footnotetext{
70 MAYUMI, Lia. Monumento e autenticidade..., op. cit., pp. 245.

71 Idem, pp. 250.

72 Carta de Veneza - 1964, In: Cartas Patrimoniais..., op. cit., pp. 93.
} 
pesquisas, planos e programas, visando estabelecer um sistema referencial básico, a ser empregado na descrição e na análise da dinâmica cultural brasileira",73 pensando a produção cultural no contexto brasileiro contemporâneo, de maneira articulada à questão do desenvolvimento.

Diferentemente de Rodrigo, seu propósito [de Aloísio Magalhães] não é "civilizar" o Brasil preservando uma "tradição", mas revelar a diversidade da cultura brasileira e assegurar que ela seja levada em conta no processo de desenvolvimento. ${ }^{74}$

Dessa forma, a noção de patrimônio histórico e artístico, presente no ideário patrimonial brasileiro até então, é substituída pela noção de bem cultural, que representaria a ampliação no alcance das práticas patrimoniais implementadas no Brasil, incorporando o que se fazia até aquele momento na nova conceituação. Segundo Joaquim Falcão, a noção de bem cultural trazida por Aloísio Magalhães

[...] se opôs à noção de patrimônio histórico e, ao mesmo tempo, a incorporou. Opôs-se na medida em que a noção de patrimônio foi, historicamente, apropriada e reduzida à noção de preservação do patrimônio de pedra e cal. De preservação arquitetônica dos monumentos da etnia branca e sua elite civil, militar ou eclesiástica. Incorporou-o na media em que patrimônio histórico passou a ser espécie, e bens culturais, gênero. Trata-se portanto de conceito mais abrangente, que incorpora o bem ecológico, a tecnologia, a arte, o fazer e o saber..$^{75}$

Outra noção fundamental do pensamento de Aloísio Magalhães no trato com a questão cultural brasileira refere-se à idéia de continuidade no processo cultural, encarada como arma contra o colonialismo das Nações ricas, a qual garantiria a identidade e a autonomia do país. Tal continuidade não implicava em imobilismo ou estagnação, ao contrário, "comporta modificações e alterações num processo aberto e flexível, de constante realimentação, o que garante a uma cultura sua sobrevivência". ${ }^{6}$ Segundo Aloísio, devido ao fato de o Brasil ser um país jovem e pobre, interessava demonstrar a capacidade de manifestações da cultura popular de gerar valor econômico e contribuir no processo de desenvolvimento brasileiro. Essas práticas tradicionais e ao mesmo tempo cotidianas deveriam garantir a emancipação política, econômica e cultural do país, sob ameaça homogeneizadora das grandes potências imperialistas.

${ }^{73}$ Convênio de Estruturação do CNRC, cláusula primeira, In: Proteção e revitalização..., op. cit., pp. 116.

74 GONÇALVES, José Reginaldo Santos. A Retórica da Perda: os discursos do patrimônio cultural no Brasil. Rio de Janeiro: Ed. UFRJ / IPHAN, 1996, pp. 53.

75 FALCÃO, Joaquim. "A política cultural de Aloísio Magalhães", In: MAGALHÃES, Aloísio. E Triunfo?..., op. cit., pp. 18.

${ }^{76}$ MAGALHÃES, Aloísio. E Triunfo?..., op. cit. pp. 44. 
De 1975 até 1978 o CNRC permanece autônomo em relação à burocracia estatal, através da renovação o Convênio que o constituiu, visando dar prosseguimento aos trabalhos desenvolvidos até então. Entretanto, após quatro anos de atividades, Aloísio Magalhães avalia que

[...] é chegado o momento de constatar que uma ação efetiva dos resultados obtidos através dos indicadores que se tornam conhecidos só pode ser realizada tendo o CNRC uma posição claramente definida dentro do quadro geral do sistema administrativo e dele fazendo parte como instrumento auxiliar válido. ${ }^{77}$

A forma encontrada para oficialização do CNRC dentro da estrutura governamental foi sua incorporação ao IPHAN, o qual, desde março de 1979, contava com o próprio Aloísio Magalhães na direção. Aloísio acreditava na "possibilidade de ampliar e revitalizar" o órgão federal de preservação, propondo não a criação de uma nova instituição, mas a "dinamização de uma já existente, que passaria a cobrir maior espectro de bens culturais". ${ }^{78}$

Ao final do ano de 1979, o presidente João Figueiredo assina o decreto que transforma o IPHAN em Secretaria do Patrimônio Histórico e Artístico Nacional - SPHAN, posteriormente reunida em uma única instituição com o PCH e o CNRC, através da criação da Fundação Nacional Pró-Memória.

Reuniam-se assim, numa só instituição, os recursos e o know-how gerencial do $\mathrm{PCH}$, o prestígio e a competência técnica do IPHAN e a visão moderna e renovadora do CNRC. Foi criada uma nova estrutura: um órgão normativo - a Secretaria do Patrimônio Histórico e Artístico Nacional (SPHAN) e um órgão executivo - a Fundação Nacional PróMemória (FNPM).79

Com a fusão do CNRC e PCH com o IPHAN e a institucionalização da FNPM, Aloísio Magalhães pretendia dar novos contornos à prática patrimonial, dissolvendo a dicotomia erudito/popular instalada no panorama do antigo SPHAN, para 0 qual a cultura popular teria interesse para etnógrafos e folcloristas, sendo a cultura erudita o que se devia preservar como monumento nacional em razão do excepcional valor histórico e artístico (uma interpretação literal do Decreto-lei n. 25). Com a renovação das ações preservacionistas pretendia-se a incorporação de produtos das culturas popular, indígena e afrobrasileira - o chamado patrimônio cultural não-consagrado. Nos mais de 40 anos de atuação do IPHAN, diagnosticou-se uma

\footnotetext{
77 Idem, pp. 57.

78 Idem, pp. 54.

79 FONSECA, Maria Cecília Londres. Op. cit., pp. 154.
} 
[...] hipertrofia dos setores dedicados à conservação e restauração dos monumentos de pedra e cal [...] em detrimento não só da arquitetura popular autóctone, mas também à custa da atrofia dos setores encarregados da preservação do patrimônio arqueológico, do patrimônio natural, dos arquivos históricos e iconográficos, do acervo etnográfico [...]. Diante desse desequilíbrio deformador da fisionomia da instituição, impunha-se a formulação de um conceito mais envolvente de bem cultural, atento para as múltiplas manifestações do fazer do homem brasileiro. ${ }^{80}$

Às transformações conceituais verificadas ao longo dos anos $1960 \mathrm{e}$ 1970 no quadro das políticas de preservação no Brasil em âmbito federal, somam-se aquelas de natureza estrutural, operadas a partir da fusão da SPHAN com a FNPM como sistema integrado. Conforme seus idealizadores, a Secretaria passaria a ser uma estrutura da administração direta e a Pró-Memória seu braço executivo e operacional. Previa-se que a SPHAN concentrasse apenas os cargos diretivos, cabendo à Pró-Memória, os trabalhos de inventário, classificação, conservação, proteção, restauração e revitalização dos bens de valor cultural, através da transferência do quadro profissional anteriormente

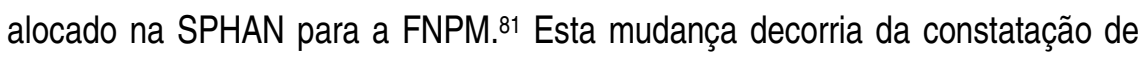
que mesmo com as novas concepções de patrimônio incorporadas ao discurso patrimonial da SPHAN a partir da inclusão do $\mathrm{CNRC}$ e do $\mathrm{PCH}$, a rígida estrutura administrativa do antigo órgão impedia a efetivação de um desempenho renovado.

A falta de flexibilidade não apenas gerava problemas incontornáveis, entre os quais a notória impossibilidade de conseguir verbas extraorçamentárias, como ainda provocava embaraços de ordem operacional, exemplificados na questão da mão-de-obra especializada. [...] no curso de sua experiência o Iphan acumulou um conhecimento técnico respeitável na área de restauração, tendo formado artesãos altamente qualificados. No entanto, esses profissionais acabavam se desligando da instituição [...] apenas porque não era possivel ao Iphan retê-los em seu quadro pessoal. 82

A criação de uma fundação, personalidade jurídica de direito privado, parecia aos técnicos da Secretaria de Modernização e Reforma Administrativa (SEMOR) e a vários especialistas consultados a opção mais adequada para essa dinamização dos instrumentos de preservação no âmbito federal. Como instância privilegiada de poder, a SPHAN forneceria as diretrizes para escolha dos projetos a serem desenvolvidos pela FNPM, bem como, permaneceria

80 Proteção e revitalização... Op. cit., pp. 27.

${ }_{81}$ Conforme Decreto n. 84.396, de 16/01/1980, que aprova o Estatuto da Fundação Nacional Pró-Memória. Ver também: "Sphan/Pró-Memória: a mudança sem perda da identidade", In: Proteção e revitalização... Op. cit., pp. 137-139.

82 Proteção e revitalização... Op. cit., pp. 28. 
responsável pelos processos de tombamento, já que "o poder do tombamento é um poder tão grave, de tamanha relevância, uma interferência tão direta na propriedade privada, que só um elemento diretamente ligado ao governo pode exercer".83

No entanto, a transformação efetiva dos novos conceitos em uma renovada prática institucional não se daria de modo automático ou milagroso. De fato, os antigos funcionários do IPHAN sentiam-se mais ameaçados que estimulados pelos novos ares que sopravam no Patrimônio e o que deveria ser uma fórmula de cooperação entre a nova SPHAN e a Pró-Memória, acabou por se constituir em instâncias não-comunicantes de ação. Tudo isso agravado pela morte prematura do novo líder institucional, Aloísio Magalhães, em junho de 1982.84

Em 1981 é criada na esfera do MEC a Secretaria de Cultura, cuja direção foi atribuída pelo ministro Rubem Ludwig a Aloísio Magalhães, resultando na transformação da SPHAN em Subsecretaria. Se por um lado, a criação da SEC representa uma aparente ampliação do espaço institucional da cultura dentro do governo federal, por outro, pode ser vista como enfraquecimento da recém-criada estrutura organizacional do sistema SPHAN/Pró-Memória. Isto porque a articulação ainda frágil entre as duas instâncias - a do órgão normativo e do órgão executivo - vê-se atropelada pelo distanciamento de Aloísio Magalhães, primeiramente assoberbado com as tarefas de Secretário de Cultura e depois com sua morte. Dessa forma, ocorre a divisão das tarefas diretivas das duas instituições, que passam a estar sob responsabilidade de diferentes dirigentes, acarretando uma superposição de atribuição e não a imaginada ação integrada e organicamente estruturada. ${ }^{85}$

Quando em 1985 é criado o Ministério da Cultura (MinC), a SPHAN volta ao seu estatuto anterior de Secretaria, porém, em 1987, a "restauração do Patrimônio", nas palavras de Angelo Oswaldo de Araújo Santos, ainda se apresenta como desafio futuro:

Como projetar no âmbito da SPHAN/Pró-Memória, o programa amplo que Aloísio Magalhães veio propor? Como operar SPHAN/Pró-Memória no quadro descentralizador do Ministério da Cultura, aberto à emancipação e ao arejamento das áreas de seu envolvimento? Como, enfim, conjugar

\footnotetext{
83 "Sphan/Pró-Memória: a mudança...". Op. cit., pp. 139.

${ }^{84}$ FONSECA, Maria Cecília Londres. Op. cit., pp. 172-174.

85 Idem, pp. 199
} 
a lição de Rodrigo, a lição de Aloísio e a aula magna de Mário, meio século contado?

Aquela revolução no cerne conceitual do Patrimônio permanece no eixo dos programas de hoje. Absorvida, porém, como rotina de trabalho, na amplitude dos objetivos a se atingirem, faltava-Ihe 0 desfecho operacional, que cabe ao Ministério da Cultura implementar, no plano político-administrativo.

A riqueza de conceitos redescobertos por Aloísio Magalhães corresponde a carência de meios para lançá-la nas realidades do País imenso. ${ }^{86}$

A segmentação do trabalho desenvolvido pelos funcionários do "Patrimônio", alocados na SPHAN, e aqueles da "Referência", vinculados à PróMemória, dificilmente foi resolvida, mantendo-se as atuações "tradicionais", isto é, a SPHAN imbuída do objetivo de identificar, tombar e restaurar os monumentos arquitetônicos e a Pró-Memória, dedicada às pesquisas sobre os fazeres e saberes de diferentes regiões do país. Interessante notar que algumas das pesquisas mais importantes levadas a cabo pelos pesquisadores do CNRC (depois FNPM), tal como a da fábrica de vinho de caju na Paraíba, redundaram na abertura de processos de tombamento, demonstrando que, ainda que institucionalmente se operasse com novos conceitos, não haviam sido desenvolvidos novos instrumentos de proteção e acautelamento. De fato, ainda que tenha havido uma ampliação do conceito de patrimônio histórico e artístico para o de bem cultural, ampliação, inclusive, incluída no novo texto constitucional de $1988,{ }^{87}$ tal ampliação tornava-se bastante problemática na prática, posto que não tinham sido desenvolvidas na sociedade brasileira formas alternativas para dar conta da salvaguarda dessa tipologia específica de bens que são os de natureza imaterial. Deve-se destacar também que no Brasil a preservação tem ainda no tombamento sua forma consagrada e consagradora, e este instituto jurídico, de acordo com as determinações legais, não é apropriado às novas categorias de bens imateriais, como ritos e tradições ou mesmo aqueles modos de saber-fazer tradicionais, podendo recair exclusivamente sobre "coisas materiais", sejam bens móveis ou imóveis. ${ }^{88}$

86 SANTOS, Angelo Oswaldo de Araújo. "Restaura-se o Patrimônio", In: Revista do Patrimônio Histórico e Artístico Nacional. Rio de Janeiro: SPHAN / Pró-Memória, n. 22, 1987 , pp. 38.

87 Em seu artigo 126, a Constituição Federal de 1988 registra a expressão "patrimônio cultural", incorporando bens de natureza material e imaterial, "portadores de referência à identidade, à ação, à memória dos diferentes grupos formadores da sociedade brasileira". Cf.: Constituição da República Federativa do Brasil, art. 216, In: Coletânea de leis..., op. cit., pp. 20-21.

${ }^{88}$ Como esclarece Sonia Rabello de Castro, o tombamento, tal como estabelecido no Decreto-lei n. 25, não pode ser aplicado a bens imateriais ou intangíveis, somente sobre coisas materiais, posto que seus efeitos são inócuos para bens de natureza intangível. 
Dentre os exemplares do "patrimônio cultural consagrado" - os bens de pedra e cal - não foi essa ampliação conceitual menos problemática: os técnicos do Patrimônio resistiram em incorporar entre os bens arrolados nos livros de tombo da instituição aqueles que escapassem aos cânones artístico e histórico

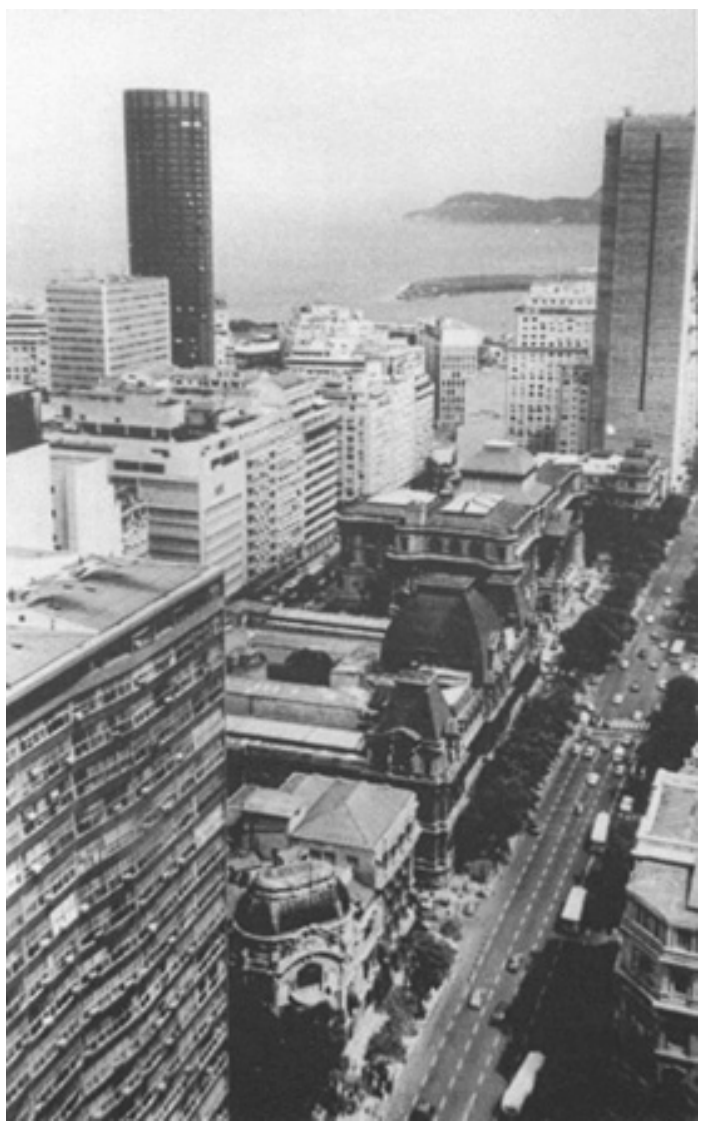

Fig. 20 - Conjunto arquitetônico da Avenida Rio Branco, Rio de Janeiro. Fonte: COSTA, 1999, pp. 299. até então praticados para que se pudesse incluir tipologias, estilos e períodos históricos mais recentes. Nesse sentido, 0 processo de tombamento das edificações da Avenida Rio Branco no Rio de Janeiro é exemplo contundente. ${ }^{89}$

A partir de pedido encaminhado pelo Instituto de Arquitetos do Brasil e pelo Clube de Engenharia solicitava-se 0 tombamento federal dos remanescentes da ocupação da Avenida Central (depois Avenida Rio Branco), considerado testemunho histórico e artístico de um momento específico da história carioca: a renovação urbana perpetrada durante a gestão do prefeito Pereira Passos no início do século XX.

\section{A Divisão de Estudos e Tombamentos (DET)} do IPHAN, no entanto, julgou que as edificações não constituíam um conjunto e, avaliadas individualmente, só foram consideradas passíveis de tombamento aquelas ainda não descaracterizadas: 0 Teatro Municipal e a Escola de Belas Artes (Fig. 20). 0 parecer da DET, de autoria de Lígia Martins Costa, contrariava a opinião de Paulo Santos, membro do Conselho Consultivo do IPHAN e relator do processo, fato que deflagrou uma divisão poucas vezes vista na história da instituição até aquele momento. Em defesa de dona Lígia veio Lucio Costa, que mesmo aposentado, "há 40 anos tem sido e continua a ser nosso maior doutrinador em

Ver: CASTRO, Sonia Rabello de. Op. cit., pp. 69. Francisco Cunha Filho destaca que: "quando se adota este procedimento [o tombamento] o que se quer é uma perenização do aspecto do bem tombado pelo maior tempo possível [...]. Nenhum efeito prático, portanto, existe no ato de tombar uma dança, uma língua ou uma feira de artesanato, pois não é possível - e em muitos casos também não é recomendável - estabelecer controle às influências que sofrem os referidos bens" (CUNHA FILHO, Francisco Humberto. Op. cit., pp. 4).

89 Processo 860-T-72. Cf. FONSECA, Maria Cecília Londres. Op. cit., pp. 218 e ss. 
arquitetura e urbanismo". 90 Este redige 0 artigo "Problema mal posto", no qual combate os principais pontos da argumentação de Paulo Santos a respeito do valor artístico e de conjunto apresentados pelos edifícios da Avenida Central. Fica flagrante nesse episódio o enfrentamento de duas correntes no interior do IPHAN: a manutenção da "coerência" do órgão91 versus a constatação de que cada obra deva ser julgada em função dos dados culturais que a produziu. ${ }^{92}$

Mas, apesar das dificuldades dos funcionários do IPHAN em lidar com as inovações, a incorporação de novos programas à lista do patrimônio nacional fez-se sentir ao longo da década de 1980, exemplificadas pelo tombamento da Coleção de ex-votos do Santuário de Bom Jesus de Matozinhos (Congonhas, $M G$ ), em 1981; do conjunto de residências na Avenida Modelo (Rio de Janeiro, RJ), em 1985; do Terreiro da Casa Branca (Salvador/BA - Fig. 21/22), em 1986; do prédio da Fábrica Santa Amélia, antigo Cotonifício Cândido Ribeiro (São Luís/MA), em 1987; ou do Complexo ferroviário de São João del Rei (São João Del Rei e Tiradentes/MG), em 1989. Foram incorporados aos livros de tombo do Patrimônio Nacional representantes das diversas correntes imigratórias que chegaram ao Brasil, tais como a Casa da Neni, em Antonio Prado/RS (inscrita no Livro de Belas Artes em 1985), imóvel representativo da cultura da imigração italiana; ou do Casarão do Chá, em Mogi das Cruzes/SP, representativo da imigração japonesa (inscrito no Livro de Belas Artes em 1985 e nos Livros Histórico e Arqueológico, Etnográfico e Paisagístico em 1986).93

Interessante destacar, ainda sobre a questão dos tombamentos, um possível indicador de que a ruptura com as antigas práticas preservacionistas do IPHAN durante sua fase moderna não foi total: a campanha liderada por Aloísio Magalhães para a inclusão de Ouro Preto, do centro histórico de Olinda e dos

90 Curiosamente, essa afirmação da importância da figura de Dr. Lucio provém do próprio arquiteto Paulo Santos. Ver: COSTA, Lucio. Op. cit., pp. 279.

${ }^{91} \mathrm{Cf}$. artigo "Problema mal posto", de Lucio Costa. COSTA, Lucio. Op. cit., pp. 273. Lucio Costa faz afirmação semelhante quando se considerou o tombamento do Solar Monjope, também no Rio de Janeiro: "O chamado 'Solar Monjope' é um falso testemunho, exemplo de como uma casa brasileira nunca foi. A tarefa inicial do antigo Serviço do Patrimônio Histórico e Artístico Nacional consistiu em desfazer o equívoco que levou a essa pseudoreconstituição. Deve-se considerar, pois, contraditório, para não dizer chocante, que se insinue agora a conveniência do tombamento dessa elaborada cenografia como "documento histórico"." (Ver: COSTA, Lucio. Op. cit., pp. 283. Grifos do autor.) 92 Parecer de Paulo Santos. COSTA, Lucio. Op. cit., pp. 279.

${ }^{93}$ Todas as referências aos tombamentos citados neste parágrafo foram extraídas da Base de dados digital do Arquivo Noronha Santos (http://www.iphan.gov.br/ans/inicial.htm), dentre os 97 bens tombados no período de 1980 a 1989. 
remanescentes de São Miguel das Missões na lista do Patrimônio Mundial da UNESCO, corroborando, dessa forma, com os primeiros atos do antigo SPHAN. ${ }^{94}$ Para Aloísio Magalhães não era necessário desmerecer o trabalho anteriormente feito para privilegiar o "patrimônio cultural não-consagrado", era

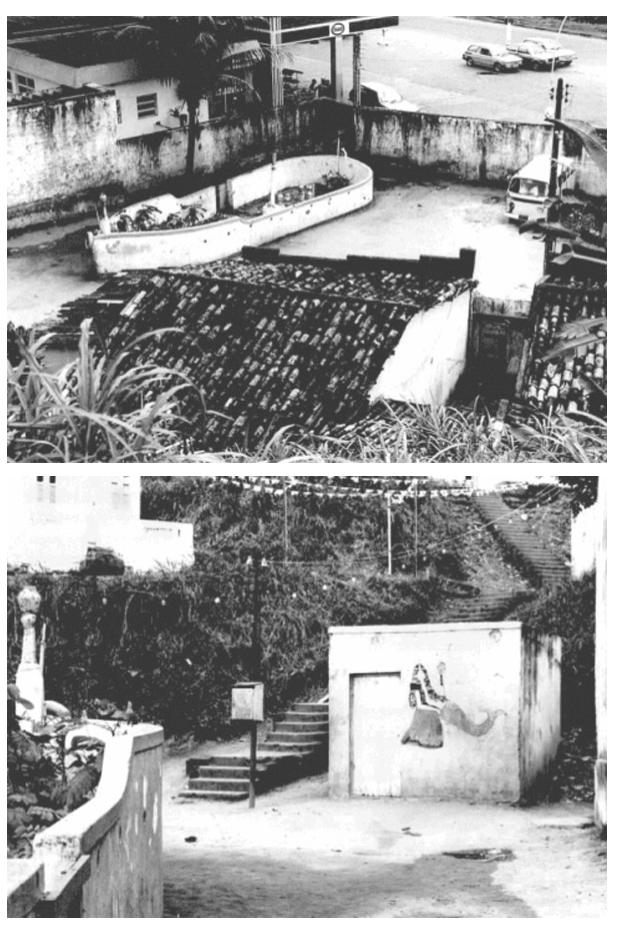

Fig. 21/22 - Terreiro da Casa Branca, Salvador, tombado em 1982. Fonte: Revista do Patrimônio, n. 24, pp. 161. possivel a conjugação das práticas preservacionistas que exaltavam os bens de excepcional valor artístico e histórico com a valorização e proteção das manifestações da cultura popular. Esta era a fórmula de cooperação e a ação organicamente estruturada buscada pelo líder institucional, que, infelizmente, foi malograda pelos acontecimentos e por sua precoce ausência.

Outra faceta da atuação do órgão federal de salvaguarda do patrimônio cultural brasileiro no período em questão que merece ser avaliada refere-se às obras de restauração. Em que medida a aceitação de diferentes épocas e tipologias de bens imóveis no rol dos monumentos nacionais, juntamente com informações técnicometodológicas mais atualizadas, redundou em posturas mais conservativas, por oposição às intervenções "radicais" à moda de Viollet-le-Duc até então implementadas?

Nesse sentido, serão analisadas aqui duas intervenções: uma em um núcleo urbano histórico recuperado no âmbito do $\mathrm{PCH}-0$ centro histórico de Olinda -, entre os anos 1981 e 1985, e outra, a restauração de um monumento isolado - o Paço Imperial - no Rio de Janeiro, ocorrida entre 1982 e 1984,

\footnotetext{
${ }^{94}$ De fato esses bens foram incluídos na Lista do Patrimônio Mundial: Ouro Preto foi inscrita em 1980 por representar uma obra-prima do gênio criativo humano (critério i) e por ser testemunho excepcional de uma tradição cultural ou civilização que esteja viva ou que tenha desaparecido (critério iii); o centro histórico de Olinda foi incluído na lista em 1982 por exibir um importante intercâmbio de valores humanos, durante um período de tempo ou dentro de um espaço cultural do mundo, sobre a evolução da arquitetura e da tecnologia, das artes monumentais, do planejamento urbano ou paisagismo (critério ii) e por ser um exemplo excepcional de um tipo de construção, conjunto arquitetônico ou tecnológico ou de paisagem que ilustra um estágio significativo na história da humanidade (critério iv); e São Miguel das Missões foi inscrito em 1983, por ser um exemplo excepcional de um tipo de construção, conjunto arquitetônico ou tecnológico ou de paisagem que ilustra um estágio significativo na história da humanidade (critério iv). Ver: http://whc.unesco.org/en/statesparties/br. Acesso: 13 jan. 2010, 10:47.
} 
ambas experiências relatadas na Revista do Patrimônio Histórico e Artístico Nacional, tradicionalmente canal de divulgação das ações institucionais. ${ }^{95}$

A arquiteta Vera Bosi narra a experiência piloto de recuperação e revitalização do centro histórico de Olinda, que deveria servir de modelo para intervenções posteriores. Surgida de um acordo interministerial firmado entre 0 Ministério da Cultura (MinC), através da SPHAN/FNPM, e o Ministério do Interior (MINTER), através do Banco Nacional de Habitação (BNH), esta iniciativa tinha

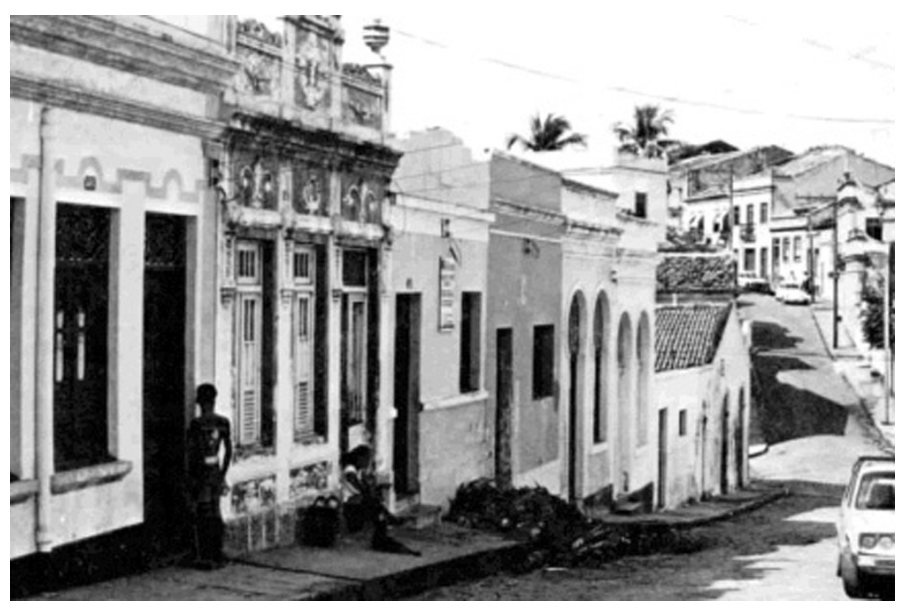

Fig. 23 - Projeto piloto na Ladeira da Misericórdia, Olinda. Fonte: Revista do Patrimônio, n. 21, pp. 137. como objetivo a recuperação de unidades habitacionais degradadas localizadas em áreas de interesse histórico-arquitetônico, com vistas à diminuição do déficit habitacional aliada à preservação patrimonial (Fig. 23). A premissa básica desta ação experimental era a participação da comunidade em todas as etapas do projeto, desde seu planejamento e estabelecimento de prioridades até sua execução. ${ }^{96}$ Além do financiamento do

BNH e da supervisão da SPHAN, entidades locais também foram mobilizadas para implantação do projeto piloto: Fundação Centro de Preservação dos Sítios Históricos de Olinda (FCPSHO) e Prefeitura Municipal, a qual já contava com um aparato de preservação do patrimônio organizado.97

O privilégio dado ao chamado "patrimônio habitacional" no âmbito do programa de recuperação se dava em função de uma nova percepção, mais complexa, de monumento histórico, que passa a ser encarado em termos mais amplos do que tinha sido considerado até aquele momento. Ainda assim, as ações implementadas no projeto piloto não deveriam se restringir apenas às unidades habitacionais, posto que, desse modo, estariam reproduzindo "ações

95 Trata-se dos números 20 e 21 da Revista. Sobre o Paço Imperial: Revista do Patrimônio Histórico e Artístico Nacional. Rio de Janeiro: SPHAN / Pró-Memória, n. 20, 1984, pp. 112-165. Sobre a recuperação do núcleo histórico de Olinda: Revista do Patrimônio Histórico e Artístico Nacional. Rio de Janeiro: SPHAN / Pró-Memória, n. 21, 1986, pp. 134-145; e também: Revista do Patrimônio Histórico e Artístico Nacional. Rio de Janeiro: SPHAN / Pró-Memória, n. 22, 1987, pp. 138-144.

96 BOSI, Vera. "Núcleos históricos: recuperação e revitalização; a experiência de Olinda", In: Revista do Patrimônio..., n. 21, op. cit., pp. 134.

97 Idem, pp. 139. 
pontuais, tão excludentes quanto as que têm sido até então praticadas na trajetória do Patrimônio Histórico, quando contempla o monumento isolado".98 Estava se desenvolvendo, doravante, uma visão mais orgânica dos núcleos históricos, que não deveriam mais ser abordados pelo viés exclusivo de seus valores estético-arquitetônicos, mas através do entendimento de que

Olinda, com seus quatrocentos anos, não é uma cidade morta. Ao contrário, é uma cidade viva, é uma cidade em que você sente uma enorme vitalidade quando se aproxima dela. É uma cidade que tem criança na rua. [...] Como guardar, preservar e não cercear a dinâmica de vida própria de uma comunidade nova? Este é um desafio imenso, é uma coisa que deve fazer parte das nossas discussões: encontrar mecanismos que permitam essa adequação entre a postura de preservar e a postura de mudar, crescer. $^{99}$

A busca por equilibrar as necessidades de crescimento e transformação em harmonia com a preservação patrimonial estava no centro do projeto piloto de Olinda, porém, esta nova postura encontrou resistência dos antigos técnicos do Patrimônio, tradicionalmente comprometidos com a restauração de monumentos isolados:

[...] as equipes técnicas, especialmente treinadas para a prática da restauração, não estavam preparadas para se defrontar com o volume e a complexidade das atividades que deveriam promover. Não se pretendia somente a simples restauração dos bens, mas se buscava, a partir da preservação e revitalização dos conjuntos históricos, a garantia de participação e manutenção da comunidade neles residente, intensificando seu uso pela comunidade em geral, numa conjugação de esforços de todos os agentes dos diversos setores da administração pública, com o objetivo único de preservar a memória local e nacional.100

A restauração não era concebida como fim em si mesmo, mas como um dos elementos necessários à melhoria da qualidade de vida da população que habitava naquela região, carente de recursos de toda natureza, mas desejosa de preservar suas raízes. ${ }^{101} \mathrm{~A}$ postura adotada estava em consonância com as propostas nas Recomendações de Nairóbi (1976), produto da 19ª Conferência Geral da Unesco, a qual postula que:

Cada conjunto histórico ou tradicional e sua ambiência deveria ser considerado em sua globalidade, como um todo coerente, cujo equilíbrio e caráter específico dependem da síntese dos elementos que 0 compõem e que compreendem tanto as atividades humanas como as construções, a estrutura espacial e as zonas circundantes. Dessa maneira, todos os elementos válidos, incluídas as atividades humanas,

\footnotetext{
98 Idem, pp. 135.

99 MAGALHÃES, Aloísio. E Triunfo?..., op. cit. pp. 86.

100 BOSI, Vera. "Núcleos históricos...", op. cit., pp. 138.

101 Idem, pp. 141.
} 
desde as mais modestas, têm, em relação ao conjunto, uma significação que é preciso respeitar. ${ }^{102}$

Porém, apesar do sucesso desta iniciativa, confirmado pela adesão dos moradores e a restauração de várias unidades habitacionais, o projeto piloto se encerrou em 1985, permanecendo como experiência excepcional, na medida em que novos rumos políticos na administração federal não transformaram aquele processo provisório instituído em Olinda em uma efetiva política pública na área da cultura, como conclui Vera Bosi: "Sem o necessário respaldo político e financeiro, num quadro transitório de mudanças, principalmente na burocracia estatal, se tornou difícil a ampliação e a consolidação do processo". ${ }^{103}$

O outro exemplo a ser relatado é o da restauração do Paço Imperial, edificação localizada na Praça XV de Novembro, centro da cidade do Rio de Janeiro, inscrita em 1938 tanto no Livro de Tombo Histórico quanto no das Belas Artes, ${ }^{104}$ e que tem um caráter bastante importante dentre as ações realizadas pelo IPHAN na década de 1980 (Fig. 24).

Chefiado pelo arquiteto Glauco Campello, o projeto de restauro do Paço Imperial trazia problemas bastante complexos, tendo em vista a seqüência de reformas e transformações decorrente dos diferentes usos atribuídos ao edifício ao longo de seus 240 anos de história. ${ }^{105}$ Segundo Glauco Campello, "O que chegou até nós, uma construção mascarada por fora e semidestruída por dentro, estava praticamente abandonado à espera de nova utilização".106 Ainda conforme Campello, diferentemente das tantas intervenções sofridas pelo Paço que tinham como objetivo dar-Ihe uma nova figura, condizente com novas funções, a restauração visava

[...] a reabilitação ou revalorização das marcas deixadas pelas diferentes fases históricas e pelas sucessivas intervenções. Elas serão, tanto quanto possivel, restabelecidas em um único organismo plurivalente e

\footnotetext{
102 Recomendação de Nairóbi - 1976, In: Cartas Patrimoniais..., op. cit., pp. 220.

$103 \mathrm{BOSI}$, Vera. "Participação e pesquisa na preservação do patrimônio cultural", In: Revista do Patrimônio Histórico e Artístico Nacional. Rio de Janeiro: SPHAN / PróMemória, n. 22, 1987, pp. 139.

104 Processo 0159-T-38. Cf. base de dados do Arquivo Noronha Santos na internet, disponivel em: http://www.iphan.gov.br/ans/inicial.htm.

105 CAMPELLO, Glauco. "A restauração do Paço: revendo 240 anos de transformações", In: Revista do Patrimônio..., n. 20, op. cit., pp. 139. Este número da Revista do Patrimônio também indica a participação de Cyro Corrêa de Lyra, José de Souza Reis e Gilberto Ferrez na equipe de projeto.

106 Idem, ibidem.
} 
RESTAURAÇÃO: diálogos entre teoria e prática no brasil nas experiências do iphan 3_restauração na fase moderna do iphan

complexo, apto a reunir aspectos diversificados e até conflitantes sob a unidade de valores arquitetônicos e históricos preponderantes. ${ }^{107}$

Antevia-se, assim, a disposição por parte dos coordenadores do projeto de restauro de agir em conformidade com aqueles pressupostos oferecidos pela Carta de Veneza, que indicavam o respeito às várias estratificações históricas do monumento, dado que a unidade estilística não era a meta da restauração. ${ }^{108}$ № entanto, ao longo das pesquisas históricas e principalmente, no contato direto com o bem cultural, as intenções inicias parecem ter sido alteradas, assumindo-

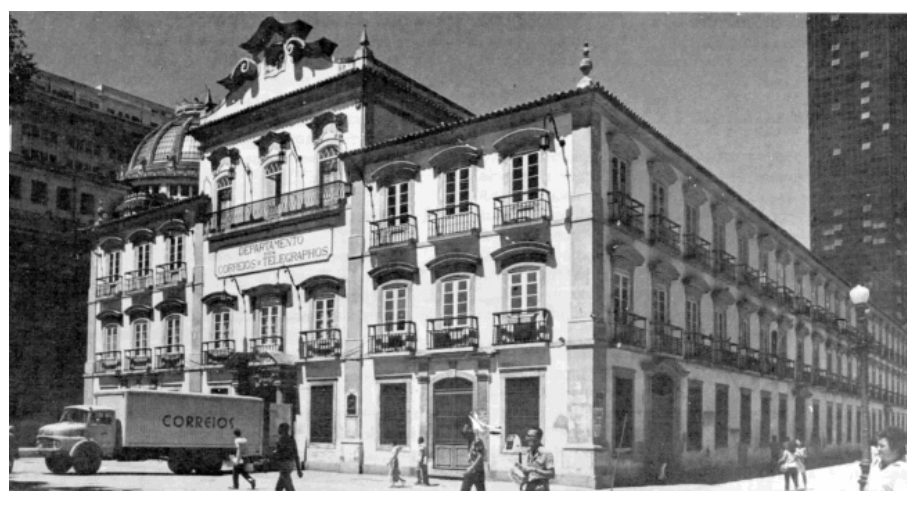

Fig. 24 - Paço Imperial, Rio de Janeiro, década de 1980, antes das obras de restauro. Fonte: Revista do Patrimônio, n. 20, pp. 141. se que "à medida que a demolição dos acréscimos ia revelando aspectos surpreendentes de sua dignidade antiga [...] Tornara-se então irresistível a atração pela integridade de sua imagem barroca representada nas gravuras antigas" (Fig. 25). ${ }^{109}$ Ora, se havia realmente, como afirma Campello, o interesse na manutenção e conciliação das "marcas deixadas no

edifício pelas diferentes fases históricas e pelas sucessivas intervenções", porque a "demolição dos acréscimos"? Cyro Corrêa Lyra, outro participante da equipe de projeto, afirma que:

Os trabalhos preliminares de "limpeza", compreendendo a remoção de materiais em mau estado, a realização de prospecções nas paredes, pisos e tetos, bem como a análise da documentação iconográfica puseram em xeque a tese inicial de uma simples conservação. [...] chegou-se à conclusão de que, sob a "vestimenta" neocolonial de 29 , sobrevivia, ainda, totalmente camuflada, uma arquitetura monumental de maior interesse cultural. [...] A par de seu significado histórico, o antigo Palácio, que as reformas do século XX tinham ocultado, poderia ocupar, depois de "revelado", especial lugar no acervo da arquitetura barroca luso-brasileira, representada quase exclusivamente pela arte religiosa. ${ }^{110}$

Os "trabalhos preliminares de limpeza" sugerem a manutenção de uma fórmula de aproximação com o bem arquitetônico consagrada em diversas

\footnotetext{
107 Idem, ibidem.

108 A Carta de Veneza indica que "As contribuições válidas de todas as épocas para a edificação do monumento devem ser respeitadas, visto que a unidade de estilo não é a finalidade a alcançar no curso de uma restauração" (Carta de Veneza - 1964, In: Cartas Patrimoniais, op. cit., pp. 93).

109 CAMPELLO, Glauco. "A restauração do Paço...", op. cit., pp. 142.

110 LYRA, Cyro Corrêa. "O novo Paço: uma obra para debates", In: Revista do Patrimônio..., n. 20, op. cit., pp. 153.
} 
restaurações empreendidas pelo antigo SPHAN, nas quais as prospecções eram feitas através da remoção total das camadas externas de revestimento dos edifícios. ${ }^{111}$ Demonstra também que a intenção da restauração migra do respeito ao monumento enquanto documento histórico para uma apreciação exclusivamente estética, na qual as interferências do início do século XX (a reforma neo-colonial) apresentam-se como ruído descaracterizador da integridade original. Novamente os procedimentos se aproximam mais do antigo modus operandi dos arquitetos e técnicos da fase heróica do que dos preceitos oferecidos pela moderna teoria da restauração.

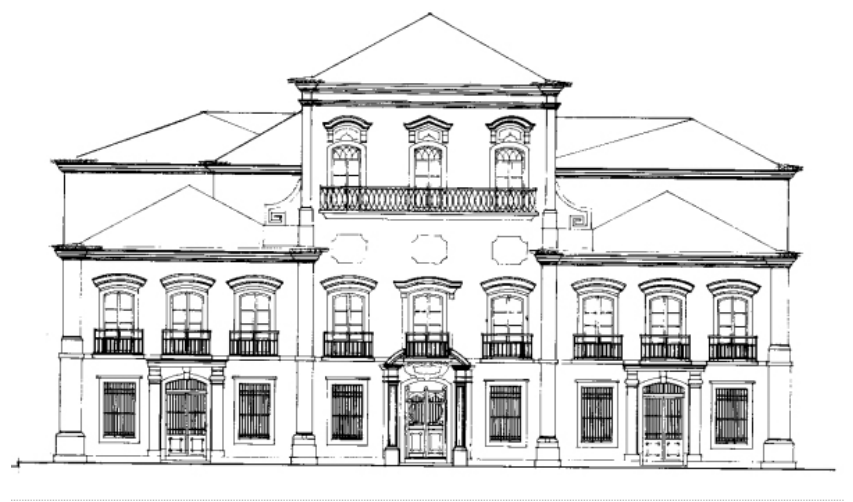

Fig. 25 - Paço Imperial, projeto de restauro. Fonte: Revista do Patrimônio, n. 20, pp. 149.

No entanto, existem algumas diferenças que devem ser salientadas entre a intervenção no Paço Imperial e as restaurações "canônicas" da fase heróica do SPHAN. O processo de intervenção é mais cuidadoso no que tange às etapas de levantamento preliminar da história e iconografia referentes ao edifício, que neste caso antecede à intervenção propriamente dita, procedimento oposto ao da fase heróica, na qual as diferentes etapas da restauração muitas vezes eram concomitantes. ${ }^{112}$ Além disso, não houve uma determinação rígida de retorno ao estilo barroco, admitindo-se a manutenção de certas estruturas de períodos posteriores e optando pela não-reconstituição de elementos arquitetônicos dos quais não se encontravam vestígios na própria construção, ainda que a iconografia fornecesse elementos seguros para tal ação. Dessa forma, nota-se a adoção de um partido de intervenção híbrido, que ora privilegia o critério estético e a coerência com a edificação barroca que se deseja retomar, ora mantém certas estruturas, mesmo que de comprovada fatura posterior ao período que se deseja consagrar com a restauração, promovendo a manutenção de diferentes estratificações históricas. ${ }^{113}$

A restauração do Paço Imperial parece, portanto, ser um exemplo bastante forte de que "Não é fácil [...] traduzir os novos critérios de seleção em

\footnotetext{
${ }^{111}$ Como demonstram as análises de: GONÇALVES, Cristiane Souza. Op. cit., pp. 77. 112 Idem, pp. 72.

113 LYRA, Cyro Corrêa. Op. cit., pp. 154. Ver também: MAYUMI, Lia. Monumento e autenticidade..., op. cit., pp. 115-116.
} 
critérios de intervenção. Na realidade, essa transposição não chegou a se operar completamente nem a se formar como norma geral". ${ }^{114}$

Assim, atravessa-se a década de 1980 e chega-se a década de 1990 não propriamente com uma redefinição teórico-conceitual que redundasse em novos métodos de intervenção, mas com uma confusão de princípios e conceitos contraditórios, problema que se torna ainda mais agudo tendo em vista a ampliação do que se considera patrimônio e de seu papel na sociedade contemporânean

114 SANT'ANNA, Márcia. Da cidade-monumento..., Op. cit., pp. 216. 


\title{
- CAPÍTULO 4 - RESTAURAÇÃO NO IPHAN DE HOJE
}

\begin{abstract}
Trata-se, hoje, de procurar politizar a política federal de preservação no Brasil, o que não significa reduzi-la a uma prática ideológica, seja a serviço do Estado ou das classes que o ocupam, seja dos excluídos até hoje dos benefícios dessa política. Politizar no sentido de ter como objetivo que esses bens sejam apropriados simbolicamente pelos diferentes grupos sociais que compõem a sociedade brasileira. Ou seja, tirá-los da situação de "pesados e mudos" [...] e fazê-los circular no espaço público, enquanto referências de identidades coletivas e enquanto conteúdos do imaginário social. Maria Cecília Londres Fonseca [O Patrimônio em processo, 1997]
\end{abstract}

A década de 1990 marca uma nova inflexão nas políticas preservacionistas brasileiras em âmbito federal. Se a abertura política e a redemocratização do país nos anos 1980 trouxeram efetivas conquistas no sentido de uma maior participação da população nos mecanismos de proteção ao patrimônio cultural, tais conquistas não chegaram a se consolidar de fato, na medida em que a área da cultura (historicamente relegada a segundo plano nas políticas públicas) sofre duro golpe com a extinção, já em 1990, do Ministério da Cultura - MinC, substituído pela Secretaria de Cultura, organização diretamente ligada à Presidência da República. Neste mesmo ano a SPHAN, juntamente com seu Conselho Consultivo, e a FNPM são também extintas e é criado o Instituto Brasileiro do Patrimônio Cultural - IBPC, sob presidência de Lélia Coelho Frota. A extinção do Conselho Consultivo da SPHAN leva à paralisação dos trabalhos, que só são retomados em 1992, quando o Conselho é reconduzido às suas funções. Também em 1992 a Secretaria de Cultura da Presidência da República é extinta e o Ministério da Cultura é recriado. Em 1994 o IBPC volta a se denominar IPHAN, mas seu papel de protagonista nas políticas de preservação brasileira não será facilmente recuperado, como se verá adiante.

Ainda são poucos os estudos produzidos e publicados referente às políticas de preservação dos anos 1990 no Brasil. Mas uma análise mais ampla das políticas culturais de modo geral pode dar algumas indicações sugestivas sobre o tema.

Como mencionado anteriormente, em seu artigo 126, a Constituição Federal de 1988 amplia o leque de bens cuja salvaguarda deve ser garantida 
pelo Estado, afirmando que "constituem patrimônio cultural brasileiro os bens de natureza material e imaterial, tomados individualmente ou em conjunto, portadores de referência à identidade, à ação, à memória dos diferentes grupos formadores da sociedade brasileira". ${ }^{1}$ O eixo do discurso migra dos bens móveis e imóveis, que se constituiriam em patrimônio histórico e artístico nacional, conforme previsto no Decreto-lei n. 25, para uma noção de patrimônio bastante ampliada, abarcando bens de natureza material e imaterial, aos quais a sociedade atribui valor cultural.

Igualmente já foi dito que tal ampliação de significados nem sempre foi capaz de se traduzir numa atuação prática renovada, ao menos nos anos imediatos à promulgação da nova Carta Constitucional. Ainda assim, segundo muitos autores que estudam as políticas culturais desse período, ${ }^{2}$ recupera-se com o novo texto legal o ideário presente no anteprojeto de criação do SPAN, elaborado por Mário de Andrade em 1936, dando um caráter antropológico às práticas preservacionistas brasileiras, que acompanham as discussões internacionais sobre o tema.

Mas uma simples crítica à idéia de patrimônio que vigia até aquele momento como restritiva ou elitista redundaria num anacronismo, pois o fato de dar início à construção do corpus patrimonial nacional a partir de objetos materiais, aos quais era atribuído valor histórico ou artístico, não foi uma prática exclusiva do Brasil, ao contrário,

As noções de autenticidade e permanência fundam a prática de preservação ocidental [das quais o Brasil é tributário] e orientam toda a sua lógica, conduzindo à criação de instrumentos voltados para a proteção, guarda e conservação dos bens patrimoniais, pelo tempo mais longo e da forma mais íntegra possiveis. [...] Essa prática e esse padrão baseiam-se, justamente, na permanência da forma e da matéria do bem

\footnotetext{
${ }^{1}$ Constituição da República Federativa do Brasil, art. 216, In: Coletânea de leis..., op. cit., pp. 20-21.

2 Essa idéia de uma "volta" aos conceitos de Mário de Andrade a respeito do que seria patrimônio cultural brasileiro é recorrente, a título de exemplo pode-se citar aqui: OLIVEIRA, Almir Félix Batista de. "O IPHAN e o seu papel na construção/ampliação do conceito de patrimônio histórico/cultural no Brasil", In: Cadernos do CEOM - Bens culturais e ambientais, ano 21, n. 29, pp. 29; FONSECA, Maria Cecília Londres. "Para além da pedra e cal: por uma concepção ampla de patrimônio cultural", In: ABREU, Regina \& CHAGAS, Mário (orgs). Memória e patrimônio: ensaios contemporâneos. Rio de Janeiro: Lamparina, $2^{2}$ ed., 2009, pp. 63; CASTRIOTA, Leonardo Barci. Patrimônio cultural: conceitos, políticas, instrumentos. São Paulo: Annablume, Belo Horizonte: IEDS, 2009, pp. 210-211.
} 
que fixam os valores nele investidos e, simultaneamente, permitem aferir sua autenticidade. ${ }^{3}$

Somente a partir dos anos 1960 é que a cultura passa a ter novos contornos e adjetivos, deixando de identificar-se com erudição e saber especializado, tornando-se cultura popular, cultura tradicional ou cultura de massa. As culturas nacionais deixam de ser vistas como um unicum, passando a ser encaradas como diversas e múltiplas, como são diversos e múltiplos os diferentes grupos que compõem uma Nação. ${ }^{4} \mathrm{O}$ reconhecimento dessa diversidade passa a ser reivindicado através da "oficialização" dessas diferentes e específicas memórias, colocando em crise a representatividade dos monumentos nacionais tal como concebido anteriormente como memória de todos. Ademais, a adesão de países extra-europeus à Convenção do Patrimônio Mundial, instituída pela UNESCO em 1972, forçou a uma revisão nos critérios do que seria "patrimônio cultural e natural de valor universal excepcional", conforme estipulado no texto da Convenção. ${ }^{5}$

Fenômenos como a globalização e a mundialização, dos quais decorrem a massificação e 0 achatamento das culturas locais, passam a ser uma preocupação recorrente a partir de finais dos anos 1970 em diversos países e junto às organizações internacionais, tais como a UNESCO. Este fato fica explícito na Recomendação de Nairóbi, de 1976, que alerta para os "perigos da uniformização e da despersonalização que se manifestam constantemente em nossa época". ${ }^{6}$ Diante de tais perigos, ao final dos anos 1980, a UNESCO estabeleceu as Recomendações sobre a salvaguarda da cultura tradicional e popular, na qual reconhece a "extrema fragilidade de certas formas da cultura" $\mathrm{e}$ coloca como obrigação dos Estados o estabelecimento de ações de identificação, conservação e difusão da cultura tradicional e popular. ${ }^{7}$ Ao aprovar este documento em sua Conferência Geral, a UNESCO deu ensejo à disposição

\footnotetext{
${ }^{3}$ SANT'ANNA, Marcia. "A face imaterial do patrimônio cultural: os novos instrumentos de reconhecimento e valorização", In: ABREU, Regina \& CHAGAS, Mário (orgs). Op. cit., pp. 51.

4 Para este tema remete-se ao primeiro capítulo da dissertação de mestrado: CUNHA, Claudia dos Reis. O patrimônio cultural da cidade de Sorocaba: análise de uma trajetória. São Paulo: FAU-USP, 2005, pp. 17-18.

5 Ver: Convenção sobre a salvaguarda do patrimônio mundial, cultural e natural (1972), In: Cartas Patrimoniais, op. cit., pp. 178.

${ }^{6}$ Conforme $\S 3^{\circ}$ dos Princípios Gerais. Ver: Recomendação de Nairóbi - Recomendação relativa à salvaguarda dos conjuntos históricos e sua função na vida contemporânea (1976), In: Cartas Patrimoniais, op. cit., pp. 217.

${ }^{7}$ Recomendação sobre a salvaguarda da cultura tradicional e popular (1989), In: Cartas Patrimoniais, op. cit., pp. 293-301.
} 
em diversos Estados de novas formas de preservação e acautelamento dos bens culturais, antes restritos quase que exclusivamente ao instituto do tombamento como já se colocou anteriormente - inadequado aos bens de natureza imaterial ou intangível.

A ampliação da noção de patrimônio cultural é, portanto, mais um dos efeitos da globalização, na medida em que ter aspectos de sua cultura, até então considerada por olhares externos como tosca, primitiva ou exótica, reconhecidos como patrimônio mundial contribui para inserir um país ou um grupo social na comunidade internacional, com benefícios não só políticos, mas também econômicos. ${ }^{8}$

Em consonância com os debates internacionais e retomando as noções amplas de arte e cultura, elaboradas por Mário de Andrade ou ainda durante a experiência do CNRC de Aloísio Magalhães, no ano de 1997, em comemoração aos 60 anos de criação do IPHAN, foi organizado em Fortaleza o seminário "Patrimônio Imaterial: estratégias e formas de proteção", que tinha como objetivo discutir e dar subsídios para criação de instrumentos de tutela adequados à proteção dos bens de natureza imaterial. Este seminário contou com a participação de representantes de diversas entidades públicas e privadas, da UNESCO e da sociedade civil e deu origem à Carta de Fortaleza, na qual fica recomendada "que seja criado um grupo de trabalho no Ministério da Cultura, sob coordenação do IPHAN, [...] com o objetivo de desenvolver os estudos necessários para propor a edição de instrumento legal, dispondo sobre a criação do instituto jurídico denominado 'registro', voltado especialmente para a preservação dos bens culturais de natureza imaterial". 9

Esse novo instituto jurídico foi criado através do Decreto n. 3.551, de 04 de agosto de 2000, por meio do qual o Brasil dá início efetivo ao seu Programa Nacional do Patrimônio Imaterial, implementando, dessa maneira, uma série de políticas públicas que tornam operativo o texto constitucional de 1988, o qual determina em seu artigo 126, § 1ำ que "O Poder Público, com a colaboração da comunidade, promoverá e protegerá o patrimônio cultural brasileiro, por meio de inventários, registros, vigilância, tombamento e desapropriação, e de outras formas de acautelamento e preservação". ${ }^{10}$ O Decreto 3.551/2000 institui 0

\footnotetext{
${ }^{8}$ FONSECA, Maria Cecília Londres. "Para além da pedra e cal...", op. cit., pp. $72-73$.

${ }^{9}$ Carta de Fortaleza (1997), In: Cartas Patrimoniais, op. cit., pp. 364.

${ }^{10}$ Constituição da República Federativa do Brasil, art. 216, § 1ํ, In: Coletânea de leis..., op. cit., pp. 20.
} 
Registro de Bens Culturais de Natureza Imaterial, ${ }^{11}$ que, diferentemente do tombamento, não tem como finalidade a conservação física de um objeto, mas o reconhecimento e a valorização das diversas formas de manifestação cultural que constituem o patrimônio cultural brasileiro, tais como ritos, modos de fazer (Fig. 26), produtos típicos, cânticos, ou ainda mercados, feiras, santuários, praças e demais espaços onde se concentram e reproduzem práticas culturais coletivas.

É fora de questão que a criação do Programa Nacional do Patrimônio Imaterial representa um grande avanço nas práticas de preservação do patrimônio brasileiro. Igualmente é inquestionável que o tombamento de bens de

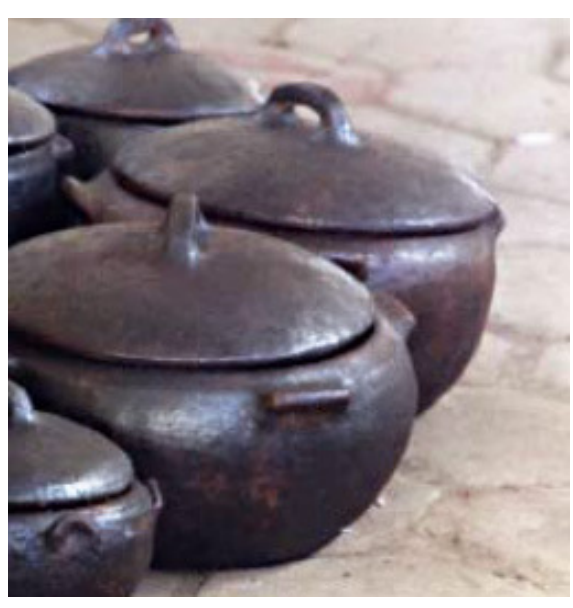

Fig. 26 - Panelas feitas em Goiabeiras/ES. Fonte: Dossiê IPHAN, 2006, pp. 43 natureza intangível é absolutamente inócuo, ${ }^{12}$ sendo assim necessária a introdução de novos instrumentos legais de tutela e salvaguarda. Portanto, sob esse aspecto, de fato o Brasil encontra-se na vanguarda das discussões internacionais e os conceitos de patrimônio e memória adotados pelo Estado representam um enorme ganho para a cultura nacional. Porém, no que concerne aos bens materiais e, especificamente aos edifícios e às áreas urbanas (foco principal deste trabalho), tais avanços parecem ser bastante mais tímidos. Ainda que muitos reconheçam o mérito das ações de preservação levadas a cabo pelo IPHAN em suas primeiras décadas de existência, são também muitos os que ainda defendem que o produto dessas ações foi a consagração de uma memória das elites brancas e católicas - preservou-se a história dos vencedores em detrimento daquela das classes menos abastadas ou das minorias. Mas esta não seria também uma leitura "tradicionalista"? Não seria possível re-pensar os valores de que esses bens são portadores? Além de exemplificar a forma de morar da elite brasileira, através da tipologia arquitetônica e dos materiais

11 São quatro os Livros de Registro criados até o momento: dos Saberes, das Celebrações, das Formas de Expressão e dos Lugares. Porém, podem ser criados outros livros para registrar bens que não se enquadrem em nenhuma das categorias já estabelecidas. Cf.: Decreto n. 3.551, de 04 de agosto de 2000, Art. 1ํㅡ $\S 1^{\circ}=$ e $3^{\circ}$, In: Coletânea de leis..., op. cit., pp. 129-130.

12 Como bem exemplifica o caso do tombamento da Fábrica de Vinho de Caju Tito Silva, em João Pessoa/PB (Processo: 1054-T-82). Fruto do trabalho de inventário e pesquisa do CNRC, a fábrica foi inscrita no Livro Histórico do IPHAN em 1984, porém, aquilo que se desejava preservar - a forma tradicional de produção desse tipo de vinho - não ficou garantida pelo tombamento, dado que no final dos anos 1980 as atividades da fábrica são encerradas e seu patrimônio leiloado para pagamento de dívidas. Como já se disse anteriormente, o tombamento só pode ter eficácia se recair sobre coisas materiais. 
construtivos, os solares e casas-grandes não são também a materialização da sabedoria construtiva dos escravos, na medida em que eram eles os responsáveis diretos pela edificação dos prédios? Novas formas de olhar para 0 "velho" patrimônio gerariam novos e ricos significados que certamente 0 aproximaria das comunidades. Lembrando que nenhum bem traz em si um valor pré-determinado, são sempre as pessoas que atribuem tal valor ao objeto, que pode significar/representar coisas diferentes para distintos grupos: para uns 0 valor de um determinado bem cultural pode ser artístico, para outros, ao contrário, histórico, para outros ainda, simbólico, ou então técnico, social, afetivo, etc. $O$ mesmo bem pode ser lido de variadas maneiras e ser representativo de distintos e múltiplos valores.

Outro grave problema no trato com essas questões se refere à tendência de cindir completamente material de imaterial nas práticas de preservação. Material e imaterial são (ou deveriam ser) dimensões solidárias no campo preservacionista. O patrimônio imaterial precisa de seus suportes materiais para sobreviver, embora sua sobrevivência não seja garantida assegurando unicamente a sobrevivência do suporte material. De outra parte, existe um "substrato imaterial subjacente"13 em qualquer bem material, sem 0 qual sua preservação perde o sentido, tornando-se absolutamente vazia.

Ainda com relação aos bens imóveis, aos bens de pedra e cal,,$^{14}$ apesar da sensação de que tudo já foi dito e discutido e, portanto, não há mais nada de novo ou de necessário para se debater, muitas questões ficaram em suspenso, seja no contexto internacional, seja no ambiente brasileiro. Mesmo que os meios para a preservação tenham sido objeto de vários encontros internacionais e mesmo nacionais, as formas mais adequadas para o restauro e conservação dos bens imóveis estão longe de ser consenso e, mesmo nos casos em que o são, as práticas demonstram que, na verdade, a necessidade de refletir teoricamente sobre 0 restauro e de agir em consonâncias com os princípios longamente discutidos e mundialmente estabelecidos para a área não é tão recorrente assim. Como afirma Françoise Choay,

Há meio século, apesar da poluição atmosférica, a química, a bioquímica e a biologia deram uma nova atualidade às teses de Ruskin, permitindo atuar de forma não traumática sobre a "saúde" dos monumentos. Além disso, pode-se considerar aceito não apenas o princípio de conservação

${ }^{13}$ CASTRIOTA, Leonardo Barci. Op. cit., pp. 103.

${ }^{14}$ Expressão que já parece pejorativa ou depreciativa, ainda que estes bens também façam parte da riqueza cultural brasileira. 
dos acréscimos antigos que se fizeram aos monumentos e aos bairros históricos, mas também a técnica do diradamento de Giovannoni, que atualmente encontra um precioso auxiliar nos estudos de morfologia urbana. Poder-se-ia considerar definitiva a condenação das reconstituições. Pensava-se que eram universalmente reconhecidas as regras de restauração formuladas por Boito, em especial aquela que manda indicar de forma clara todas as intervenções modernas, e de que se encontram magistrais demonstrações em todo o mundo [...]. Todos esses princípios, regras, preceitos, devidamente argumentados e refinados nos últimos cem anos, pareciam estar plenamente estabelecidos, fora de qualquer questionamento. Mera ilusão.

Reconstituições "históricas" ou fantasiosas, demolições arbitrárias, restaurações inqualificáveis tornaram-se formas de valorização correntes. $^{15}$

A transformação da cultura em mercadoria a ser consumida, processo que teve início por volta dos anos 1970, mas que se acentuou sobremaneira na última década do século $\mathrm{XX}$, acarretou uma verdadeira espetacularização da vida, cujo cenário passa a ser a própria cidade. ${ }^{16}$ Novos edifícios e conjuntos edificados são erguidos em áreas antes abandonadas e deterioradas para abrigar museus ou centros culturais - as novas catedrais da contemporaneidade $^{17}$ - ou ainda para outros usos institucionais. Essas construções têm como meta recuperar o espaço urbano e atrair novos investimentos para a área, transformando seu perfil sócio-econômico. Também os centros históricos e as áreas portuárias e industriais, degradados pelo abandono ou fim de suas funções produtivas, passam por intervenções que visam não apenas sua reinserção na dinâmica urbana, mas também, e prioritariamente, destacá-los como produtos a serem culturalmente consumidos através do chamado "turismo cultural".

De fato, nos últimos anos a preservação e recuperação de áreas históricas vêm adquirindo destaque no conjunto das ações de gestão urbana que visam à inserção das cidades no circuito cultural internacional, como meio de fortalecer a indústria turística, calcada na identidade local. ${ }^{18}$

${ }^{15}$ CHOAY, Françoise. Op. cit., pp. 213-214.

16 A respeito da espetacularização do espaço urbano, destacam-se aqui duas publicações, são elas: BOYER, M. Christine. The city of collective memory: its historical imagery and architectural entertainments. Cambridge / London, The MIT Press, 1996; SORKIN, Michael (Ed.). Variaciones sobre un parque temático. La nueva ciudad americana y el fin del espacio público. Barcelona: Gustavo Gili, 2004.

17 Para Kimmelman, os museus de arte contemporânea seriam encarados como as "novas catedrais" do nosso tempo. Ver: KIMMELMAN, Michael. "O futuro dos museus no século XXl", In: Jornal do Brasil. Rio de Janeiro, 11 set. 2001, pp. 08.

${ }^{18}$ Identidades 0 mais das vezes, deliberadamente forjadas, como bem esclarecem os estudos feitos por Eric Hobsbawm: HOBSBAWM, Eric \& RANGER, Terence (orgs.). A invenção das tradições. Rio de Janeiro: Paz e Terra, 1997. 
O patrimônio arquitetônico tornou-se, hoje, cenário revestido de valores mercadológicos, descompromissados com o passado e com o lugar tendência global que reflete a mundialização das relações, dos valores e das manifestações culturais. ${ }^{19}$

Esta tendência de revalorização de áreas degradadas através de sua transformação em espaços para o lazer e o consumo, se por um lado pode ser vista como um benefício, afinal traz novamente para a vida da cidade regiões até então dela alijadas, por outro, peca pelos meios de que se vale para fazê-lo.

A despeito do fato de que muitos temas afeitos à restauração de edificações e das áreas urbanas tenham sido codificados em numerosos documentos internacionais (tais como a Carta de Restauro de Atenas, a Carta de
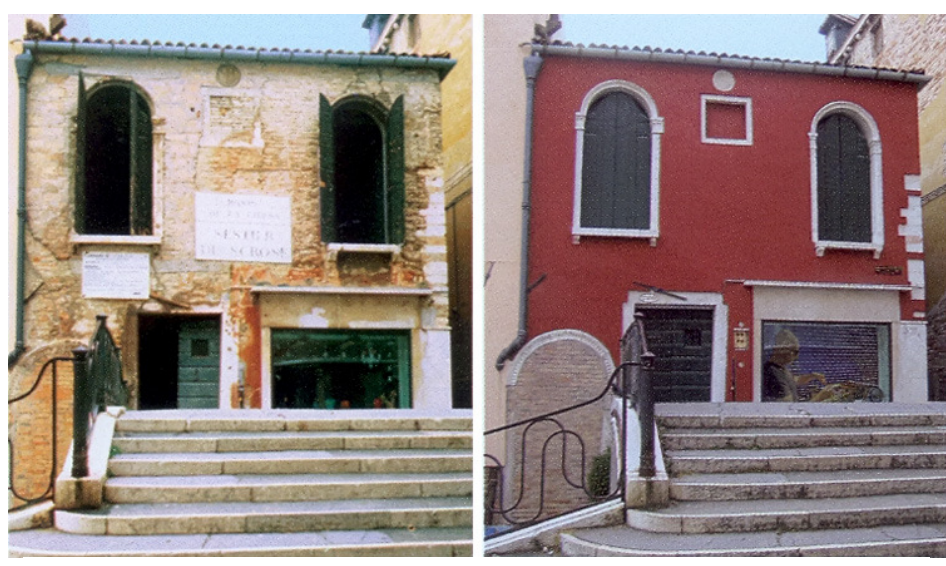

Fig. 27/28 - Casa em Veneza, antes e depois da intervenção. Fonte: DOGLIONE, 2008, pp. 169. Veneza, a Declaração de Amsterdã, a Carta de Washington, etc.), aceitos e ratificados por centenas de países ao redor do globo, multiplicam-se as intervenções em bens de reconhecida importância cultural que ignoram completamente tais postulados, justificados por questões econômicas e políticas, muito mais do que em razão das questões culturais, que deveriam fornecer os princípios de ação. ${ }^{20}$ As demolições e posteriores reconstruções "em estilo", embasadas em argumentos e estudos pseudocientíficos, são corriqueiras; quando não, as "restaurações" das fachadas são tão radicais que transformam por completo a imagem que o monumento teve durante décadas e, em alguns casos, séculos (Fig. 27/28). Alteração que representa uma mudança repentina não só na história do próprio monumento, tal como consolidada e estratificada pelo tempo, mas do contexto onde este se insere, que se vê invadido por um elemento, ao menos em aparência, completamente novo e descontextualizado. A aparência geral do conjunto tornase tão padronizada após a intervenção ou "revitalização", que locais antes

19 LUCHIARI, Maria Tereza Duarte Paes. "A reinvenção do patrimônio arquitetônico no consumo das cidades", In: GEOUSP - Espaço e Tempo. São Paulo, n. 17, 2005, pp. 95. 20 Maria Tereza Luchiari argumenta com muita precisão: "A apropriação dos bens culturais vem seguindo a conduta de transformação do patrimônio histórico em mercadoria, assim como a sua refuncionalização vem servindo agora à ideologia do consumo e não mais às práticas culturais representativas do sentimento de pertencimento das culturas e populações locais". Idem, pp. 96. 
peculiares passam a ser praticamente iguais, seja o bairro da Boca em Buenos Aires, seja Burano (Fig. 29), seja em qualquer das cidades brasileiras alvo do programa "Cores da Cidade" (Salvador, João Pessoa, etc). Na maioria dos casos, as limpezas radicais ou repinturas das fachadas são complementadas pela total transformação dos interiores, alvo de uma modernização a todo custo, visando adequá-los aos novos usos que são pensados como finalidade e não como um meio para a preservação. Percebe-se que os novos usos, ao invés de garantirem a preservação das memórias inscritas nos edifícios, se impõem sobre

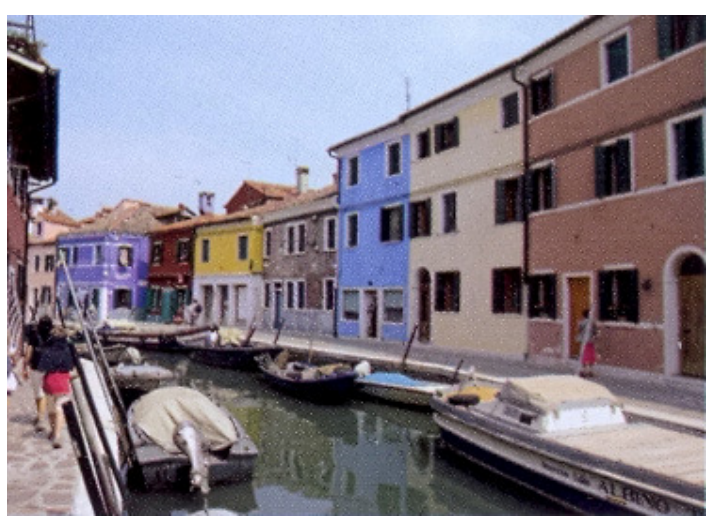

Fig. 29 - Burano, casario com fachadas repintadas. Fonte: DOGLIONE, 2008, pp. 170

estes, muitas vezes desrespeitando suas características e especificidades técnico-construtivas, fazendo-os meros invólucros para as atividades que ali se desenvolvem.

Com relação a tais intervenções, quase sempre se recorrem a outras expressões que não "restauração", preterida e substituída por termos como "revitalização", "recuperação", "requalificação", "reciclagem" ou ainda "retrofit". Estas novas expressões relativas às intervenções no patrimônio arquitetônico e em áreas urbanas de valor histórico e cultural abrem precedente para uma maior "liberdade de ação", necessária na medida em que, em tais ações, a conservação não é a finalidade primeira a se alcançar e a intervenção deixa de responder às razões de cunho cultural. Geralmente as obras são implementadas em prazos exíguos e, portanto, de modo superficial e descuidado, acarretando perdas irreparáveis aos monumentos que justamente deveriam conservar. A abordagem fachadista e centrada na aparência exterior dos monumentos também não implica em um compromisso com a autenticidade histórica e artística, deixando espaço para recriações e transformações que visam "adequar" o bem cultural às necessidades contemporâneas, bem como reforçar seu caráter "histórico" e "patrimonial". ${ }^{21}$

Seja em monumentos isolados, seja em conjuntos urbanos ou centros históricos, os pressupostos a guiar tais "revitalizações" nada têm em comum com

21 Françoise Choay comenta sobre o caso da Alemanha, em que as reconstruções dov'era, com'era do segundo pós-guerra (legítimas do ponto de vista social e mesmo psíquico naquele momento traumático), geram uma onda de demolições tardias de vários centros antigos, 'tendo em vista reconstituições 'ideais' que Viollet-le-Duc não teria imaginado" (CHOAY, Françoise. Op. cit., pp. 214). 
a restauração e seu campo disciplinar, que presa 0 respeito absoluto pela substância material do passado como suporte das memórias coletiva e individual. Antes, o que se pode perceber é a completa ausência de critérios que visem efetivamente à preservação da memória, relegando-a ao papel de mercadoria superficial para ser consumida, juntamente com o "típico", o "tradicional" e o "vernacular", tradições inventadas e postas à fruição de uma reduzida parcela da população, posto que, geralmente, os habituais usuários do espaço são afastados em nome do "uso cultural", que torna o bem acessivel a poucos..$^{22}$ Ademais, as áreas e edificações nas quais se empreendem os projetos de revitalização passam a ser alvo de controle e fiscalização mais rígidos com relação aos usuários e usos que ali se desenvolvem. Procura-se transferir para 0 ambiente das ruas 0 aspecto de "segurança", "ordem" e "limpeza" típicos dos shoppings-centers, ${ }^{23}$ de modo a garantir 0 afluxo de visitantes e turistas, claramente elitizando-o.

Esta tendência à mercantilização dos espaços centrais e de áreas industriais e portuárias "recicladas" ou "revitalizadas" e a reinvenção de áreas degradadas através da inserção de novos elementos arquitetônicos, cujos exemplos se multiplicam nas últimas décadas (Barcelona, Bilbao, Londres, Baltimore, Toronto, etc.), não demorou a ser implantado no Brasil, como se verá em breve. Porém, esta não é a única possibilidade de intervenção no patrimônio ambiental urbano, que ainda conta com os instrumentos sólidos e conceitos idôneos provenientes do campo da resratração.

Ao contrário do que preconizam a quase totalidade das intervenções contemporâneas, a restauração, consolidada como campo disciplinar autônomo há pelo menos um século, reitera a necessidade de um respeito absoluto pela matéria original, seja do ponto de vista artístico, seja pelo viés histórico. 0 respeito à matéria original não implica em musealização ou imobilismo do patrimônio, ao contrário, como já se disse anteriormente admite-se que toda restauração acarreta transformações em maior ou menor escala, entretanto, tais transformações devem ser justificadas, fruto de escolhas conscientes e ponderadas, descartando-se a priori qualquer intervenção descuidada e

22 Como lembra Françoise Choay: "A embalagem que se dá ao patrimônio histórico urbano tendo em vista seu consumo cultural, assim como o fato de ser alvo de investimentos do mercado imobiliário de prestígio, tende a excluir dele as populações locais ou não privilegiadas e, com elas, suas atividades tradicionais e modestamente cotidianas" (CHOAY, Françoise. Op. cit., pp. 226).

${ }^{23}$ SANT'ANNA, Márcia. A cidade-atração..., op, cit., pp. 335. 
apressada. O reconhecimento de que um determinado bem é portador de valor cultural traz consigo o imperioso compromisso com sua manutenção e transmissão ao futuro da melhor forma possível, disponibilizando todas as técnicas e, principalmente, conhecimentos, a fim de que sejam garantidas as condições de preservação das memórias de que o bem cultural é a materialização. Comentando sobre a conservação de áreas ou zonas históricas nos centros urbanos, Giovanni Carbonara condena a redução das ações de tutela e conservação em políticas de caráter meramente esquemático. ${ }^{24}$ Relembra que, uma vez reconhecido (no sentido profundo da proposição brandiana) o valor histórico, artístico ou cultural de uma determinada área, é preciso que as questões vinculadas à salvaguarda sejam amparadas pelas propostas da teoria do restauro, desse modo, o critério primeiro e prevalente para qualquer intervenção deverá ser aquele estritamente cultural, apenas num segundo momento as motivações de ordem prática, econômica e de gestão deverão ser consideradas.

Com a crescente ampliação do rol de objetos passíveis de se enquadrarem como bens culturais e patrimoniais 0 debate no que respeita às questões metodológicas e sua aplicação às circunstâncias atuais torna-se cada vez mais imperioso. Longe de trilhar um caminho unívoco, várias formas de pensar e, conseqüentemente, de intervir sobre os monumentos históricos continuam a coexistir, entretanto, tendo em vista os grandes desafios da restauração nos dias atuais, percebe-se uma retomada do diálogo entre diferentes tendências. Estas aproximações não têm como objetivo a busca por um percurso único e exclusivo, mas de procurar, mantidas as diferenças, pontos de aproximação e a construção de uma política de atuação mais eficaz. ${ }^{25}$. Especificamente na Itália, dentre as tendências que podem ser notadas atualmente no campo da restauração nas quais o fim último de toda intervenção continua a ser a transmissão da melhor forma possível da herança do passado às gerações futuras, podem-se destacar três principais correntes: a "críticoconservativa" ou "posição central"; a "conservação integral" ou "pura conservação"; e a "manutenção-repristinação" ou "hipermanutenção". ${ }^{26}$

24 CARBONARA, Giovanni. Avvicinamento..., op. cit., pp. 429.

25 LUMIA, Chiara. Op. cit., pp. 7.

26 Sobre as diversas correntes contemporâneas da teoria do restauro, ver: KÜHL, Beatriz Mugayar. Preservação da Arquitetura Industrial..., op. cit., pp. 60-72. Ver também outras indicações bibliográficas ao longo do capítulo 1 deste trabalho. 
No horizonte comum entre as diferentes vertentes teóricas estão certos problemas unanimemente reconhecidos, quais sejam: a distância entre os desenvolvimentos teóricos e o fazer prático; o problema de uma formação específica e adequada no setor; a exigência da interdisciplinaridade e a capacidade de sua gestão; as questões de ordem econômica e política concernentes à tutela. ${ }^{27} \mathrm{~A}$ quase totalidade dos autores reconhece a necessidade de um aprofundado conhecimento teórico e metodológico para garantir a qualidade da intervenção e, em última instância, a própria conservação do objeto sobre o qual se intervém. É consenso que a baixíssima qualidade das operações que são levadas a cabo nos dias atuais tem como principal causa a ausência de critérios teórico-metodológicos consistentes.

Diante de uma prática de restauro cada dia mais distante do próprio restauro, a análise dos conteúdos e das formas de intervir praticadas por essas correntes italianas acima citadas podem lançar alguma luz sobre 0 assunto $e$ corroborar a crença de que é possível, mesmo na realidade atual, trabalhar de modo criterioso e comprometido com os princípios teóricos da restauração. Obviamente, o fato de haver, dentro de um mesmo país, diferentes posturas no campo, deve induzir a pensar sobre a clara necessidade de desenvolver um pensamento local sobre o restauro, que, ainda que se valha da experiência internacional, ganhe contornos locais e seja adequado à realidade de cada país e cultura. Não se trata, portanto, de uma defesa da adoção cega a uma ou outra escola de pensamento, mas de proceder segundo uma metodologia adequada $e$ verdadeiramente comprometida com a preservação, baseada em uma deontologia profissional.

A corrente conhecida como "crítico-conservativa" ou "posição central" parte de uma releitura dos escritos brandianos e do restauro crítico e, portanto, compreende que toda e qualquer decisão relacionada à preservação de bens culturais deve ser fruto de um juízo histórico-crítico fundamentado na história e na estética. As escolhas sobre remoção de adições ou reintegrações de lacunas devem estar calcadas em análise judiciosa de cada obra em particular, na qual se procure equacionar a dialética entre as instâncias estéticas e históricas, consideradas inerentes a todo bem cultural.

27 LUMIA, Chiara. Op. cit., pp. 7. 
Segundo Giovanni Carbonara, defensor do restauro como ato crítico e criativo, trata-se efetivamente de restauro quando o objetivo primeiro da intervenção é a conservação e transmissão ao futuro de uma obra à qual se atribui valor histórico, artístico ou ambiental. Essa intervenção deve ser implementada de modo a facilitar a leitura do bem cultural, porém sem que sejam canceladas as marcas que a passagem do tempo Ihe impingiu, com respeito absoluto pela matéria antiga (Fig. 30). ${ }^{28}$ Diferentemente do que se possa deduzir da expressão "respeito absoluto pela matéria antiga", isto não quer dizer

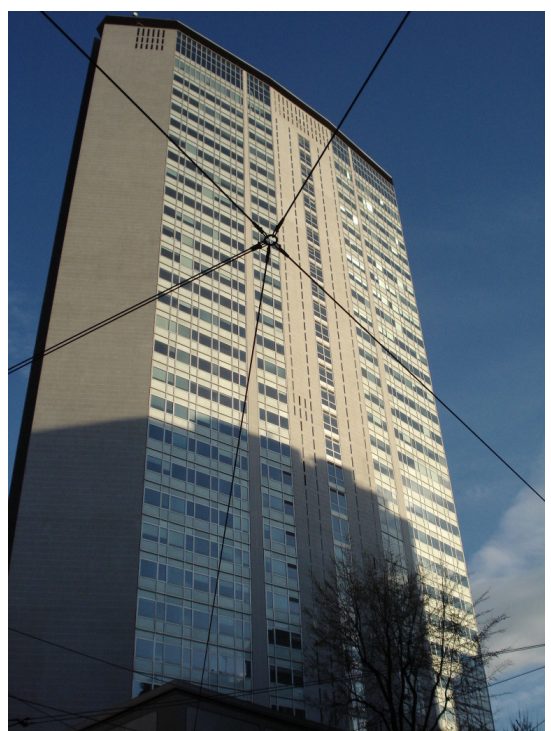

Fig. 30 - Arranha-céu Pirelli, Milão, 2008. Restauro crítico-conservativo. Foto: Claudia Reis congelamento ou ausência de modificações. Bem entendido, representa a necessidade de não se alterar de modo irreversível a matéria original, posto que o restauro é entendido como "hipótese crítica" e não com uma tese que se deseja provar a qualquer custo. Disso resulta uma postura respeitosa em relação ao monumento, que deve tender à conservação. Ainda assim, segundo o restauro crítico-conservativo, diversas soluções no âmbito de uma restauração devem advir do uso da criatividade e de uma competência e sensibilidade projetual, sempre subordinada ao objetivo da conservação.

No caso da corrente que defende a "pura conservação" ou "conservação integral", a relação dialética entre as instâncias estética e histórica dos bens culturais é negada. Para esses autores, a historicidade e a artisticidade não podem ser separadas, pois ambas são constituintes da obra de arte. Também segundo os defensores da conservação integral, a decisão quanto ao que deve permanecer e o que deve ser removido das várias etapas de uma dada obra não pode apoiar-se num juízo histórico-crítico, o qual, segundo propõe a historiografia contemporânea, tem pertinência relativa, decorrendo daí a defesa da manutenção de todas as estratificações da obra, mesmo que disso resulte uma leitura fragmentada ou descontínua. $\mathrm{A}$ instância história seria então a única objetiva e, portanto, legítima nas considerações sobre o que fazer e o que não fazer numa restauração, cujo objetivo seria apenas o de conservar a matéria original (incluindo-se aí todas as adições posteriores) do bem cultural. ${ }^{29}$ 
Para os partidários da pura conservação há uma separação entre 0 momento estritamente conservativo, que envolve apenas limpeza, tratamento e consolidação da matéria original da obra tal como chegou ao presente (Fig. 31), e o momento de inovação, autônomo e criativo, semelhante ao projeto do novo, ${ }^{30}$ necessário para adequar a edificação histórica às solicitações contemporâneas de uso e ocupação. Se no restauro crítico-conservativo todo 0

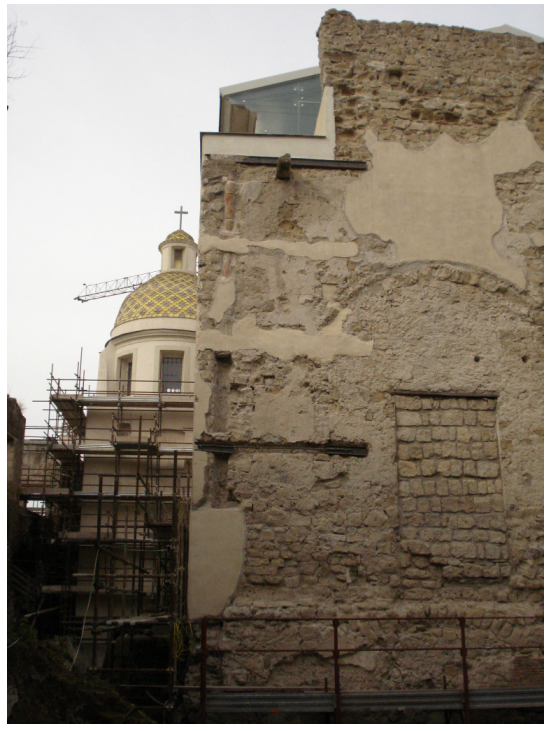

Fig. 31 - Templo-catedral, Pozzuoli, 2008. Exemplo da conservação integral. Foto: Claudia Reis processo de intervenção nos bens culturais é vinculado aos postulados do restauro, sejam os aspectos ligados à conservação propriamente dita, sejam às ações de remoção de adições ou preenchimento de lacunas, para os adeptos da conservação integral, trata-se de etapas distintas e autônomas: primeiro a conservação da matéria histórica e, depois, a adição de novas estruturas, projetadas em acordo com a criatividade arquitetônica contemporânea. ${ }^{31}$ Portanto, para a conservação integral, a postura que cabe ao restaurador é operar sempre através de adições e jamais com remoções.

Finalmente, a terceira corrente, conhecida como "hipermanutenção" ou "manutenção-repristinação", tende a tratar as intervenções nos monumentos como manutenções ordinárias e extraordinárias, utilizando técnicas, materiais e formas do passado, de modo a garantir uma leitura coesa e coerente do bem cultural, trabalhando por analogia e não segundo a distinguibilidade da ação contemporânea. ${ }^{32}$

Como já se disse no primeiro capítulo, esta vertente teórica tende a considerar o restauro arquitetônico como uma categoria distinta do restauro de objetos de arte, na qual a questão da autenticidade se coloca de modo diferente. ${ }^{33} \mathrm{~A}$ vulnerabilidade da arquitetura, exposta às intempéries e, com mais

\footnotetext{
30 Idem, pp. 61.

31 Sobre a conservação integral e sua relação com as outras duas tendências contemporâneas do restauro na Itália, a crítico-conservativa e a hipermanutenção, ver as interessantes colocações de Francesco Doglione: DOGLIONE, Francesco. Op. cit., pp. 35-40.

${ }^{2}$ Mas não se deve confundir analogia com mimeses ou cópia. Igualmente não se deve simplificar a teoria da hipermanutenção, relegando-a a apenas reproduzir monumentos. Só se restaura aquilo que existe, portanto, não há lugar para recriações fantasiosas ou de bens desaparecidos.

${ }^{33}$ Marconi afirma que: "Vorrei sottolineare, a questo punto, che l'architettura [...] è caratterizzata da parametri quantitativamente e qualitativamente diversi da quelli che caratterizzano gli oggetti d'arte" (MARCONI, Paolo. II restauro e l'architetto..., op. cit., pp.
} 
intensidade nos dias de hoje, à poluição atmosférica, leva à necessidade constante de manutenção para que a unidade semântica do contexto seja mantida. ${ }^{34}$ Essa manutenção, segundo Paolo Marconi, principal expoente da hipermanutenção, deve ser feita através da substituição de peças e materiais degradados por outros análogos, executados em com técnicas e materiais tradicionais, evitando, desse modo, os possíveis danos decorrentes da incompatibilidade físico-química (Fig. 32/33). Para defender a substituição dos
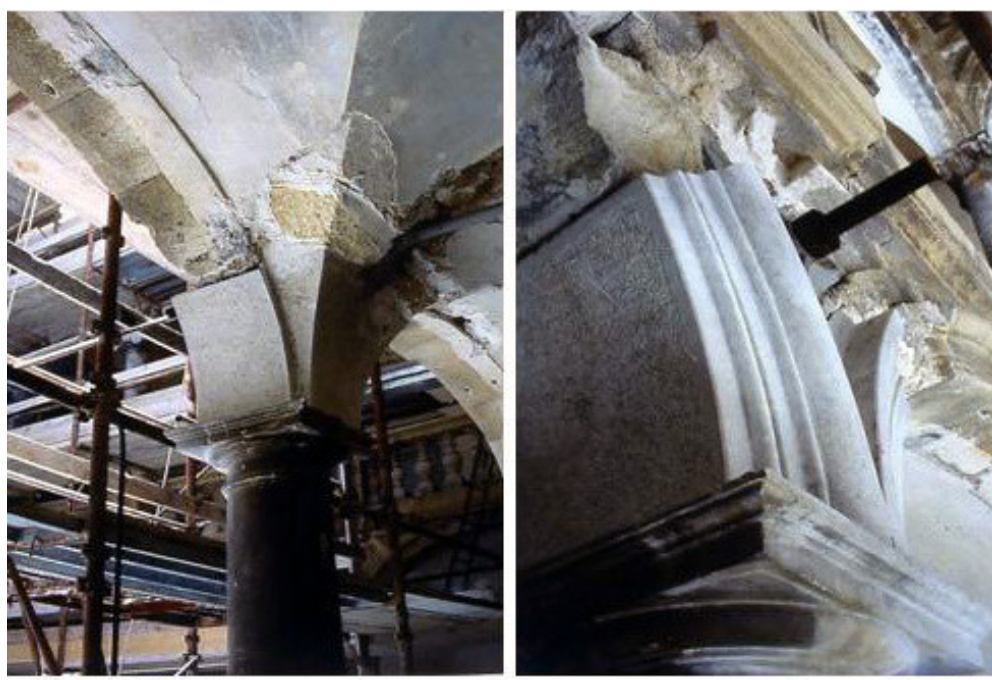

Fig. 32/33 - Palazzo Riccio di San Gioacchino, Trapani, restauro de repristinação, arq. Paolo Marconi, 1997. Fonte: www.paolomarconiarchitetto.it elementos degradados por outros similares, Marconi desenvolve a noção de "superfície de sacrifício", que se refere a partes da arquitetura que são fadadas ao desgaste $\mathrm{e}$, portanto, devem ser periodicamente substituídas, tais como rebocos, pinturas, telhas, etc.

Como se viu acima, há uma clara distinção entre as três vertentes teóricas, porém, apesar das diferenças, alguns

pontos são unânimes. Mesmo dentro da diversidade de meios e da pluralidade de formulações apresentadas por cada uma das escolas da contemporânea teoria da restauração, preconiza-se um respeito absoluto pela matéria antiga, reconhecida como documento de incontestável valor histórico e também estético, do que decorre a defesa da prudência e cautela, necessárias em qualquer intervenção. Ademais, reconhece-se a pertinência sempre relativa de qualquer proposição no campo da restauração e, portanto, reitera-se a exigência do

45). Procurando refletir sobre essa questão, Francesco Doglione coloca: "Ë pur vero che l'autenticità in architettura ha tratti diversi e più articolati rispetto a quella propria di un dipinto o di una scultura, tuttavia la consapevolezza che ogni parte costruita rappresenta il risultato e la testimonianza di 'saperi' o di 'regola d'arte', come lo stesso Marconi sostiene, accentua l'importanza della materia che ne conserva i segni e contribuisce cosi al significato dell'architettura. Appare sproporzionato allo scopo sostenere che l'autenticità materiale è ininfluente per riaprire la strada al ripristino [...]" (DOGLIONE, Francesco. Op. Cit., pp. 43).

34 TORSELLO, B. Paolo et alli, op. cit., pp. 45. 
exercício da razão, da moderação e da consciência da responsabilidade de tal ação cultural.

O objetivo comum é a correta interpretação do passado e a transmissão ao futuro da herança que chegou até nós, de modo que nossos sucessores possam estudar, interpretar e usufruir as mesmas obras que vemos hoje. Isso significa atuar respeitando a especificidade da obra sem destruir nada, conservando o mais possível e adotando para os acréscimos rigorosos critérios de compatibilidade (física, química e sobretudo estética) com o original. Na base de tudo deve estar sempre um profundo e pormenorizado conhecimento do monumento e de seu sítio, histórico-crítico e também científico e social. ${ }^{35}$

Em nenhum caso defende-se a destruição sucedida pela reconstrução hipotética de um bem cultural, pois a visão ocidental de monumento histórico está calcada na idéia de que cada obra é única e insubstituível em seu devir histórico e qualquer perda nessa área representa dano irreparável. A noção de tempo judaico-cristã, à qual pertence a tradição do Ocidente, nega a possibilidade de que reconstruções ex novo (por mais precisas e fiéis que sejam ao original) substituam as obras destruídas por qualquer razão. As cópias podem ter um valor simbólico (como no caso das reconstruções da Europa pós-Segunda Guerra Mundial) ou pedagógico (como no caso da reconstrução do Pavilhão da Alemanha de Mies van der Rohe para a exposição Universal de Barcelona de 1929 - uma maquete em escala 1:1, mas não o pavilhão destruído), ${ }^{36}$ mas em nenhum dos casos elas podem ser equiparadas à construção original e a substituição representa sempre um empobrecimento cultural.

Infelizmente, a adoção da reconstrução como elemento de preservação tem sido recurso dos mais utilizados, seja em âmbito internacional, como já se fez alusão, seja em solo brasileiro. Quando não se adota a prática da reconstrução total, as "revitalizações" ou outras operações pseudoconservativas são responsáveis por descaracterizações sucessivas em bens de importante valor cultural, como se verá nos exemplos brasileiros mostrados a seguir.

Retomando rapidamente o contexto em que o IPHAN se inseria dentro da estrutura governamental no início da década de 1990, viu-se que, durante a curta gestão do presidente Fernando Collor de Mello ocorreu um desmonte de

35 CAMPANELLI, Alessandro Pergoli. "Restauro contemporâneo: algumas abordagens", In: Revista CPC, São Paulo, n. 7, nov. 2008/abr. 2009, pp. 29.

${ }^{36} \mathrm{~A}$ esse respeito ver a resenha de Beatriz Kühl do livro "Clonagem Arquitetônica", de autoria da espanhola Ascensión Hernández Martínez: KÜHL, Beatriz Mugayar. "O problema da reprodução de obras arquitetônicas", In: Revista CPC, São Paulo, n. 7, nov. 2008/abr. 2009, pp. 131. 
diversas entidades da Administração Pública Federal, muitas das quais relacionadas com a área da cultura, como parte do projeto de enxugamento da máquina estatal. Assim, a Secretaria de Patrimônio Histórico e Artístico Nacional é transformada em Instituto Brasileiro do Patrimônio Cultural, ${ }^{37}$ autarquia diretamente ligada à Presidência da República. A nova estrutura regimental do IBPC $^{38}$ extingue o Conselho Consultivo, fato que acarreta a paralisação das atividades do órgão. A "normalidade" volta à instituição no início de 1992, quando um novo decreto restabelece o Conselho Consultivo, que passa a ter como atribuições "examinar, apreciar e opinar sobre questões relacionados ao tombamento" ${ }^{39}$ Porém, as dificuldades operacionais da área do patrimônio - que sempre foi deficitária em termos de orçamento e de pessoal - continuou a ser fortemente sentida, agravada pela redução brutal dos investimentos do Estado na área da cultura.

Diante da retração do papel do Estado nos investimentos em cultura, novos instrumentos legais são criados, visando à participação direta da iniciativa privada, através de incentivos fiscais. A primeira lei nesse sentido foi promulgada ainda na gestão de Celso Furtado como Ministro da Cultura, em 1986, mas recebeu duras críticas por ser considerada muito liberal e com poucos instrumentos de gestão e controle dos recursos cedidos por meio da renúncia fiscal. ${ }^{40}$ Extinta pelo presidente Collor de Mello, a Lei Sarney foi substituída pela Lei Rouanet, ${ }^{41}$ cujo nome se deve ao autor do texto legal, o embaixador Sérgio Paulo Rouanet, e que cria o Programa Nacional de Apoio à Cultura (PRONAC), prevendo o estabelecimento de três fontes de financiamento: o Fundo Nacional da Cultura - FNC, os Fundos de Investimento Cultural e Artístico - FICART, além de um mecanismo de mecenato, através da renúncia fiscal, chamado de Incentivo a Projetos Culturais.

${ }^{37}$ Cf.: Lei n. 8.029, de 12 de abril de 1990, inciso II do art. $2^{\circ}$.

38 Estabelecida através do Decreto n. 99.602, de 13 de outubro de 1990, Anexo I.

39 Decreto n. 335, de 11 de novembro de 1991, art. 6․․

40 Lei n. 7.505, de 02 de julho de 1986, conhecida como "Lei Sarney". Segundo Simone Schneider, "Para viabilizar a captação de recursos privados para os projetos culturais [a Lei] exigia apenas que a instituição ou o produtor cultural solicitantes fossem previamente cadastrados pelo Estado [...] deixando as negociações sobre valores, formas de captação e uso dos recursos ao mercado". SCHNEIDER, Simone Marafon. Cultura é desenvolvimento: um panorama da atuação do BNDES em projetos de restauro (1997-2007). Rio de Janeiro: CPDOC/PPGHPBC/FGV, Dissertação de Mestrado, 2008, pp. 55-56.

41 Lei ํ․ . 8.313, de 23 de dezembro de 1991. 
O Fundo Nacional da Cultura teria como objetivo o financiamento a fundo perdido, com verbas do Tesouro Nacional, de projetos culturais pouco atraentes ao mercado privado, corrigindo desigualdades na distribuição dos recursos para a cultura. "Em suma, trata-se de um instrumento compensatório, voltado principalmente para atender a demanda que encontra dificuldades de desenvolvimento e atendimento no mercado, e que deve ser apoiada pelo Estado". ${ }^{42} \mathrm{Na}$ prática, o FNC não foi eficiente na correção das distorções do mercado, que concentra seus investimentos no eixo Rio-São Paulo, deixando outras regiões do país desassistidas e sem recursos. Segundo bem coloca Simone Schneider, "os fundos nunca vingaram, fazendo da Lei Rouanet a formalização da cultura no mercado através única e exclusivamente da transferência de recursos públicos para o setor privado" ${ }^{43}$

Certamente a faceta mais conhecida da Lei Rouanet refere-se ao mecenato, que faculta a pessoas físicas ou jurídicas um abatimento no imposto de renda para as contribuições ao FNC ou apoio a projetos culturais previamente aprovados por uma comissão composta por representantes do governo e de instituições culturais. A lei também pode ser usada como incentivo a projetos de restauração e conservação de bens tombados pelo governo federal, desde que sejam previamente aprovados pelo IPHAN.

A Lei Rouanet, principalmente após as diversas modificações que sucessivas vezes the foi imposta, continua a ser um importante instrumento de incentivo ao restauro de monumentos tombados em nível federal. Proprietários e, principalmente, grandes empresas que querem vincular seu nome a ações culturais, têm recorrido a esse mecanismo de incentivo. Porém, em que pese 0 aumento no investimento privado no setor, "o patrimônio cultural continuava precisando de dotação orçamentária; continuava sendo uma questão de Estado, como na Era Vargas e na ditadura militar" ${ }^{34} \mathrm{E}$ nesse âmbito, é que terá origem 0 Programa Monumenta, um novo mecanismo para dinamizar a área do patrimônio.

Durante a gestão de Francisco Weffort no MinC, a partir de 1995, tem início o estabelecimento do programa para revitalização de sítios históricos, através de parceria com o Banco Interamericano de Desenvolvimento - BID, que

\footnotetext{
${ }^{42}$ SANT'ANNA, Márcia. A cidade-atração..., op. cit., pp. 234.

${ }^{43}$ SCHNEIDER, Simone Marafon. Op. cit., pp. 59.

${ }^{44}$ Idem, pp. 64.
} 
dará origem ao Monumenta, principal programa de financiamento para as ações de recuperação e preservação do patrimônio histórico no Brasil até o presente.

A crise institucional decorrente das mudanças regimentais e políticas vivida pelo órgão federal de preservação não é acompanhada por transformações conceituais propriamente ditas, mas pelo acirramento de certas tendências que já se insinuavam desde os anos 1970/80, qual seja, a exploração do patrimônio cultural como mercadoria. De fato, a partir da segunda metade da década de 1990 a preservação do patrimônio vem fortemente atrelada ao marketing urbano e às estratégias de dinamização de áreas degradadas, tais como as regiões portuárias e os centros históricos. Como lembra Rogério Leite Proença,

Essa relação entre patrimônio e economia não é algo novo nas políticas de preservação. [...] Embora já contemplasse uma crescente participação do setor privado, como forma de suprir as deficiências orçamentárias e desonerar o Estado dos gastos com o patrimônio, havia [nos anos $70 \mathrm{e}$ 80] a preponderância de um discurso social, voltado ao desenvolvimento urbano e regional, através do incremento do turismo cultural. [...] 0 que muda, portanto, a partir dos anos 90, não é a orientação preservacionista voltada ao turismo, mas a lógica de participação dos setores público e privado nas políticas de patrimônio, que altera os critérios da preservação. A tônica central do "planejamento estratégico", eufemismo acanhado para gentrification e espécie de onda neo-conservadora do urbanismo, é justamente a transformação da cultura em um segmento do mercado e da própria economia em um assunto cultural. 45

De fato o PCH, implementado entre os anos 1973 e 1983, pode ser tido como antecessor do Programa Monumenta, posto que se apresenta como uma parceria entre diversas entidades do governo federal e local e uma organização internacional cujo objetivo principal era o desenvolvimento do turismo nas cidades históricas, de modo a trazer recursos para sua manutenção e conservação. $^{46} \mathrm{O} \mathrm{PCH}$ fundamentava-se na idéia de que, com os altos investimentos do setor público, as áreas deterioradas da cidade seriam saneadas e, com isso, atrairiam novos investimentos, desta feita provenientes da

45 LEITE, Rogério Proença. Contra-usos da cidade. Lugares e espaço público na experiência urbana contemporânea. Campinas: Ed. Unicamp; Aracaju: Ed. UFS, 2004, pp. 70-71.

${ }^{46}$ Como já foi esclarecido no capítulo anterior, o Programa Integrado de Reconstrução das Cidades Históricas (PCH) surge, com apoio da UNESCO, no contexto da descentralização das atividades de preservação do patrimônio no Brasil e também sob égide do que estabelecia as Normas de Quito (exploração turística dos centros históricos, com vistas à geração de renda para sua manutenção). As instituições envolvidas eram: Secretaria de Planejamento da Presidência da República (SEPLANPR), IPHAN e EMBRATUR, todas na esfera federal; da esfera estadual participavam Fundações, Institutos e Secretarias vinculadas à área da cultura. Cf.: SANT'ANNA, Márcia. A cidade-atração..., op. cit., pp. 254. 
iniciativa privada, e ganhariam um público permanente, evitando-se, desse modo, o retorno ao estado de degradação precedente. Mas as ações do PCH não surtiram o efeito desejado e, poucos anos depois e apesar dos maciços investimentos do poder público, as áreas de projeto voltaram à antiga condição de deterioração.

$\mathrm{Na}$ avaliação de especialistas, as políticas que aliavam preservação e desenvolvimento turístico, nos anos 70, não deram certo por vários fatores. Entre os mais citados estão a sazonalidade e a instabilidade próprias da atividade; sua fragilidade diante das crises econômicas que assolaram a América Latina, nos anos 80; a retração e descontinuidade dos investimentos públicos, e a ausência de solução para problemas ligados ao desenvolvimento econômico e social. ${ }^{47}$

Porém, a despeito das dificuldades encontradas na experiência anterior e, principalmente, animados pelos resultados obtidos em intervenções ocorridas em países europeus e nos Estados Unidos, em meados dos anos 1990 dá-se início à montagem do Programa de Preservação do Patrimônio Histórico Urbano ou Monumenta, executado pelo Ministério da Cultura (MinC) e financiado pelo BID.

Com a parceria entre MinC e BID na instituição do Programa Monumenta ocorre um esvaziamento da importância do IPHAN como órgão central de preservação, que se vê alijado das funções de direção e coordenação da execução do Programa, para as quais são nomeados funcionários terceirizados. ${ }^{48}$ Ao IPHAN coube apenas 0 gerenciamento das ações de fortalecimento da própria instituição, um dos componentes do Programa que prevê o financiamento de inventários, normas, banco de dados e manuais técnicos, a aquisição de equipamentos e serviços de informática, treinamento e capacitação de pessoal e a concepção de um sistema para o estabelecimento de prioridades de conservação. ${ }^{49}$

Apesar de não ter poder direto de decisão sobre as ações de preservação levadas a cabo pelo Monumenta, por obrigação legal, o IPHAN continua a apreciar todos esses projetos, que devem contar com a aprovação do órgão, por incidirem obrigatoriamente em bens tombados em nível federal (uma

\footnotetext{
47 Idem, pp. 255.

${ }^{48}$ A coordenação do Programa, análise e aprovação das solicitações de financiamento, supervisão e acompanhamento de sua implementação são atribuições da Unidade Central de Gerenciamento - UCG, criada no MinC especialmente para tal tarefa. Cf.: BRASIL. Regulamento Operativo do Programa de Preservação do Patrimônio Histórico Urbano - Monumenta. 1200/OC-BR, Versão setembro 2006, pp. 10.

49 Idem, pp. 13.
} 
das pré-condições para estabelecimento do convênio e implementação do Programa em qualquer município). ${ }^{50}$ Ainda assim, como coloca Márcia Sant'Anna,

No plano federal, é mesmo possivel afirmar que os novos programas marcaram o declínio do IPHAN como protagonista da área de preservação, com a redução do seu papel à execução de tarefas circunscritas a questões de orientação e fiscalização. Os anos 90 conferiram ao IPHAN um papel protocolar e de legitimação de projetos elaborados e executados, muitas vezes, à sua revelia, papel do qual a instituição não soube nem teve força política para se esquivar ou impor outra visão. ${ }^{51}$

O modelo de intervenção imposto pelo Programa Monumenta parte do pressuposto de que apenas os recursos públicos não são suficientes para a manutenção e conservação das áreas históricas e, por isso, demanda a conjugação de esforços com a iniciativa privada. A questão da sustentabilidade é central na implementação do acordo e para a aprovação de projetos no âmbito do Monumenta, tal como estabelecido no Regulamento Operativo. ${ }^{52}$ Para isto, são estimulados nos projetos a adoção dos usos turísticos e culturais considerados aptos para dar o desejado retorno financeiro do investimento feito, repetindo fórmulas antigas e que demonstraram não serem tão eficientes assim para alcançar os objetivos propostos.

Segundo Pedro Taddei Neto, Coordenador Nacional do Programa Monumenta, no período de 1997-2002,

Para alcançar aqueles objetivos de replicação e de sustentabilidade na manutenção das edificações, sítios ou conjuntos recuperados, o Monumenta não pôde ater-se exclusivamente às obras de restauro daquelas áreas mais degradadas. Foi preciso também prever incentivos à atividade econômica e à produção cultural autóctone, além de buscar o fortalecimento, seja dos órgãos federais envolvidos, seja dos órgãos locais e até de gestores privados de atividades culturais, gestores de grupos de teatro, de equipamentos, de museus etc. ${ }^{53}$

${ }^{50}$ Conforme estabelecido no Regulamento Operativo do Programa, o convênvio com 0 Monumenta só pode ser firmado com municípios considerados Sítios Históricos Urbanos Nacionais - SHUN ou possuidores de no mínimo um Conjunto Urbano de Monumentos Nacionais - CUMN. Ver: BRASIL. Regulamento Operativo..., op. cit., pp. 7.

${ }^{51}$ SANT'ANNA, Márcia. A cidade-atração..., op, cit., pp. 319.

52 O Regulamento Operativo estabelecendo item D2 do título II, dentre outros requisitos, que: "Os Projetos serão elegíveis quando: (i) as análises de viabilidade econômica e financeira do conjunto das intervenções e ações propostas, desenvolvidas de acordo com os procedimentos descritos nos Anexos B e C, apresentarem resultados positivos". Cf.: BRASIL. Regulamento Operativo..., op. cit., pp. 15-16.

${ }^{53}$ TADDEI NETO, Pedro. "Preservação sustentada de sítios históricos: a experiência do Programa Monumenta", In: Políticas culturais para o desenvolvimento: uma base de dados para a cultura. Brasília: UNESCO Brasil, 2003, pp. 111-112. 
Diferentemente das noções de cidadania e inclusão social que marcaram o discurso preservacionista nos anos 1980, as novas modalidades de tratamento do patrimônio histórico urbano voltam-se para a localização estratégica dos sítios, para seu potencial de atração de recursos e de visibilidade e repercussão na mídia. ${ }^{54}$ Também as formas de tratamento seguem uma postura mais preocupada com a imagem do monumento do que com a efetiva preservação do bem cultural, no respeito de sua história e de suas características técnico-construtivas.

Tais aspectos poderão ser melhor apreciados a partir da análise das intervenções vinculadas ao Programa localizadas no Bairro do Recife (Recife/PE). Mas antes de passar a essas intervenções, duas outras obras de restauração, executadas antes do estabelecimento do Monumenta, serão aqui apresentadas - Forte da Barra Grande (Guarujá/SP) e Forte de São João (Bertioga/SP) -, de modo a oferecer um instrumento mais completo de exame das políticas de preservação e, especificamente, de restauração do IPHAN a partir dos anos 1990.

O Forte de Santo Antonio da Barra Grande (Fig. 34/35/36), localizado na Ilha de Santo Antonio, no Guarujá, construído por volta de 1580, tem um longo ciclo de abandono e reconstruções, algumas das quais mais conservadoras e outras que impuseram modificações mais sensíveis na estrutura original. As obras mais significativas de reforma são as de 1885, na qual o "telhado colonial foi substituído e o alpendre central recebeu as arcadas coroadas por platibanda como se vê hoje". ${ }^{55} 0$ processo de tombamento é aberto no ano de $1950,{ }^{56}$ mas o tombamento definitivo só acontecerá em 1964 , quando o forte é inscrito no Livro de Tombo Histórico, tombamento que, em 1979, é estendido ao Fortim da Praia do Góis, ao Portão Espanhol e à área que envolve todos os monumentos.

Somente em 1993 têm início as obras de restauração do local, cujo projeto foi desenvolvido pelo arquiteto Victor Hugo Mori, em parceria com 0 então Superintendente Regional do IPHAN São Paulo, o arquiteto Antonio Luiz Dias de Andrade, o Janjão. Segundo Mori,

54 SANT'ANNA, Márcia. A cidade-atração..., op, cit., pp. 332.

55 LEMOS, Carlos A. C.; MORI, Victor Hugo; D'ALAMBERT, Clara C. Patrimônio: 70 anos em São Paulo. São Paulo: 9a S.R./IPHAN, 2008, pp. 124.

56 Processo: 0441-T-50. Fonte: Base de dados digital do Arquivo Noronha Santos (http://www.iphan.gov.br/ans/inicial.htm). 
Das últimas obras de restauro efetuadas pelo IPHAN em São Paulo, o projeto da Fortaleza da Barra Grande na llha de Santo Amaro foi, sem dúvida, o mais polêmico. Incitou manifestações públicas de aprovação e repúdio.

$[\ldots]$

Passados cinco anos do início do movimento pró-Fortaleza [...], pressente-se uma quase unanimidade, quanto à aprovação do critério arquitetônico adotado. A visão do monumento paulatinamente ressurgindo, branco e vigoroso, na paisagem do Canal da Barra, depois de décadas de abandono, vandalismo e arruinamento, arrefece as diferenças conceituais de opiniões, sendo aos poucos substituídas pela cumplicidade na ressurreição deste monumento. ${ }^{57}$

0 partido arquitetônico

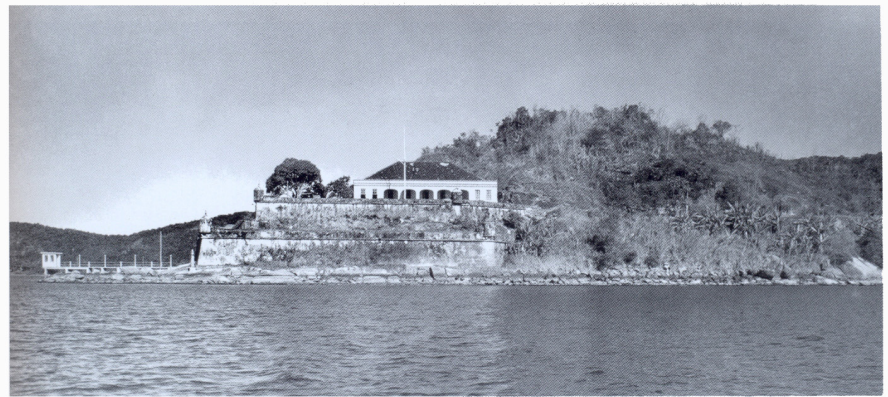

adotado no projeto de restauro, ainda segundo Victor Hugo Mori, foi "sugerido" por Lucio Costa quando este emitiu parecer favorável à abertura do processo de tombamento, em 1950. Neste parecer, o Dr. Lucio
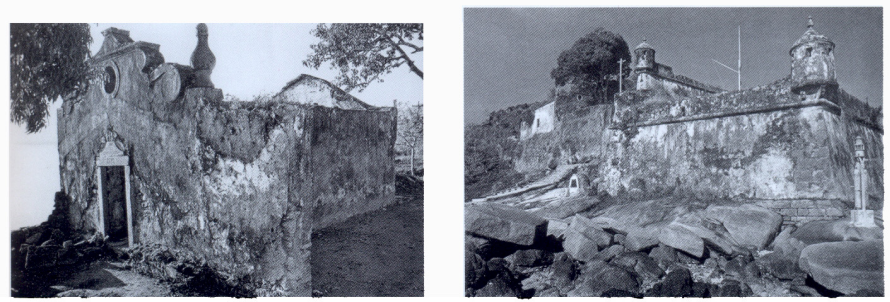
indica que, dadas as sucessivas (e, a seu ver, indevidas) reformas, "na eventualidade de obras de adaptação, [cabe] beneficiá-lo com novo telhado (mais baixo e com telhas de modelo

Fig. 34/35/36 - Forte da Barra Grande, Guarujá/SP, aspecto em 1944. Fonte: LEMOS et alli, 2008, pp. 125. antigo) recompondo-se ainda os arcos e demais vãos modernizados". ${ }^{58}$ Dessa diretriz dada pelo antigo chefe da DET, surge a defesa da manutenção das transformações por que passou 0 edifício, negando a possibilidade de retorno aos aspectos pretéritos do monumento, seja aquele do século XVI, seja o do século XVIII:

A hipótese de retorno aos dois primeiros séculos implicaria, na prática, em destruir todo o conjunto existente, mantendo-se apenas as duas baterias, ainda assim diminuindo-se a altura em 6 palmos (acrescentados por Massé) e manter o quartel em sua tipologia palladiana, especialmente semelhante às casas bandeiristas do planalto, porém mais baixo que a construção atual e sem as arcadas acrescentadas no século XIX. A outra hipótese de retorno às feições do século XVIII também implicaria na demolição e reconstrução de $50 \%$ do quartel, ainda assim calcado em conjeturas, pois inexistem evidências materiais ou iconográficas

57 MORI, Victor Hugo. "A História do Restauro da Barra Grande: de Lúcio Costa à participação de todos", In: Leopoldianum - Revista de Estudos e Comunicações da Universidade Católica de Santos, n. 64, volume XXIII, agosto 1997.

${ }^{58}$ COSTA, Lucio. Op. cit., pp. 96. 
confiáveis para definir os elementos como portas, janelas, detalhes técnicos, cobertura etc. ${ }^{59}$

A solução adotada é, pois, a manutenção de todas as marcas do passado, embasada na Teoria brandiana e na Carta de Veneza, e a recuperação do antigo volume arquitetônico, sugerida pelo autor do projeto como meio de restabelecer a "unidade potencial da obra de

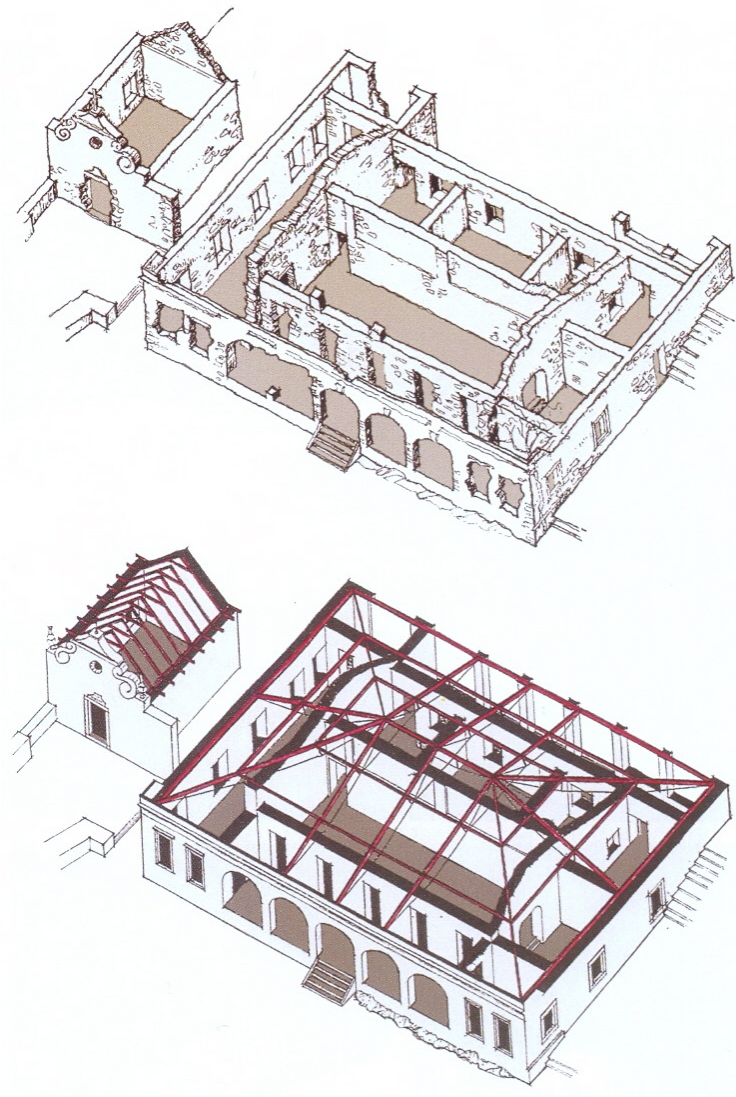

Fig. 37/38 - Forte da Barra Grande, perspectivas antes e depois do restauro. Fonte: LEMOS et alli, 2008, pp. 127. arte", objetivo do restauro para Cesare Brandi.

Para tanto, adota-se uma "delicada estrutura metálica, moderna e discreta" para cobrir 0 edifício principal e a capela (Fig. 37/38), opção que "revela a obediência aos termos da Carta de Veneza", ao adotar formas e materiais contemporâneos na adição, de forma respeitosa. ${ }^{60}$

As obras de restauração do Forte de São João, em Bertioga, executadas a partir de 1997, seguem os mesmos princípios das empreendidas no Guarujá, isto é, a recuperação volumétrica do espaço sem cancelar as modificações feitas nas sucessivas obras de reparo/reforma.

Construída por volta de 1530, a Fortaleza de São João da Bertioga foi reconstruída sucessivas vezes, substituindose as edificações rudimentares do início por outras mais sólidas e duradouras. Assim como o Forte da Barra Grande, o Forte de São João, que hoje abriga o Museu João Ramalho, passou por períodos de abandono (Fig. 39) e sucessivas reconstruções, tendo sido incluída nos inventários do SPHAN já em 1937 e tombada em 1940, nos livros Histórico e das Belas Artes. ${ }^{61}$

59 MORI, Victor Hugo. Op. cit.

60 Idem, ibidem.

61 Processo: 0219-T-39. Inscrições: Livro de Belas Artes: 278, em 19 fev. 1940 e Livro Histórico: 123, em 19 fev. 1940. Fonte: Base de dados digital do Arquivo Noronha Santos (http://www.iphan.gov.br/ans/inicial.htm). 
Logo após o tombamento, em 1942, foram empreendidas obras de restauro às expensas do Ministério do Exército e sob a supervisão do chefe da regional paulista do SPHAN, Luis Saia, o qual optou por "manter o projeto tal como se encontrava" posto não haver "documentação histórica capaz de elucidar definitivamente a configuração arquitetônica do quartel".62 Descobertas as plantas de 1871 e de 1896 foi possível estabelecer qual era a "configuração arquitetônica" que a construção adquiriu após as reformas executadas pelo

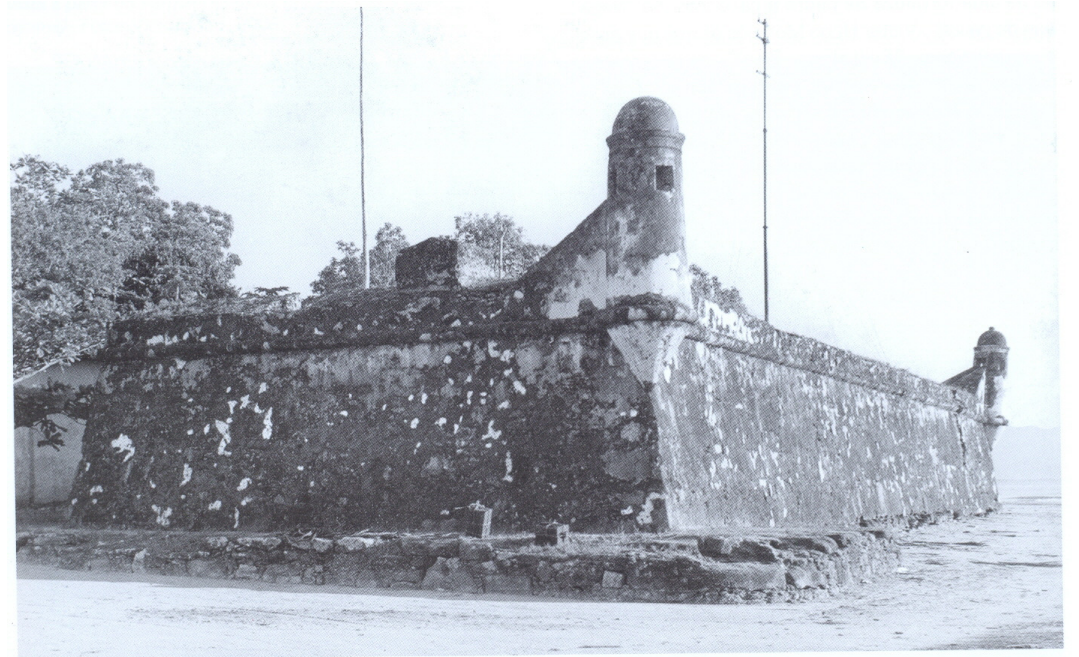

Fig. 39 - Forte de São João da Bertioga, Bertioga, 1937. Fonte: LEMOS et. alli., 2008, pp. 79. engenheiro militar Rufino José Felizardo e Costa em 1817. A partir disso,

[...] o IPHAN decidiu restaurar àquela feição [a de 1817] o edifício do quartel, mas não de forma ortodoxa. Ao mesmo tempo em que retoma a tipologia da planta como arquitetura militar, o projeto introduz materiais e desenhos novos e modernos, não para restaurar a forma, mas para 'revelar a unidade potencial' do monumento. $A$ espacialidade do edifício do quartel, definida pelos vestígios remanescentes, será completada com a construção de um telhado estruturado sobre perfis de aço, respeitando a volumetria definida na obra de 1817. A antiga cozinha será executada com materiais modernos, as obturações nas rachaduras serão refeitas com concreto armado, 0 revestimento da cantaria será refeito com argamassa de cimento. ${ }^{63}$

A premissa de respeito pela historicidade do bem cultural adotada na restauração dos Fortes da Barra Grande e São João, em clara convergência com a Carta de Veneza e com a Teoria brandiana, ${ }^{64}$ resvala quando se analisa 0 tratamento das superfícies, que, como se pode visualizar claramente nas fotografias pós-restauro (Fig. 40/41), são cuidadosamente repintadas, apagando completamente as marcas da passagem do tempo representada pela pátina.

62 Apud: MAYUMI, Lia. Monumento e autenticidade..., op. cit., pp. 118.

63 Idem, ibidem.

$64 \mathrm{Na}$ Carta de Veneza, art. 11, afirma-se que "as contribuições válidas de todas as épocas devem ser respeitadas" (Carta de Veneza - 1964, In: Cartas Patrimoniais..., op. cit., pp. 93.). Já o segundo princípio do restauro enunciado por Cesare Brandi é: "a restauração deve visar ao restabelecimento da unidade potencial da obra de arte, desde que isso seja possivel sem cometer um falso artístico ou um falso histórico, e sem cancelar nenhum traco da passagem da obra de arte no tempo" (BRANDI, Cesare. Op. cit., pp. 33. Grifos nossos). 
Ainda que sem optar pela reconstrução maciça, tal como se fazia nos tempos da "fase heróica", e mesmo respeitando as transformações sucessivas do bem cultural, o aspecto do monumento após a finalização dos trabalhos de restauro não difere muito das brancas superfícies que tanto causaram impressão no
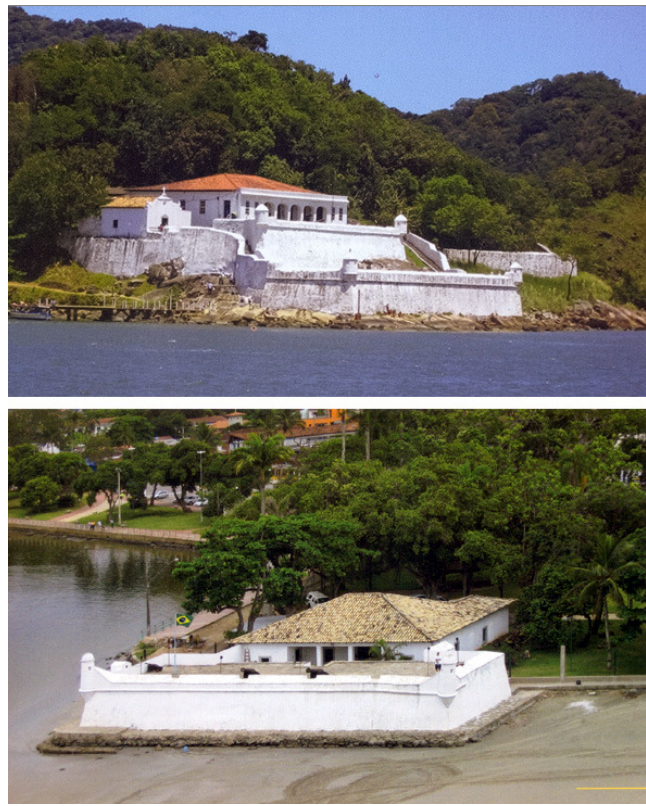

Fig. 40/41 - Fortes da Barra Grande e São João, após restauro. Fonte: LEMOS et alli, 2008, pp. 128 e 81 arquiteto modernista Vilanova Artigas ao contemplar a recém-restaurada Igreja de Nossa Senhora do Rosário, em Embu. ${ }^{65}$ Nessas como em outras tantas intervenções em edificações e conjuntos históricos no Brasil (e não só aqui, deve-se frisar), parece haver uma dificuldade em aceitar a idade dos monumentos, que, restaurados, devem ostentar 0 aspecto de novos. ${ }^{66}$ Como adverte Beatriz Kühl:

Sinais de transcurso do tempo são cada vez menos apreciados em nossa sociedade. Com essa tendência atual à renovação e à pasteurização de superfícies, muito se perde da riqueza e da vibração resultantes dos próprios métodos de execução tradicionais de argamassas e de pinturas e dos "acidentes" da vida de uma obra. ${ }^{67}$

Certamente, no caso dos fortes, expostos à ação da maresia e aos muitos anos de abandono, as patologias nas superfícies parietais eram problema de complexa e delicada resolução, porém o que se questiona aqui, baseado não apenas na leitura da intervenção nessas edificações isoladamente, como também em outros exemplos, ao que parece nem se cogitou a possibilidade de tratamento e consolidação das superfícies, visando manter suas características originais e a

${ }^{65}$ A Igreja de Nossa Senhora do Rosário e residência anexa figura entre os primeiros bens do estado de São Paulo a ser incluído nos livros de tombo do IPHAN. Foi restaurada entre os anos 1939-1940. Ao visitar o monumento, Artigas manifestou sua admiração diante do que the pareceu "a mais veemente afirmação dos cânones da Arquitetura Moderna”. Cf.: ANDRADE, Antonio Luiz Dias de. Op. cit., pp. 127.

${ }^{66}$ Alois Riegl, em sua obra "O culto moderno dos monumentos", de 1903, já tratava dificuldade de aceitação do aspecto vetusto dos monumentos, chamado por ele de "valor de novidade", isto é, quando se espera do monumento a aparência nova e fresca de uma obra recém-criada, do que decorre uma forte tendência repristinatória e de refazimento em detrimento de um verdadeiro restauro, mesmo nos casos em que há o reconhecimento de que sejam monumentos de grande importância para a história da arquitetura (RIEGL, Aloïs. Le culte..., op. cit., pp. 96). Também com relação à intolerância pelas marcas do tempo nos monumentos, ver o artigo: CUNHA, Claudia dos Reis; KODAIRA, Karina Terumi. "O legado moderno na cidade contemporânea: restauração e uso", In: Anais do 8온 Seminário DOCOMOMO Brasil, Rio de Janeiro, 2009, cd-rom.

${ }^{67} \mathrm{KÜHL}$, Beatriz Mugayar. "O tratamento das superfícies arquitetônicas como problema teórico da restauração", In: Anais do Museu Paulista, v. 12, jan.-dez. 2004, pp. 322. 


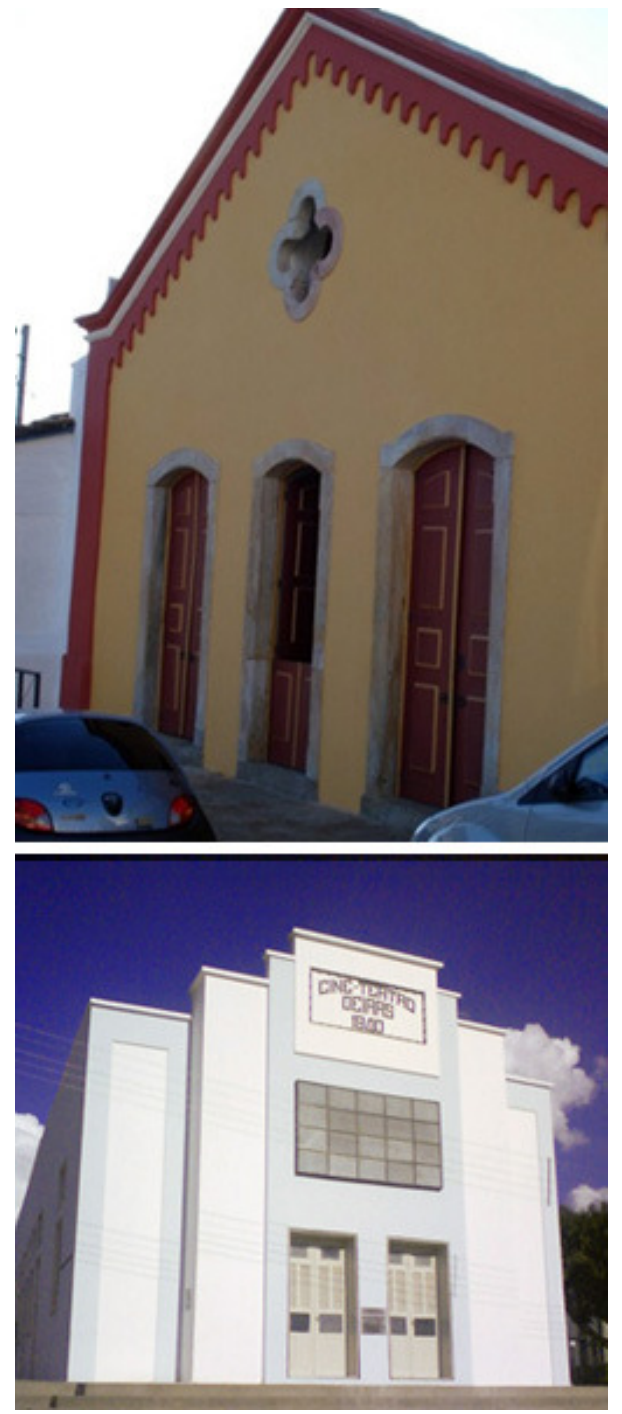

Fig. 42/43 - Ouro Preto, antiga Casa de Ópera, atual Teatro Municipal. Oeiras, Cine-teatro. Destaque para a total repintura das fachadas. Fonte: www.monumenta.gov.br. pátina. ${ }^{68}$ Fato que se reproduz também nos casos de intervenção vinculados ao Programa Monumenta (Fig. 42/43), tais como se poderá observar no conjunto de ações implementadas a partir de 1998 no Bairro do Recife, marco zero da capital pernambucana.

$$
\text { O tombamento do Conjunto Arquitetônico, }
$$

Urbanístico e Paisagístico do Antigo Bairro do Recife pelo IPHAN, em 1998, ${ }^{69}$ inscrito no Livro de Belas Artes e também no Arqueológico, Etnográfico e Paisagístico, tem como uma das justificativas o fato de o bairro ser "o único remanescente íntegro completo no Brasil do pensamento urbano e arquitetônico da 'belle époque' no Brasil". ${ }^{70}$ Fruto de uma ampla reforma urbana executada em 1910, responsável pela destruição ou descaracterização de remanescentes coloniais ou do período de dominação holandesa, o aspecto eclético do bairro em outros tempos seria um contundente motivo para desqualificar o pedido de tombamento apresentado pela Prefeitura da cidade. A segunda justificativa parece ainda mais estranha às práticas "tradicionais" de tombamento do Patrimônio Nacional: o bairro deveria ser tombado também "pela diversidade dos estilos arquitetônicos e padrões

68 A preservação da pátina foi um dos aspectos pelos quais Brandi se debateu fortemente. Um dos exemplos é a polêmica em torno da limpeza radical de pinturas feita pela National Gallery de Londres. Respondendo à proposição dos ingleses de que "[...] permanece presumível, acima de qualquer discussão, que o objetivo de quem se deve ocupar da conservação e da restauração das pinturas é o de apresentá-las o máximo possivel no estado em que o artista queria que fossem vistas", o autor afirma tratar-se da "suposição mais insidiosa que se possa formular. Nem um conservador, nem um restaurador pode supor isso, justamente porque é uma suposição, uma suposição indemonstrável: a de poder remontar a um suposto aspecto originário cujo único testemunho válido seria a obra quando foi completada, ou seja, sem a passagem pelo tempo, ou seja, um absurdo histórico. Mas é precisamente a esse objetivo cego que tende a limpeza integral: tratar uma obra de arte como se esta estivesse fora da arte e da história e que pudesse ser reversivel no tempo [...]. É por isso que o conceito de pátina, longe de se confinar em uma fabulação romântica, se foi refinando em um conceito que tem a intenção de respeitar as razões da arte e da história [...]". BRANDI, Cesare. Op. cit., pp. 172-173. Grifos do autor.

69 Processo no 1168-T-85. Fonte: Base de dados digital do Arquivo Noronha Santos (http://www.iphan.gov.br/ans/inicial.htm).

70 "Revitalização do Bairro do Recife - Proposta de Tombamento do núcleo original da cidade do Recife", apud: LEITE, Rogério Proença. Op. cit., pp. 26. 
urbanos resultantes da reforma e seus impactos sobre as transformações urbanas remanescentes" ${ }^{71}$ Tradicionalmente, a preservação de núcleos urbanos ou de centros históricos através do tombamento em nível federal tem como parâmetro justamente o elemento que falta ao Bairro do Recife: a uniformidade, seja urbanística, seja arquitetônica. ${ }^{72}$ Porém, como alega Rogério Proença, "o tombamento foi um ato explicitamente político para atender a uma exigência do $B I D "{ }^{73}$ isto é, somente com a inclusão do centro histórico do Recife nos livros de tombo do IPHAN franqueou-se a participação da cidade no Programa

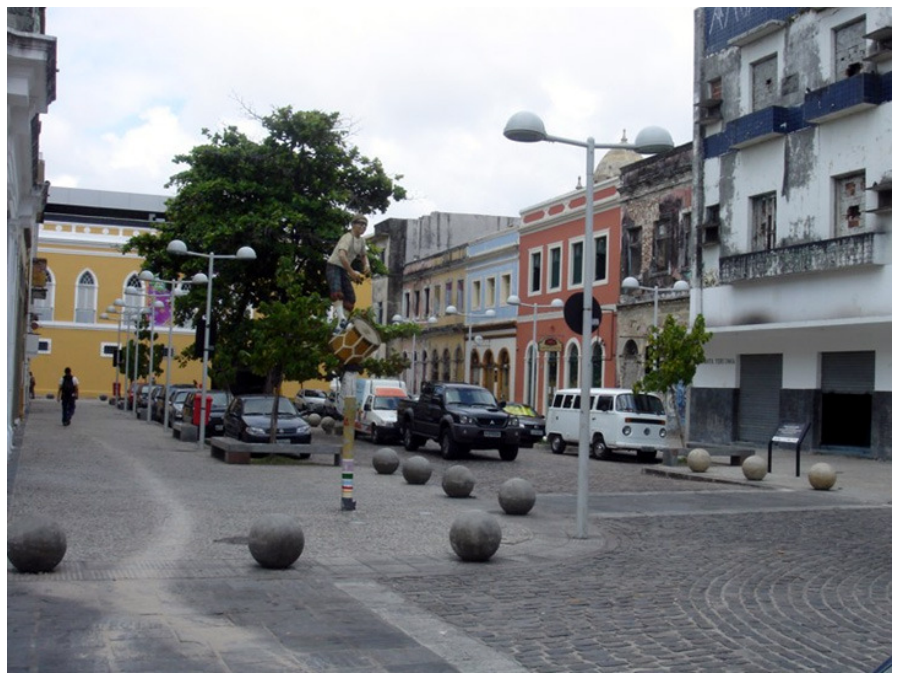

Fig. 44 - Recife, Rua da Moeda, com casario pintado pelo "Cores da Cidade" e reurbanização do Monumenta. Fonte: www.monumenta.gov.br. Monumenta, visto que até aquele momento, a igreja Madre de Deus era o único bem tombado pelo IPHAN no bairro, o que foi considerado "muito pouco" pelo BID, financiador do programa. $^{74}$

No intrincado modelo de intervenções em áreas históricas dos dias atuais, no qual as diferentes instâncias de governo se somam às grandes empresas e contam com 0 patrocínio de bancos de desenvolvimento, tais como o BID e o BNDES, o histórico das obras de revitalização no bairro do Recife são anteriores à aprovação do convênio com o Monumenta. Mesmo assim, os objetivos e as formas de intervenção são equiparáveis, reproduzindo o programa de embelezamento e enobrecimento do lugar, que passaria a ser propício ao consumo e ao turismo, por oposição ao cenário de degradação social e ambiental anterior à ação, tal como especificado no detalhamento técnico do Plano de Revitalização do Bairro do Recife, criado em 1992, cujos três principais objetivos eram:

1) transformar o Bairro do Recife em um "centro metropolitano regional", tornando-o um pólo de serviços modernos, cultura e lazer;

\footnotetext{
71 Idem, pp. 82.

72 Como atestam as cidades históricas mineiras, cujo tombamento se ampara na harmonia do conjunto barroco. Ver: LEITE, Rogério Proença. Op. cit., pp. 84.

73 Idem, pp. 90.

74 Idem, ibidem.
} 
2) tornar o bairro um "espaço de lazer e diversão", objetivando criar um "espaço que promova a concentração de pessoas nas áreas públicas criando um espetáculo urbano";

3) tornar o bairro um "centro de atração turística nacional e internacional". ${ }^{75}$

Estes objetivos, mais econômicos do que propriamente de restauração do patrimônio, coloca a cidade de Recife em total sintonia com os objetivos do

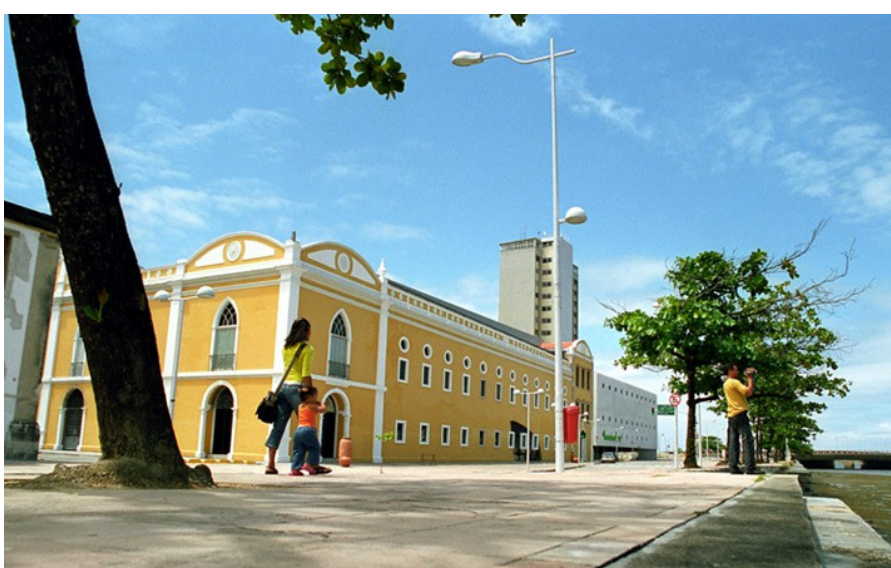

Fig. 45 - Recife, Rua da Alfândega após reurbanização. A antiga alfândega foi transformada em centro comercial.

Fonte: www.monumenta.gov.br.

Programa Monumenta, ${ }^{76}$ o qual, ao estabelecer a parceria com a cidade, prossegue dentro da mesma lógica.

A área delimitada para atuação do Monumenta no Bairro do Recife é o chamado Pólo Alfâdega/Madre de Deus, um dos cinco sub-grupos do núcleo original de formação da cidade. $^{77}$ Nessa área foram feitas intervenções em monumentos isolados, como é o caso da Igreja Madre de Deus, do antigo seminário oratoriano (depois Alfândega) ou do Edifcío Chanteclair, e também visando à recuperação do espaço urbano, através da reurbanização das ruas Madre de Deus, Vigário Tenório, da Alfândega (Fig. 45), Aluísio Magalhães, Aluísio Periquito, da Moeda (Fig. 44$)^{78}$ e trecho da Avenida Alfredo Lisboa, com a implantação de

${ }^{75}$ Plano de Revitalização - Bairro do Recife. Planejamento Urbano e Economia. Apud: LEITE, Rogério Proença. Op. cit., pp. 181.

${ }^{76}$ De fato, os dados de retorno dos investimentos efetuados até aquele momento na área foram fator apreciado pelo BID, tal como esclarece Norma Lacerda: "Ainda nesse ano [1995], O BID encomendou uma pesquisa [...] sobre o Desempenho do Plano de Revitalização do Bairro do Recife (Zancheti \& Lacerda, 1998). A pesquisa foi concluída salientando o êxito do projeto. Os investimentos em recuperação de imóveis ultrapassavam os limites do Pólo Bom Jesus, e a participação do setor privado, em termos do montante de recursos financeiros, correspondeu, aproximadamente, à mesma quantia investida pelo setor público" (LACERDA, Norma. "Intervenções no Bairro do Recife e no seu entorno: indagações sobre a sua legitimidade", In: Sociedade e Estado, Brasília, v. 22, n. 3, set./dez. 2007, pp. 629).

${ }^{77}$ No âmbito do Plano de Revitalização do Bairro do Recife, a área foi dividida em três setores: de consolidação urbana, de intervenção controlada e de renovação. Esses três setores, por sua vez, foram subdivididos em pólos de interesse, sendo o Pólo Fluvial alocado dentro do setor de consolidação urbana; os pólos Bom Jesus, Alfândega e Arrecifes conformando o setor de intervenção controlada; e, finalmente, o Pólo Pilar definido dentro do setor de renovação. Cf.: Plano de Revitalização - Bairro do Recife. Planejamento Urbano e Economia. Apud: LEITE, Rogério Proença. Op. cit., pp. 177.

${ }^{78}$ A Rua da Moeda, uma das atendidas pela reurbanização, já havia sido alvo em 1993do projeto "Cores da Cidade", uma parceria entre a Fundação Roberto Marinho e a 
sinalização, renovação do mobiliário urbano e recuperação de pavimentos. As obras de recuperação dos edifícios foram compartilhadas entre o Monumenta e a iniciativa privada, todas com financiamento do BID, sendo a restauração da igreja Madre de Deus atribuição exclusiva do Programa, a reabilitação ${ }^{79}$ do edifício da Alfândega e sua transformação em centro comercial feita pela

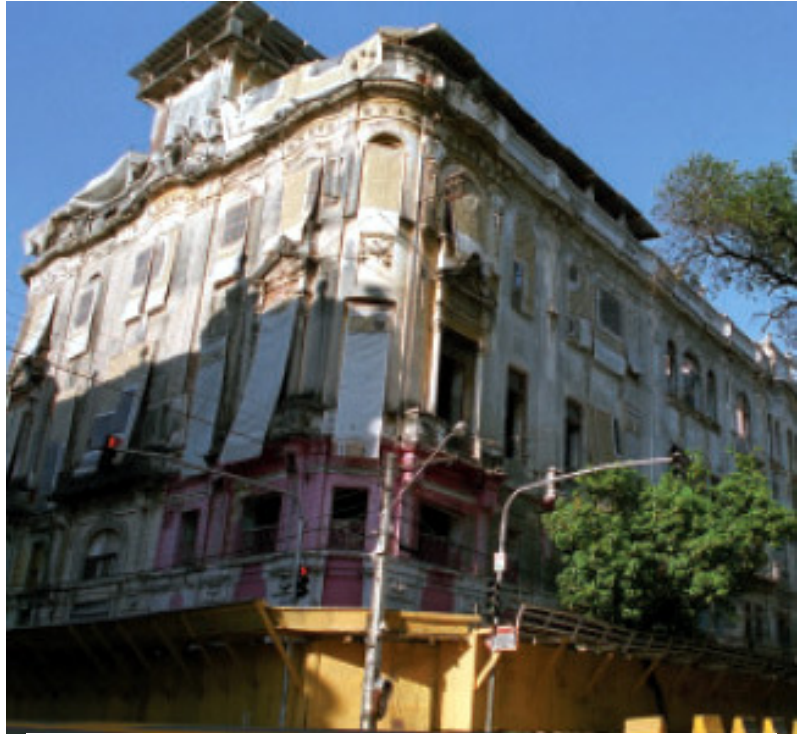

Fig. 46 - Recife, edifício Chanteclaire. Desapropriado e desocupado para receber as obras de reabilitação e tornarse centro de entretenimento. Fonte: www.monumenta.gov.br. iniciativa privada e a do Chanteclaire (Fig. 46), transformado em centro de entretenimento, com a parceria público-privada.

As obras de reabilitação da Alfândega e do Chanteclaire podem ilustrar bem o foco central da intervenção: a adoção de novos usos que possam tornar "sustentável" 0 investimento ali feito transformam-se na finalidade da ação e não em um meio para a preservação do patrimônio, o que seria recomendável. ${ }^{80}$ Conforme coloca Márcia Sant'Anna, 0 que rege 0 conjunto das intervenções atualmente é

[...] uma concepção de patrimônio urbano de caráter fachadista e concentrado em poucos elementos arquitetônicos. Essa concepção foi favorecida pela lógica financeira e promocional que presidiu a montagem e a execução da maioria das operações e pelo vínculo dessas ações com o entretenimento, com o lazer cultural e com o turismo de espetáculos. Decorre ainda de uma falta generalizada de compromisso com o papel informativo, documental e social do patrimônio. 81

empresa Akzo do Brasil (Tintas Ypiranga), visando a pintura das fachadas das edificações.

${ }^{79}$ Segundo o glossário de termos do "Manual de Elaboração de Projetos de Preservação do Patrimônio Cultural", reabilitação é o "conjunto de operações destinadas a tornar apto o edifício a novos usos, diferente para o qual foi concebido". Ver: BRASIL. Ministério da Cultura. Instituto do Programa Monumenta. Manual de elaboração de projetos de preservação do patrimônio cultural. Brasília: Ministério da Cultura, Instituto do Programa Monumenta, 2005, pp. 13.

$80 \mathrm{Na}$ Carta de Veneza, em seu artigo $5^{\circ}$, consta a seguinte recomendação com relação às novas possíveis utilizações de monumentos históricos: "A conservação dos monumentos é sempre favorecida por sua destinação a uma função útil à sociedade; tal destinação é, portanto, desejável, mas não pode nem deve alterar a disposição ou a decoração dos edifícios. É somente dentro desses limites que se devem conceber e se podem autorizar as modificações exigidas pela evolução dos usos e costumes" (Carta de Veneza, in: Cartas Patrimoniais, op. cit., pp. 93. Grifos nossos).

${ }^{11}$ SANT'ANNA, Márcia. "A cidade-atração. Patrimônio e valorização de áreas centrais no Brasil dos anos 90", In: FERNANDES, Ana; JACQUES, Paola Berenstein (orgs.). Cadernos PPG-AU/FAUFBA - Territórios urbanos e políticas culturais. Salvador: PPGAU/FAUFBA, número especial, ano 2, 2004, pp. 52. 
Ainda que um dos componentes de ação do Monumenta seja justamente a conscientização do valor que o patrimônio tem e da importância da participação das comunidades nas tarefas da preservação, através de oficinas, vídeos e publicações com o foco na educação patrimonial, ${ }^{82}$ o público-alvo dos espaços revitalizados, identificados como potenciais consumidores e freqüentadores de bares, restaurantes e espaços culturais, é extremamente restritivo, excluindo a maior parte da população que anteriormente tinha vínculos com o lugar.

Outra questão a ser colocada diz respeito ao descomprometimento com a realidade histórica e matérica do bem cultural. Ainda que em seu "Manual de Elaboração de Projetos de Preservação do Patrimônio Cultural", seja claramente estabelecida como premissa o respeito aos "valores estéticos e culturais do Bem, com o mínimo de interferência na autenticidade do mesmo, seja autenticidade estética, histórica, dos materiais, dos processos construtivos, do espaço envolvente ou outras", afirmando ser "fundamental o conhecimento dos documentos internacionais e dos princípios enunciados nas cartas patrimoniais para elaboração de Projetos de Preservação" ${ }^{83}$ seja nas obras sob encargo direto do Monumenta, seja naquelas por ele aprovadas e supervisionadas, 0 contraste com essas indicações é flagrante. No caso do Bairro do Recife, a transformação do antigo seminário oratoriano, ainda que já bastante danificado pelos sucessivos usos por que passou, em centro comercial - o Shopping Paço Alfândega -, com a construção de duas torres de estacionamento ao lado do edifício (projetadas pelo arquiteto paulistano Paulo Mendes da Rocha), pode ser exemplo de como as necessidades de dinamizar os negócios e viabilizá-los do ponto de vista econômico, deixam as questões culturais em segundo plano, contrariando mais uma vez a indicação do "Manual de Projetos", que afirma: "é premissa para a preservação de um Bem usos compatíveis com a vocação do mesmo" ${ }^{84}$ Mesmo quando se trata da atribuição de um "uso cultural" para uma edificação histórica, a exemplo do ocorrido com o Chanteclaire, a visão de cultura adotada na intervenção é identificada apenas como cultura de consumo ou consumo cultural e não com uma noção mais ampla, vinculada com a

82 BRASIL. Regulamento Operativo..., op. cit., pp. 14.

83 BRASIL. Ministério da Cultura. Instituto do Programa Monumenta. Manual de elaboração..., op. cit., pp. 15 e 16.

84 Idem, pp. 16. 
manutenção da diversidade e das manifestações do cotidiano relacionadas ao monumento.

O Bairro do Recife foi uma das iniciativas pioneiras do Programa Monumenta, que nesse primeiro período atingiu apenas 7 cidades brasileiras, ${ }^{85}$ escolhidas por serem "representativas das problemáticas de conservação existentes no país, englobando sistemas urbanos degradados, cidades médias tombadas e conjuntos de monumentos em centros metropolitanos" ${ }^{86}$ Porém, mesmo com projetos ainda em fase de implantação e, portanto, sem concretos instrumentos de análise dos resultados, o Programa estendeu-se para mais 20 cidades. Em 2006 o Coordenador Nacional do Programa Monumenta, arquiteto Luiz Fernando de Almeida, é nomeado presidente do IPHAN e a estrutura administrativa do Programa se incorpora ao Instituto. Nesse mesmo ano, iniciamse as discussões sobre a absorção definitiva dos aportes conceituais e gerenciais trazidos pelo Monumenta à estrutura permanente do governo. A adesão ao Programa alcança hoje 26 municípios, mas um seminário realizado em Mariana/MG, com a participação de prefeitos de 87 cidades históricas, discute uma nova ampliação na área de atuação do Monumenta e promover sua continuidade a longo prazo. ${ }^{87}$

Mesmo que com a incorporação do Monumenta ao IPHAN o órgão federal de preservação tenha ganho mais destaque e talvez até recuperado um pouco de seu prestígio junto à opinião pública, a fórmula preservacionista prevalente continua a ser aquela dada pelo setor econômico e de negócios, superposto aos interesses culturais, os quais deveriam ter preeminência absoluta quando se trata da preservação do patrimônio cultural.

Apesar da inegável atualização que é a inclusão dos bens de natureza intangível na esfera das práticas de preservação brasileiras, no que se refere aos monumentos "tradicionais" - arquitetônicos e áreas urbanas - nada de novo existe. Ao contrário, mantêm-se fórmulas de atuação bastante conservadoras, em alguns casos até mesmo antiquadas, repetindo (embora agora de modo não tão homogêneo ou unânime) velhas formas de tratamento, praticadas pelos

\footnotetext{
${ }^{85}$ Recife, Olinda, Ouro Preto, Rio de Janeiro, São Paulo, Salvador e São Luís.

${ }^{86}$ SANT'ANNA, Márcia. A cidade-atração..., op, cit., pp. 260.

87 Cf.: Histórico do Programa, disponível em: http://www.monumenta.gov.br/site/?page id=165. Acesso em: 29 jan. 2009, 10:42.
} 
herdeiros da velha "Academia SPHAN" ${ }^{88}$ A leitura dos monumentos, apesar do discurso mais amplo de patrimônio que se propala, continua a ser feita a partir de suas características estéticas. Mas a leitura estética que se faz agora é ainda mais rasa do que aquela da fase heróica, resumida à aparência exterior do monumento, que deve ostentar cores chamativas e alegres, num quadro de apropriação consumista e vazio daquilo que deveria ser a materialização da memória coletiva.

A facilidade de comunicação dos dias atuais e mesmo a participação do Brasil em organizações internacionais de proteção aos monumentos tornaram 0 acesso aos debates sobre o tema extremamente mais fácil e agilizado. Os conteúdos de cartas e outras recomendações internacionais para a salvaguarda dos bens culturais são de amplo conhecimento daqueles que lidam com o tema $\mathrm{e}$ até mesmo de um público mais amplo, favorecido pela difusão de publicações no mercado editorial brasileiro. Também as diversas vertentes teóricas contemporâneas da restauração são conhecidas, juntamente com textos canônicos da disciplina, como pode ser visto nas referências feitas em memoriais de projeto e outros textos divulgados em anais de seminários, revistas e outras publicações do ramo. Porém, a despeito deste conhecimento e mesmo do compromisso que o Brasil tem como país-membro da Convenção do Patrimônio Mundial ou do ICOMOS, por exemplo, a análise das práticas de restauro leva à inequívoca consciência da distância estabelecida entre a verdadeira restauração e as muitas intervenções em bens de interesse cultural implementadas sob supervisão e com a aprovação do IPHAN匹

${ }^{88}$ Expressão de Mariza Veloso Santos. Ver: SANTOS, Mariza Veloso Motta. "Nasce a Academia...", op. cit., pp. 78. 


\title{
-CONSIDERAÇÕES FINAIS
}

\begin{abstract}
Não se pode pretender que o ambiente da vida contemporânea permaneça idêntico ao do passado (além do mais, de que passado?), nem tampouco que se bloqueie 0 processo natural de envelhecimento e desagregação das coisas. Por isso, a determinação das relações complexas entre $o$ antigo e o moderno deve basear-se em metodologias críticas claras, ainda que não necessariamente idênticas. $A$ proteção dos patrimônios culturais deve certamente ser conservacionista, mas não conservadora. Giulio Carlo Argan [A arte no contexto da cultura moderna, 1979]
\end{abstract}

A noção de restauro é ainda bastante confusa no Brasil, embora se fale muito sobre 0 assunto em virtude do grande interesse que as práticas de preservação do patrimônio têm alcançado por aqui. Pode-se ler e ouvir as mais diferentes definições, mas, quase sempre, restauração rima com reconstrução e com retorno ao estado (pretensamente) originário do bem sobre 0 qual recai a ação.

Ao longo de todo o primeiro capítulo procurou-se evidenciar que, de fato, o conceito de restauro não é simples e sua definição não pode ser dada de uma vez por todas, posto se tratar de um fenômeno relativamente recente, cujas origens remontam ao século XVIII, mas que se consolida como capo disciplinar autônomo somente em finais do século XIX e início do XX.

De meados do século XIX são algumas das definições mais conhecidas do que venha a ser restauro. Dentre elas, alcançou grande fortuna crítica 0 conceito de restauração estabelecido pelo francês Viollet-le-Duc: "restaurar um edifício [...] é restabelecê-lo em um estado completo que pode não ter existido nunca em um dado momento". ${ }^{1}$ De outra parte, o anticonceito defendido pelo inglês John Ruskin também alcançou notoriedade, ao afirmar que a restauração "significa a mais total destruição que um edifício pode sofrer". ${ }^{2}$ Essas definições lançadas em finais do século XIX, juntamente com a noção de monumento histórico que as sustentavam, foram sendo lentamente amadurecidas e reelaboradas, até que em meados do século XX surge outra definição igualmente célebre, a do italiano Cesare Brandi, que estabelece a restauração

1 VIOLLET-LE-DUC, Eugène Emmanuel. Op. cit., pp. 29.

${ }^{2}$ RUSKIN, John. Op. cit., pp. 79. 
como "momento metodológico do reconhecimento da obra de arte, na sua consistência física e na sua dúplice polaridade estética e histórica, com vistas à sua transmissão para o futuro".3

Muitas reuniões internacionais foram realizadas com o objetivo de discutir princípios e critérios de intervenção, culminando com a edição de diversas cartas de recomendações nas quais se reconhece "a importância que representa, para todos os povos do mundo, a salvaguarda desses bens singulares e insubstituíveis, qualquer que seja o povo a que pertençam". ${ }^{4}$ Dessa forma, buscou-se o estabelecimento de princípios visando "à conservação e à restauração dos monumentos [...] elaborados em comum e formulados num plano internacional, ainda que caiba a cada nação aplicá-los no contexto de sua própria cultura e de suas tradições" ${ }^{5}$

No Brasil, as práticas de preservação, aqui incluídas a tutela legal e também as ações de conservação e restauro do patrimônio nacional, se afirmam na segunda metade da década de 1930, após anos de debates intensos. Em 1936 começa a funcionar em bases provisórias o então Serviço do Patrimônio Histórico e Artístico Nacional - SPHAN, incumbido de inventariar e preservar o acervo de bens móveis e imóveis considerados de excepcional valor para a cultura brasileira. No segundo capítulo deste trabalho viu-se que tais práticas de preservação eram implementadas ora em consonância com os princípios teóricos do restauro, ora em desacordo com eles. Ao longo da chamada "fase heróica" do SPHAN, juntamente com a proeminência dos arquitetos dentre os técnicos da instituição, prevaleceram soluções oriundas do campo da arquitetura, seja no que se refere aos critérios de seleção de bens a serem tombados, seja no partido e método adotados nas obras de restauração e conservação. Não se pensava nos problemas a serem enfrentados como afeitos ao campo da restauração, mas como questão de arquitetura. 0 comprometimento com os preceitos da Carta de Atenas de Restauração (1931), à qual Rodrigo Melo Franco fazia alusão, cedia lugar aos conceitos emanados da Carta de Atenas do CIAM (1933), buscando equacionar a preservação do passado com a construção do futuro. Retomando Luís Saia, lembra-se aqui que

\footnotetext{
${ }^{3}$ BRANDI, Cesare. Op. cit., pp. 30.

4 Convenção sobre a salvaguarda do patrimônio mundial, cultural e natural (1972), In: Cartas Patrimoniais, op. cit., pp. 178.

${ }^{5}$ Carta de Veneza (1964), In: Cartas Patrimoniais, op. cit., pp. 91.
} 
Os 35 anos de experiência do IPHAN contaram com a participação de arquitetos brasileiros que não possuíam nenhuma formação especializada em restauração, mas cujo conhecimento da arquitetura, permanentemente atualizados pelo estudo do tradicional e do contemporâneo, conduziu este trabalho a um nível de profundo respeito pelos documentos do passado [...]. $]^{6}$

Como demonstrado no terceiro capítulo, a necessidade dessa formação especializada na área da restauração só foi sentida por volta dos anos 1970, durante a gestão de Renato Soeiro, em conseqüência da crise de legitimidade por que passa o IPHAN, considerado elitista e distante dos anseios da sociedade brasileira. Essa década marca profundas mudanças na forma de compreensão do que seja patrimônio e de seu papel na sociedade de massas. A conciliação entre a preservação do passado e das tradições com desenvolvimento e modernidade, a que se referia Luís Saia, passa a ser equacionada em novas bases, calcada a partir de então na valorização e exploração turística dos bens culturais. Os anos 1970 representam também a descentralização das políticas de preservação no Brasil, que deixam de ser atribuição exclusiva do IPHAN com a criação de órgãos estaduais congêneres, além da inclusão de novos programas no discurso preservacionista federal após a criação do sistema SPHAN/PróMemória.

Ainda que não sem controvérsias e resistência por parte dos antigos funcionários da casa, a inclusão de bens de tipologias mais diversificadas e de épocas mais recentes no quadro dos tombamentos efetuados pelo IPHAN em sua fase moderna foi efetiva. Porém, ainda mais difícil do que a incorporação dos novos programas nos critérios de seleção daquilo que seria tombado, foi a revisão nos conceitos de restauro até então adotados. Se a partir dos anos 1980 a noção de valor histórico e de sítio urbano passa a ser realmente priorizada nos critérios de seleção dos bens a serem tombados no Brasil, esse fato não alterou grandemente a forma "clássica" de intervenção: a prática de reconstruções no "estilo patrimônio" conservou-se inalterada, procurando coibir, com a adoção de cartilhas e manuais de intervenção, as mudanças "descaracterizadoras" dos conjuntos, sendo a experiência de recuperação e revitalização do centro histórico de Olinda uma exceção que não se tornou regra. Igualmente no caso de edificações isoladas, as freqüentes referências à Carta de Veneza (1964), dando ensejo ao respeito pelas diversas etapas por que passou o monumento e no abandono da busca pela unidade estilística, não redundou numa total renovação

${ }^{6}$ SAIA, Luís. "Até os 35 anos...", op. cit., pp. 16. 
no campo das restaurações, que continuaram a privilegiar uma leitura estéticoformal dos monumentos, relegando a preservação da autenticidade material e histórica para segundo plano.

No último capítulo foi mostrada a grande inovação representada pelo Programa Nacional de Patrimônio Imaterial, que complementa a ação preservacionista brasileira, antes muito focada no tombamento, instrumento jurídico inadequado aos bens de natureza intangível, reconhecidos pela Constituição de 1988 como integrantes da riqueza cultural da nação. Por outro lado, a questão da proteção dos bens materiais e, especialmente, imóveis passa a ser tratada quase que exclusivamente pelo setor econômico e de negócios, acirrando tendências que já se insinuavam desde os anos 1970. Paralelamente à instalação do Programa Monumenta assiste-se a uma multiplicação dos nomes e métodos de intervenção operados sobre edifícios e sítios urbanos históricos: revitalização, reciclagem, renovação, reabilitação, retrofit, etc. Todas essas ações superpõem os interesses econômicos àqueles de natureza verdadeiramente cultural, agindo de modo irrefletido e pouco comprometido com as características físicas do bem cultural, deslocando por completo os objetivos de um verdadeiro restauro.

Atualmente, o que se vê no âmbito das teorias da restauração é um trabalho de rearranjo conceitual, que se dá a partir daquilo que foi sendo paulatinamente estabelecido como princípios válidos e idôneos para a preservação dos bens culturais. Ainda que haja diversas tendências teóricas, é consenso que nenhuma intervenção em bens de reconhecido valor cultural que tenha caráter utilitarista, de promoção política ou ainda de exploração econômica pode ser considerada restauro. Tais ações transcuram por completo o objetivo primeiro que deveria nortear qualquer intervenção em bens culturais, qual seja, conservar e transmitir ao futuro o legado do passado. Uma verdadeira restauração está sempre comprometida primeiramente com a conservação do bem cultural de modo íntegro, seja no que respeita a sua autenticidade material, seja como documento histórico, restringindo-se a fazer o mínimo necessário. 0 que não significa de modo algum se abster de agir quando seja efetivamente necessário, mas sempre no respeito das características e do caráter do monumento, sem usá-lo como mote para a autopromoção e sem sacrificar sua autenticidade material em nome de uma modernização a todo custo. 
Analisando as mais de sete décadas de atuação do IPHAN fica patente que, desde sua criação nos anos 1930, o órgão sempre esteve a par das tendências e critérios operativos do campo da restauração, inclusive mais recentemente participando diretamente das discussões que redundaram em algumas das mais importantes recomendações internacionais sobre 0 tema, a exemplo da Carta de Veneza (1964). Portanto, o discurso das "idéias fora do lugar" efetivamente não cabe aqui.

Todavia, apesar do conhecimento desses instrumentos teóricos, nota-se um certo descomprometimento com a discussão e a incorporação desses conhecimentos à prática institucional, na qual o restauro é quase sempre entendido como problema arquitetônico, de natureza técnica, portanto, e, mais recentemente, como questão econômica, ligada ao desenvolvimento do lugar. Nesse cenário, a discussão de princípios teóricos parece desnecessária ou pouco pertinente à prática, porém,

Anche quando si ha la pretesa di negarla, la teoria è implicita in ogni indirizzo operativo che si sostiene e si applica, poiché a monte di ogni attività pratica ci si imbatte con la riflessione sugli scopi, sugli strumenti e sulle procedure che si ritengono indispensabili e più idonei alle necessità, quindi con il metodo. ${ }^{7}$

Longe de serem elucubrações estéreis, as teorias da restauração, quando aplicadas às intervenções em arquiteturas e áreas urbanas históricas, assim como em qualquer outro bem cujo valor cultural tenha sido reconhecido por uma dada sociedade, oferecem consistência e credibilidade à prática. Acredita-se que, justamente porque 0 restauro não é uma atividade exclusivamente técnica - ao contrário - requer sempre uma mediação crítica, não se pode prescindir da reflexão teórica, necessária como meio de controlar as intervenções, estabelecendo procedimentos mais uniformes e com resultados mais satisfatórios. A teoria não se confunde com manuais de ação ou regras fixas, são antes parâmetros de ação necessários ao bom fim de qualquer intervenção sobre bens de reconhecido valor cultural. Ainda que cada caso seja um caso particular não enquadrável em rígidos padrões, somente através da adoção de sólidos princípios teóricos a prática da restauração se torna consistente e socialmente responsável.

Como se procurou demonstrar ao longo de toda esta pesquisa, a adoção de referenciais teóricos na área da restauração não representa uma

${ }^{7}$ LA REGINA, Francesco. // restauro dell'architettura..., op. cit., pp. 65. 
atitude colonizada e sim o reconhecimento de que existem instrumentos que podem tornar a prática de intervenção em bens culturais mais eficaz e responsável. Negar a validade dos princípios teóricos do restauro apenas porque foram inicialmente estabelecidos na Europa significa o mesmo que não aceitar a historiografia, a medicina ou outra ciência qualquer, por serem "estrangeiras" e terem sua origem fora do Brasil. Claro está que algumas recomendações, como por exemplo a anastilose de monumentos da Antiguidade, não fazem sentido frente à realidade brasileira, porém, isto não invalida a abrangência das recomendações internacionais, que devem ser tomadas como referência e não como lei incontestável. Fundamental é a reflexão sobre os métodos e instrumentos mais adequados ao contexto brasileiro, agindo em consonância com a Carta de Veneza, que recomenda a adequação dos princípios gerais a cada cultura e tradição.

Diante da confusão que gira em torno do conceito de restauro no país, seria de grande valia a construção, através de ampla discussão, de uma Carta Brasileira de Restauro, na qual se pudesse estabelecer de forma clara o que é admissível e o que não é aceitável nesse campo de atuação. Não se trata de mais uma cartilha ou manual, tampouco de uma nova lei criada por um jurista e imposta a fórceps, mas de um instrumento coletivamente arquitetado e que contemple os elementos basilares sem o qual o restauro deixa de ser restauro 


\section{-REFERÊNCIAS BIBLIOGRÁFICAS}

ANDRADE, Antonio Luiz Dias de. Um Estado completo que pode jamais ter existido. São Paulo, FAU-USP, Tese de Doutorado, 1993.

ANDRADE, Manuella Marianna. A sociedade civil na gestão urbana do bairro do Recife. São Paulo, Faculdade de Arquitetura e Urbanismo, Universidade Presbiteriana Mackenzie, Dissertação de Mestrado, 2003.

ANDRADE, Mário. Mário de Andrade: cartas de trabalho. Correspondência com Rodrigo Melo Franco de Andrade, 1936-1945. Brasília: Fundação Nacional Pró-memória, 1981.

ANDRADE, Rodrigo M. F. de. Rodrigo e o SPHAN. Coletânea de textos sobre patrimônio cultural. Rio de Janeiro: Fundação Nacional Pró-memória, 1987.

ARGAN, Giulio Carlo. História arte como história da cidade. São Paulo: Martins Fontes, 1993.

BALDINI, Umberto. Teoria del restauro e unità di metodologia, vol. I. Firenze: Nardini, 10ª ed., 2003.

BELLINI, Amadeo (a cura di). Tecniche della conservazione. Milano: Franco Angeli, 1986.

BOITO, Camillo. Os Restauradores. São Paulo: Ateliê Editorial, 2002. Questioni pratiche di Belle Arti. Milano: Hoepli, 1893.

BONELLI, Renato. "Verbete: II Restauro Architettonico", In: Enciclopedia Universale dell'Arte. Novara, Istituto Geografico de Agostini, 4" ed., 1983, pp. 344-351.

. Scritti sul restauro e sulla critica architettonica. Roma: Bonsignori Editore, 1995.

BONELLI, Renato; DE ANGELIS D'OSSAT, Guglielmo. Due lezioni di restauro. Roma: Multigrafica Editrice, 1987.

BONSANTI, Giorgio. "Per una definizione di restauro", In: Kermes: la rivista del restauro, vol. 19, n. 62, aprile/giugno 2006, pp. 67-71.

BOSCARINO, Salvatore; CARBONARA, Giovanni; PASTOR, Valeriano; PIRAZZOLI, Nullo. Il progetto di restauro: interpretazione critica del testo architettonico. Trento: Comitato Giuseppe Gerola, 1988.

BOSCARINO, Salvatore. Sul restauro architettonico. Saggi e note a cura di Antonella Cangelosi e Renata Prescia. Milano: Franco Angeli, $7^{\underline{a}}$ ed., 2007. 
BOSI, Vera. "Núcleos históricos: recuperação e revitalização; a experiência de Olinda", In: Revista do Patrimônio Histórico e Artístico Nacional. Rio de Janeiro: SPHAN / Pró-Memória, n. 21, 1986, pp. 134-145.

. "Participação e pesquisa na preservação do patrimônio cultural", In: Revista do Patrimônio Histórico e Artístico Nacional. Rio de Janeiro: SPHAN / Pró-Memória, n. 22, 1987, pp. 138-144.

BOYER, M. Christine. The city of collective memory: its historical imagery and architectural entertainments. Cambridge / London, The MIT Press, 1996.

BRANDI, Cesare. Teoria da Restauração. Cotia-SP: Ateliê Editorial, 2004.

BRASIL. Decreto n. 335, de 11 de novembro de 1991. Dá nova redação ao Anexo I ao Decreto n. 99.602, de 13 de outubro de 1990, que aprova a Estrutura Regimental do Instituto Brasileiro do Patrimônio Cultural IBPC. Diário Oficial da União, Brasília, DF, 12 nov. 1991.

Decreto n. 99.602, de 13 de outubro de 1990. Aprova a Estrutura Regimental de Instituto Brasileiro do Patrimônio Cultural e dá outras providências. Diário Oficial da União, Brasília, DF, 15 out. 1990.

. Lei n. 7.505, de 02 de julho de 1986. Dispõe sobre benefícios fiscais na área do Imposto sobre a Renda concedidos a operações de caráter cultural ou artístico. Diário Oficial da União, Brasília, DF, 04 jul. 1986.

. Lei n. 8.029, de 12 de abril de 1990. Dispõe sobre a extinção e dissolução de entidades da administração Pública Federal. Diário Oficial da União, Brasília, DF, 13 abr. 1990.

Lei n. 8.313, de 23 de dezembro de 1991. Restabelece princípios da Lei $n^{\circ} 7.505$, de 2 de julho de 1986, institui o Programa Nacional de Apoio à Cultura (PRONAC) e dá outras providências. Diário Oficial da União, Brasília, DF, 24 dez. 1991.

. Ministério da Cultura. Instituto do Programa Monumenta. Manual de elaboração de projetos de preservação do patrimônio cultural. Brasília: Ministério da Cultura, Instituto do Programa Monumenta, 2005.

Regulamento Operativo do Programa de Preservação do Patrimônio Histórico Urbano - Monumenta. 1200/OC-BR, Versão setembro 2006, pp. 10.

CAMPANELLI, Alessandro Pergoli. "Restauro contemporâneo: algumas abordagens", In: Revista CPC, São Paulo, n. 7, nov. 2008/abr. 2009.

CAMPELLO, Glauco. "A restauração do Paço: revendo 240 anos de transformações", In: Revista do Patrimônio Histórico e Artístico Nacional. Rio de Janeiro: SPHAN / Pró-Memória, n. 20, 1984, pp. 139151.

CAPITEL, Antón. Metamorfosis de monumentos y teorías de la restauración. Madrid: Alianza Forma, 1992. 
CARBONARA, Giovanni. "Architettura e restauro oggi a confronto", In: Palladio, n. 35,2005 , pp. 99-128.

. "Brandi e a Restauração Arquitetônica Hoje", In: Desígnio - Revista de História da Arquitetura e do Urbanismo. São Paulo: FAUUSP / Annablume, n. 6, nov/2007, pp. 35-47.

. "Restauro fra conservazione e ripristino: note sui più attuali orientamenti di metodo", In: Palladio. Nuova Serie, n. 3, 1990, pp. 4376.

. Avvicinamento al restauro. Teoria, storia, monumenti. Napoli: Liguori Editore, 1997.

. La reintegrazione dell'imagine. Roma: Bulzoni, 1976.

Cartas Patrimoniais, Rio de Janeiro: IPHAN, $2^{2}$ ed., 2000.

CASIELLO, Stella (a cura di). La cultura del restauro. Teorie e fondatori. Venezia: Marsilio, $3^{\mathrm{a}}$ ed., 2005.

CASIELLO, Stella. Verso una storia del restauro. Dall'età classica al primo Ottocento. Firenze: Alinea, 2008.

CASTRIOTA, Leonardo Barci. Patrimônio cultural: conceitos, políticas, instrumentos. São Paulo: Annablume, Belo Horizonte: IEDS, 2009.

CASTRO, Sonia Rabello de. O Estado na preservação de bens culturais: 0 tombamento. Rio de Janeiro: Renovar, 1991.

CAVALCANTI, Lauro (org). Modernistas na repartição. Rio de Janeiro: UFRJ I IPHAN, 1993.

CAVALCANTI, Lauro. "O Quarteto Antropofágico: da redescoberta ao moderno e ao contemporâneo", In: CHAGAS, Mário (org.). Revista do Patrimônio Histórico e Artístico Nacional - Museus: antropofagia da memória e do patrimônio. Instituto do Patrimônio Histórico e Artístico Nacional, n. 31, 2005, pp. 58-73.

CESCHI, Carlo. Teoria e storia del restauro. (s.I.): Mario Bulzoni Editore, s.d.

CHOAY, Françoise. A Alegoria do Patrimônio. São Paulo: Ed. Unesp / Estação Liberdade, 2001.

CJ Arquitetura - 40 anos do Patrimônio Histórico, n. 17, 1977.

Coletânea de leis sobre Preservação do Patrimônio. Rio de Janeiro: IPHAN, 2006.

CORDARO, Michele. "Metodologia del restauro e progetto architettonico", In: Bollettino d'Arte, 1986, pp. 65-68.

"Restauro e tutela: scritti scelti (1969-1999)", In: Annali dell'Associazione Ranuccio Bianchi Bandinelli, n. 8, 2000. 
COSTA, Lucio. Documentos de Trabalho. Organizado por José Pessôa. Rio de Janeiro: IPHAN, 1999.

CRISTINELLI, Giuseppe \& FORAMITTI, Vittorio (a cura di). II restauro fra identità $e$ autenticità. Atti della tavola rotonda "I principi fondativi del restauro architettonico". Venezia: Marsilio, 2000.

CUNHA FILHO, Francisco Humberto. "Impactos da Constituição Federal de 1988 sobre o tombamento de bens do patrimônio cultural brasileiro", In: Anais do IV ENECULT - Encontro de Estudos Multidisciplinares em Cultura. Salvador, UFBa, 2008.

CUNHA, Claudia dos Reis e. "Alois Riegl e o 'Culto Moderno dos Monumentos", In: Revista CPC, São Paulo, v. 1, n. 2, maio/out. 2006, pp. 6-16.

. O patrimônio cultural da cidade de Sorocaba: análise de uma trajetória. São Paulo: FAU-USP, Dissertação de Mestrado, 2005.

CUNHA, Claudia dos Reis; KODAIRA, Karina Terumi. "O legado moderno na cidade contemporânea: restauração e uso", In: Anais do 8ํㅗㄹ Semário DOCOMOMO Brasil, Rio de Janeiro, 2009, cd-rom.

D'ASSUMPÇÃO, Livia Romanelli. Preservação urbana em Diamantina. Aspectos teóricos e a prática institucional (1938-1970). Salvador, FAU-UFBa, Dissertação de Mestrado, 1995.

DE FUSCO, Renato. Dov'era ma non com'era. II patrimonio architettonico e l'occupazione. Firenze: Alinea, 1999.

DEZZI BARDESCHI, Marco. "II restauro: una nuova definizione per un'antica (ambigua) disciplina", In: Ananke: cultura, storia e tecniche della conservazione, nuova serie, n. 41, 2004, pp. 2-5.

.Quarant'anni di restauri a Milano tra teorie e pratica", In: Ananke, n. 50-51, Firenze: Alinea Editrice, 2007, pp. 150-165.

Restauro: punto e da capo. Frammenti per una (impossibile) teoria. Milano: Franco Angeli, $7^{a} \stackrel{a}{e}$ ed., 2005.

DI BIASE, Carolina. "Camillo Boito", In: CASIELLO, Stella (a cura di). La cultura del restauro. Teorie e fondatori. Venezia: Marsilio, $3^{\mathrm{a}}$ edizione, 2005, pp. 159-181.

DOGLIONE, Francesco. Nel restauro. Progetti per le architetture del passato. Venezia: Marsilio / IUAV, 2008.

DVOŘÁK, Max. Catecismo da preservação de monumentos. Cotia-SP: Aletilê, 2008.

FEILDEN, Bernard M. Conservation of historic buildings. London: Butterworth Scientific, 1982.

FENERICH, Antônia Regina Luz. Preservação em São Paulo: análise de procedimentos metodológicos. São Paulo, FAUUSP, Dissertação de Mestrado, 2000. 
FERNANDES, Ana; JACQUES, Paola Berenstein (orgs.). Cadernos PPGAU/FAUFBA - Territórios urbanos e políticas culturais. Salvador: PPGAU/FAUFBA, número especial, ano 2, 2004.

FONSECA, Maria Cecília Londres. "Para além da pedra e cal: por uma concepção ampla de patrimônio cultural", In: ABREU, Regina \& CHAGAS, Mário (orgs). Memória e patrimônio: ensaios contemporâneos. Rio de Janeiro: Lamparina, 2ª ed., 2009, pp. 59-79.

. O Patrimônio em Processo. Rio de Janeiro, UFRJ / IPHAN, 1997.

GIOVANNONI, Gustavo. "Voce Restauro (Restauro dei monumenti)", In: Enciclopedia Italiana, Milano: Instituto della Enciclopedia Italiana (Treccani), v. 29, 1936, pp. 127-130.

. Vecchie città ed edilizia nuova. Torino: Utet, 1931.

GONÇALVES, Cristiane Souza. Restauração Arquitetônica. A experiência do SPHAN em São Paulo, 1937-1975. São Paulo: Annablume / Fapesp, 2007.

GONÇALVES, José Reginaldo Santos. A Retórica da Perda: os discursos do patrimônio cultural no Brasil. Rio de Janeiro: Ed. UFRJ / IPHAN, 1996.

GRASSI, Liliana. II restauro e il recupero creativo della memoria storica. A cura di Maria Antonieta Crippa e Emanuela Sorbo. Roma: Bonsignori, 2007.

HOBSBAWM, Eric \& RANGER, Terence (orgs.). A invenção das tradições. Rio de Janeiro: Paz e Terra, 1997.

JEUDY, Henri-Pierre. Espelho das cidades. Rio de Janeiro: Casa da Palavra, 2005.

JOKILEHTO, Jukka. "Preservation Theory Unfolding", In: Future Anterior. Volume III, Number 1, Summer 2006, pp. 1-9.

A History of Architectural Conservation. The contribution of English, French, German and Italian thought towards an international approach to the conservation of cultural property. D. Phil Thesis, Institute of Advanced Architectural Studies, The University of York, 1986.

KARA-JOSÉ, Beatriz. Políticas culturais e negócios urbanos. A instrumentalização da cultura na revitalização do centro de São Paulo (1975-2000). São Paulo: Annablume / Fapesp, 2007.

KIMMELMAN, Michael. "O futuro dos museus no século XXI", In: Jornal do Brasil. Rio de Janeiro, 11 set. 2001, pp. 08.

KÜHL, Beatriz Mugayar. "A restauração de monumentos históricos na França após a Revolução Francesa e durante o século XIX: um período crucial para o amadurecimento teórico", In: Revista CPC, São Paulo, n. 3 , nov. 2006/abr. 2007, pp. 110-144. 
"História e Ética na Conservação e na Restauração de Monumentos Históricos", In: Revista CPC, São Paulo, vol. 1, n. 1, nov. 2005/ abr. 2006, pp. 16-40.

"O problema da reprodução de obras arquitetônicas", In: Revista CPC, São Paulo, n. 7, nov. 2008/abr. 2009, pp. 127-136.

. "O tratamento das superfícies arquitetônicas como problema teórico da restauração", In: Anais do Museu Paulista, v. 12, jan.-dez. 2004, pp. 309-330.

"Restauração hoje: método, projeto e criatividade", In: Desígnio Revista de História da Arquitetura e do Urbanismo. São Paulo: FAUUSP / Annablume, n. 6, nov/2007, pp. 19-34.

Arquitetura do Ferro e Arquitetura Ferroviária em São Paulo. Reflexões sobre a sua preservação. São Paulo: Ateliê Editorial, 1998.

Preservação da Arquitetura Industrial em São Paulo: questões teóricas. São Paulo, FAUUSP, Relatório Científico (auxílio à pesquisa FAPESP), não publicado, jun. 2005.

LA REGINA, Francesco. "Architettura e 'coscienza del passato'. Appunti per uma ricerca sulle origini e sul significato del restauro moderno: l'antichità classica", In: CASIELLO, Stella (a cura di). Restauro dalla teoria alla prassi. Napoli: Electa Napoli, 2000, pp. 27-41.

"L'opera, l'attività, le istruzioni: appunti su una definizione del restauro architettonico", In: Palladio: rivista di storia dell'architettura $e$ restauro, n. 24, 1999, pp. 81-88.

. II restauro dell'architettura, l'architettura del restauro. Napoli: Liguori, 2005.

LACERDA, Norma. "Intervenções no bairro do Recife e no seu entorno: indagações sobre a sua legitimidade", In: Sociedade e Estado. Brasília, vol. 22, n. 3, 2007, pp. 621-646.

LE CORBUSIER. A Carta de Atenas. Tradução e introdução de Rebeca Scherer. São Paulo: Hucitec / Edusp, 1993.

LE GOFF, Jacques. História e Memória. Campinas: Ed. Unicamp, 4ª̣ ed., 1996.

LEITE, Rogério Proença. Contra-usos da cidade. Lugares e espaço público na experiência urbana contemporânea. Campinas: Ed. Unicamp; Aracaju: Ed. UFS, 2004.

LEMOS, Carlos A. C.; MORI, Victor Hugo; D'ALAMBERT, Clara C. Patrimônio: 70 anos em São Paulo. São Paulo: 9ª S.R./IPHAN, 2008.

LOWENTHAL, David. The heritage crusade and the spoils of History. Cambridge: Cambridge University Press, 1998. 
LUCHIARI, Maria Tereza Duarte Paes. "A reinvenção do patrimônio arquitetônico no consumo das cidades", In: GEOUSP - Espaço e Tempo. São Paulo, n. 17, 2005, pp. 95-106.

LUMIA, Chiara. A proposito del restauro e della conservazione. Roma: Gangemi Editore, 2003.

LYRA, Cyro Corrêa. "O novo Paço: uma obra para debates", In: Revista do Patrimônio Histórico e Artístico Nacional. Rio de Janeiro: SPHAN / Pró-Memória, n. 20, 1984, pp. 152-157.

MAGALHÃES, Aloísio. E Triunfo? A questão dos bens culturais no Brasil. Rio de Janeiro: Nova Fronteira; Brasília: SPHAN/Pró-Memória, 1980.

MARCONI, Paolo. "Conoscenza storica e progetto", In: Bollettino d'Arte, 1986, pp. 59-63.

Il restauro e l'architetto. Teoria e pratica in due secoli di dibattito. Venezia: Marsilio, 3를. ed., 2002.

. Materia e significato. La questione del restauro architettonico. RomaBari: Laterza, 2003.

MAYUMI, Lia. Monumento e autenticidade. A preservação do patrimônio arquitetônico no Brasil e no Japão. São Paulo: FAU-USP, Dissertação de Mestrado, 1999.

Taipa, canela preta e concreto. Um estudo sobre a restauração de casas bandeiristas em São Paulo. São Paulo, FAU-USP, Tese de Doutorado, 2005.

MENESES, Ulpiano Toledo Bezerra de. "A História, cativa da memória? Para um mapeamento da memória no campo das Ciências Sociais", In: Revista do Instituto de Estudos Brasileiros, São Paulo, n. 34, 1992, pp. 9-24.

. "Patrimônio Ambiental Urbano: do lugar comum ao lugar de todos", In: CJ Arquitetura - Patrimônio Cultural de São Paulo, n. 19, 1978, pp. 45-46.

MIARELLI MARIANI, Gaetano. Centri storici. Note sul tema. Roma: Bonsignori Editore, 1993.

MICELI, Sergio. "SPAHN: refrigério da cultura oficial" In: Revista do Patrimônio Histórico e Artístico Nacional. Rio de Janeiro: SPHAN/Pró-Memória, n. 22, 1987, pp. 44-47.

MILET, Vera. A teimosia das pedras. Um estudo sobre a preservação ambiental no Brasil. Olinda: Prefeitura de Olinda, 1988.

MORENO-NAVARRO, Antoni González. Conservació preventiva: última etapa. Memòria SPAL 1999-2001. Barcelona: Diputació de Barcelona, Xarxa de Municipis, Àrea d'Infraestructures, Urbanisme i Habitatge, Servei de Patrimoni Arquitectònic Local, 2006. 
MORI, Victor Hugo. "A História do Restauro da Barra Grande: de Lúcio Costa à participação de todos", In: Leopoldianum - Revista de Estudos e Comunicações da Universidade Católica de Santos, n. 64, volume XXIII, agosto 1997.

MORI, Victor Hugo; SOUZA, Marise Campos de; BASTOS, Rossano Lopes; GALLO, Haroldo (orgs.). Patrimônio: atualizando o debate. São Paulo: 9․ SR/IPHAN, 2006.

MORRIS, William. "The Manifesto of the SPAB", disponivel em: http://www.spab.org.uk/what-is-spab-/the-manifesto/. Acesso em: 26 nov. 2009, 17:29.

MOTTA, Lia. "A Sphan em Ouro Preto: uma história de conceitos e critérios". In: Revista do Patrimônio Histórico e Artístico Nacional. Rio de Janeiro: SPHAN / Pró-Memória, n. 22, 1987, pp. 108-122.

MUMFORD, Eric. The CIAM discourse on urbanism, 1928-1960. Cambridge: MIT Press, 2002.

Ofício das Paneleiras de Goiabeiras. Dossiê IPHAN n. 3, Brasília, DF: IPHAN, 2006.

OLIVEIRA, Almir Félix Batista de. "O IPHAN e o seu papel na construção/ampliação do conceito de patrimônio histórico/cultural no Brasil", In: Cadernos do CEOM - Bens culturais e ambientais, ano 21, n. 29 , pp. 20-38.

OLIVEIRA, Raíssa Pereira Cintra de. Permanência e inovação: o antigo e o novo nos projetos urbanos de Lina Bo Bardi. São Paulo, FAU-USP, Dissertação de Mestrado, 2008.

PALMIERI, Antonella (a cura di). Restauro e progetto. Napoli: Electa, 1991.

PANE, Roberto. "Conférence introductive", In: Le monument pour I'homme. Actes du II Congrès International de la Restauration. Venezia: ICOMOS, 1964.

PARICIO, Ignacio. "No lo conocerás bastante. La exigente intervención en el legado construido", In: Arquitectura Viva, n. 110, 2006, pp. 32-37.

PHILIPPOT, Paul. "Le problème de l'intégration des lacunes dans la restauration des peintures", In: Bulletin de l'Institut Royal du Patrimoine Artistique, n. II, 1959, pp. 5-19.

. Saggi sul restauro e dintorni. Antologia. Roma: Bonsignori Editore, 1998.

PINHEIRO, Maria Lucia Bressan. "A História da Arquitetura Brasileira e a Preservação do Patrimônio Cultural", In: Revista CPC, São Paulo, v.1, n.1, nov. 2005/abr. 2006, pp. 41-74.

. "William Morris e a SPAB", In: Rotunda, Campinas, n. 3, outubro 2004, pp. 22-35. 
Neocolonial, modernismo e preservação do patrimônio no debate cultural dos anos 1920 no Brasil. São Paulo, FAU-USP, Textos para realização do Concurso de Livre-Docência, 2005.

PIRES, Maria Coeli Simões. Da proteção ao patrimônio cultural: o tombamento como principal instituto. Belo Horizonte: Del Rey, 1994.

PONTUAL, Virgínia. "Práticas urbanísticas em áreas históricas: o Bairro do Recife", In: Revista Bibliográfica de Geografía y Ciencias Sociales (Serie documental de Geo Crítica). Universidad de Barcelona, vol. XII, n. 752, 5 de octubre de 2007.

POULOT, Dominique. Uma história do patrimônio no Ocidente, séculos XVIII$X X I$. Do monumento aos valores. São Paulo: Estação Liberdade, 2009.

PRATA, Juliana Mendes. Patrimônio cultural e cidade: práticas de preservação em São Paulo. São Paulo, FAUUSP, Tese de Doutorado, 2009.

Proteção e revitalização do patrimônio cultural no Brasil: uma trajetória. Brasília: SPHAN/Pró-Memória, 1980. Versão eletrônica disponível em: http://portal.jphan.gov.br.

Revista do Patrimônio - Cidadania. Rio de Janeiro: IPHAN, n. 24, 1996.

Revista do Patrimônio Histórico e Artístico Nacional. Rio de Janeiro: SPHAN / Pró-Memória, n. 20, 1984.

Revista do Patrimônio Histórico e Artístico Nacional. Rio de Janeiro: SPHAN / Pró-Memória, n. 21, 1986.

Revista do Patrimônio Histórico e Artístico Nacional. Rio de Janeiro: SPHAN / Pró-Memória, n. 22, 1987.

RIEGL, Aloïs. Le culte moderne des monuments. Son essence et sa genèse. Paris: Seuil, 1984.

Rivista AR - Bimestrale dell'Ordine degli Architetti di Roma e provincia, n. 60, luglio-agosto 2005.

RODRIGUES, Marly. Imagens do Passado. A instituição do patrimônio em São Paulo, 1969-1987. São Paulo: Ed. Unesp / Imprensa Oficial / Condephaat / Fapesp, 2000.

ROGERS, Ernesto Nathan.; SERT, Josep Lluís; TYRWHITT, Jaqueline. (a cura di). Il cuore della città. Per una vita più umana delle comunità. Milano: Hoelpi, 1954.

RUBINO, Silvana. "O mapa do Brasil passado", In: Revista do Patrimônio Cidadania. Rio de Janeiro: IPHAN, 1996, n. 24, pp. 96-105.

. As fachadas da história: os antecedentes, a criação e os trabalhos do Serviço do Patrimônio Histórico e Artístico Nacional, 1937-1968. Campinas/SP, IFCH-UNICAMP, Dissertação de Mestrado, 1991. 
RUSKIN, John. A lâmpada da memória. Tradução e apresentação de Maria Lucia Bressan Pinheiro. Cotia-SP: Ateliê Editorial, 2008.

SAIA, Luís. "Até os 35 anos, a Fase Heróica", In: CJ Arquitetura, n. 14, 1977, pp. $17-21$.

. Morada Paulista. São Paulo: Ed. Perspectiva, 1978.

Salvaguarda do Patrimônio - Ouro Preto/MG. Brasília: IPHAN / Programa Monumenta, Coleção Preservação e Desenvolvimento, vol. 12, 2008.

SANT'ANNA, Márcia. "A cidade-atração. Patrimônio e valorização de áreas centrais no Brasil dos anos 90", In: FERNANDES, Ana; JACQUES, Paola Berenstein (orgs.). Cadernos PPG-AU/FAUFBA - Territórios urbanos e políticas culturais. Salvador: PPG-AU/FAUFBA, número especial, ano 2, 2004, pp. 43-58.

"A face imaterial do patrimônio cultural: os novos instrumentos de reconhecimento e valorização", In: ABREU, Regina \& CHAGAS, Mário (orgs). Memória e patrimônio: ensaios contemporâneos. Rio de Janeiro: Lamparina, $2^{\mathrm{a}}$ ed., 2009, pp. 49-58.

A cidade-atração. A Norma de preservação de centros urbanos no Brasil dos anos 90. Salvador, FAU-UFBa, Tese de Doutorado, 2004.

. Da cidade-monumento à cidade-documento. A Trajetória da Norma de Preservação de Áreas Urbanas no Brasil (1937-1990). Salvador, FAU-UFBa, Dissertação de Mestrado, 1995.

SANTORO, Lucio. "Il contributo italiano alla definizione concettuale e metodologia del restauro", In: Restauro. Quaderni di restauro dei monumenti e di urbanistica dei centri antichi, n. 43, 1979, pp. 5-76.

SANTOS, Angelo Oswaldo de Araújo. "Restaura-se o Patrimônio", In: Revista do Patrimônio Histórico e Artístico Nacional. Rio de Janeiro: SPHAN / Pró-Memória, n. 22, 1987, pp. 37-39.

SANTOS, Cecília Helena Godoy Rodrigues dos. Mapeando os lugares do esquecimento: idéias e práticas na origem da preservação do patrimônio no Brasil. São Paulo, FAU-USP, Tese de Doutorado, 2007.

SANTOS, Mariza Veloso Motta. "Nasce a Academia SPHAN", In: Revista do Patrimônio - Cidadania. Rio de Janeiro: IPHAN, 1996, n. 24, pp. 7795.

. O tecido do tempo: a idéia de patrimônio cultural no Brasil, 19201970. Brasília, UnB, Tese de Doutorado, 1992.

SCARROCCHIA, Sandro. Alois Riegl: Teoria e prassi della conservazione dei monumenti. Bologna: Accademia Clementina di Bologna, 1995.

SCHNEIDER, Simone Marafon. Cultura é desenvolvimento: um panorama da atuação do BNDES em projetos de restauro (1997-2007). Rio de Janeiro: CPDOC/PPGHPBC/FGV, Dissertação de Mestrado, 2008. 
SETTE, Maria Piera. "Profilo storico", In: CARBONARA, Giovanni (diretto da). Trattato di Restauro Architettonico. Torino: UTET, 1996, vol. 1, pp. 111-291.

SORKIN, Michael (Ed.). Variaciones sobre un parque temático. La nueva ciudad americana y el fin del espacio público. Barcelona: Gustavo Gili, 2004.

SOUZA, Vladimir Alves. "La restauration des monuments au Brésil", In: Le monument pour l'homme. Actes du II Congrès International de la Restauration. Venezia: ICOMOS, 1964.

TADDEI NETO, Pedro. "Preservação sustentada de sítios históricos: a experiência do Programa Monumenta", In: Políticas culturais para 0 desenvolvimento: uma base de dados para a cultura. Brasília: UNESCO Brasil, 2003, pp. 105-115.

TORRACA, Giorgio. La cura dei materiali nel restauro dei monumenti. A cura di Maria Piera Sette. Roma: Bonsignori, 2001.

TORSELLO, B. Paolo et alli. Che cos'è il restauro?. Nove studiosi a confronto. Venezia: Marsilio, 2005.

TORSELLO, B. Paolo. "La dialettica restauro/progetto", In: Ananke. Cultura, storia e tecniche della conservazione. Firenze: Alinea, n. 19, settembre 1997, pp. 29-33.

Restauro architettonico. Padri, teorie, immagini. Milano: Franco Angeli, $7^{\mathrm{a}}$ edizione, 2001.

VARGAS, Heliana Comin; CASTILHO, Ana Luisa Howard de (orgs.). Intervenções em centros urbanos. Objetivos, estratégias e resultados. São Paulo: Manole, 2006.

VASSALLO, Eugenio. "Eugène Emmanuel Viollet-le-Duc", In: CASIELLO, Stella (a cura di). La cultura del restauro. Teorie e fondatori. Venezia: Marsilio, $3^{\text {a }}$ ed., 2005, pp. 69-93.

VIOLLET-LE-DUC, Eugène Emmanuel. Restauração. Cotia-SP: Ateliê Editorial, 2000 